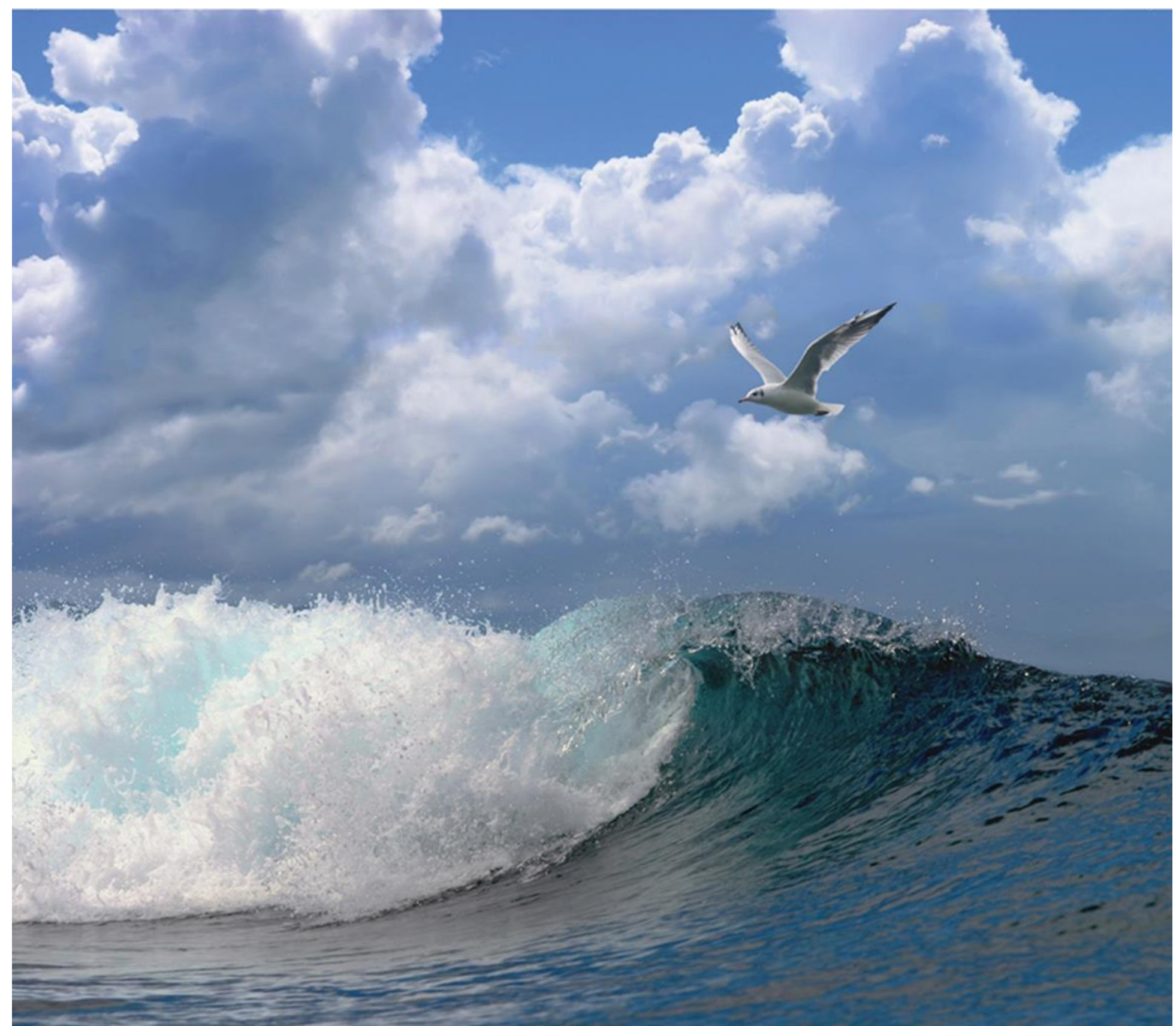

\title{
Bodemdiergemeenschap van de vooroever en het natte strand van de Zandmotor in het najaar van 2019
}

Data rapport 


\section{Bodemdiergemeenschap van de vooroever en het natte strand van de Zandmotor in het najaar van 2019}

Datarapport

Auteur(s): $\quad$ Jeroen Wijsman, Douwe van den Ende en Emiel Brummelhuis 
Keywords: Macrobenthos, Van Veen, Bodemschaaf, clusteranalyse, sedimentsamenstelling, strandbemonstering

Opdrachtgever: Rijkswaterstaat WVL

T.a.v.: Petra Damsma

Postbus 2232

3500 GE Utrecht

Dit rapport is gratis te downloaden van https://doi.org/10.18174/531836

Wageningen Marine Research verstrekt geen gedrukte exemplaren van rapporten.

Wageningen Marine Research is ISO 9001:2015 gecertificeerd.

Foto omslag: Jeroen Wijsman

\section{(c) Wageningen Marine Research}

Wageningen Marine Research, instituut binnen de rechtspersoon Stichting

Wageningen Research, hierbij vertegenwoordigd door Dr. M.C.Th. Scholten, Algemeen directeur

KvK nr. 09098104,

WMR BTW nr. NL 8113.83.696.B16.

Code BIC/SWIFT address: RABONL2U

IBAN code: NL 73 RABO 0373599285
Wageningen Marine Research aanvaardt geen aansprakelijkheid voor gevolgschade, noch voor schade welke voortvloeit uit toepassingen van de resultaten van werkzaamheden of andere gegevens verkregen van Wageningen Marine Research. Opdrachtgever vrijwaart Wageningen Marine Research van aanspraken van derden in verband met deze toepassing.

Alle rechten voorbehouden. Niets uit deze uitgave mag weergegeven en/of gepubliceerd worden, gefotokopieerd of op enige andere manier gebruikt worden zonder schriftelijke toestemming van de uitgever of auteur. 


\section{Inhoud}

$\begin{array}{lr}\text { Samenvatting } & \mathbf{5}\end{array}$

$1 \quad$ Inleiding $\quad 7$

$\begin{array}{lll}1.1 & \text { Achtergrond } & 7\end{array}$

1.2 Aanpak 1

$\begin{array}{ll}1.3 & \text { Doelstelling }\end{array}$

1.4 Dankwoord 9

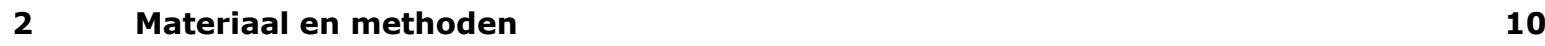

2.1 Opzet monitoring $\quad 10$

$\begin{array}{ll}2.2 \text { Weerscondities tijdens de bemonstering } & 15\end{array}$

$\begin{array}{ll}2.3 & \text { Sedimentsamenstelling } \\ 2.46\end{array}$

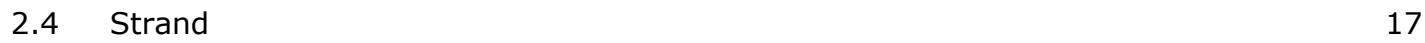

2.4.1 Bemonstering $\quad 17$

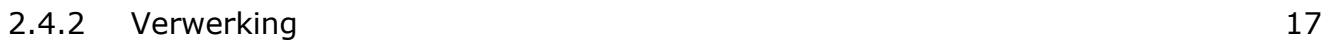

$\begin{array}{llr}2.5 & \text { Bodemschaaf } & 17\end{array}$

$\begin{array}{lll}2.5 .1 & \text { Bemonstering } & 17\end{array}$

$\begin{array}{ll}2.5 .2 \text { Verwerking } & 19\end{array}$

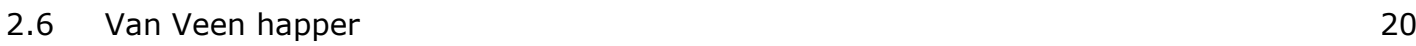

2.6.1 Bemonstering 20

$\begin{array}{ll}2.6 .2 & \text { Verwerking }\end{array}$

$\begin{array}{lll}2.7 & \text { Data analyse } & 21\end{array}$

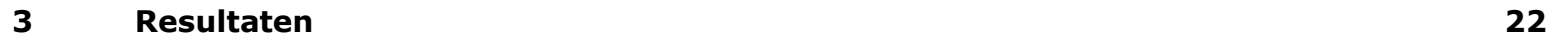

$\begin{array}{llr}3.1 & \text { Sediment } & 22\end{array}$

3.1.1 Korrelgrootteverdeling $\quad 22$

3.1.2 Vergelijk met voorgaande Jaren $\quad 25$

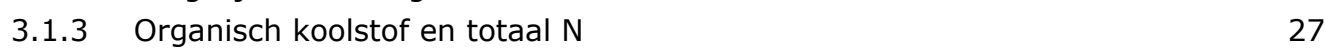

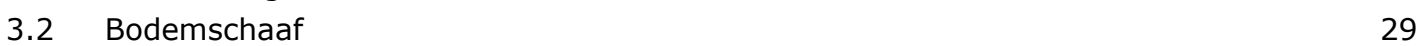

$\begin{array}{lll}3.2 .1 & \text { Overzicht } & 29\end{array}$

3.2.2 Relatie met waterdiepte $\quad 34$

$\begin{array}{lll}3.2 .3 & \text { Relatie met sedimentsamenstelling } & 37\end{array}$

$\begin{array}{lll}3.2 .4 & \text { Ruimtelijke verspreiding } & 38\end{array}$

$\begin{array}{lll}3.2 .5 & \text { Gemeenschapsanalyses } & 40\end{array}$

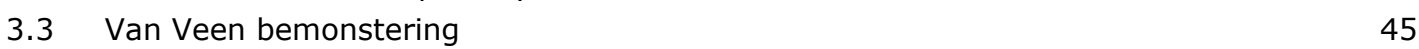

3.3.1 Overzicht $\quad 45$

$\begin{array}{lll}3.3 .2 & \text { Relatie met waterdiepte } & 49\end{array}$

3.3.3 Relatie met sedimentsamenstelling $\quad 51$

$\begin{array}{lll}3.3 .4 & \text { Ruimtelijke verspreiding } & 52\end{array}$

3.3.5 Gemeenschapsanalyses $\quad 56$

$\begin{array}{lll}3.4 & \text { Strandbemonstering } & 60\end{array}$

$\begin{array}{lll}3.4 .1 & \text { Overzicht } & 60\end{array}$

3.4.2 Relatie met droogval $\quad 62$

$\begin{array}{lll}3.4 .3 & \text { Ruimtelijke verspreiding } & 63\end{array}$

$4 \quad$ Conclusies en discussie $\quad 64$

$\begin{array}{llr}5 & \text { Kwaliteitsborging } & 66\end{array}$ 
Bijlage 1 Bemonsteringslocaties bodemschaaf

Bijlage 2 Bemonsteringslocaties Van Veen monsters

Bijlage 3 Bemonsteringslocaties Strand

76

Bijlage 4 Correcties taxa Van Veen en strand

78

$\begin{array}{llr}\text { Bijlage } 5 & \mathbf{8 0}\end{array}$

Bijlage $6 \quad$ Verspreiding van enkele bodemdiersoorten uit de schaaf 87

Bijlage $7 \quad$ Clusteranalyse bodemschaaf voorgaande jaren 94

Bijlage $8 \quad$ Verspreiding van enkele bodemdiersoorten uit de Van Veen 99 


\section{Samenvatting}

In 2011 is er een grootschalige strandsuppletie (Zandmotor) van 21.5 miljoen $\mathrm{m}^{3}$ uitgevoerd aan de Hollandse kust tussen Ter Heijde en Kijkduin. De Zandmotor wordt gezien als een mogelijk alternatief voor de kleinere, reguliere strand- en vooroeversuppleties. Het doel van dit experiment is na te gaan of het eenmalig aanbrengen van een grote hoeveelheid zand uiteindelijk goedkoper, effectiever en natuurvriendelijker is dan het herhaaldelijk aanbrengen van kleinere hoeveelheden zoals gebeurt bij de reguliere vooroever- en strandsuppleties. Om dit in kaart te brengen is in 2010 een grootschalig monitoringsprogramma opgezet. Een van de onderwerpen binnen het monitoringsprogramma is het volgen van de ontwikkeling van de bodemdiergemeenschap in de vooroever en het natte strand. Hiervoor zijn in het najaar van 2010, 2012, 2013, 2015, 2017 en 2019 sediment en bodemdiermonsters verzameld en geanalyseerd. Deze rapportage betreft de bemonstering die is uitgevoerd in het najaar van 2019.

Van 16 september tot en met 3 oktober 2019 zijn er bemonsteringen uitgevoerd van de bodemdiergemeenschap en sedimentkarakteristieken op en rond de Zandmotor. In totaal zijn er 117 stations in de vooroever bemonsterd met een Van Veen happer en 113 met de bodemschaaf. Tevens zijn er 70 stations bemonsterd op het strand tussen de hoog- en laagwater lijn. Aanvullend zijn er 326 sedimentmonsters genomen, deels op de stations waar ook bodemdieren zijn bemonsterd (187 stations), en deels op tussenliggende transecten (139 stations). De bemonsterde stations liggen op 12 parallelle transecten loodrecht op de voormalige kustlijn met een onderlinge afstand van 800 tot 1000 meter.

In voorliggende rapportage worden de resultaten van de resultaten van de analyses op sedimentsamenstelling (korrelgrootteverdeling en organisch stofgehalte) en bodemdiergemeenschap gepresenteerd en vergeleken met voorgaande jaren (2010, 2012, 2013, 2015 en 2017).

Er zijn duidelijke ruimtelijke patronen in sedimentsamenstelling met gebieden waar het sediment relatief grof is (kop van de Zandmotor en het meest noordelijk deel van onderzoeksgebied) en gebieden waar het sediment fijner is (net ten noorden en ten zuiden van de Zandmotor en in het meest zuidelijke deel van het onderzoeksgebied). Deels zijn deze patronen het directe gevolg van de Zandmotor.

De gemiddelde biomassa aan bodemdieren (met weglating van Ensis spp., strandgapers, otterschelpen en heremietkreeften) in de bodemschaaf in 2019 ( 75 gram versgewicht $\mathrm{m}^{-2}$ ) is iets minder dan in 2017 (84.5 $\mathrm{g} \mathrm{m}^{-2}$ ) maar aanzienlijk hoger dan in de jaren 2010, 2012, 2013 en 2015 (respectievelijk 1, 23 en 14 gram versgewicht $\mathrm{m}^{-2}$ ). Het gemiddeld aantal taxa per monster was 7.8. dit is hoger dan in alle voorgaande jaren. De halfgeknote strandschelp (Spisula subtruncata) en witte dunschaal ( $A b r a$ alba), nonnetje (Limecola balthica) en zaagje (Donax vittatus) waren de meest dominante soorten in de bodemschaaf met gemiddelde dichtheden van respectievelijk 93, 52, 13 en 13 individuen $\mathrm{m}^{-2}$. Opvallende nieuwkomer in de observaties van 2019 is de Amerikaanse strandschelp (Mulinia lateralis). Deze exoot is in 2017 voor het eerst aangetroffen in de Voordelta en is in 2019 al op ruim $20 \%$ van de bemonsterde locaties aangetroffen.

In de Van Veen bemonstering zijn gemiddeld meer taxa aangetroffen (in 2019, 15.5 taxa per monster) dan in de bodemschaaf. Dit komt door de fijnere maaswijdte van de zeef bij de Van Veen bemonstering $(1 \mathrm{~mm})$ ten opzichte van de bodemschaaf $(5 \mathrm{~mm})$. In het najaar van 2019 zijn er relatief veel zaagjes (Donax vittatus), tweetandschelpjes (Kurtiella bidentata), halfgeknotte strandschelpen (Spisula subtruncata), witte dunschaal (Abra alba) en gewone zandzagers (Nephtys hombergii) aangetroffen in het onderzoeksgebied.

Het totale bestand aan bodemdieren (dichtheid, biomassa en aantal soorten) neemt toe met de waterdiepte. Vooral de ondiepe zone (tot en met -5 meter NAP) is arm en wordt gekenmerkt door 
specifieke soorten zoals de breedpootkrab (Portumnus latipes) en de gemshorenworm (Scolelepis (Scolelepis) squamata). Op grotere diepten (dieper dan -6 m NAP) neemt de dichtheid, biomassa en het aantal soorten per monster sterk toe, met de hoogste waarden op dieptes groter dan $11 \mathrm{~m}$.

De Zandmotor heeft geleid tot een ruimtelijke verdeling van de bodemdiergemeenschap in het onderzoeksgebied. Dit is waarschijnlijk het directe gevolg van de veranderde hydro- en morfodynamiek. Sinds de aanleg van de Zandmotor heeft de bodemdiergemeenschap zich ontwikkeld, niet alleen in het suppletiegebied, maar ook in de gebieden ten noorden en ten zuiden van de Zandmotor. Zolang de Zandmotor de hydrodynamische en morfologische processen blijft beïnvloeden is de verwachting dat de bodemdiergemeenschap niet zal terugkeren naar de situatie van voor de aanleg. 


\section{$1 \quad$ Inleiding}

\section{$1.1 \quad$ Achtergrond}

Tussen maart en oktober 2011 is er in opdracht van Rijkswaterstaat en de Provincie Zuid-Holland een grootschalige strandsuppletie aangelegd tussen Ter Heijde en Kijkduin, de Zandmotor. De Zandmotor is aangelegd als een schiereiland in de vorm van een haak. Voor de aanleg is ongeveer 21.5 miljoen $\mathrm{m}^{3}$ (volumes in het beun) zand gebruikt, waarvan 19 miljoen $\mathrm{m}^{3}$ is gebruikt voor de aanleg van de haak en de rest voor additionele vooroeversuppleties ten noorden en ten zuiden van de zandhaak. Bij aanleg stak de Zandmotor $1.5 \mathrm{~km}$ de zee in en was aan het strand $2 \mathrm{~km}$ breed. De Zandmotor is het eerste experiment met een zogenaamde megasuppletie.

Het idee is dat de Zandmotor langzaam erodeert door wind, golven en getijdenbeweging en dat het zand de kustlijn ten noorden van de Zandmotor versterkt. De Zandmotor is een alternatief voor strand- en vooroeversuppleties die iedere 4-5 jaar dienen te worden herhaald. De doelstelling van dit experiment is om na te gaan of het eenmalig aanbrengen van een grote hoeveelheid zand uiteindelijk goedkoper, effectiever en natuurvriendelijker is dan het herhaaldelijk aanbrengen van kleinere hoeveelheden zoals gebeurt bij de reguliere vooroever- en strandsuppleties. Daarnaast is de vraag of een suppletie in deze vorm een aanwinst vormt voor de recreatie.

Het project Monitoring en Evaluatie Zandmotor is opgestart om de ontwikkelingen op en rond de Zandmotor te volgen en hier kennis en ervaring uit op te doen. Uitgangspunt van de monitoring zijn de drie hoofddoelstellingen van de MER (Fiselier, 2010):

- $\quad$ MER 1: Het stimuleren van natuurlijke duinaangroei in het kustgebied tussen Hoek van Holland en Scheveningen voor veiligheid, natuur en recreatie;

- $\quad$ MER 2: Het genereren van kennisontwikkeling en innovatie om de vraag te beantwoorden in welke mate kustonderhoud meerwaarde voor recreatie en natuur kan opleveren;

- MER 3: Het toevoegen van aantrekkelijk recreatie- en natuurgebied aan de Delflandse Kust.

Aanvullend doel van de monitoring is het vergaren van voldoende en adequate informatie om de Zandmotor en omgeving op een goede wijze te kunnen beheren (Ebbens en Fiselier, 2010). Voorliggend meetrapport richt zich op de ontwikkeling van het benthos van de vooroever en het intergetijdenstrand van de Zandmotor, en daarmee op invulling van MER 2 en MER 3.

De Zandmotor kan op verschillende manieren effect hebben op de bodemdiergemeenschap op het strand en de vooroever. De verwachting is dat een Zandmotor een levensduur heeft van ca 20 jaar. Dat betekent dat bij kustsuppleties met een Zandmotor over een relatief klein oppervlak de bodemdiergemeenschap iedere 20 jaar bedekt zal worden met een dikke laag zand. Het ruimere gebied rondom de Zandmotor zal geleidelijk worden voorzien met zand dat erodeert van de Zandmotor. Aangenomen wordt dat een groter aantal normaliter in de kustzone voorkomende soorten bodemdieren om kan gaan met deze geleidelijke bedekking met zand. Bij reguliere vooroever- en strandsuppleties daarentegen wordt de bodemdiergemeenschap over een groter oppervlak iedere 4-5 jaar met een laag sediment bedekt. De verwachting was dat deze innovatieve vorm van kustsuppletie zich zal uiten in de samenstelling van de bodemdiergemeenschap waarbij er betere kansen zijn voor langlevende soorten. Daarnaast is de verwachting dat de vorm van de Zandmotor zal leiden tot een grotere diversiteit in habitats (stroomsnelheid, golfenergie en sedimentsamenstelling) dan normaliter voorkomt in het gebied. Dit kan een effect hebben op de ruimtelijke verspreiding en variatie van soorten en bodemdiergemeenschappen en op het aantal soorten in de kustzone rondom de Zandmotor. Het benthos is een belangrijke voedselbron voor hogere trofische niveaus (vogels en vis en indirect zeezoogdieren) en daarmee kunnen effecten van de Zandmotor op de 
bodemdiergemeenschap (samenstelling en biomassa) ook effect hebben op de hogere trofische niveaus.

De hoge abstracte doelen en beheerdoelstellingen zijn vertaald in meer concrete evaluatievragen (Ebbens en Fiselier, 2010). Het project Monitoring- en Evaluatie Pilot Zandmotor is erop gericht om informatie te verzamelen om de evaluatievragen te kunnen adresseren. De opzet van de monitoring is beschreven in Tonnon et al. (2011) (Fase 2, 2011 t/m 2016) en Taal et al. (2017) (Fase 3, 2017 t/m 2021). De monitoring is reeds in 2010 gestart (Fase 1) met een To meting (Tonnon en Baptist, 2011; Wijsman en Verduin, 2011). De resultaten van Fase 2 zijn geëvalueerd in een samenvattende rapportage (Taal et al., 2016a; b).

Voorliggend datarapport richt zich op de doelen en vragen die betrekking hebben op het benthos van het strand en de ondiepe kustzone van de Zandmotor. De relevante evaluatievragen behorende bij de MER doelen zijn de volgende (Taal et al., 2017):

\section{MER doel 2:}

- Evaluatievraag EF2-2: Heeft een megasuppletie als de Zandmotor een meerwaarde voor de natuur ten opzichte van reguliere suppleties? En waardoor wordt deze meerwaarde veroorzaakt?.

- Subvraag EF2-2a: Via welke mechanismen veroorzaakt de Zandmotor veranderingen in de gradiënten in sedimentsamenstelling (korrelgrootteverdeling en organisch stof gehalte) op het natte strand en de vooroever?

- Subvraag EF2-2b: Helpt het eenmalig neerleggen van een grote hoeveelheid zand om een natuurlijkere bodemdiersamenstelling in de ondiepe kustzone te krijgen in vergelijking met een regulier suppletieschema en leidt dit ook tot langer levende soorten?

\section{MER doel 3:}

- $\quad$ Evaluatievraag EF3-1b: Hoe ontwikkelt de (tijdelijke) nieuwe natuur zich in de lagune ${ }^{1}$ en op de vooroever van de Zandmotor?

- subvraag EF3-1b1: Hoe heeft de diversiteit in sedimentsamenstelling zich ontwikkeld in de lagune en de vooroever?

- subvraag EF3-1b2: Heeft de Zandmotor nieuwe habitats en meer variatie in habitats gecreëerd. Leiden deze tot hogere natuurwaarden in intergetijdegebied en ondiepe kustzone? Is dit te kwantificeren voor bodemdieren, vissen, vogels en zeezoogdieren ${ }^{2}$

- subvraag EF3-1b3: Hoe heeft de bodemdiergemeenschap zich ontwikkeld in de lagune en de vooroever?

\subsection{Aanpak}

Om de effecten van de Zandmotor op de bodemdiergemeenschap te onderzoeken, zijn er in het najaar van 2019 voor de $7^{e}$ keer bemonsteringen uitgevoerd van sediment en bodemdieren op het strand met een steekframe, in de ondiepe kustzone met een Van Veen happer en een bodemschaaf. De Van Veen happer is vooral geschikt voor het bemonsteren van de relatief kleinere (maaswijdte zeef is 1 $\mathrm{mm})$, minder zeldzame, in de bodem levende dieren. Het bemonsterde oppervlak is echter beperkt $\left(0.1 \mathrm{~m}^{2}\right)$ ten opzichte van de bemonsterde oppervlakte met de bodemschaaf (ongeveer $15 \mathrm{~m}^{2}$ ). Grotere mobiele en sedentaire, relatief zeldzame dieren, worden daarom beter bemonsterd met een bodemschaaf. Omdat er bij de bodemschaaf gebruik wordt gemaakt van een grotere maaswijdte ( 5 $\mathrm{mm}$ ) worden kleinere organismen zoals polychaeten gemist. De bemonstering met de bodemschaaf en de Van Veen happer (of een vergelijkbare methode als de boxcorer) vullen elkaar goed aan (Ens et al., 2007) en worden vaker naast elkaar gebruikt (Wijsman et al., 2014).

\footnotetext{
${ }^{1}$ Omdat de lagune niet (meer) wordt bemonsterd zullen hier geen uitspraken over kunnen worden gedaan

${ }^{2}$ Voorliggende studie richt zich op de bodemdieren. Vis en zeezoogdieren worden niet meer gemonitord in Fase 3. Vogels worden gemonitord in een andere deelstudie
} 


\subsection{Doelstelling}

Het doel van dit datarapport is een overzicht te geven van de resultaten van de bemonstering van het sediment en benthos op het strand en de ondiepe kustzone van de Zandmotor in het najaar van 2019 en een vergelijk met voorgaande jaren. Een dergelijke bemonstering is namelijk eerder uitgevoerd in 2010 (Wijsman en Verduin, 2011), 2011 (Boon en Wijsman, 2012), 2012 (Wijsman, 2014a), 2013 (Wijsman, 2014b), 2015 (Wijsman, 2016) en 2017 (Wijsman et al., 2018). Door over meerdere jaren te monitoren, kan de jaarlijkse dynamiek in bodemdiersamenstelling worden gevolgd en kan de ontwikkeling van langlevende soorten in kaart worden gebracht. De resultaten van de bemonstering zullen worden gebruikt bij de evaluatie in 2021 waarbij de bovengenoemde evaluatievragen zullen worden geadresseerd.

\subsection{Dankwoord}

Een groot aantal mensen hebben meegewerkt aan de totstandkoming van dit rapport. Allereerst willen we de bemanning van de Ye-42 en de veldmedewerkers van Wageningen Marine Research (Douwe vd Ende, Yoeri van Esch en Jetze van Zwol) voor hun inzet tijdens de bemonstering van de vooroever met de bodemschaaf en de Van Veen happer. De medewerkers van Shore hebben geholpen bij de strandbemonstering. Een groot aantal mensen van Eurofins Aquasense, Bureau Waardenburg en Wageningen Marine Research (met name Emiel Brummelhuis, Jennifer Chin, Lotte Niemeijer Wouter Suykerbuyk en Jack Perdon) zijn betrokken bij het uitzoeken en determineren van de het benthos uit de Van Veen en Strandbemonstering. De sedimentanalyses zijn uitgevoerd door Peter van Breugel van het NIOZ in Yerseke. Babeth van der Weide, Jan-Tjalling van der Wal en Margriet van Asch waren verantwoordelijk voor het databeheer bij Wageningen Marine Research. 


\section{Materiaal en methoden}

\section{$2.1 \quad$ Opzet monitoring}

Het onderzoeksgebied van de Zandmotor kan grofweg ingedeeld worden in drie gebieden (Figuur 1) Zuid: $\quad H e t$ gebied ten zuiden van de Zandmotor (transect 0 tot en met transect 4, Figuur 1). Als gevolg van het netto kustlangs transport naar het noorden was oorspronkelijk verwacht dat het zand van de Zandmotor slechts beperkt in dit gebied zal sedimenteren.

Uiteindelijk is er wel aanzanding geweest in dit gebied, voornamelijk op transect 4. Mogelijk zal de uitstralende werking van de Zandmotor leiden tot lagere stroomsnelheden in dit gebied waardoor het zal aanzanden met sediment uit het zuiden of vanuit dieper water. Reguliere suppleties zijn dan in de nabije toekomst niet nodig. Indien het gebied, ondanks de uitstralende werking van de Zandmotor blijft eroderen zal het mogelijk in de toekomst weer dienen te worden versterkt door middel van een reguliere (vooroever) suppletie. In dat geval kan het gebied worden beschouwd als een "referentiegebied".

Zandmotor: Dit is het gebied waar de Zandmotor is aangelegd (transect 5 tot en met transect 8, Figuur 1). De oorspronkelijke zeebodem is hier bedekt met een dikke laag zand dat deels permanent boven water uitsteekt. Aan de zeezijde is een sterke dieptegradiënt ontstaan en golven en stroming zorgen hier voor een dynamisch klimaat.

Noord: Het gebied ten noorden van de Zandmotor (transect 9 tot en met transect 12, Figuur 1). Als gevolg van de dominante stroomrichting naar het noorden wordt verwacht dat het meeste zand van de Zandmotor ten noorden van de Zandmotor zal worden afgezet. Verwacht wordt dat het gebied als gevolg van de Zandmotor een depositiegebied zal worden met een sterk reliëf. Als gevolg van de geleidelijke aanzanding met zand afkomstig van de Zandmotor zullen reguliere suppleties in de nabije toekomst overbodig zijn en krijgt het bodemleven de kans zich te herstellen. 


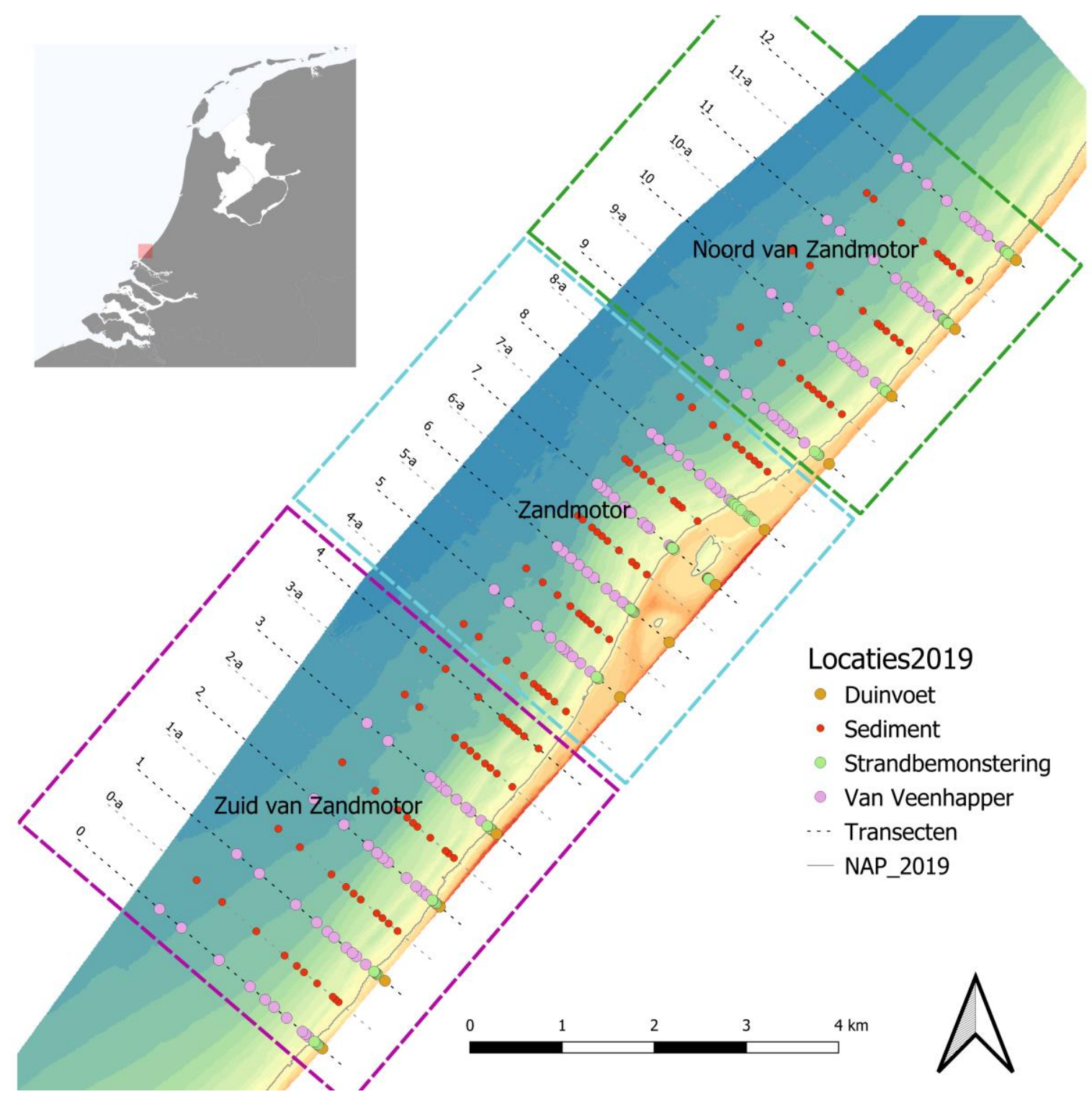

Figuur 1: Overzicht van de geplande meetlocaties voor sediment en benthos bemonstering in het najaar van 2019. De roze locaties zijn bemonsterd met de Van Veen happer en de bodemschaaf. De groene locaties lagen op het strand en zijn bemonsterd met het steekframe en op de oranje (Duinvoet) en rode locaties is uitsluitend sediment verzameld. De monsterlocaties zijn geprojecteerd op een recente dieptekaart, waarbij het gebied van de Zandmotor is gemeten in augustus 2019. De genummerde stippellijnen geven de transecten weer, loodrecht op de voormalige kustlijn. De gekleurde onderbroken kaders geven de deelgebieden weer (Zuid van Zandmotor, Zandmotor en Noord van Zandmotor).

De monitoringslocaties die in het najaar van 2019 zijn bemonsterd voor het macrobenthos liggen op 12 transecten loodrecht op de voormalige kustlijn (transecten $0,1,2,3,5,6,7,8,9,10,11$ en 12 , Figuur 1). Er is dus geen benthos bemonsterd op transect 4. De ligging van deze transecten is identiek aan de ligging van de transecten uit de bemonstering van 2013 (Wijsman, 2014b), 2015 (Wijsman, 2016) en 2017 (Wijsman et al., 2018). In 2010 (Wijsman en Verduin, 2011) en 2012 (Wijsman, 2014a) is er nog benthos bemonsterd op transect 4. Transect 0 bestond op dat moment nog niet. De reden om vanaf 2013 transect 4 te vervangen door transect 0 was dat er redelijk wat aanzanding was opgetreden op transect 4 door de aanleg van de Zandmotor waardoor dit transect niet meer kon worden beschouwd als een referentie transect. Het nieuwe transect 0 ligt verder van de Zandmotor vandaan waardoor de stations op dit transect minder zullen worden beïnvloedt door de Zandmotor. Tussen de benthos transecten zijn ook nog additionele transecten gelegen (0-a, 1-a, 2-a enz.). De bemonsterde stations op deze transecten zijn aangegeven met rode stippen (Figuur 1). Op deze additionele transecten is alleen een bodemmonster verzameld voor sedimentanalyse en is geen 
benthos verzameld. Transecten 0 tot en met 4 liggen in het gebied ten zuiden van de Zandmotor. De onderlinge afstand tussen de transecten is ongeveer 1000 meter. Transecten 4-a tot en met 8-a liggen in het gebied van de Zandmotor. De onderlinge afstand tussen deze transecten is ongeveer 800 meter. Transecten 9 tot en met 12 liggen in het invloedgebied van de Zandmotor, ten noorden van de Zandhaak. De onderlinge afstand tussen deze transecten is ongeveer 1000 meter.

In 2011, direct na de aanleg van Zandmotor, is er ook een bemonstering van de bodemdiergemeenschap uitgevoerd (Boon en Wijsman, 2012). In dat jaar is er gekozen voor een andere bemonsteringsopzet van de bodemdiergemeenschap, waarbij de transecten loodrecht op de Zandmotor zijn gelegd. Wegens de werkzaamheden zijn op de raaien 1, 2 en 3 slechts 3 van de 10 stations per raai bemonsterd met de Van Veen happer. Om budgettaire redenen zijn in 2011 slechts de helft van de bemonsterde stations uitgezocht. Bemonstering met de bodemschaaf heeft in 2011 helemaal niet plaatsgevonden. In het vergelijk tussen de jaren is daarom 2011 buiten beschouwing gelaten in voorliggend rapport.

De monsterlocaties hebben ieder een unieke code die bestaat uit het jaar en volgnummer e.g. 2019_001. De locaties 2019_001 tot en met 2019_120 zijn de locaties in de vooroever waar zowel benthos als sediment is bemonsterd. De locaties 2019_121 tot en met 2019_180 en 2019_196 tot en met 2019_205 zijn de locaties op het strand waar zowel benthos als sediment is bemonsterd. Op de locaties 2019_215 tot en met 2019_344 in de vooroever en 2019_181 tot en met 2019_192 op het strand is alleen een sedimentmonster genomen.

\section{Monsterlocaties in de vooroever}

In de vooroever van ieder transect liggen 10 monsterlocaties die zijn bemonsterd met de Van Veen happer en met de bodemschaaf. Op het eerste transect (transect 0) liggen van het strand naar het diepe water de locaties 2019_001 tot en met 2019_010. Op het tweede transect (transect 1) liggen de locaties 2019_011 tot en met 2019_020, enzovoorts (Figuur 2). De exacte ligging van de monsterlocaties op de transecten is bepaald aan de hand van een recente bathymetriekaart (augustus 2019), waarbij rekening is gehouden met de diepteligging en de morfologie. In principe zijn de diepteklassen aangehouden zoals aangegeven in Tabel 1. Indien er een brekerbank aanwezig was op het transect zijn de bemonsterde locaties zo gekozen dat er een locatie ligt op de top van de brekerbank en een locatie in de trog aan de binnenkant van de brekerbank (Figuur 2 en Figuur 3). Indien er geen (duidelijke) brekerbank aanwezig was zijn de locaties gelegen op het snijpunt van de transecten met de dieptelijnen zoals aangegeven in Tabel 1. 


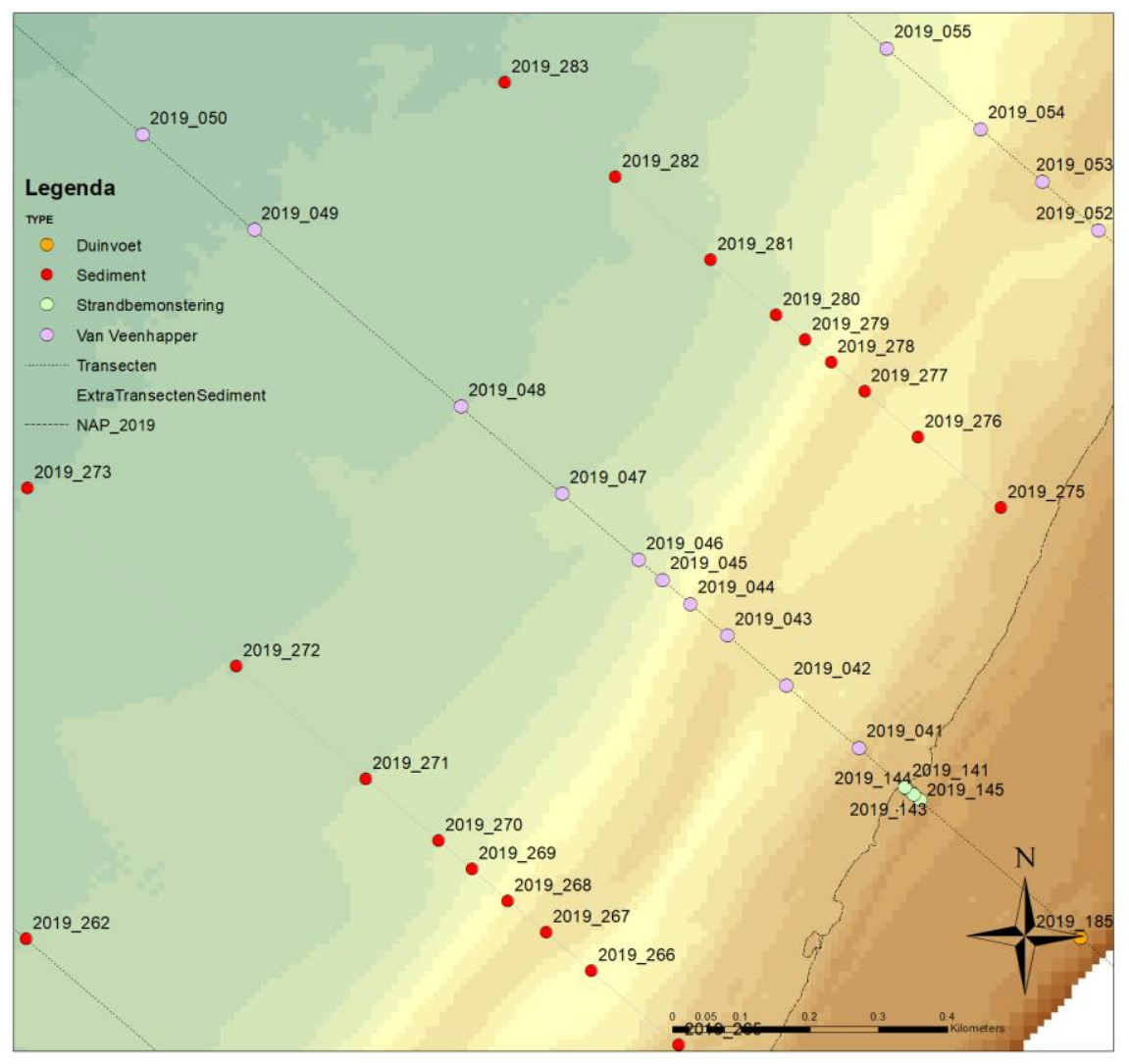

Figuur 2: Detailoverzicht van transect 5 uit de sediment en benthos bemonstering in het najaar van 2019.

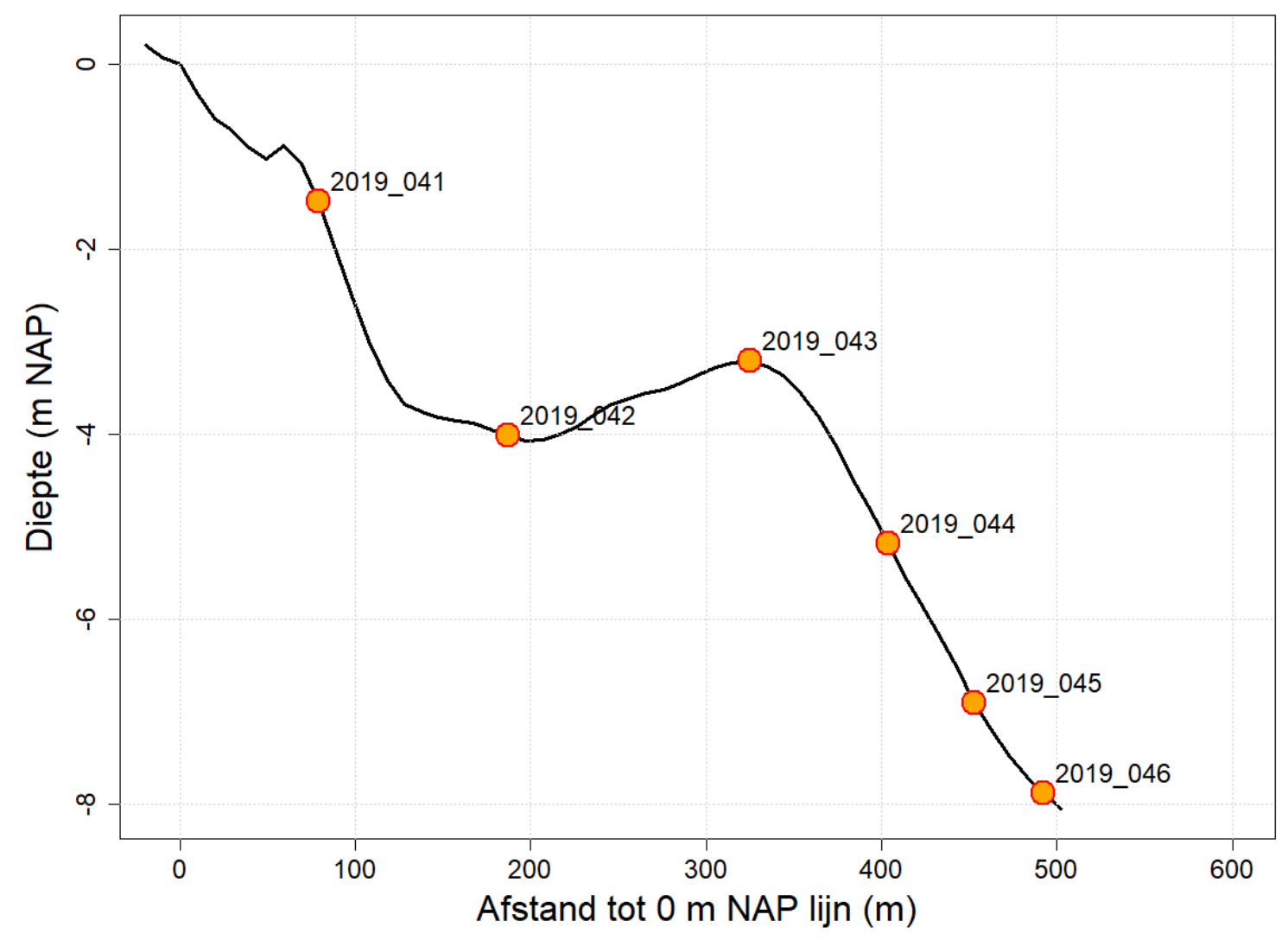

Figuur 3: Hoogteprofiel van transect 5. De oranje punten geven de bemonsterde stations weer. 
Tabel 1: Voorgenomen diepteligging ( $\mathrm{m}$ t.o.v NAP) van de monsterlocaties in de vooroever.

\begin{tabular}{lc} 
Klasse & $\begin{array}{c}\text { Diepteligging } \\
\text { (m NAP) }\end{array}$ \\
\hline 1 & -1.5 \\
\hline 2 & $-3^{1}$ \\
\hline 3 & $-4^{2}$ \\
\hline 4 & -5 \\
\hline 5 & -7 \\
\hline 6 & -8 \\
\hline 7 & -9 \\
\hline 8 & -10 \\
\hline 9 & -11 \\
\hline 10 & -11.5 \\
\hline
\end{tabular}

${ }^{1}$ Indien er een brekerbank aanwezig is, is deze monsterlocatie verplaatst naar de trog aan de binnenzijde van de brekerbank

${ }^{2}$ Indien er een brekerbank aanwezig is, is deze monsterlocatie verplaatst naar de top van de brekerbank

\section{Monsterlocaties op het strand}

Op het strand zijn telkens 5 monsterlocaties gelegen op dezelfde transecten. Op transect 0 liggen van de laagwaterlijn naar de hoogwaterlijn de locaties 2019_121 tot en met 2019_125. Op transect 1 liggen de locaties 2019_126 tot en met 2019_130, enzovoorts (Tabel 10). In het intergetijdengebied rond de lagune zijn twee aanvullende transecten bemonsterd. Op transect 8 zijn er aan de noordzijde van de lagune 5 stations bemonsterd (stations 2019_196 tot en met 2019_200). Op transect 7 zijn er aan de zuidzijde van de lagune 5 stations bemonsterd (stations 2019_201 tot en met 2019_205).

De exacte ligging van de monsterlocaties op het strand is afhankelijk van het getij. Bij Scheveningen gaat het water ongeveer 5 uur af (Figuur 4). Daarna neemt het water weer een klein beetje toe waarna het weer een beetje $(20-30 \mathrm{~cm})$ afneemt. Om de droogvalduur van de locaties per droogvalduurklasse uniform te houden zijn er iedere 1:15 uur monsters van de te bemonsteren transecten verzameld. De coördinaten van de monsterlocaties op het strand zijn geregistreerd met een handheld GPS (Garmin GPS 60).

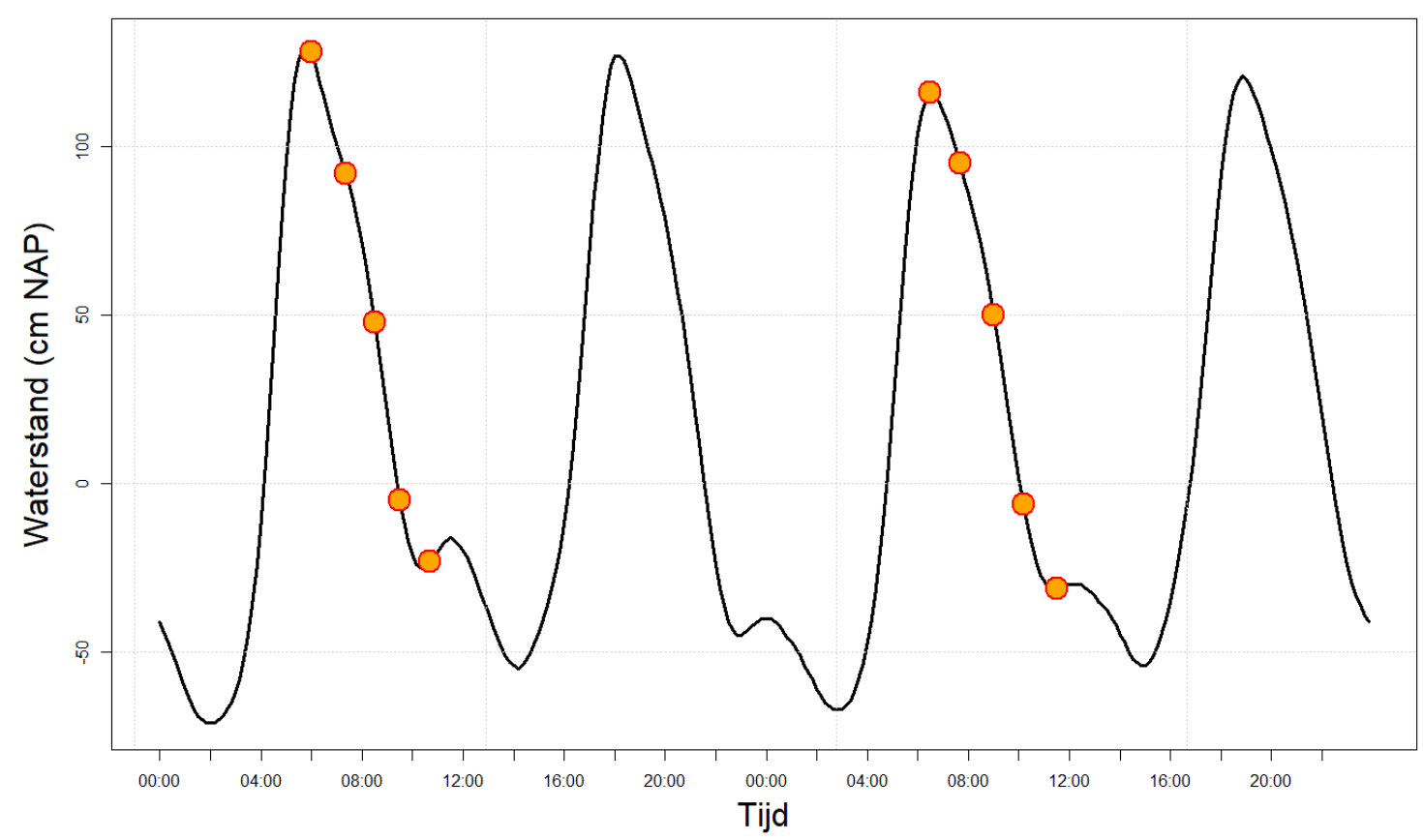

Figuur 4: Voorspelde getijcurve Scheveningen voor donderdag 3 oktober en vrijdag 4 oktober 2019. De oranje stippen geven het moment van bemonstering weer. 
Ten slotte is er op ieder transect ook nog een sedimentmonster genomen op de locatie waar het strand overgaat in het duin (Station nummers 2019_181 tot en met 2019_192). Deze zijn door middel van oranje stippen aangegeven in Figuur 1.

\subsection{Weerscondities tijdens de bemonstering}

In Figuur 5 zijn de daggemiddelde luchttemperatuur, windsnelheid en windrichting (KNMI, locatie Hoek van Holland) en de daggemiddelde golfhoogte (www.windguru.cz, locatie Ter Heijde) weergegeven voor de periode 1 augustus 2019 tot en met 1 november 2019. De periode van de veldbemonstering is in roze aangegeven. Tijdens de schaaf en van Veen bemonstering was het relatief rustig weer, met wind uit het noorden draaiend naar het oosten en golfhoogtes van minder dan 1.5 meter. Vlak voor de strandbemonstering (begin oktober) heeft het nog stevig gewaaid (windkracht 6 Bft uit het zuidwesten), waardoor de golfhoogten zijn opgelopen tot 2 meter.

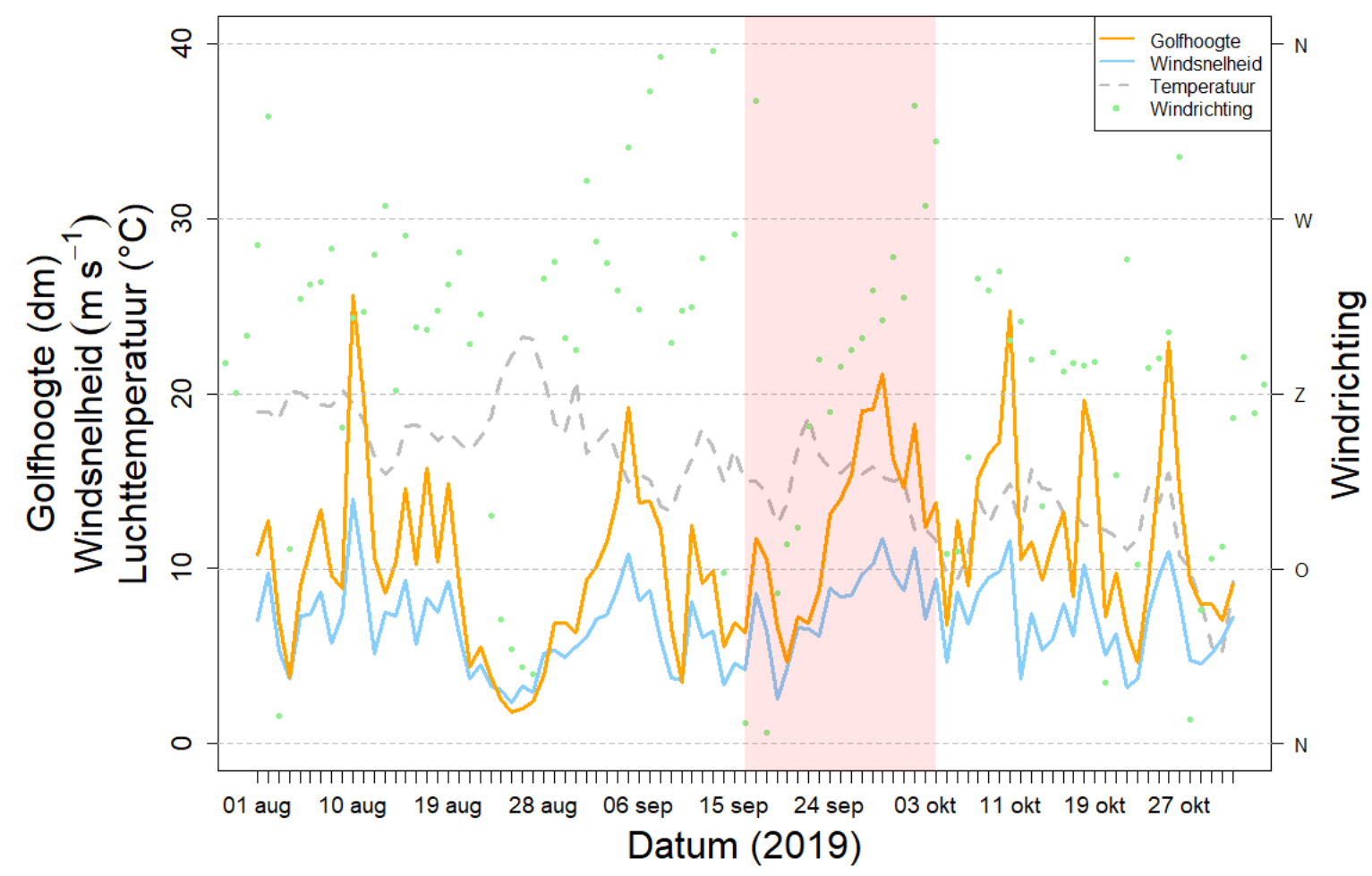

Figuur 5: Overzicht weersgegevens (Hoek van Holland) en golfhoogte (Ter Heijde) in de periode tussen 1 augustus en 1 november 2019. De oranje lijnen geven de daggemiddelde golfhoogtes (dm), de blauwe lijn de daggemiddelde windsnelheid ( $\mathrm{m} \mathrm{s}-1$ ) en de gebroken grijze lijn de luchttemperatuur $\left({ }^{\circ} \mathrm{C}\right)$. De groene stippen geven de daggemiddelde windrichting aan. De bemonsteringsperiode is aangegeven door het oranje vlak. Data zijn afkomstig van KNMI (wind en temperatuur) en windguru.cz (golfhoogte).

De overheersende windrichting bij Ter Heijde in de periode 2010 tot en met 1 november 2019 is uit het zuidwesten (Figuur 6, linker panel). In het najaar van 2019 (1 augustus tot en met 1 november) kwam de overheersende windrichting overeen met het langjarig gemiddelde. Wel is er een aantal perioden geweest waarbij de wind uit het oosten kwam. 

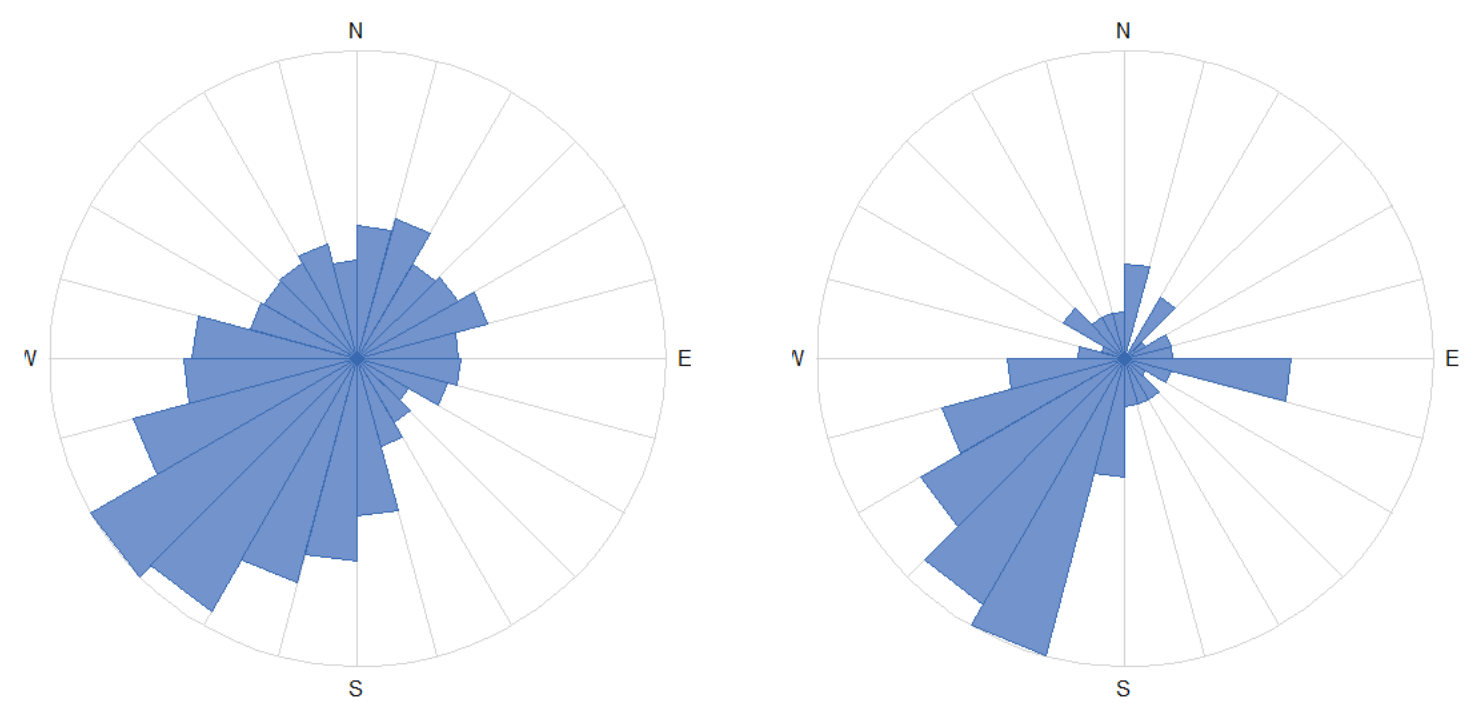

Figuur 6: Windroos voor de locatie Hoek van Holland voor de periode 1 jan 2010 tot en met 1 november 2019 (links) en voor het najaar ( 1 augustus tot en met 1 november) van 2019. Weergegeven is het aantal dagen dat de wind uit een bepaalde hoek kwam. Het maximaal aantal dagen is respectievelijk 320 en 13 dagen voor de linker en rechter figuur.

\subsection{Sedimentsamenstelling}

In de periode van 19 september tot en met 4 oktober 2019 zijn in totaal 326 sedimentmonsters genomen voor de analyse van de korrelgrootteverdeling. Van 187 van deze stations is tevens het organisch stofgehalte (fractie organisch koolstof en totaal stikstof) bepaald. 244 locaties zijn bemonsterd in de ondiepe kustzone, 70 locaties op het strand en 12 locaties aan de rand van de duinvoet. In de ondiepe kustzone is een steekbuis $(\varnothing 3 \mathrm{~cm}$ ) vijf $\mathrm{cm}$ diep in het verzamelde sediment van de Van Veen happer gestoken. Op het strand is er een sedimentmonster genomen direct naast het steekframe. Gedurende de bemonstering zijn de sedimentmonsters bewaard in een koelbox en vervolgens in het laboratorium opgeslagen bij $-32{ }^{\circ} \mathrm{C}$.

Alle 326 monsters zijn gevriesdroogd en vervolgens is een sub-sample geanalyseerd op de korrelgrootteverdeling. De korrelgrootteverdeling is geanalyseerd middels laser diffractie met een Malvern Mastersizer (detectie range $0.02-2000 \mu \mathrm{m}$ ), op het laboratorium van het NIOZ in Yerseke. Het sediment is hierbij niet voorbehandeld. De korrelgrootteverdeling is geclassificeerd in 5 verschillende fracties (Tabel 2) volgens Wentworth (1922) en de mediane korrelgrootte $(\mu \mathrm{m})$ is berekend.

\begin{tabular}{lc} 
Tabel 2: & Klassegrenzen korrelgrootteverdeling (naar Wentworth, 1922). \\
Fractie & range \\
Silt & $<63 \mu \mathrm{m}$ \\
\hline Zeer fijn zand & $62.5-125 \mu \mathrm{m}$ \\
\hline Fijn zand & $125-250 \mu \mathrm{m}$ \\
\hline Medium zand & $250-500 \mu \mathrm{m}$ \\
\hline Grof zand & $500-1000 \mu \mathrm{m}$ \\
\hline
\end{tabular}

Een deel (187) van de monsters (roze en groene punten in Figuur 1) is tevens geanalyseerd op organisch stofgehalte (total $\mathrm{N}$ en Org C) met een Carlo Erba elemental analyzer, type NA-1500. Als voorbehandeling is het monster na vriesdrogen gemaald. De analyses zijn uitgevoerd door het NIOZ in Yerseke. Van de extra stations (rode stippen in Figuur 1) en de stations aan de duinvoet (oranje stippen in Figuur 1) zijn geen organisch stofgehalten bepaald. 


\section{$2.4 \quad$ Strand}

\subsubsection{Bemonstering}

De bemonstering van het strand is door Wageningen Marine Research uitgevoerd op donderdag 3 oktober 2019 (transecten 8 tot en met 12) en vrijdag 4 oktober 2019 (transecten 0 tot en met 7)(Bijlage 3, Tabel 10). In totaal zijn er 70 locaties op het strand bemonsterd voor benthos. Er zijn twee transecten bemonsterd rond de lagune op de transecten 7 en 8 (Stations 2019_196 tot en met 2019_205). Tijdens de strandbemonstering zijn ook de (12) sedimentmonsters aan de duinvoet verzameld.

De locaties zijn bezocht met een 4WD tijdens afgaand water. Op 3 oktober was het voorspelde hoogwater bij Scheveningen om 6:47 (130 cm NAP) en laagwater om 15:10 (-55 cm NAP). Op 4 oktober was het hoogwater om 7:31 (116 cm NAP) en laagwater om 15:56 (-54 cm NAP). Zodra de locatie droog kwam te staan is er een rvs frame $\left(37 \times 27 \mathrm{~cm} \approx 0,1 \mathrm{~m}^{2}\right)$ de bodem ingedrukt tot een diepte van $13 \mathrm{~cm}$ (Figuur 7). Met een spade is de inhoud van het frame leeggeschept en in emmers overgebracht. De inhoud van de emmers is vervolgens gezeefd over een $1 \mathrm{~mm}$ zeef. Het residu dat op de zeef is achtergebleven is overgebracht in potten $(250-2500 \mathrm{ml}$ ) en geconserveerd in zeewater gebufferde formaline (4\%).

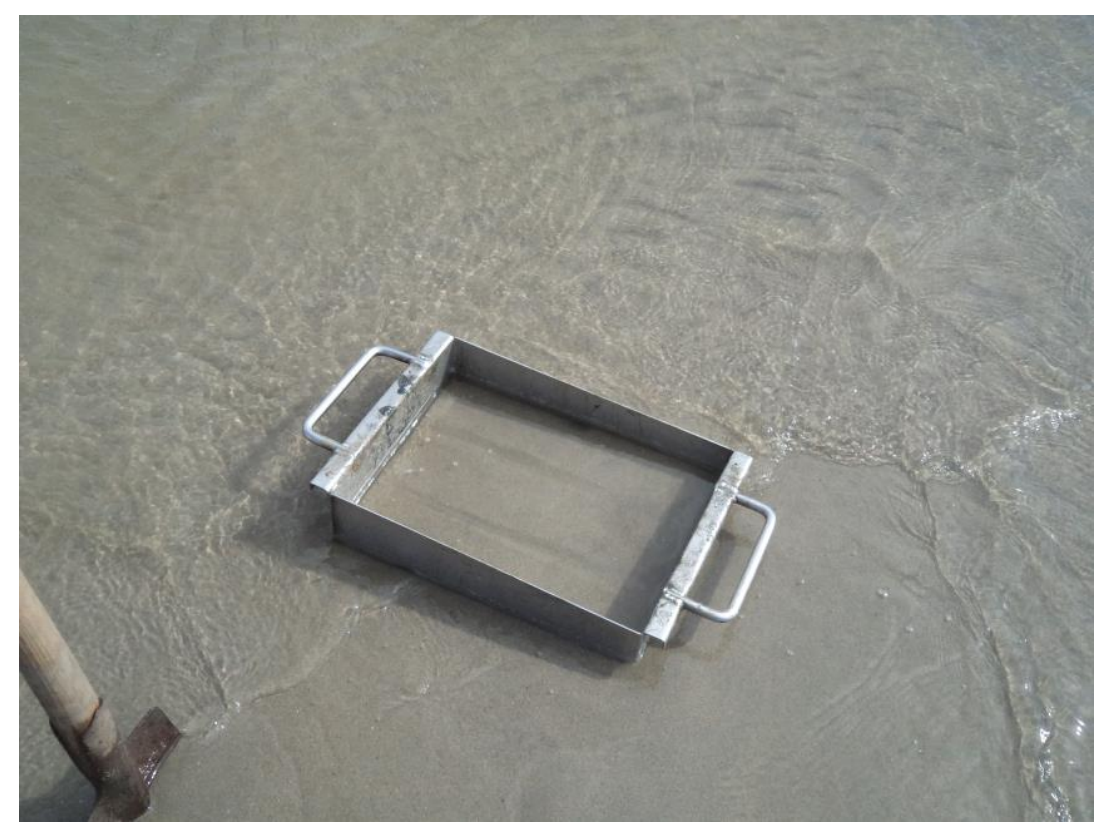

Figuur 7: $\quad$ RVS frame foor de strandbemonstering. NB op de foto is er water in het frame gestroomd. Tijdens de bemonstering zou deze opnieuw worden gestoken om te voorkomen dat bijvoorbeeld amphipoden weg kunnen zwemmen.

\subsubsection{Verwerking}

De verwerking van de benthosmonsters van het strand was identiek aan de verwerking van de Van Veen monsters. Een beschrijving is te vinden in paragraaf 2.6.2.

\section{$2.5 \quad$ Bodemschaaf}

\subsubsection{Bemonstering}

De bemonstering met de bodemschaaf is door Wageningen Marine Research uitgevoerd met de Ye-42 in de periode van 16 september tot en met 24 september 2019. De bodemschaaf wordt gebruikt voor een kwantitatieve bemonstering van de grotere en relatief zeldzame epibenthos en endobenthos soorten. De bodemschaaf is een kooi (maaswijdte $0.5 \mathrm{~cm}$ ) die aan de onderzijde is voorzien van een 
mes van $10 \mathrm{~cm}$ breed (Figuur 8). Het mes is ontworpen om een strip sediment over een bepaalde afstand tot een diepte van $10 \mathrm{~cm}$ weg te halen en in de kooi te brengen. Omdat het voorste deel iets boven de bodem hangt worden ook epibenthische organismen gevangen. Bepaalde vissen worden ook gevangen in de bodemschaaf (b.v. zandspiering), maar voor een kwantitatieve bemonstering van de vispopulaties zijn andere methodieken (bijvoorbeeld sleepnetten) meer geschikt. De kooi van de bodemschaaf fungeert tijdens het vissen als zeef. De bodemschaaf wordt achter een schip over de zeebodem getrokken. De beviste afstand wordt bepaald via een aan de zijkant van de bodemschaaf gemonteerd wiel (omtrek 1,5 meter) voorzien van een elektronische teller die het aantal omwentelingen van het wiel registreert (Figuur 8).

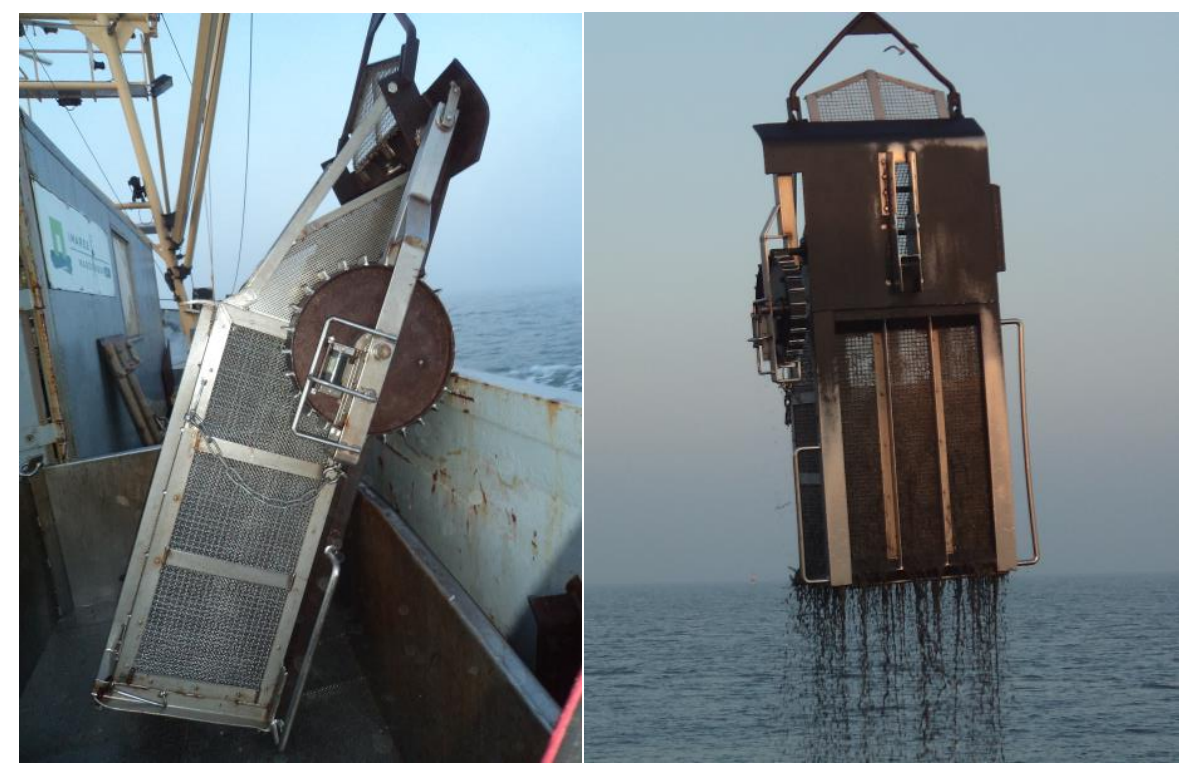

Figuur 8: Bodemschaaf. Links de bodemschaaf voordat deze overbood wordt gezet. Goed te zien is het wiel en de teller om het aantal omwentelingen te registreren waardoor de sleepafstand is te bepalen. Rechts is een gevulde bodemschaaf, voor driekwart gevuld met ruw monster. Het mes is op deze foto goed te zien.

Om te zorgen voor een goed bodemcontact is er een gewicht ( $280 \mathrm{~kg}$ ) geplaatst in het voorste deel van de bodemschaaf waar het mes zich bevindt. Om te voorkomen dat het wiel ronddraaide terwijl de bodemschaaf geen bodemcontact heeft, is een verstelbare blokkeerinrichting aangebracht. De valdiepte waarbij het wiel (inclusief schoepen) nog juist vrij kan draaien is op $90 \mathrm{~mm}$ ten opzichte van de onderkant van de bodemschaaf gezet.

De beoogde treklengte bedroeg $100 \mathrm{~m}$, resulterend in een bemonsterd oppervlakte van $10 \mathrm{~m}^{2}$. Dit is iets minder dan in 2017 om te voorkomen dat de schaaf te vol komt te zitten en dus niet goed vist. Bij iedere trek het moment van het begin en einde van vieren en halen geregistreerd en de diepte en de kabellengte genoteerd. De DGPS-positie van het schip is vastgelegd via twee onafhankelijke DGPSontvangers: Fugro Seastar DGPS met externe correctie vanaf de ARFSAT satelliet $(20 \mathrm{~Hz})$ en, als reserve, een JRC DGPS $(1 \mathrm{~Hz})$.

Alle slepen zijn genomen evenwijdig aan de kust (Figuur 9) Dit om verschillen in heterogeniteit als gevolg van een verandering in bathymetrie te beperken. Er is zoveel mogelijk gestreefd om over het vooraf bepaalde punt heen te slepen met de bodemschaaf. 


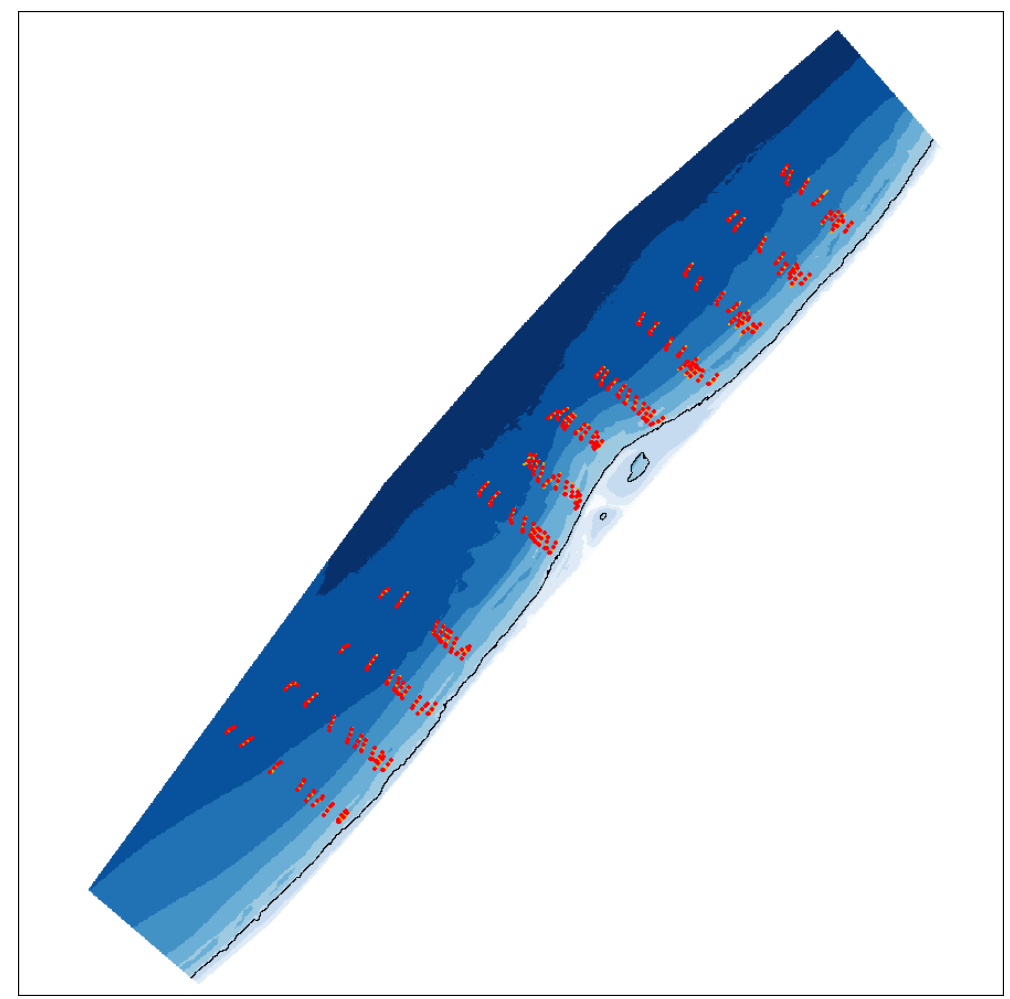

Figuur 9: Overzicht van de trekken met de bodemschaaf in 2019. De oranje lijn is de positie van het schip tijdens de sleep. De rode punten geven de momenten van begin vieren, eind vieren, begin halen en eind halen.

In verband met de ondiepte in combinatie met de golven was het niet mogelijk om alle stations te bemonsteren. In totaal konden 7 ondiepe stations (2019_001, 2019_021, 2019_031, 2019_061, 2019_091, 2019_101 en 2019_111) niet bemonsterd worden. De coördinaten van de bemonsterde stations zijn weergegeven in Tabel 8.

Ieder monster genomen met de bodemschaaf is in een bak, aan de onderzijde voorzien van gaas met een maaswijdte van $5 \mathrm{~mm}$ overgebracht en, indien noodzakelijk, is het monster gespoeld om het overtollige sediment te verwijderen. De vangst is nadien overgebracht in kisten van 48 liter of emmers van 10 liter.

\subsubsection{Verwerking}

Het totale volume van de vangst (liter) na het spoelen van het monster is genoteerd. Indien de vangst meer dan 6 liter was is er een sub-sample genomen van 6 liter welke in de container aan dek verder is gesorteerd en waar mogelijk alle dieren tot op soort gedetermineerd zijn.

Vervolgens is per soort het aantal individuen en het versgewicht (met uitzondering van de heremietkreeften (Diogenes pugilator en Pagurus bernhardus), en de otterschelp (Lutraria lutraria)). Het versgewicht is bepaald door weging op een zeeweegschaal van Marel M2000 series (weegvermogen: 0-300 gr (nauwkeurigheid $0.1 \mathrm{gr}$ ); 300-600 gr (0.2 gr); 600-1500 gr (0.5 gr)). Van otterschelpen (Lutraria lutraria), strandgapers (Mya arenaria) en zwaardschedes (Ensis spp.) worden door de bodemschaaf vaak alleen de siphonen bemonsterd. Van deze soorten konden daarom versgewicht niet direct worden bepaald.

Kapotte exemplaren van schelpdieren zijn meegeteld bij de bepaling van het aantal individuen indien a) het slot en vleesresten of b) enkel de sifons (bijv. zwaardschedes, otterschelpen) aanwezig zijn. Alle hele exemplaren van schelpdieren zijn per soort samen gewogen. Aantallen van krabben, slangsterren en zeesterren zijn bepaald aan de hand van respectievelijk het aantal carapaxen, het aantal schijven en het aantal armen ( $1 \mathrm{arm}=0.2$ individuen). De kapotte exemplaren en delen zijn ook gewogen. In tegenstelling tot de bemonstering in 2017 zijn er in 2019 geen schelplengtes 
gemeten. Ook zijn de schelpbreedtes van zwaardschedes niet gemeten waardoor het niet mogelijk is het versgewicht van deze soort te schatten.

Volledige exemplaren van vissen en garnalen zijn per individu gewogen. Tevens is per individu de lengte gemeten. Van kapotte exemplaren van vissen en garnalen zijn de koppen geteld, en meegeteld bij de bepaling van het aantal individuen. Alle restanten (incl. koppen) per soort zijn gezamenlijk gewogen (versgewicht). Niet te identificeren visresten zijn gezamenlijk gewogen.

Alle gegevens m.b.t. de aantallen en de versgewichten per soort zijn direct aan boord ingevoerd in een database. De gegevens m.b.t tellerstand en vangstvolumes zijn eerst aan dek genoteerd en op een later tijdstip in de invoerdatabase overgenomen.

Met de bodemschaaf worden naast schelpdieren, stekelhuidigen en anemonen ook een aantal mobiele vissen en garnalen gevangen. De bodemschaaf is niet ontwikkeld voor de bemonstering van deze mobiele soorten. In de verdere analyses zijn dan ook de vissen, de inktvissen en ook de garnalen buiten beschouwing gelaten. De vangstgegevens zijn wel ingevoerd in de database.

\subsection{Van Veen happer}

\subsubsection{Bemonstering}

De bemonstering van het macrozoöbenthos en het sediment in de ondiepe kustzone met de Van Veen bodemhapper is uitgevoerd met de Ye-42 op 19 september 2019. In totaal zijn er 117 van de beoogde 120 stations op één dag bemonsterd. Drie stations lagen te ondiep om te worden bemonsterd. In 2019 zijn er geen benthosmonsters genomen met de Van Veen happer in de lagune. De coördinaten van de bemonsterde stations zijn weergegeven in Bijlage 2.

De bemonstering is uitgevoerd met een verzwaarde Van Veen bodemhapper, met een oppervlakte van $0,1 \mathrm{~m}^{2}$. Op iedere locatie is één monster genomen. Wanneer de Van Veen bodemhapper niet vol zat is het monster afgekeurd en is er een nieuw monster genomen.

De totale inhoud van de Van Veen bodemhapper is gezeefd over een $1 \mathrm{~mm}$ zeef en gefixeerd op zeewater gebufferde formaldehyde (4\%). De monsters zijn gecodeerd en opgeslagen

\subsubsection{Verwerking}

Alle benthosmonsters die zijn verzameld met de Van Veen bodemhapper in de vooroever alsmede de benthosmonsters die zijn verzameld op het strand zijn uitgezocht en de aangetroffen exemplaren zijn (indien mogelijk) tot op soort gebracht door taxonomen van Wageningen Marine Research (50\% van de monsters) en het consortium Eurofins Aquasense/Bureau Waardenburg (overige 50\% van de monsters). Alle monsters die door Eurofins Aquasense/Bureau Waardenburg zijn geanalyseerd zijn door Wageningen Marine Research nagelopen, en waar nodig gecorrigeerd alvorens deze zijn verast.

Per locatie per soort is het asvrijdrooggewicht (AFDW) bepaald met een PrepAsh. Deze verassingsoven kan 12 tot maximaal 29 monsters (afhankelijk van de grootte van het monster) in een run analyseren. Tijdens het drogen en het verassen wordt het gewicht van het monster continu gemonitord. Wanneer de gewichten van de monsters tijdens het drogen respectievelijk verassen niet meer veranderen (< $0.1 \%$ per 30 minuten) is de betreffende fase afgerond. Het drogen is uitgevoerd bij $100^{\circ} \mathrm{C}$ en het verassen bij $520^{\circ} \mathrm{C}$. AFDW is bepaald uit het verschil tussen het drooggewicht en het gewicht na verassing. Omdat van de soorten Ensis, Mya arenaria en Lutraria lutraria vaak alleen de siphonen in de monsters zitten zijn deze soorten niet meegenomen in de biomassabepalingen van de Van Veen monsters.

Er zijn diverse correcties uitgevoerd op de taxa die zijn aangetroffen in de Van Veen bemonstering alvorens deze zijn geanalyseerd. Een aantal taxa zijn samengevoegd en een aantal taxa zijn verwijderd Tabel 11, Bijlage 4. De reden voor deze aanpassing is dat het voor bepaalde taxa niet 
eenvoudig is om deze tot op soort te determineren of omdat er discussie is. Deze soorten zijn dan samengebracht tot een hoger taxon niveau. Ook zijn sommige taxa op genus niveau juist tot soortsniveau gebracht (e.g. Fabulina naar Fabulina fabula), omdat kan worden verwacht dat deze tot betreffende soort behoren. Oligochaeta, Bryozoa en Hydrozoa zijn allemaal samengenomen. Vissen, insecten en pelagische wormen (Chaetognatha) zijn niet meegenomen in de analyses.

\subsection{Data analyse}

De bodemdiergegevens verzameld met de bodemschaaf en de Van Veen happer zijn afzonderlijk geanalyseerd met diverse univariate- en multivariate technieken. In de multivariate analyses van de schaafdata van 2019 zijn alleen de taxa meegenomen die op meer dan één station zijn aangetroffen. In de multivariate analyses van de Van Veen gegevens van 2019 zijn alleen de taxa meegenomen die in 2019 op 5 of meer stations zijn aangetroffen. In de multivariate analyses over alle jaren (2010 tot en met 2019) zijn voor de schaaf alleen de taxa die minimaal op 5 stations zijn aangetroffen meegenomen in de analyse. Voor de multivariate analyse van de Van Veen bemonstering over alle jaren zijn alleen de taxa meegenomen die minimaal 10 keer zijn aangetroffen. In 2013 en 2015 zijn er ook van Veen bemonsteringen uitgevoerd in de lagune. Deze monsters zijn niet meegenomen in de analyses.

De multivariate analyses (cluster analyse en multi-dimensional scaling) zijn uitgevoerd op de dichtheden (aantal $\mathrm{m}^{-2}$ ) van de organismen met behulp van PRIMER (Clarke et al., 2014a; Clarke en Gorley, 2015). De data zijn vierdemachtswortel getransformeerd om ervoor te zorgen dat er een goede balans is tussen dominante soorten en minder abundante soorten in de variantieanalyses (Clarke et al., 2014b). De analyses zijn uitgevoerd op de Bray-Curtis similariteits matrix. De BrayCurtis similariteit $\left(S_{j k}\right)$ tussen twee locaties ( $\mathrm{j}$ en $\mathrm{k}$ ) is daarbij berekend als:

$$
S_{j k}=100\left\{1-\frac{\sum_{i=1}^{p}\left|y_{i j}-y_{i k}\right|}{\sum_{i=1}^{p}\left|y_{i j}+y_{i k}\right|}\right\}
$$

Hierbij is $y_{i k}$ de dichtheid van soort $i$ op locatie $k$. Hoe hoger de waarde van de Bray-Curtis similariteit tussen twee locaties $j$ en $k$, hoe meer overeenkomsten tussen bodemdiergemeenschap die is gevonden op beide stations. De Bray-Curtis similariteit ligt tussen 0 (bodemdiersamenstelling is compleet anders) en 100 (zelfde soorten in dezelfde verhoudingen).

Een clusteranalyse groepeert de bemonsterde stations in groepen (clusters) op basis van de overeenkomsten in de bodemdiersamenstelling (Bray-Curtis similariteit). Stations binnen een cluster hebben dus een overeenkomstige bodemdiergemeenschap. De clusters zijn berekend op group averages en de significantie van de clusters is getoetst met een SIMPROF permutatietest $(\alpha=0.05)$. Met behulp van deze test is het mogelijk om te toetsen of de verschillen in bodemdiersamenstelling tussen twee verschillende cluster gebaseerd zijn op toeval of niet.

Een andere manier om de verschillen in bodemdiergemeenschap tussen de stations te visualiseren, is via multidimensional scaling (MDS). Bij een MDS worden de dissimilariteiten (100 - similariteit) gevisualiseerd in een twee-dimensionale figuur, waarbij de afstand tussen twee locaties op de figuur overeenkomt met de dissimilariteit in bodemdiersamenstelling tussen betreffende stations. Hoe dichter de stations dus bij elkaar liggen in een MDS plot, hoe meer overeenkomsten er zijn in bodemdiersamenstelling. Een nMDS is een niet-metrische MDS waarbij de afstand is gebaseerd op de rangorde van de dissimilariteiten. Om de ontwikkeling over de tijd in kaart te brengen zijn er aanvullende nMDS analyses uitgevoerd over geaggregeerde data (Jaar_Gebied en Jaar_Diepteklas). 


\section{Resultaten}

\subsection{Sediment}

\subsubsection{Korrelgrootteverdeling}

Er zijn een groot aantal sedimentkarakteristieken gemeten met de Malvern Particle Sizer (Bijlage 5, Tabel 12). Veel van deze parameters zijn aan elkaar gerelateerd. In Figuur 10 zijn deze parameters tegen elkaar uitgezet, samen met de diepte waar het monster is genomen (cm t.o.v. NAP). Uit de figuur is te zien dat veel van parameters (zeer fijn, fijn, medium en grof) sterk zijn gerelateerd aan de parameter mediane korrelgrootte. Daarom kan de mediane korrelgrootte worden gebruikt als proxy voor deze parameters.

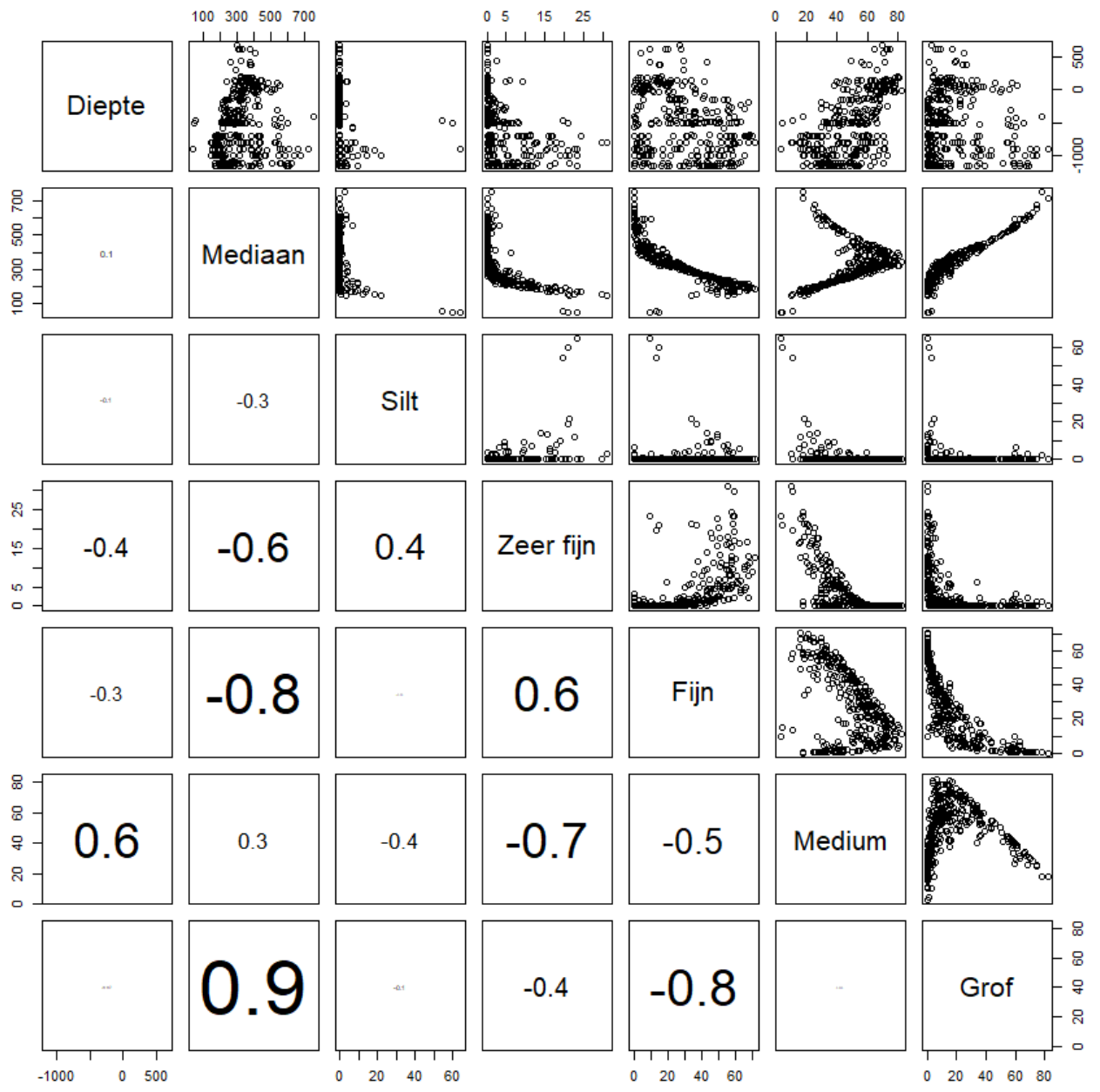

Figuur 10: Correlatiematrix tussen diepte ( $\mathrm{cm}$ t.o.v. NAP), mediane korrelgrootte $(\mu \mathrm{m})$ en percentages silt, zeer fijn zand, fijn zand, medium zand en grof zand in 2019. Onder de diagonaal zijn de correlatiecoëfficiënten gegeven.

De gemiddelde mediane korrelgrootte in 2019 was $329 \mu \mathrm{m}$ (st.dev. $118 \mu \mathrm{m}$ ). De kleinste mediane korrelgrootte $(44 \mu \mathrm{m})$ is gevonden op locatie 2019_007, ten zuiden van de Zandmotor (transect 1 ) op een waterdiepte van ongeveer 9 meter, en de grootste mediane korrelgrootte $(752 \mu \mathrm{m})$ is gevonden op locatie 2017_072, op transect 8 op een waterdiepte van ongeveer 4 meter. 
Diepte is een belangrijke co-variabele voor de mediane korrelgrootte. Een GAM (Generalised Additive Model) is gefit door alle metingen op het strand en de vooroever. Een GAM model bestaat uit verschillende componenten: een link functie van de verklarende variabelen (in dit geval diepte), een systematische component (smoother) en een random component (variatie). De smoother kan variëren van een rechte lijn (aantal vrijheidsgraden $=1$ ) tot een interpolatie van alle datapunten (aantal vrijheidsgraden $=\mathrm{n}-1$ ). In deze studie is de er voor de waarde van de smoother parameter $\mathrm{k}=4$ gekozen. Bij de selectie van het beste model dient aan de ene kant het aantal vrijheidsgraden te worden geminimaliseerd en aan de andere kant dient de fit zo goed mogelijk te zijn. Deze optimalisatie wordt bereikt met behulp van een zogeheten "minimized gereralized cross validation".

Het GAM model van Figuur 11 is significant $(p<0.05)$ en geeft aan dat er een significant effect is van waterdiepte op de mediane korrelgrootte. Op het strand (tot ongeveer 1 meter beneden NAP is de mediane korrelgrootte het grootst. Daarna neemt de mediane korrelgrootte af tot een diepte van ongeveer 7 meter beneden NAP. Op grotere dieptes neemt de mediane korrelgrootte weer iets toe. De zwarte stippen in Figuur 11 zijn de gemiddelde waarde per diepteklasse (iedere meter ten opzichte van NAP).

In het ruimtelijke verspreidingsplaatje (Figuur 12) is wel te zien dat er rond de Zandmotor gebieden zijn met grovere en gebieden met fijnere sedimenten. Zo lijken de sedimenten zeewaarts op de kop van de Zandmotor (transecten 6, 6a, 7 en 7a) grover dan op dezelfde diepte in de gebieden iets ten noorden (transecten 8-a, 9 en 9a) en ten zuiden van de Zandmotor. Ook is er een gebied met relatief grove sedimenten helemaal in het Noorden (transecten 10,10a, 11, 11-a en 12). In de diepere delen van het zuidelijk gebied (transecten $0,0-a, 1$ en $1-a)$ zijn juist fijne sedimenten te vinden.

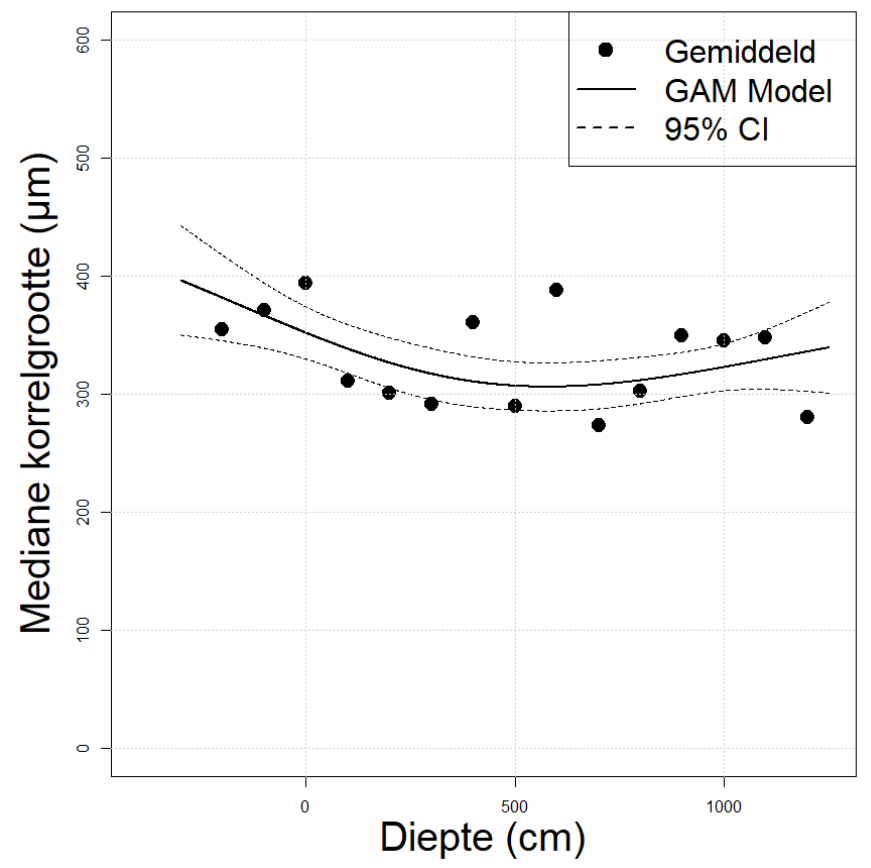

Figuur 11: Mediane korrelgrootte $(\mu \mathrm{m})$ als functie van de waterdiepte ( $\mathrm{cm}$ beneden NAP) voor de monsters die zijn verzameld op het strand en de vooroever. De getrokken lijn is de GAM-regressie en de gestippelde lijnen zijn de $95 \%$ betrouwbaarheidsintervallen. 


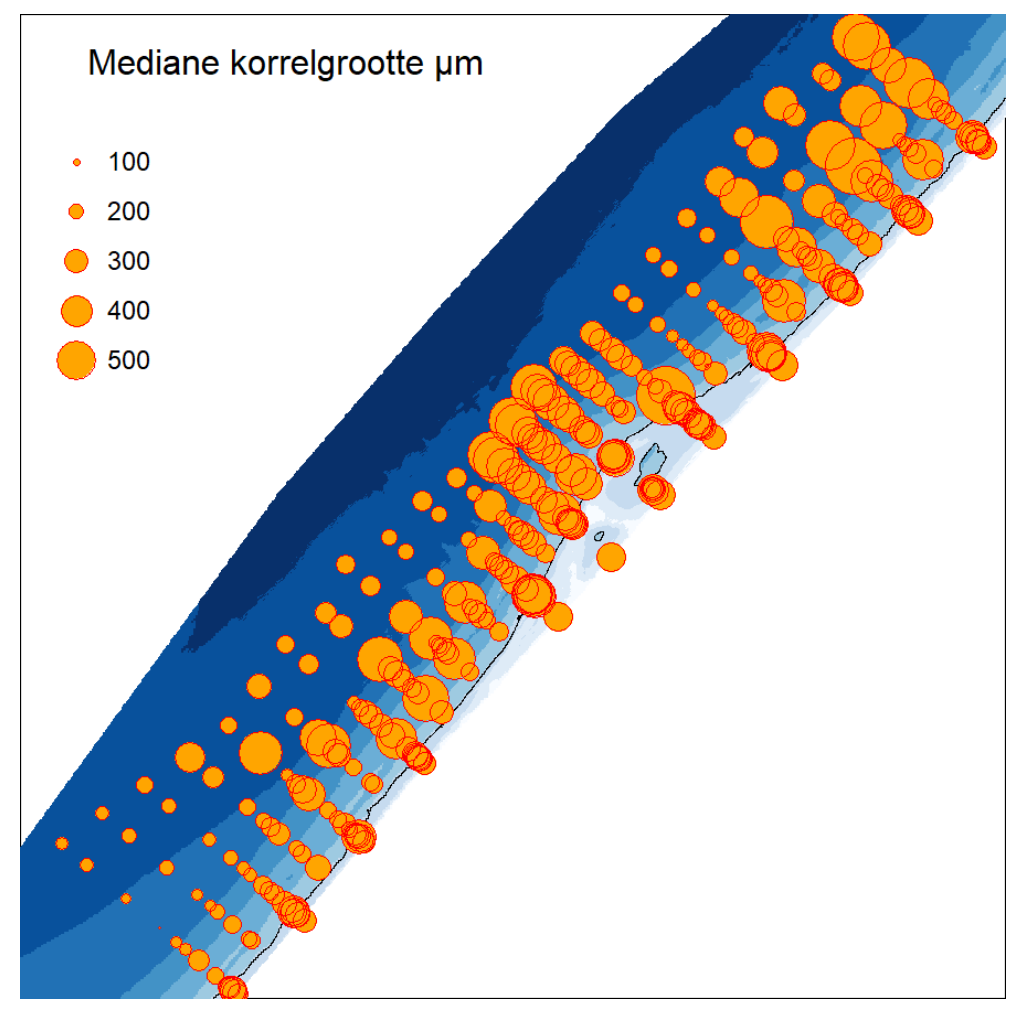

Figuur 12: Ruimtelijke verdeling mediane korrelgrootte $(\mu \mathrm{m})$ in het gebied van de Zandmotor.

In Figuur 13 is voor de verschillende transecten (zie Figuur 1 ) de relatie tussen mediane korrelgrootte en de waterdiepte weergegeven. Transecten 2, 3, 4, 7 en 10 vertonen geen duidelijke relatie met de diepte. Op de transecten 0, 1, 5, 8 en 9 neemt de mediane korrelgrootte af met de diepte. Op het strand is de mediane korrelgrootte vaak groter dan in de ondiepe vooroever. In de diepere delen (dieper dan 7 meter) is er dan een stabilisatie of een lichte stijging in de mediane korrelgrootte. Op transect 6 en 11 neemt de mediane korrelgrootte over het algemeen toe met de diepte. Dit komt deels door de relatief grove sedimenten die zijn gevonden in de diepere delen voor de kop van de Zandmotor (transecten 6 en 6-a) en in het noordelijk deel van het onderzoeksgebied (transecten 11, 11-a en 12). 

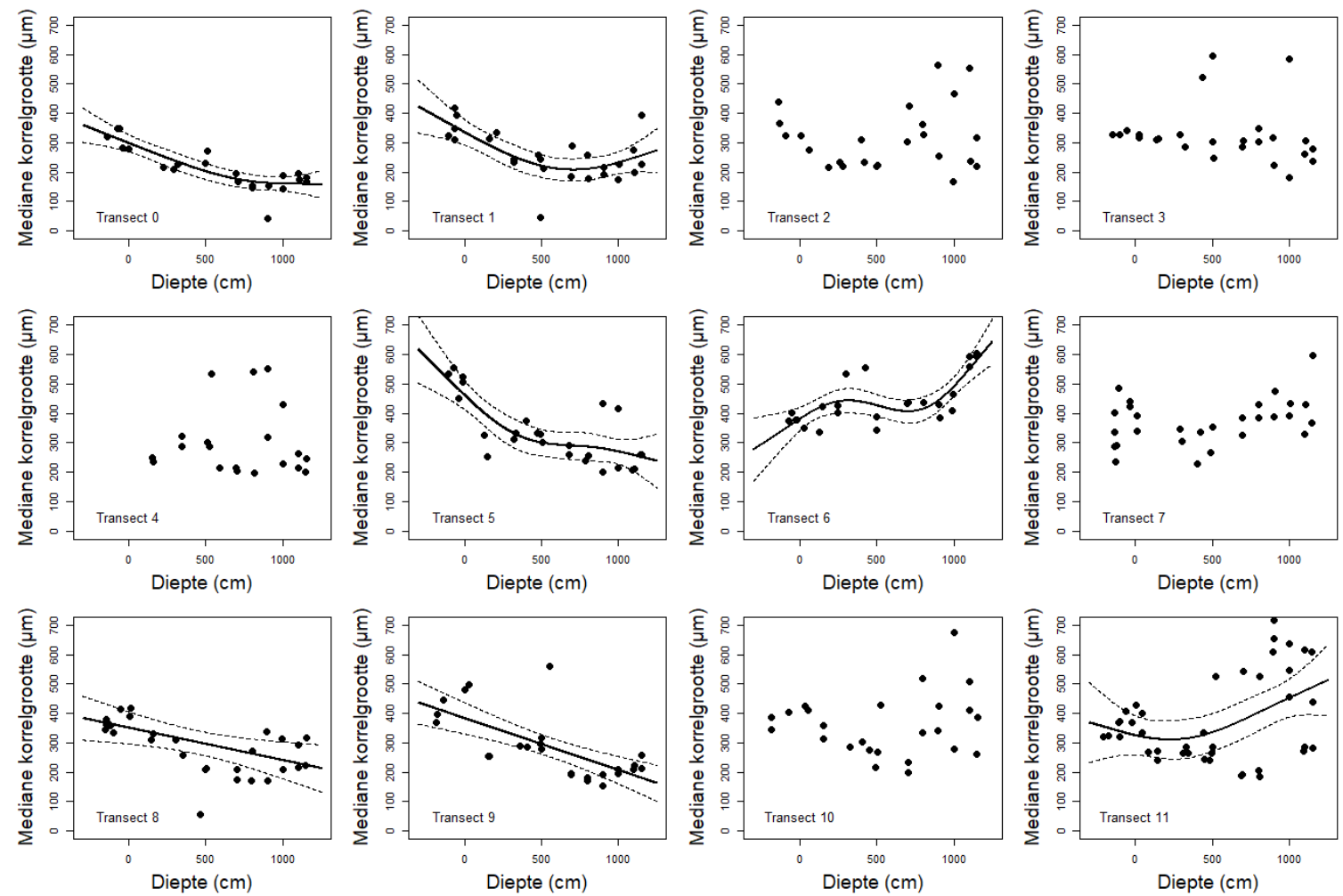

Figuur 13: Resultaat GAM analyses voor de mediane korrelgrootte $(\mu \mathrm{m})$ als functie van de diepteligging t.o.v. NAP voor de verschillende transecten. Iedere figuur bevat de gegevens van twee transecten, het transect zelf $(x)$ en het bijbehorende aanvullende transect voor sediment $(x-a)$, zie (Figuur 1). Alleen de figuur van transect 11 bevat de gegevens van drie transecten (transect 11 , transect $11-a$ en transect 12$)$. Alleen de significante $(p<0.05)$ GAM modellen zijn in de figuren geplot.

\subsubsection{Vergelijk met voorgaande Jaren}

In voorgaande jaren (2010, 2012, 2013, 2015 en 2017) zijn ook de sedimentkarakteristieken bepaald met dezelfde methode. Het aantal sedimentmonsters dat is geanalyseerd, is niet in alle jaren gelijk (Tabel 3). In de vooroever was het om veiligheidsredenen niet altijd mogelijk om de ondiepe stations te bemonsteren. Vanaf 2013 zijn er naast de sedimentmonsters op de reguliere transecten ook nog een aantal (ca 130) monsters genomen op de tussengelegen transecten. Ook zijn er in 2013 en 2015 een aantal (slibrijke) monsters genomen in het sublitoraal deel van de lagune.

Tabel 3: Aantal sedimentmonsters dat is verzameld op en rond de Zandmotor in de verschillende jaren.

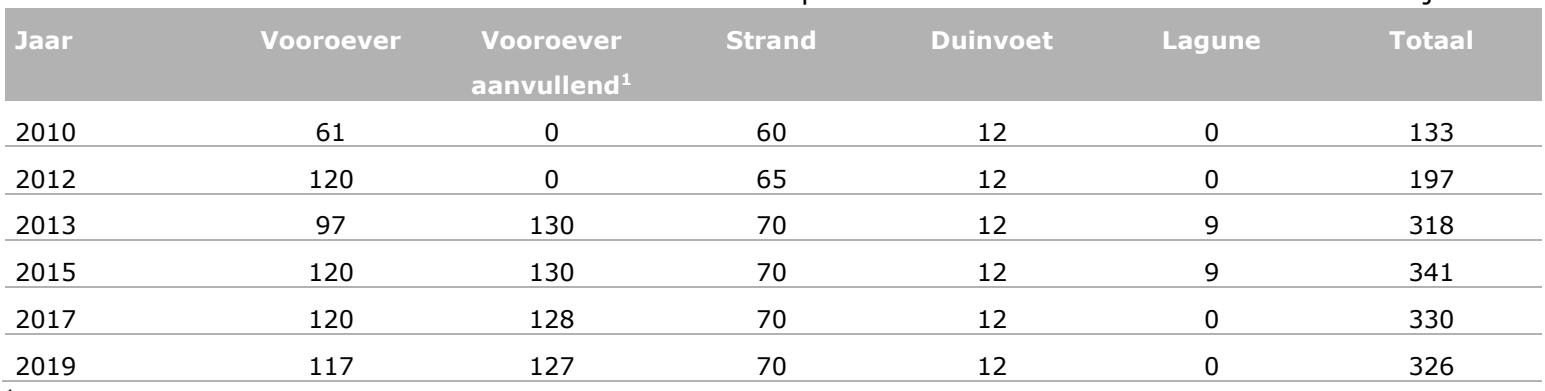

${ }^{1}$ Vanaf 2013 zijn er in de vooroever aanvullende sedimentmonsters genomen op de extra transecten

$\mathrm{Er}$ is geen duidelijke trend in de mediane korrelgrootte over de verschillende jaren (Figuur 14). De slibrijke monsters uit de lagune in de jaren 2013 en 2015 zijn hierbij buiten beschouwing gelaten. De mediane korrelgrootte in 2010 lijkt iets lager dan in de overige jaren, maar dit verschil is niet significant (ANOVA, $p>0.05$ ). 


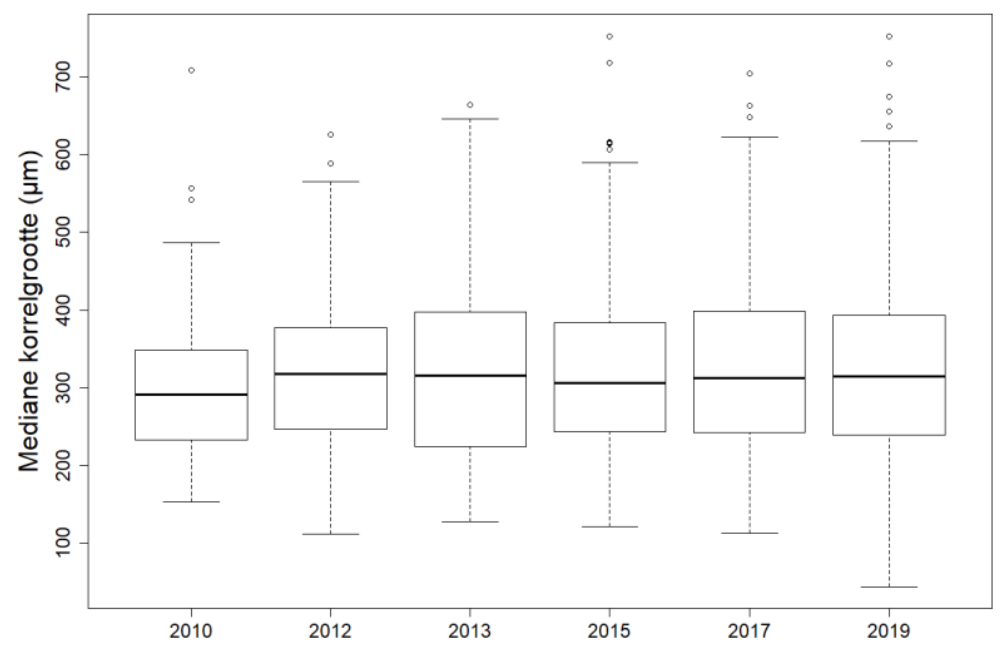

Figuur 14: Boxplots van de mediane korrelgrootte over de verschillende jaren. De slibrijke monsters uit de lagune in de jaren 2013 en 2015 zijn buiten beschouwing gelaten.

In Figuur 15 zijn de resultaten van de GAM regressies over de diepte voor de verschillende jaren weergegeven. Hoewel Figuur 13 liet zien dat er een grote variatie zit over de transecten geven de figuren voor de verschillende jaren het gemiddeld patroon weer. Het patroon van 2019 komt overeen met dat van 2017 en ook wel 2010. In 2013 en 2015, en in mindere mate in 2012 zijn de sedimenten op het strand hoger relatief grof en neemt af naar de ondiepe vooroever (3-5 meter beneden NAP). In 2012 neemt de mediane korrelgrootte weer toe in de diepere delen van de vooroever ( $>8$ meter beneden NAP). In 2019 is dit ook het geval in de transecten 6 en 11 (Figuur 13).
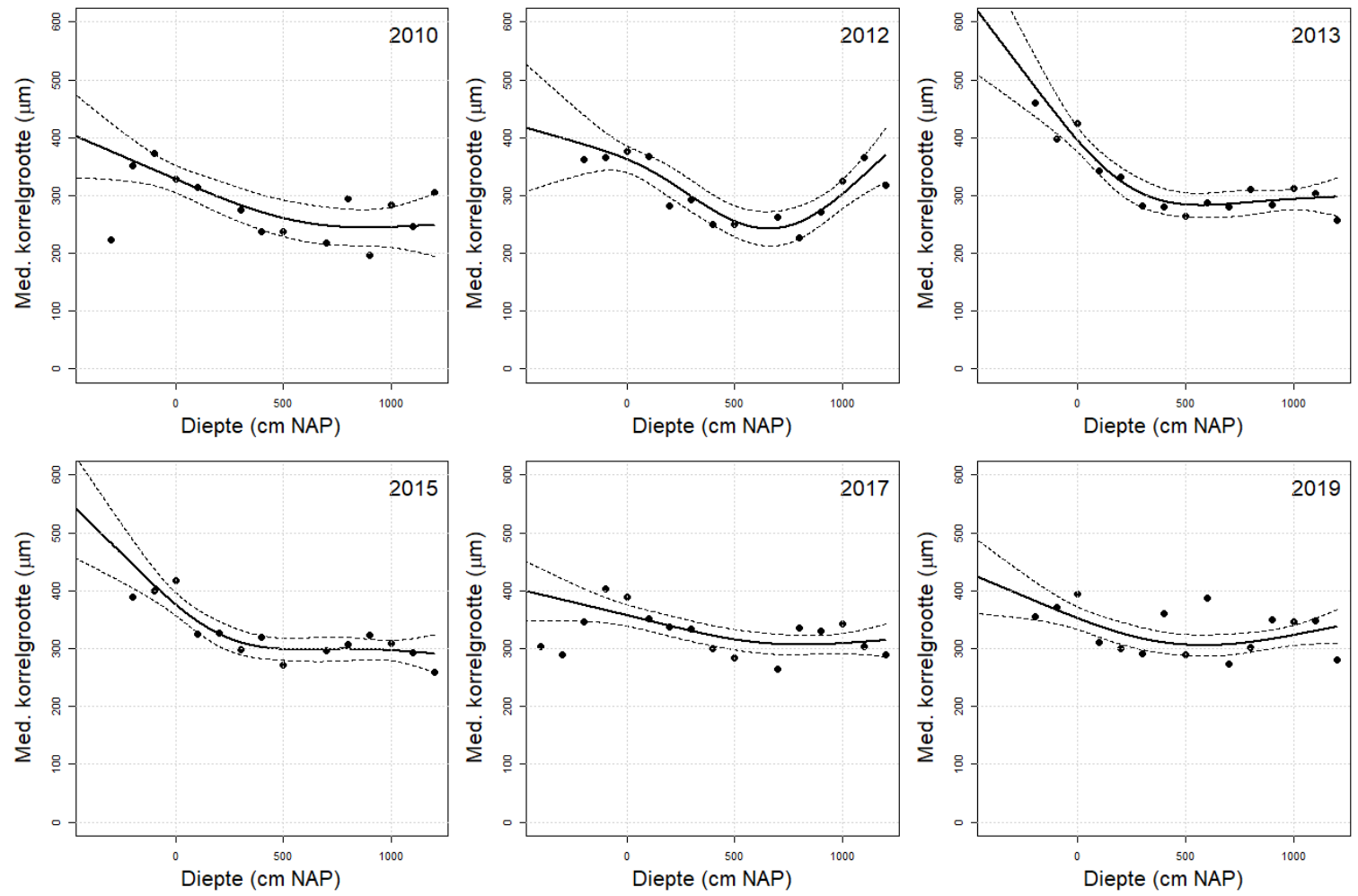

Figuur 15: Mediane korrelgrootte als functie van de diepte ( $\mathrm{cm}$ beneden NAP) voor de verschillende jaren. De getrokken lijnen geven de resultaten van de GAM regressie en de stippellijnen geven de 95\%-betrouwbaarheid intervallen weer. De stippen geven de gemiddelde korrelgrootte per meter-interval. 
In Figuur 16 zijn de ruimtelijke patronen in mediane korrelgrootte gepresenteerd voor de verschillende jaren. Hoewel het beeld vertekend is door het verschil in het aantal bemonsterde stations lijkt er na 2012 een ruimtelijk patroon te zijn ontstaan in de vooroever met relatief grove sedimenten ter hoogte van de Zandmotor (tussen transect 5 en 8), ten zuiden van de Zandmotor (tussen transecten 2 en 4) en in het Noordelijk deel (vanaf transect 10). In de tussenliggende gebieden, aan weerszijden van de Zandmotor, is het sediment juist relatief fijn. Dit ruimtelijk patroon is mogelijk het gevolg van de Zandmotor. De ter hoogte van de Zandmotor is de dynamiek toegenomen waardoor het sediment daar grover is geworden. Juist ten noorden en ten zuiden van de Zandmotor ontstaan wervelingen als gevolg van de kustlangse getijdenbeweging (Huisman et al., 2016). In deze wervelingen kan het fijnere sediment bezinken waardoor de mediane korrelgrootte afneemt.

De relatief grove sedimenten in het noordelijk deel van het onderzoeksgebied (vanaf transect 10) zijn ook al waargenomen in 2010 en hebben waarschijnlijk geen relatie met de aanleg van de Zandmotor. Hetzelfde geldt voor de relatief fijne sedimenten in de diepere delen van de meest zuidelijke transecten. In 2012 echter zijn op transect 1 ook wat grovere sedimenten aangetroffen.

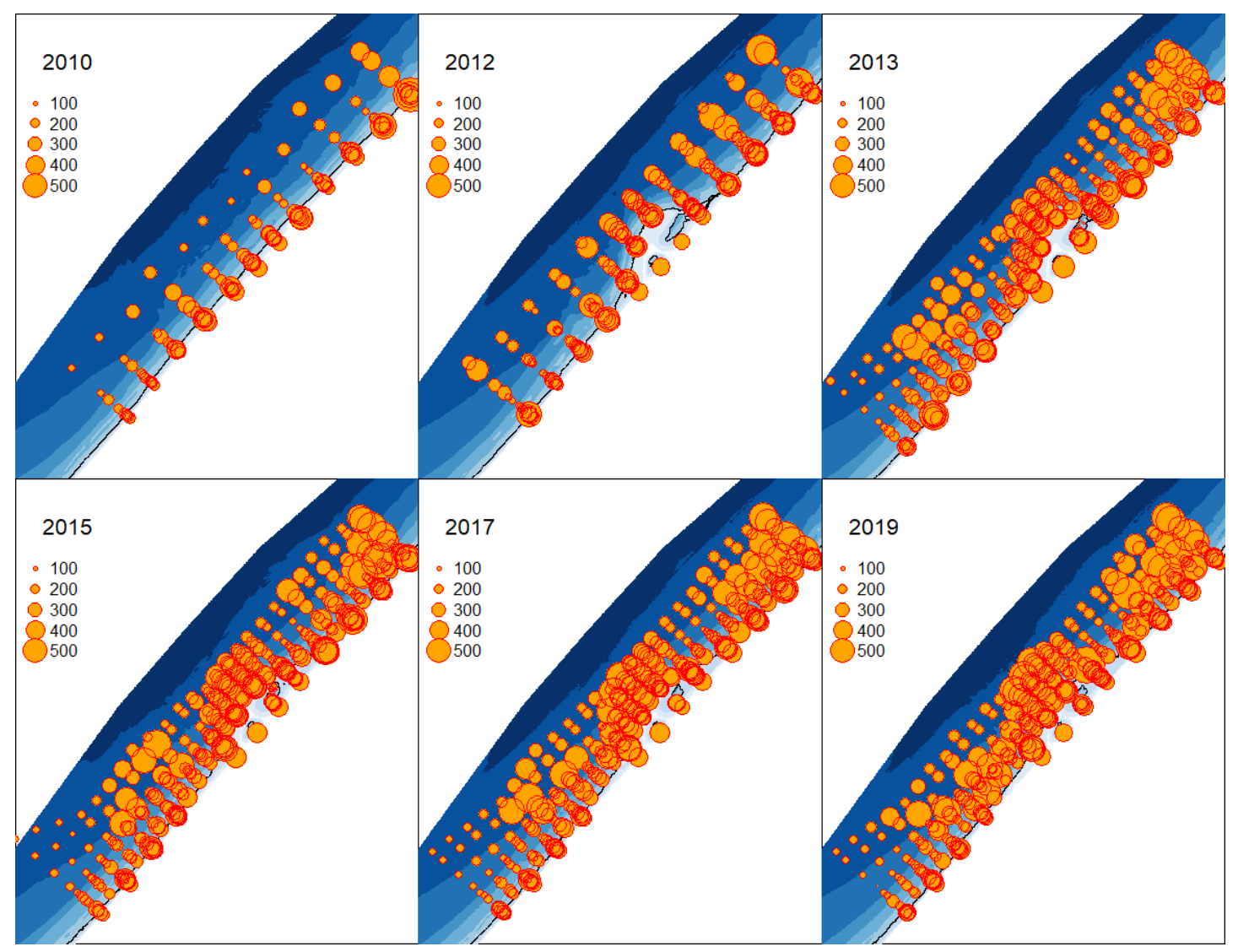

Figuur 16: Ruimtelijke verdeling mediane korrelgrootte $(\mu \mathrm{m})$ in het gebied van de Zandmotor voor de jaren 2010, 2012, 2013, 2015, 2017 en 2019.

\subsubsection{Organisch koolstof en totaal N}

$\mathrm{Er}$ is een duidelijke relatie tussen de mediane korrelgrootte en het organisch koolstofgehalte (Figuur 17). Hoe fijner het sediment, hoe meer organisch stof. De hoogste organisch koolstoffracties worden gemeten in de fijne sedimenten met een mediane korrelgrootte minder dan $200 \mu \mathrm{m}$. Ook zijn er nog een aantal uitbijters die een relatief hoge organisch koolstoffractie hebben in relatie tot de mediane korrelgrootte. Mogelijk heeft er een stukje plantaardig of dierlijk materiaal in deze monsters gezeten. $\mathrm{Er}$ is een exponentiele functie gefit door de data met behulp van de kleinste kwadraten methode $\left(\right.$ OrgC $=433671 \cdot$ MedianeKorrelgrootte $\left.{ }^{-2.897}\right)$. Er is een lineair verband tussen de log-getransformeerde waarden van het organisch koolstof en de log-getransformeerde waarden van totaal $\mathrm{N}$ ( $\ln$ (TotalN = $-2.535+0.785 \cdot \ln (\operatorname{OrgC})$, Figuur 17). Van belang in deze figuren is dat de meeste metingen beneden de detectielimiet liggen voor het organisch koolstof (0.04\%). Beneden deze waarde neemt de betrouwbaarheid van de analyse af. 

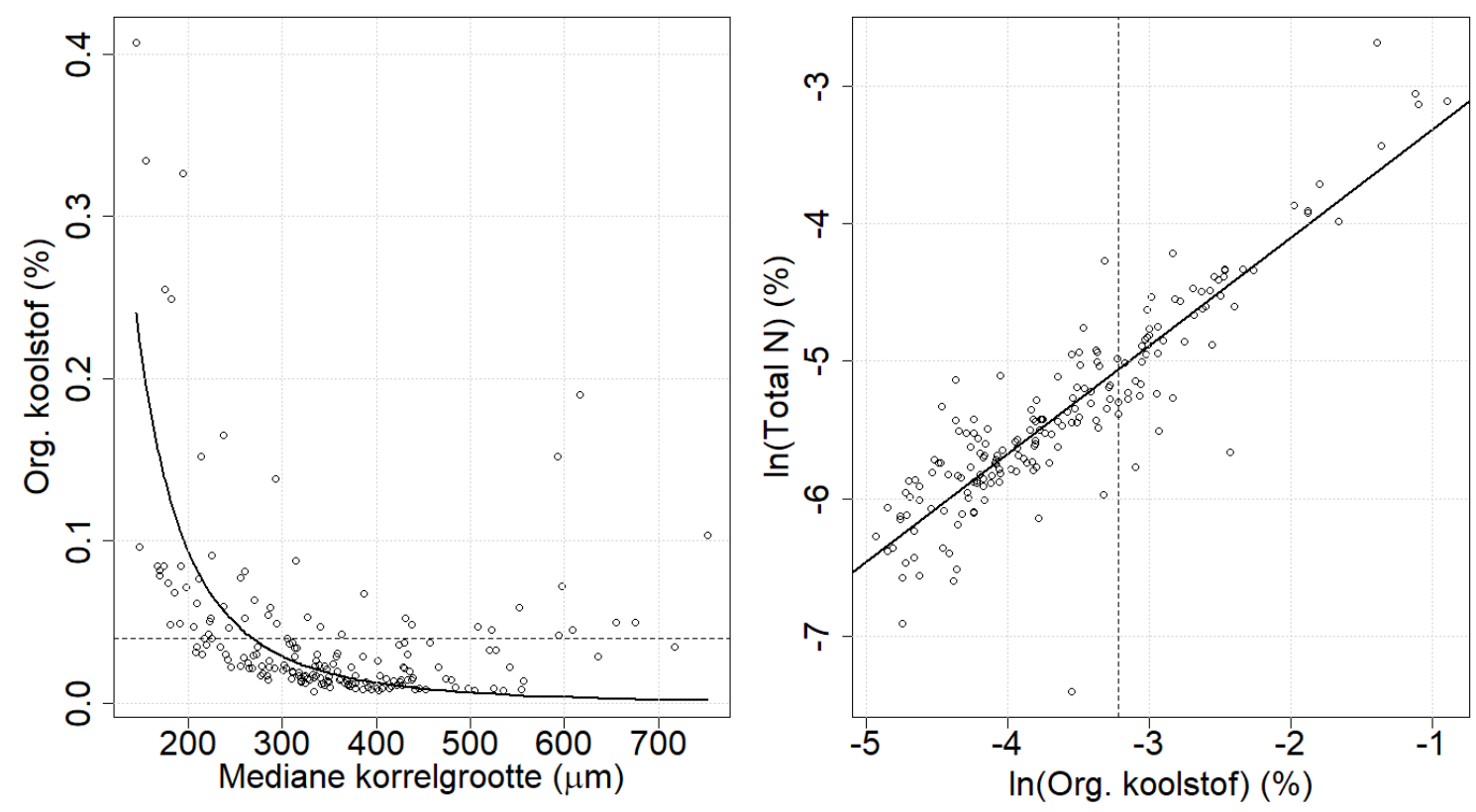

Figuur 17: Relatie tussen het organisch koolstofgehalte en de mediane korrelgrootte (links) en totaal stikstof en organisch koolstof (rechts) voor de sedimentgegevens uit 2019. De getrokken lijnen geven de resultaten van de regressies (zie tekst). De stippellijnen geven de detectielimiet voor het organisch koolstofgehalte $(0.04 \%)$.

In Figuur 18, linker figuur is te zien dat er een ruimtelijk patroon is in het organisch koolstof gehalte van de toplaag van het sediment op en rond de Zandmotor. De hoogste gehalten worden aangetroffen in de ondiepe vooroever, ten noorden en ten zuiden van de Zandmotor bij een waterdiepte van ca 5 meter maar ook in de ondiepe vooroever van Transecten 0, 1 en 2. Ook zijn er relatief hoge gehalten aan organisch koolstof aangetroffen op de stations aan het strand langs de zuidoever van de lagune. De overige stations op het strand en ook in de ondiepe brandingszone zijn relatief arm aan organisch koolstof. In het rechter deel van Figuur 18 is het absolute verschil in het percentage organisch koolstof tussen het model (getrokken lijn in Figuur 17, linker figuur) en de observaties. De locaties met de zalmkleurige stippen zijn de positieve residuelen. Op die locaties is dus een hoger gehalte aan organisch koolstof gemeten dan voorspeld met het model. De groene stippen zijn de negatieve residuelen en op die locaties is dus een lager gehalte aan organisch koolstof aangetroffen dan voorspeld met model. De positieve residuelen liggen voornamelijk in de ondiepe vooroever bij een diepte van 5 tot 10 meter en op het strand langs de zuidrand van de lagune. Opvallend is dat de ondiepe delen van de meest zuidelijke transecten $(0,1$ en 2$)$ relatief arm zijn aan organisch materiaal, terwijl de diepere delen van de noordelijkste transecten relatief rijk zijn aan organisch materiaal rekening houdend met de mediane korrelgrootte (Figuur 18). 


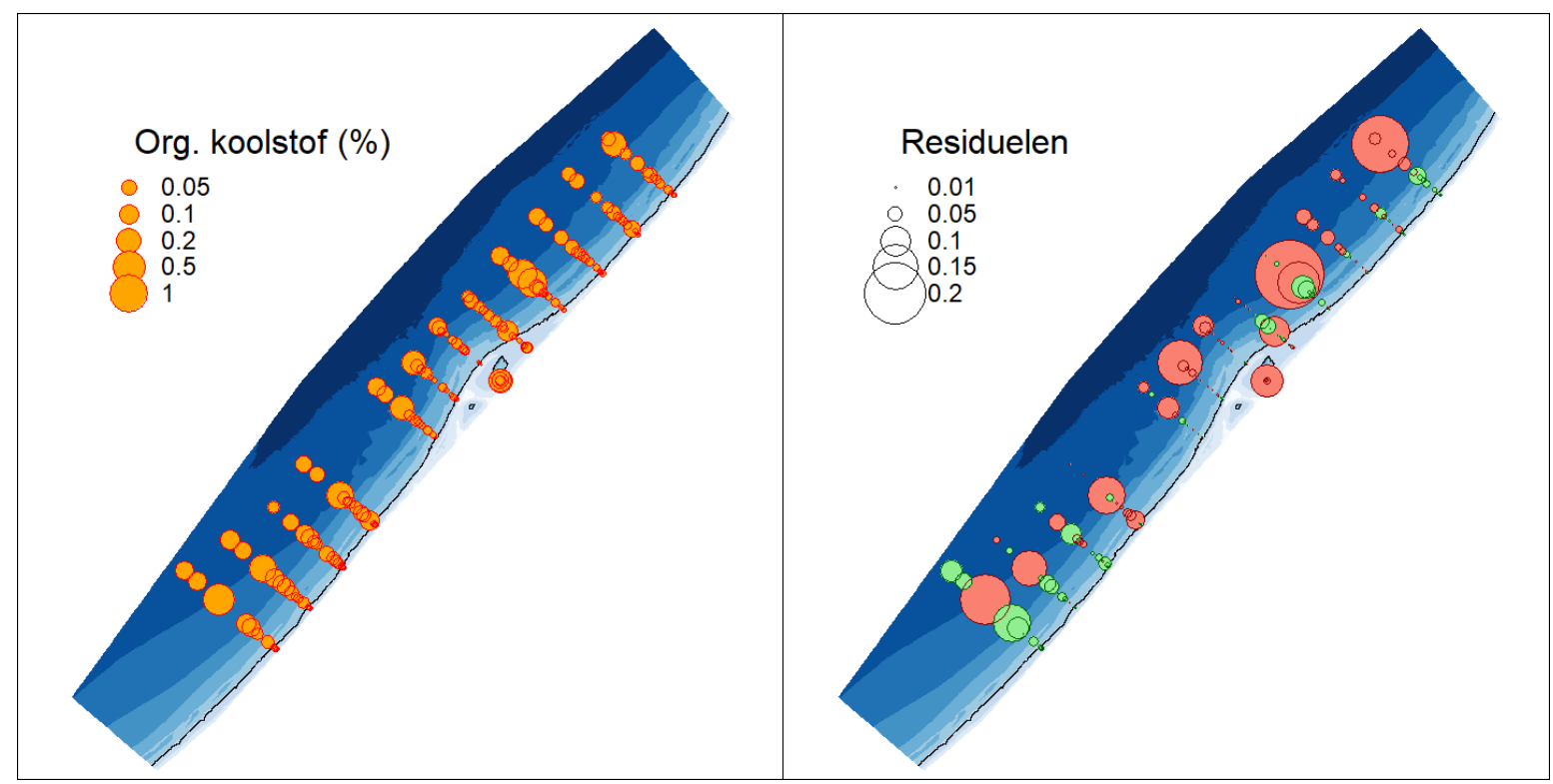

Figuur 18: Ruimtelijke verspreiding van het gehalte organisch koolstof (\%) (links). In de rechter figuur zijn de residuelen uitgezet tussen het model (getrokken lijn in Figuur 17, linker panel) en de observaties. De locaties met de zalmkleurige stippen zijn positieve residuelen en hebben een hoger gehalte aan organisch koolstof dan voorspelt met het model. De groene stippen zijn negatieve residuelen en hebben lager gehalte aan organisch koolstof dan voorspelt met model.

\subsection{Bodemschaaf}

\subsubsection{Overzicht}

In totaal zijn er in 2019113 locaties in de vooroever bemonsterd met de bodemschaaf. De minimale treklengte was 72 meter en de maximale treklengte was 150 meter (gemiddeld 114 meter, standaard deviatie 12 meter). Op locatie 2019_032 zijn geen levende bodemdieren aangetroffen. De gemiddelde dichtheid aan bodemdieren in 2019 is 190 individuen $\mathrm{m}^{-2}$ (st. dev. 1074 individuen $\mathrm{m}^{-2}$ ). Dit is hoger dan in voorgaande jaren. In 2012, 2013 en 2017 was de gemiddelde dichtheid respectievelijk 136, 100 en 121 individuen $\mathrm{m}^{-2}$. In 2010 en 2015 was de gemiddelde dichtheid het laagst (respectievelijk 18 en 23 individuen per $\mathrm{m}^{-2}$. De hoogste dichtheid (11000 individuen $\mathrm{m}^{-2}$ ) is in 2019 aangetroffen op station 2019_087. 

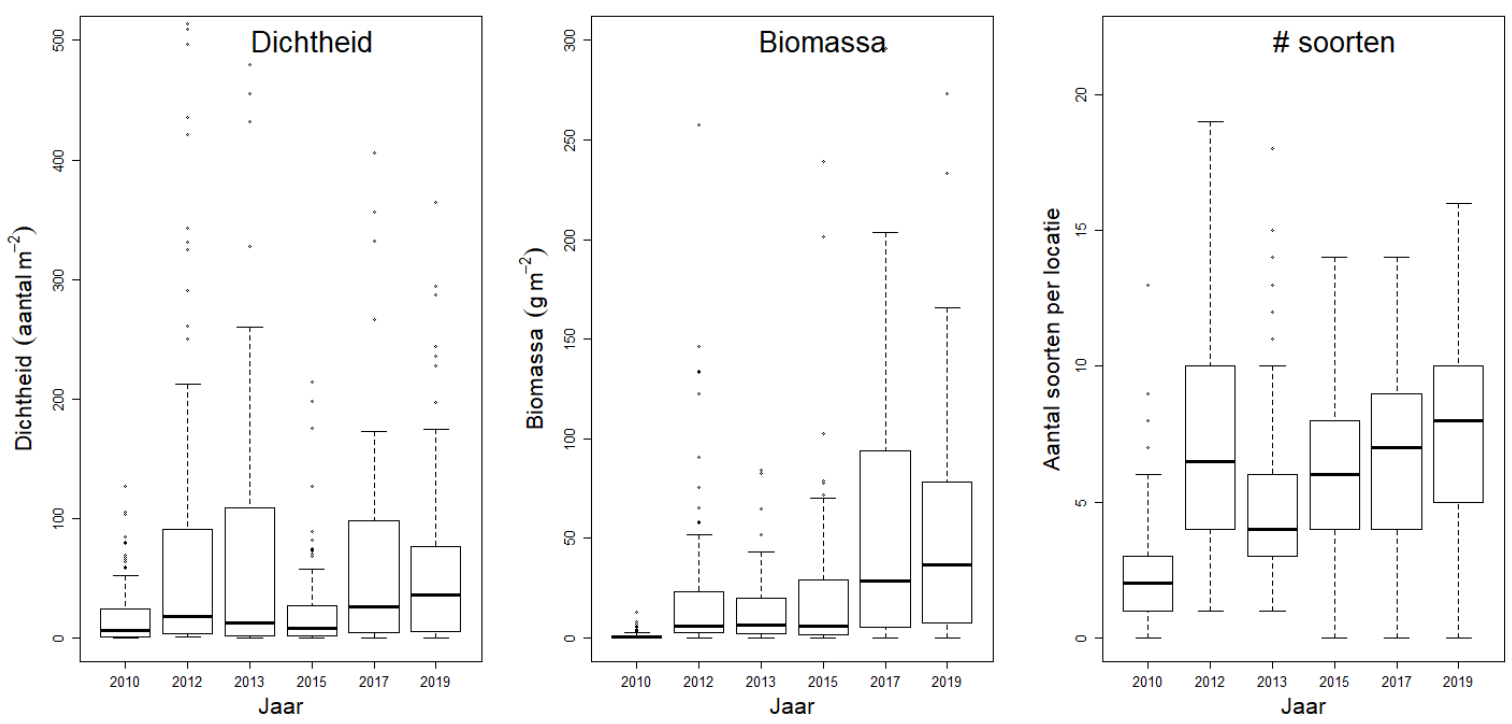

Figuur 19: Boxplots van de dichtheid (aantal $\mathrm{m}^{-2}$ ), biomassa ( $\mathrm{g}$ versgewicht $\mathrm{m}-2$ ) en het aantal soorten per locatie over de jaren 2010 tot en met 2019. Bij de biomassa is Ensis spp. niet meegenomen. De $\mathrm{y}$-assen van de dichtheid en biomassa zijn afgekapt bij respectievelijk 500 individuen $\mathrm{m}^{-2}$ en 300

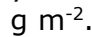

De gemiddelde biomassa (zonder Ensis spp., strandgapers, otterschelpen en heremietkreeften) was $75 \mathrm{~g} \mathrm{~m}^{-2}$. Dit is iets minder dan in 2017 (84.5 $\mathrm{g} \mathrm{m}^{-2}$ ) maar aanzienlijk meer dan in de jaren ervoor (Figuur 19). De gemiddelde dichtheid in de jaren 2010, 2012, 2013 en 2015 was respectievelijk 1, 23, 14 en $24 \mathrm{~g} \mathrm{~m}^{-2}$. De hoogste biomassa in 2019 is gemeten op station 2019 _087 $\left(1418 \mathrm{~g} \mathrm{~m}^{-2}\right)$, voornamelijk bestaande uit Abra alba en Spisula subtruncata. Het gemiddelde aantal soorten per locatie in 2019 was 7.8. Dit is hoger dan in voorgaande jaren. Het maximum aantal soorten per locatie was 16. In 2012 en 2013 was het maximum aantal soorten respectievelijk 19 en 18.

In totaal zijn er in 201932 taxa aangetroffen in de monsters (Tabel 4). De meest verspreide taxa zijn het zaagje (Donax vittatus), het nonnetje (Limecola balthica), de halfgeknotte strandschelp (Spisula subtruncata), de kleine heremietkreeft (Diogenes pugilator), de gewone zwemkrab (Liocarcinus holsatus), zwaardscheden (Ensis spp.), de breedpootkrab (Portumnus latipes), de rechtsgestreepte platschelp (Fabulina fabula) en de gewone slangster (Ophiura ophiura). Opvallende nieuwkomer in de observaties van 2019 is de Amerikaanse strandschelp (Mulinia lateralis). Deze exoot is in 2017 voor het eerst aangetroffen in de Voordelta (Craeymeersch et al., 2019), en blijkt nu ook de Zandmotor te hebben bereikt. De soort is in 2019 al op ruim 20\% van de bemonsterde locaties aangetroffen. 
Tabel 4: Aantal stations dat taxon is aangetroffen in een monster met de bodemschaaf. In 2010, 2012, 2013, 2015, 2017 en 2019 zijn er respectievelijk 114, 120, 113, 109, 107 en 113 locaties bemonsterd.

\begin{tabular}{|c|c|c|c|c|c|c|c|}
\hline Taxon & 2010 & 2012 & 2013 & 2015 & 2017 & 2019 & Totaal \\
\hline Ensis spp. & 91 & 106 & 86 & 82 & 70 & 70 & 505 \\
\hline Diogenes pugilator & 50 & 114 & 57 & 86 & 80 & 85 & 472 \\
\hline Liocarcinus holsatus & 5 & 104 & 82 & 72 & 55 & 73 & 391 \\
\hline Spisula subtruncata & 18 & 68 & 41 & 65 & 69 & 90 & 351 \\
\hline Portumnus latipes & 39 & 69 & 41 & 44 & 43 & 58 & 294 \\
\hline Donax vittatus & 6 & 9 & 19 & 54 & 92 & 97 & 277 \\
\hline Limecola balthica & 0 & 25 & 20 & 41 & 63 & 91 & 240 \\
\hline Pagurus bernhardus & 6 & 59 & 28 & 69 & 24 & 30 & 216 \\
\hline Abra alba & 15 & 50 & 22 & 20 & 40 & 30 & 177 \\
\hline Spisula solida & 5 & 43 & 18 & 29 & 28 & 30 & 153 \\
\hline Fabulina fabula & 1 & 30 & 19 & 12 & 36 & 49 & 147 \\
\hline Ophiura ophiura & 9 & 33 & 15 & 17 & 32 & 40 & 146 \\
\hline Lutraria lutraria & 6 & 4 & 6 & 25 & 23 & 17 & 81 \\
\hline Euspira nitida & 12 & 27 & 14 & 15 & 4 & 3 & 75 \\
\hline Actiniaria & 21 & 21 & 7 & 16 & 9 & 0 & 74 \\
\hline Chamelea striatula & 1 & 2 & 8 & 18 & 17 & 28 & 74 \\
\hline Nassarius nitidus & 7 & 33 & 8 & 0 & 15 & 10 & 73 \\
\hline Tritia reticulata & 0 & 8 & 25 & 2 & 0 & 2 & 37 \\
\hline Carcinus maenas & 8 & 9 & 3 & 4 & 4 & 5 & 33 \\
\hline Spisula elliptica & 0 & 10 & 11 & 5 & 0 & 0 & 26 \\
\hline Macomangulus tenuis & 0 & 2 & 8 & 1 & 6 & 8 & 25 \\
\hline Mytilus edulis & 1 & 7 & 3 & 0 & 6 & 8 & 25 \\
\hline Mulinia lateralis & 0 & 0 & 0 & 0 & 0 & 24 & 24 \\
\hline Asterias rubens & 0 & 2 & 7 & 3 & 0 & 6 & 18 \\
\hline Ophiura albida & 1 & 8 & 2 & 0 & 2 & 1 & 14 \\
\hline Liocarcinus navigator & 2 & 1 & 0 & 1 & 0 & 9 & 13 \\
\hline Corystes cassivelaunus & 3 & 1 & 1 & 1 & 1 & 1 & 8 \\
\hline Echinocardium cordatum & 0 & 0 & 6 & 0 & 2 & 0 & 8 \\
\hline Crepidula fornicata & 0 & 0 & 2 & 0 & 2 & 2 & 6 \\
\hline Euspira catena & 0 & 0 & 0 & 0 & 1 & 4 & 5 \\
\hline Liocarcinus marmoreus & 0 & 0 & 0 & 0 & 0 & 5 & 5 \\
\hline Sagartia troglodytes & 0 & 0 & 4 & 0 & 0 & 0 & 4 \\
\hline Ruditapes philippinarum & 0 & 0 & 0 & 0 & 0 & 3 & 3 \\
\hline Thia scutellata & 1 & 1 & 0 & 0 & 0 & 1 & 3 \\
\hline Pinnotheres pisum & 0 & 0 & 0 & 0 & 0 & 2 & 2 \\
\hline Venerupis corrugata & 0 & 1 & 0 & 0 & 1 & 0 & 2 \\
\hline Abra prismatica & 0 & 0 & 0 & 0 & 0 & 1 & 1 \\
\hline Acanthocardia echinata & 0 & 0 & 0 & 1 & 0 & 0 & 1 \\
\hline Liocarcinus depurator & 0 & 0 & 0 & 1 & 0 & 0 & 1 \\
\hline Macropodia & 0 & 0 & 0 & 0 & 1 & 0 & 1 \\
\hline Mya arenaria & 0 & 0 & 1 & 0 & 0 & 0 & 1 \\
\hline Petricolaria pholadiformis & 0 & 0 & 0 & 1 & 0 & 0 & 1 \\
\hline
\end{tabular}

In 2019 zijn er meer soorten aangetroffen in de monsters dan in de voorgaande Jaren (Figuur 20). Het geschatte totaal aantal soorten in 2019 was 36 (eerste orde Jackknife). De minste soorten zijn geschat voor 2010 (27 soorten). In 2012, 2013, 2015 en 2017 was het geschatte aantal soorten respectievelijk 32, 31, 32 en 31 soorten. 


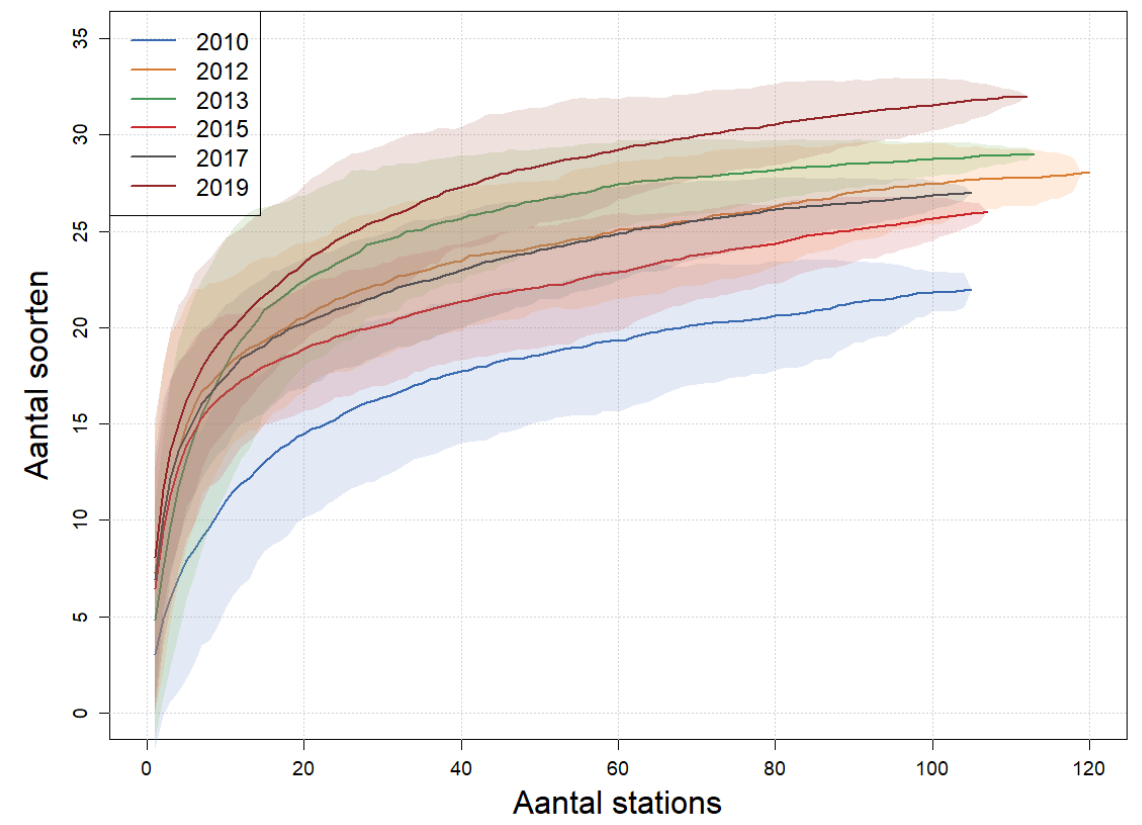

Figuur 20: Cumulatief aantal soorten als functie van het aantal bemonsterde stations voor de verschillende jaren. De getrokken lijnen geven het gemiddelde aantal soorten en de vlakken geven de standaarddeviatie.

De halfgeknote strandschelp (Spisula subtruncata) en witte dunschaal (Abra alba), nonnetje (Limecola balthica) en zaagje (Donax vittatus) waren de meest dominante soorten met gemiddelde dichtheden van respectievelijk 93, 52, 13 en 13 individuen $\mathrm{m}^{-2}$ (Figuur 21). De gemiddelde dichtheid van de Amerikaanse strandschelp (Mulinia lateralis) was 9 individuen $\mathrm{m}^{-2}$. Ook in termen van biomassa was de halfgeknotte strandschelp de meest dominante soort met een gemiddelde biomassa van $35 \mathrm{~g} \mathrm{~m}^{-2}$, gevolgd door het zaagje (Donax vitatus $16 \mathrm{~g} \mathrm{~m}^{-2}$ ), nonnetje (Limecola balthica, $8 \mathrm{~g} \mathrm{~m}^{-2}$ ) en (Abra alba, $\left.6 \mathrm{~g} \mathrm{~m}^{-2}\right)$. 


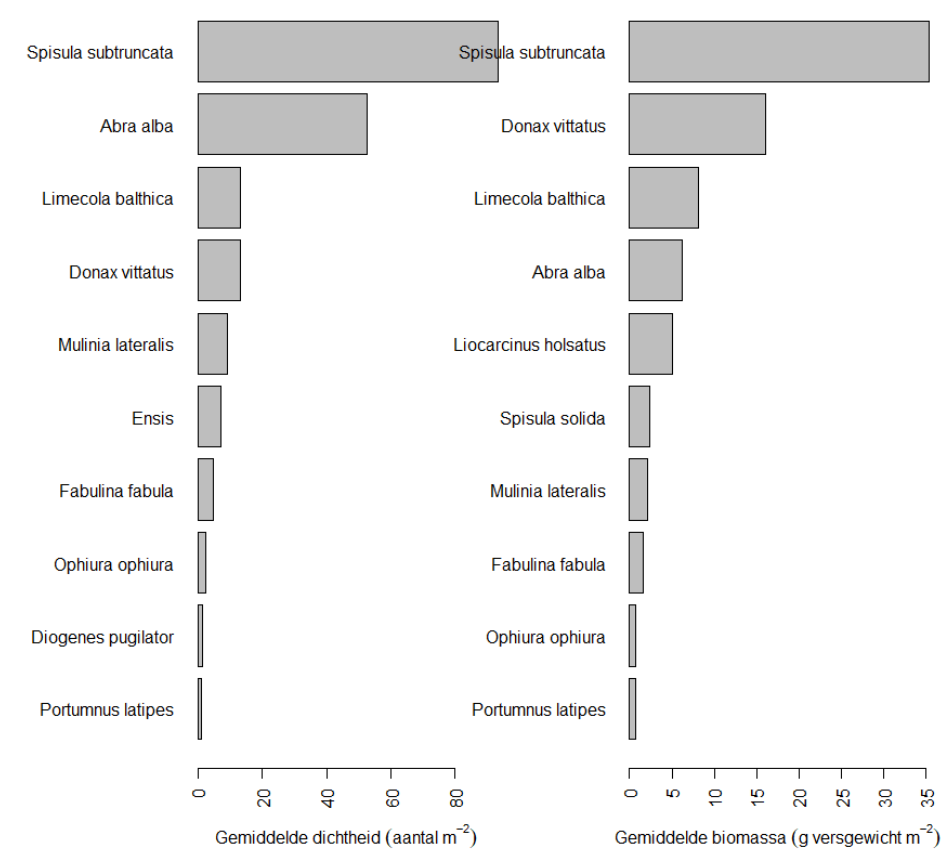

Figuur 21: Gemiddelde dichtheden en biomassa's van de 10 meest dominante soorten bij de bemonstering met de bodemschaaf in 2019. De soorten Ensis spp. Diogenes pugilator, Pagurus bernardus, Mya arenaria en Lutraria lutraria zijn niet meegenomen in de biomassabepaling.

In figuur Figuur 22 is te zien dat in de jaren 2010 en 2013 en in mindere mate in 2012, slechts 1 soort (Ensis spp.) verantwoordelijk is voor meer dan $70 \%$ van de totale dichtheid aan bodemdieren in de bodemschaaf. De tweede belangrijke soort in 2012 is de witte dunschaal ( $A b r a$ alba). In 2019 is de halfgeknotte strandschelp (Spisula subtruncata) de belangrijkste soort in dichtheid, gevolgd door de witte dunschaal (Abra alba). Enis spp. komt pas op de $6^{\mathrm{e}}$ plaats. In 2019 waren respectievelijk het zaagje (Donax vitatus) en de halfgeknotte strandschelp (Spisula subtruncata) de belangrijkste soorten. De cumulatieve plots voor de biomassa laten een meer eenduidig beeld zien omdat Ensis spp. hier niet is meegenomen.
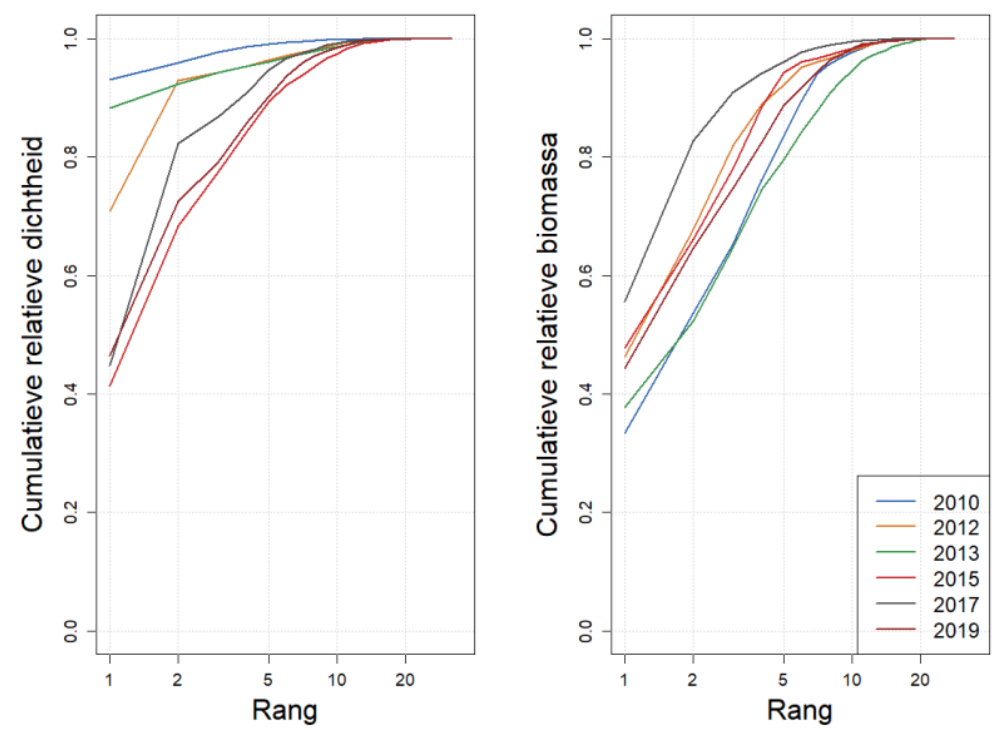

Figuur 22: Cumulatieve relatieve dichtheid (links) en de cumulatieve relatieve biomassa (rechts) als functie van de rangorde voor de jaren 2010 tot en met 2019. De soorten Ensis spp. Diogenes pugilator, Pagurus bernardus, Mya arenaria en Lutraria lutraria zijn niet meegenomen in de biomassa (rechter figuur). 
Opvallend in de bemonstering van 2019 is het relatieve grote aandeel van de soorten Amerikaanse strandschelp (Mulinia lateralis), venusschelp (Chamelea striatula), rechtsgestreepte strandschelp (Fabulina fabula) en halfgeknotte strandschelp (Spisula subtruncata) zijn de biomassa's in 2019 aanzienlijk groter dan gemiddeld over de voorgaande jaren (Figuur 23). De biomassa's van soorten als de ovale strandschelp (Spisula elliptica), anemonen (Actinaria), de gevlochten fuikhoren (Tritia reticulata), gewone zeester (Asterias rubens)en de glanzende tepelhoren (Euspira nitida) was in 2019 aanzienlijk lager dan gemiddeld in 2010 tot en met 2017. Vergleken met 2017 is de gemiddelde biomassa van de soorten Amerikaanse strandschelp (Mulinia lateralis), rechtsgestreepte strandschelp (Fabulina fabula), venusschelp (Chamelea striatula), gewone slangster (Ophiura ophiura) en witte dunschaal (Abra alba) toegenomen en het zaagje (Donax vittatus) en anemonen (Actinaria) zijn in 2019 juist afgenomen ten opzichte van 2017.

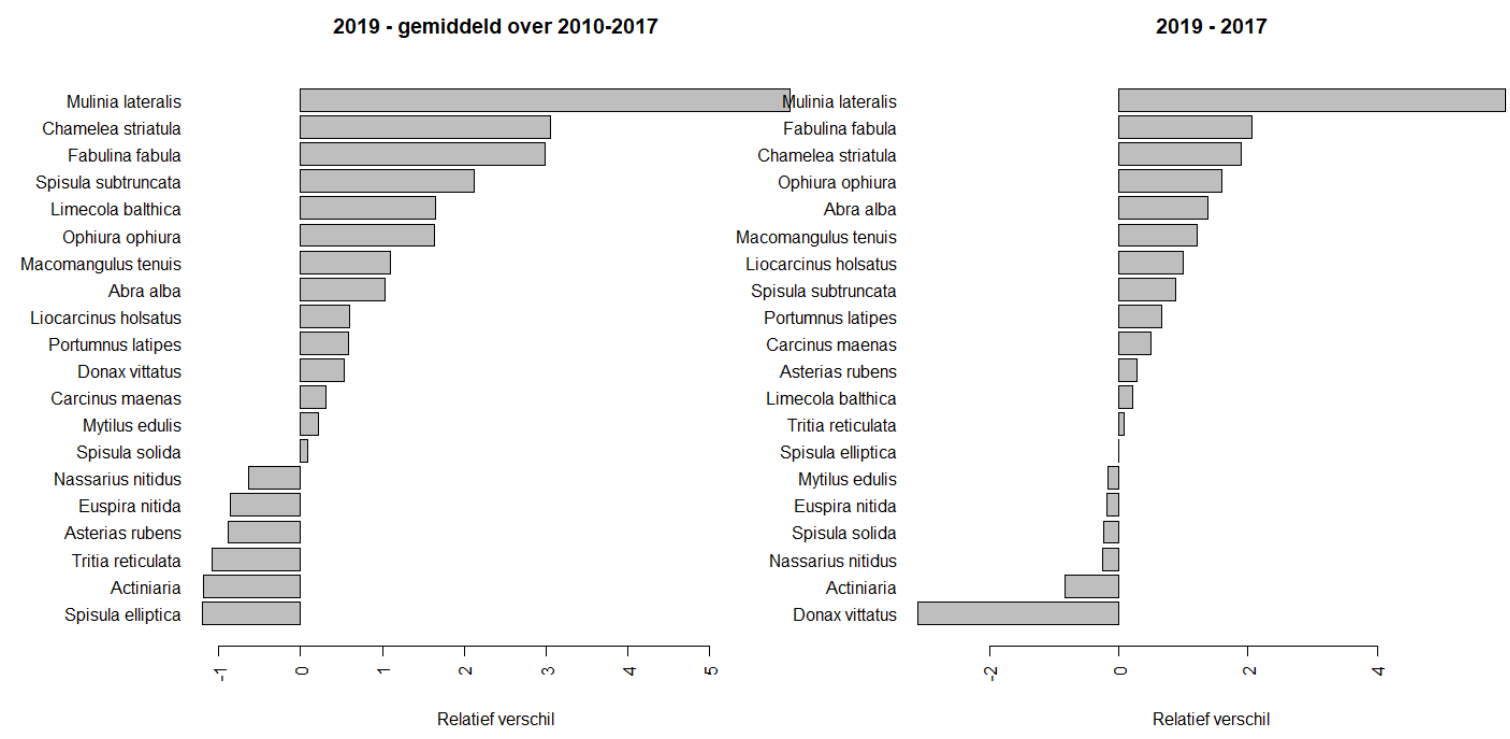

Figuur 23: Relatieve veranderingen in de gemiddelde biomassa van de 20 meest dominante soorten qua biomassa (Ensis spp. niet meegenomen). In de linker figuur is het verschil in de gemiddelde biomassa in 2019 en de gemiddelde biomassa in de periode 2010 tot en met 2017 gedeeld door de gemiddelde biomassa over alle jaren. In de rechter figuur is het verschil tussen de gemiddelde biomassa in 2019 en 2017 gedeeld door de gemiddelde biomassa over alle jaren.

\subsubsection{Relatie met waterdiepte}

$\mathrm{Er}$ is een duidelijke relatie tussen de hoeveelheid bodemdieren (dichtheid, biomassa en aantal soorten) en de waterdiepte (Figuur 24). In het ondiepe, dynamische deel van de vooroever ( $<6$ meter onder NAP) is de dichtheid en biomassa van de bodemdieren zeer laag. Vanaf een diepte van 5 á 6 meter nemen zowel de gemiddelde biomassa als de dichtheid toe. Ook het aantal soorten per monster neemt toe met de waterdiepte, van gemiddeld minder dan 5 soorten bij een diepte van minder dan 5 meter onder NAP tot gemiddeld ongeveer 10 soorten per monster vanaf een diepte van 10 meter onder NAP. 

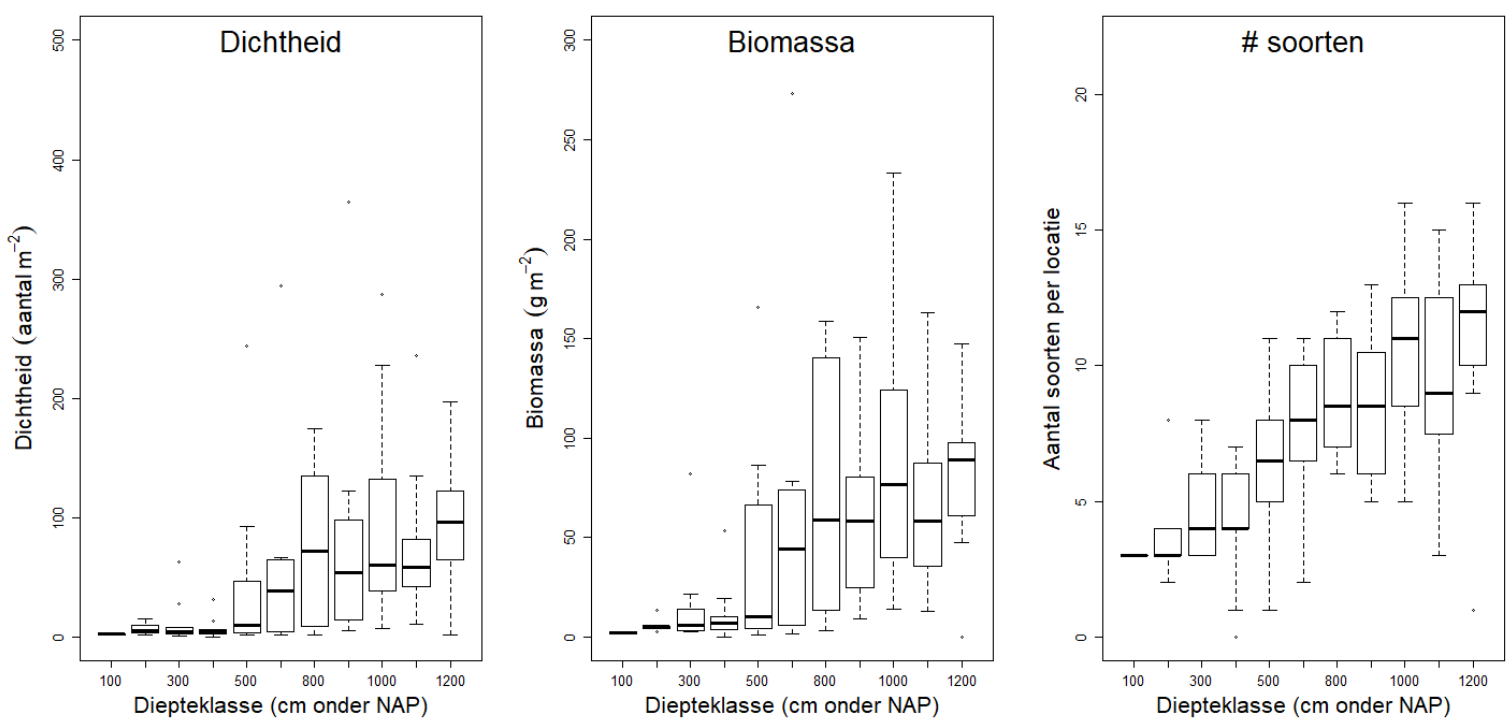

Figuur 24: Boxplots van de dichtheid (aantal $\mathrm{m}^{-2}$ ), biomassa ( $\mathrm{g}$ versgewicht $\mathrm{m}^{-2}$ ) en het aantal soorten per locatie in 2019 als functie van over de diepteklasse. Bij de biomassa is Ensis spp. niet meegenomen.

Hetzelfde beeld is te zien in de resultaten van de GAM analyse voor de dichtheid en de biomassa (zonder Ensis spp., strandgapers, otterschelpen en heremietkreeften) (Figuur 25). De GAM modellen is gebaseerd op de vierdemachtswortel-getransformeerde dichtheid en biomassa data. De modellen zijn significant $(p<0.05)$ en geeft aan dat er een (niet-lineair) effect is van de waterdiepte op zowel de dichtheid als de biomassa. De punten in de figuren geven respectievelijk de gemiddelde dichtheid en biomassa aan bodemdieren per diepteklasse weer (afgerond op hele meters). In de figuur is ook duidelijk te zien dat zowel de dichtheid als de biomassa snel toeneemt van een diepte van ca 5 á 6 meter beneden NAP.
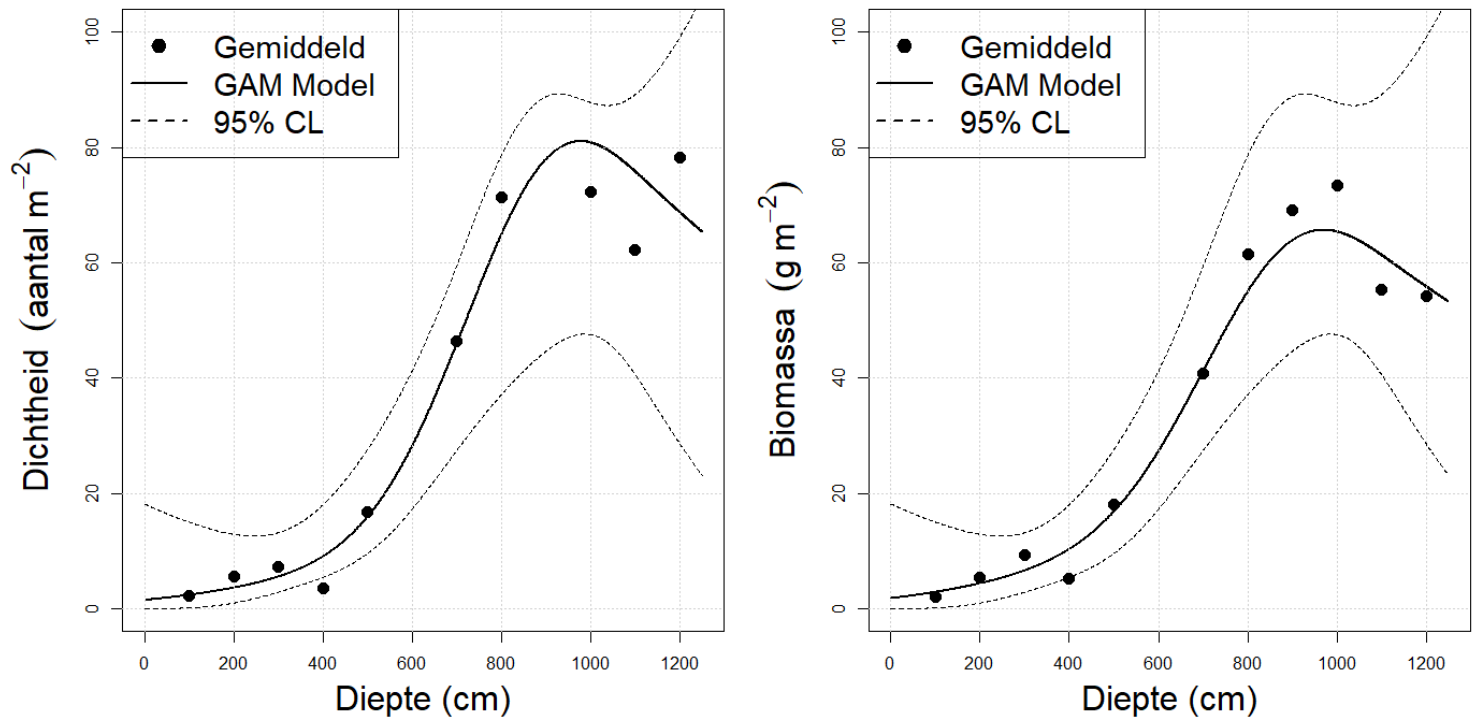

Figuur 25: Gemiddelde dichtheid (aantal $\mathrm{m}^{-2}$ ) en biomassa ( $\mathrm{g}$ versgewicht $\mathrm{m}^{-2}$ ) van de bodemdieren per diepteklasse (afgerond op hele meters beneden NAP) in 2019. De getrokken lijnen geven de resultaten van de GAM modellen als functie van de diepte. De stippellijnen geven de $95 \%$ betrouwbaarheidsgrenzen weer.

Omdat er veel overeenkomsten zijn in de patronen van dichtheid en biomassa van de bodemdieren met de diepte (Figuur 25) is alleen de biomassa verder uitgewerkt om de relatie met de diepte voor de verschillende transecten (zie Figuur 1 ) en over de jaren te onderzoeken. Uit de GAM modellen voor de verschillende transecten (Figuur 26) blijkt dat er niet voor ieder transect een significante relatie is met 
de diepte. De GAM regressies zijn hier ook gebaseerd op de vierdemachtswortel-getransformeerde biomassa data. Voor transecten 0, 7 en 8 was het model niet significant. Transecten 5 en 9 laten een optimum biomassa zien bij een diepte tussen de 7 en 10 meter. De overige transecten is er een toenemende trend met de waterdiepte.
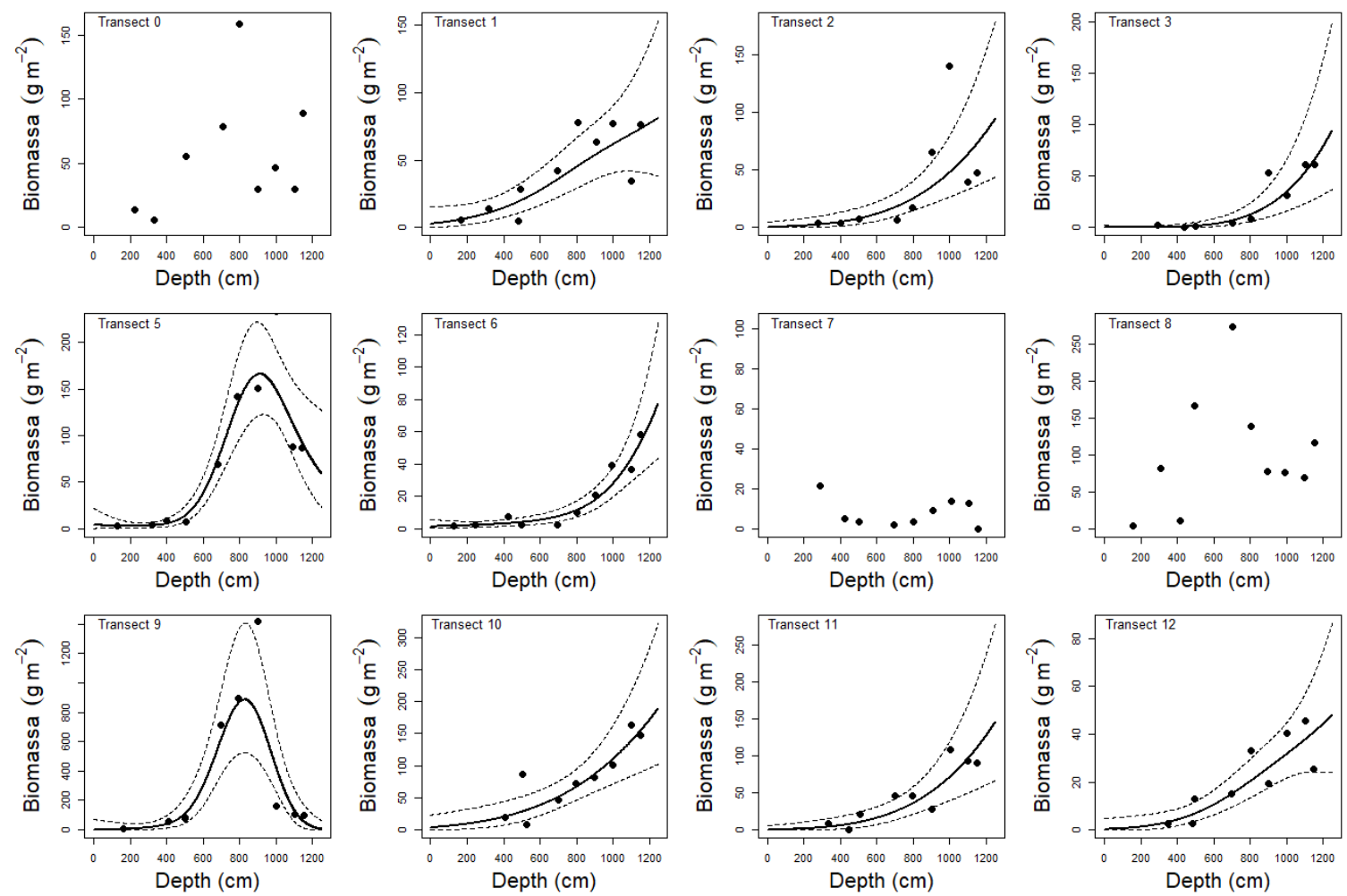

Figuur 26: Gemiddelde biomassa ( $\mathrm{g}$ versgewicht $\mathrm{m}^{-2}$ ) van de bodemdieren in 2019 per transect als functie van de waterdiepte. De getrokken lijn geeft het resultaat van het GAM model als functie van de diepte. De stippellijnen geven de 95\%-betrouwbaarheidsgrenzen weer. De ligging van de transecten zijn weergegeven in Figuur 1.

In Figuur 27 zijn de GAM modellen berekend voor de verschillende transecten over alle jaren (2010 tot en met 2019).Voor de transecten 7 en 8 (op de kop van de Zandmotor) is het GAM model niet significant ( $p>0.05$, Model 0 ). Op transect 5 is er een effect van de jaren, maar het patroon met de diepte is niet significant verschillend tussen de jaren (Model 2). Op dit transect is er een optimum biomassa tussen de 8 en 11 meter beneden NAP. De laagste biomassa is in 2010 gevonden en de hoogste biomassa in de jaren 2017 en 2019. Op de overige transecten is er een verschil in patroon met de diepte tussen de jaren, en ook het jaar-effect is verschillend per transect. 

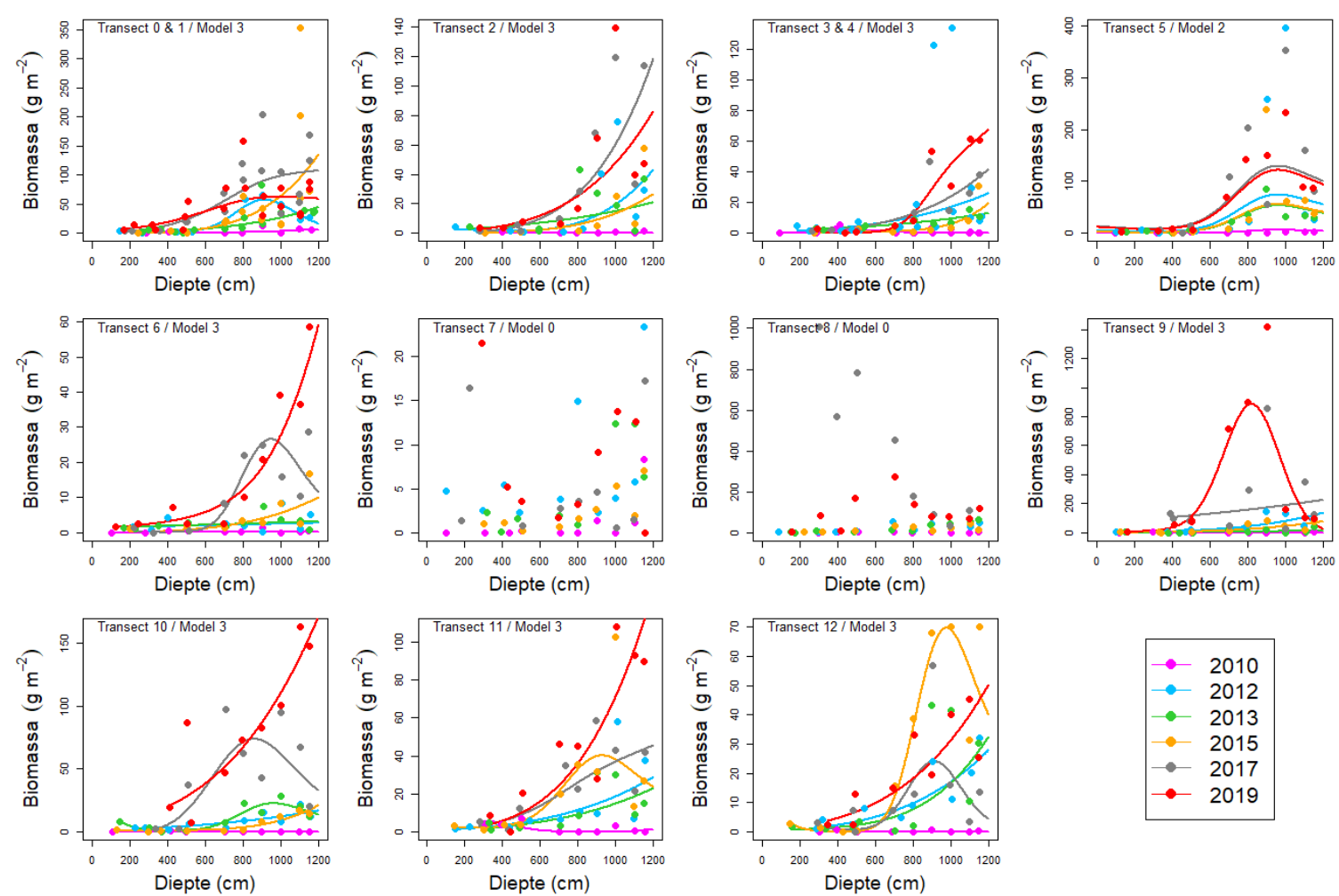

Figuur 27: Gemiddelde biomassa ( $\mathrm{g}$ versgewicht $\mathrm{m}^{-2}$ ) van de bodemdieren als functie van de waterdiepte voor de verschillende transecten. Met de kleuren zijn de GAM regressies voor de verschillende jaren weergegeven. Bij Model 0 was het GAM model niet significant $(p>0.05)$. Bij Model 2 (transect 5 ) is er wel een significant verschil tussen de jaren maar is er geen significant verschil in het patroon met de diepte. Bij Model 3 is er ook een significant verschil in het patroon met de diepte tussen de verschillende jaren.

\subsubsection{Relatie met sedimentsamenstelling}

In Figuur 28 is de dichtheid biomassa en aantal taxa van de schaaf bemonstering in 2019 uitgezet tegen de mediane korrelgrootte. $\mathrm{Er}$ is een tendens tussen het voorkomen van de bodemdieren en de sedimentsamenstelling (mediane korrelgrootte), maar deze relatie is minder sterk dan voor de Van Veen bemonstering (zie Figuur 48). Dit komt mogelijk omdat de schaaf over een groter gebied bemonsterd en niet exact op de locatie waar het sedimentmonster is genomen. In de Van Veen bemonstering is zowel het sediment monster als het benthos monster uit de zelfde hap genomen.
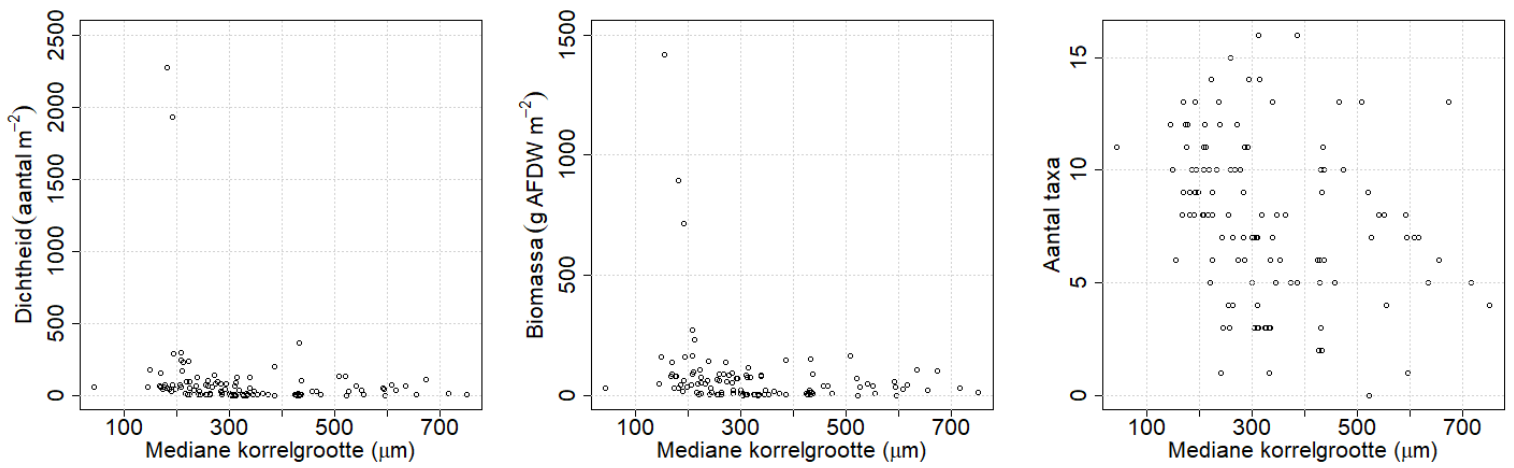

Figuur 28: Relatie tussen dichtheid, biomassa en aantal soorten per locatie op de verticale as en mediane korrelgrootte op de horizontale as voor de bemonstering met de bodemschaaf in 2019. De taxa Ensis spp., Mya arenaria, Lutraria lutraria en heremietkreeften zijn niet meegenomen in de biomassa. 


\subsubsection{Ruimtelijke verspreiding}

In Figuur 29 is de ruimtelijke verspreiding van de dichtheid, biomassa en het aantal soorten per monster voor het jaar 2019 weergegeven. In Bijlage 6 is de verspreiding (dichtheid) van een aantal dominante soorten voor de jaren 2010, 2012, 2013, 2015, 2017 en 2019 weergegeven. Ensis spp. die vooral in de jaren 2012 en 2013 in hoge dichtheden zijn aangetroffen, is daarna aanzienlijk afgenomen (Figuur 66). De meeste Ensis spp. zijn in 2019 aangetroffen in de diepere delen van transecten 1, 2, 9, 10, 11 en 12. De stevige strandschelp (Spisula solida) is sinds 2012 voornamelijk aangtroffen in de meest noordelijke transecten ( 9 tot en met 12), op een diepte van meer dan 5 meter beneden NAP (Figuur 73). Dit zijn ook relatief grove sedimenten Figuur 12). De halfgeknotte strandschelp (Spisula subtruncata) is in grote dichtheden aangetroffen op transect 9. Ook in 2017 sprong dat transect eruit in dichtheden van halfgeknotte strandschelpen (Figuur 74). Het zaagje (Donax vitatus) is duidelijk meer abundant in de jaren 2017 en 2019 dan in de jaren daarvoor (Figuur 65). In de zuidelijke transecten ( 0 tot en met 3 ) lijkt de soort een voorkeur te hebben voor de dieptes tussen de 5 en 8 meter onder NAP. De verspreiding van het nonnetje (Limecola balthica, Figuur 69) vertoont veel overeenkomsten met de verspreiding van het zaagje. De breedpootkrab (Portumnus latipes) is een karakteristieke soort voor de ondiepe brandingszone (Figuur 72). Op de dynamische kop van de Zandmotor (transecten 6, 7 en 8) komt de soort tot op grotere diepten voor dan op de andere transecten.

In Figuur 29 is nogmaals te zien dat over het algemeen de ondiepe delen langs het strand relatief arm zijn. De dichtheden en biomassa's nemen toe met de diepte. De hoogste biomassa's zijn aangetroffen op transect 9, in het bijzonder de stations 2019_085, 2019_086 en 2019_087, waar dichtheden van meer dan 2000 individuen per $\mathrm{m}^{2}$ en biomassa's van meer dan $700 \mathrm{~g} \mathrm{~m}^{2}$ zijn aangetroffen. Ook worden er relatief hoge biomassa's aangetroffen op transect 5, juist ten zuiden van de Zandmotor en de transecten 8 en 10, iets ten noorden van de Zandmotor. De dichtheden op de kop van de Zandmotor (transecten 6 en 7) zijn relatief laag.

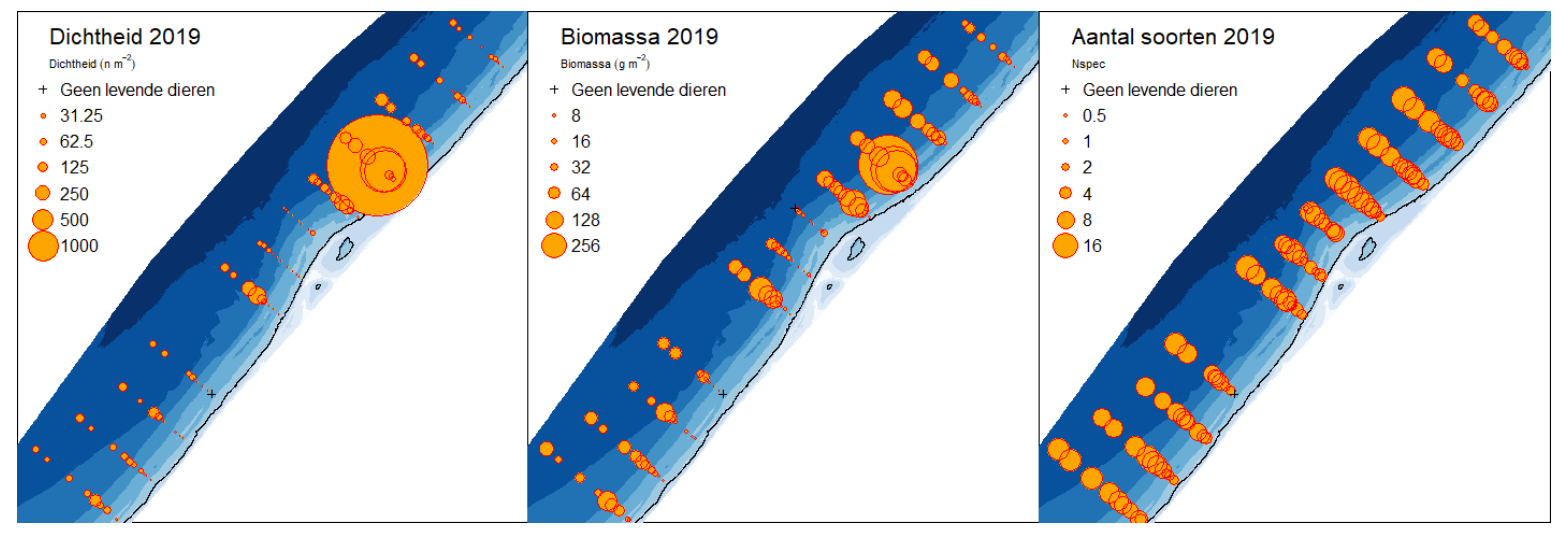

Figuur 29: Verspreidingskaart van de totale dichtheid (aantal $\mathrm{m}^{-2}$ ), biomassa ( $\mathrm{g}$ versgewicht $\mathrm{m}^{-2}$ ) en aantal soorten per station in de schaafbemonstering in 2019. Bij de biomassa zijn Ensis spp., otterschelpen, strandgapers en heremietkreeften niet meegenomen. Bij het plusje (station 2019_032) geeft aan dat er geen levende dieren zijn aangetroffen.

In Figuur 30 is de spreiding in dichtheden, biomassa en aantal soorten weergegeven voor de verschillende transecten. Ook in deze figuur is te zien dat de transecten 6 en 7, op de kop van de Zandmotor, relatief arm zijn, zowel wat betreft dichtheid en biomassa en het aantal soorten. De transecten 5, 8, 9 en 10 daarentegen zijn relatief rijk qua bodemdieren. 

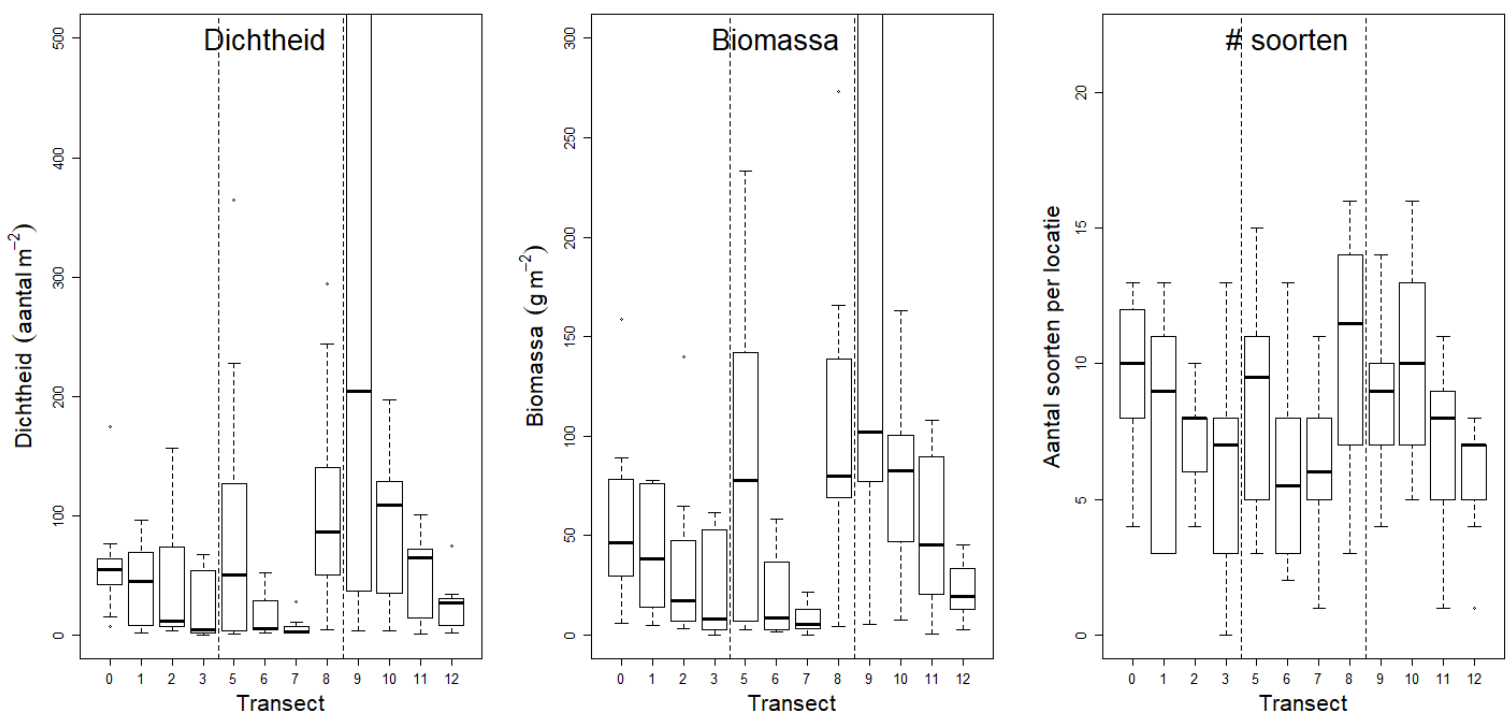

Figuur 30: Boxplots van de dichtheid (aantal $\mathrm{m}^{-2}$ ), biomassa ( $\mathrm{g}$ versgewicht $\mathrm{m}^{-2}$ ) en het aantal soorten per locatie in 2019 over de verschillende transecten van de meest zuidelijke (transect 0 ) naar het meest noordelijke (transect 12). De verticale stippellijnen geven de scheiding tussen de verschillende deelgebieden. Bij de biomassa biomassa zijn Ensis spp., otterschelpen, strandgapers en heremietkreeften niet meegenomen.

In Figuur 31 is zijn de ruimtelijke plaatjes van de biomassa in de bodemschaaf over alle jaren weergegeven. In de figuur is duidelijk te zien dat 2010 een relatief arm jaar was qua biomassa. In de jaren na de aanleg van de Zandmotor is te zien dat er vaak relatief hoge biomassa's zijn aangetroffen op net ten noorden van de Zandmotor (transecten 8 en 9) en ten zuiden van de Zandmotor (transecten 4 en 5).

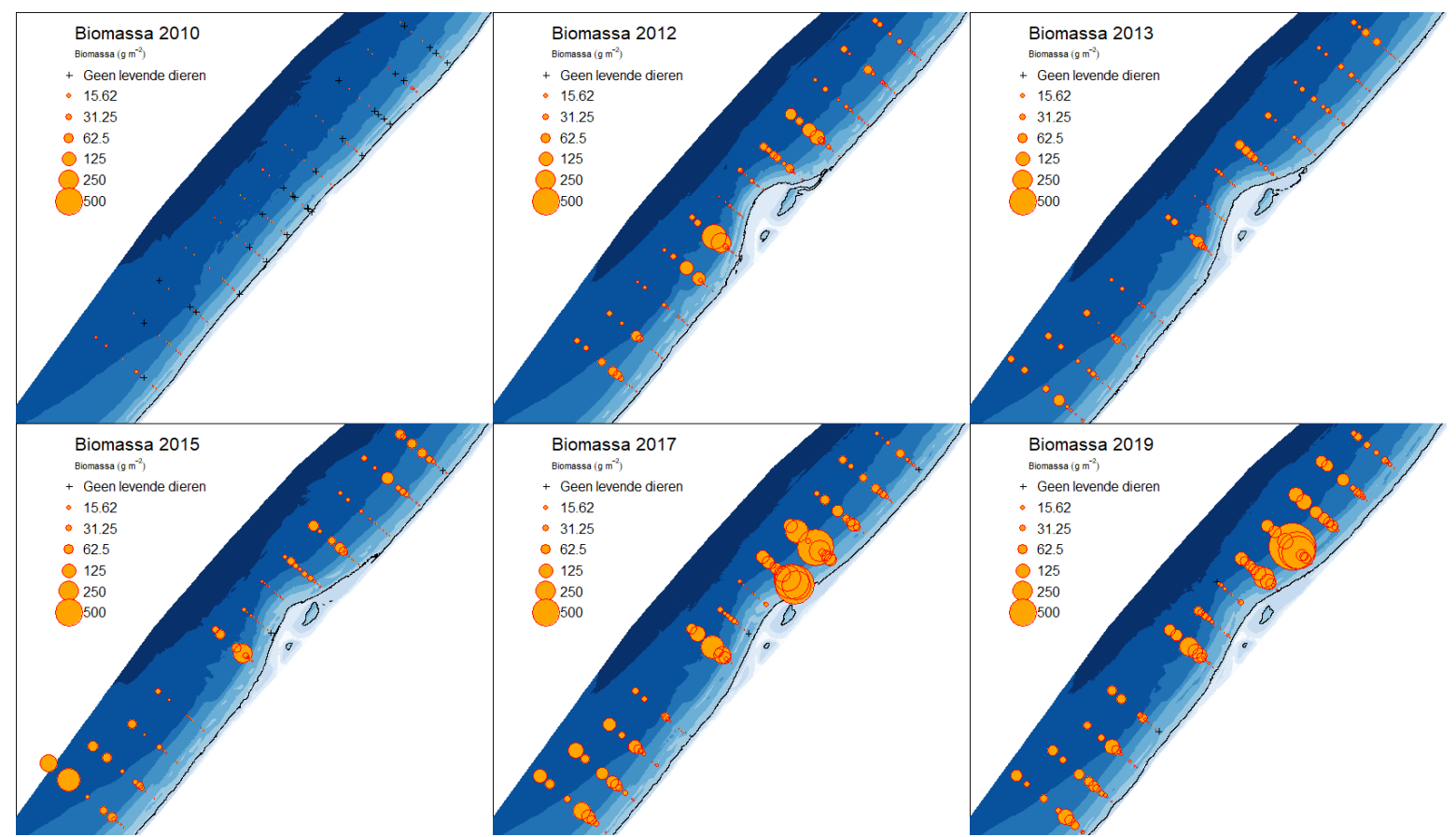

Figuur 31: Verspreidingskaarten totale biomassa bodemdieren in de schaaf ( $\mathrm{g}$ versgewicht $\mathrm{m}^{-2}$ ) voor de jaren 2010, 2012, 2013, 2015, 2017 en 2019. Bij de biomassa biomassa zijn Ensis spp., otterschelpen, strandgapers en heremietkreeften niet meegenomen. 


\subsubsection{Gemeenschapsanalyses}

In Figuur 32 is het resultaat van de clusteranalyse weergegeven voor de data (dichtheid) van de bodemschaaf uit 2019. De clusters zijn berekend op group averages en de significantie van de clusters is getoetst met een SIMPROF permutatie test $(a=0.05)$. Met behulp van deze test is het mogelijk om te toetsen of de verschillen in bodemdiersamenstelling tussen twee verschillende clusters zijn gebaseerd op toeval of niet. In Figuur 32 zijn de significante clusters aangegeven door middel van de zwarte lijnen. De clusters die aangegeven zijn met de rode lijnen zijn niet significant $(p>0.05)$. Dit wil zeggen dat de verschillen in bodemdiergemeenschap die zijn aangetroffen tussen deze clusters waarschijnlijk berust op toeval (variatie binnen de groep). De labels die zijn gebruikt geven het cluster weer.

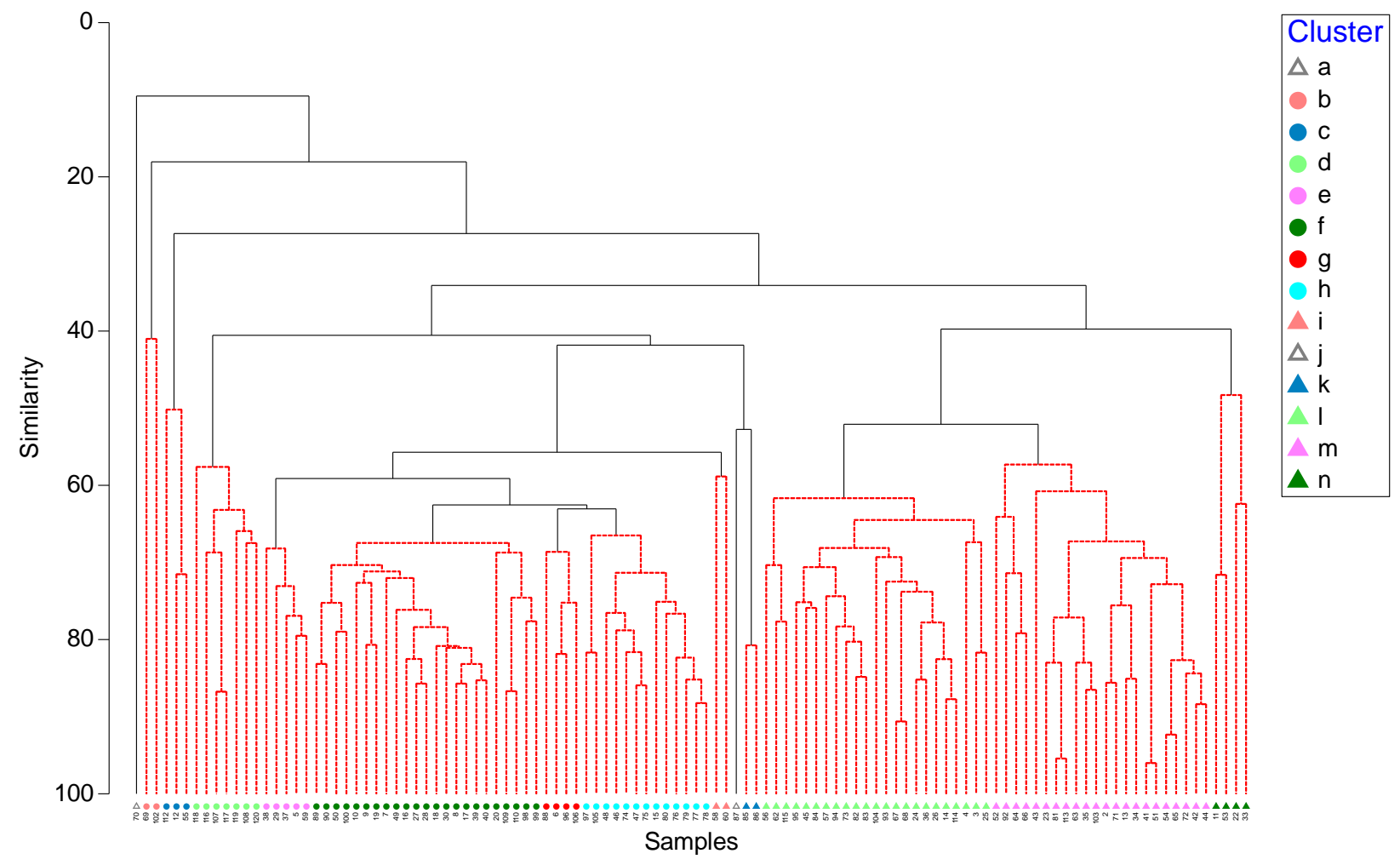

Figuur 32: Clusterdiagram van bodemdieren in de bodemschaaf in 2019. De zwarte lijnen geven de significante clusters (Simprof test, $\mathrm{p}<0.05$ ).

De clusteranalyse op basis van de data van de bodemschaaf in 2019 heeft geresulteerd in 14 significante clusters, waarvan twee clusters ( $a$ en $\mathrm{j}$ ) bestonden uit slechts een station (respectievelijk 2019_70 en 2019_87. De clusters I (23 stations) m (22 stations) en n (4 stations) liggen allemaal in de ondiepe zone (Figuur 33), waarbij de stations uit de clusters $m$ en $n$ iets ondieper liggen dan de stations uit cluster I. De clusters worden gekarakteriseerd door de aanwezigheid van de breedpootkrab (Portumnus latipes). In cluster $\mathrm{m}$ zijn er ook wat zaagjes (Donax vittatus) aanwezig en in cluster I meer zaagjes zijn aangetroffen, evanals andere scheldpieren zoals halfgeknotte strandschelp (Spisula subtruncata) en kleine heremietkreeften (Diogenes pugilator). De stations van cluster $\mathrm{f}$ ( 23 stations) liggen voornamelijk in de diepere delen van de transecten en zijn afwezig op de transecten 6, 7 en 8 op de kop van de Zandmotor. Dit cluster kenmerkt zich door de aanwezigheid van soorten als zaagje (Donax vittatus), halfgeknotte strandschelp (Spisula subtruncata) en de venusschelp (Chamelea striatula). Het cluster d (7 stations) is ruimtelijk geconcentreerd tot de twee meest noordelijke transecten (11 en 12). Dit gebied kenmerkt zich door de relatief grove sedimenten en kenmerkt zich door het voorkomen van een soort als de stevige strandschelp (Spisula solida, Figuur 73). Opvallend ruimtelijk geclusterd zijn ook de 13 stations van cluster h (Figuur 33). Deze bevinden zich voornamelijk op de transecten 5 en 8 


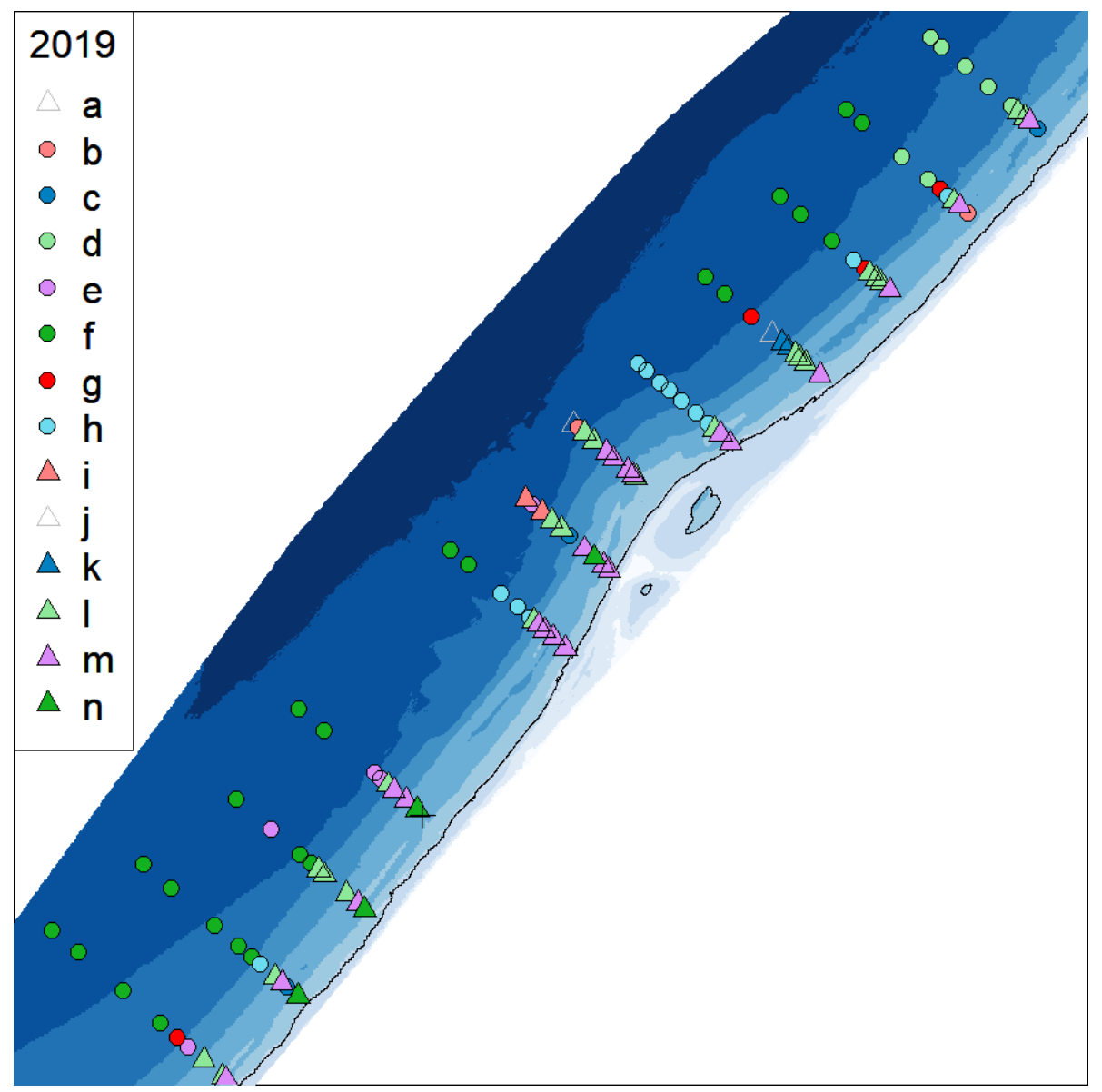

Figuur 33: Ruimtelijke verspreiding van de clusters uit de bodemschaaf in 2019

Dezelfde clusteranalyse is tevens uitgevoerd voor de jaren 2010, 2012, 2013, 2015 en 2017 afzonderlijk. De resultaten hiervan zijn gepresenteerd in Bijlage 7 (Figuur 75 tot en met Figuur 79).. De (ruimtelijke) patronen die zijn gevonden in 2019 komen overeen met de patronen die zijn gevonden in 2012, 2013, 2015 en 2017. Het patroon in 2010 echter was wel afwijkend. Ten eerste zijn er in 2010 slechts 4 clusters aangetroffen, wat wijst op een mindere ruimtelijke variatie in bodemdiergemeenschappen. Ook in 2010 was er, naast de diepte gradiënt in de clusters (cluster a in de ondiepe zone langs het strand) een kustlangse gradiënt. Zo namen de clusters $b$ en $d$ af, en het cluster c toe gaande van transect 1 naar transect 12 (Figuur 75).

In Figuur 34 is de nMDS plot van de data van de bodemschaaf uit 2019 weergegeven. De markers geven de clusters uit de clusteranalyse (Figuur 32) weer. In de figuur is duidelijk te zien dat de relatief ondiepe stations van de clusters $m$ en $n$ zich ook op de nMDS duidelijk onderscheiden van de overige clusters. Cluster $\mathrm{l}$ is een overgangscluster naar de dieper gelegen clusters $f, g$ en $h$ (hogere waarde op de vertikale as. Het cluster d, met de relatief grove sedimenten in het noorden van het onderzoeksgebied heeft een lagere waarde op de horizontale nMDS as. In Figuur 35 zijn de markers van de nMDS vervangen door taartdiagrammen voor kenmerkende soorten voor de verschillende clusters zoals de breedpootkrab (Portumnus latipes), de stevige strandschelp (Spisula solida), het zaagje (Donax vittatus) en de vensusschelp (Chamelea striatula).. In Figuur 36 ten slotte is de verspreiding van de dichtheden van deze soorten over het gebied rond de Zandmotor weergegeven. 


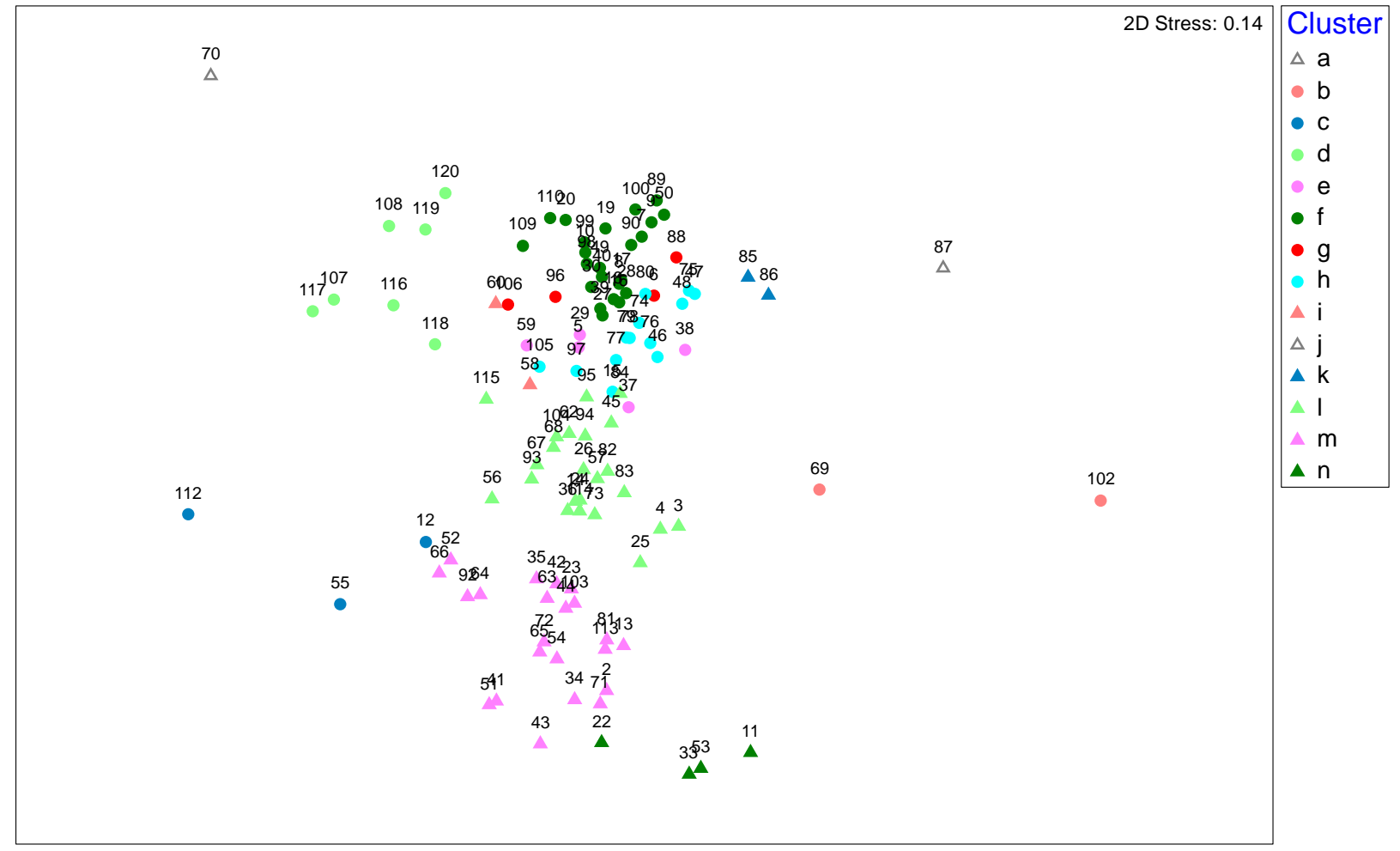

Figuur 34: nMDS plot van de gegevens van de bodemschaaf in 2019. De labels geven de nummers van de bemonsteringslocaties weer. De kleur van de markers geven de clusters uit de clusteranalyse Figuur 32.

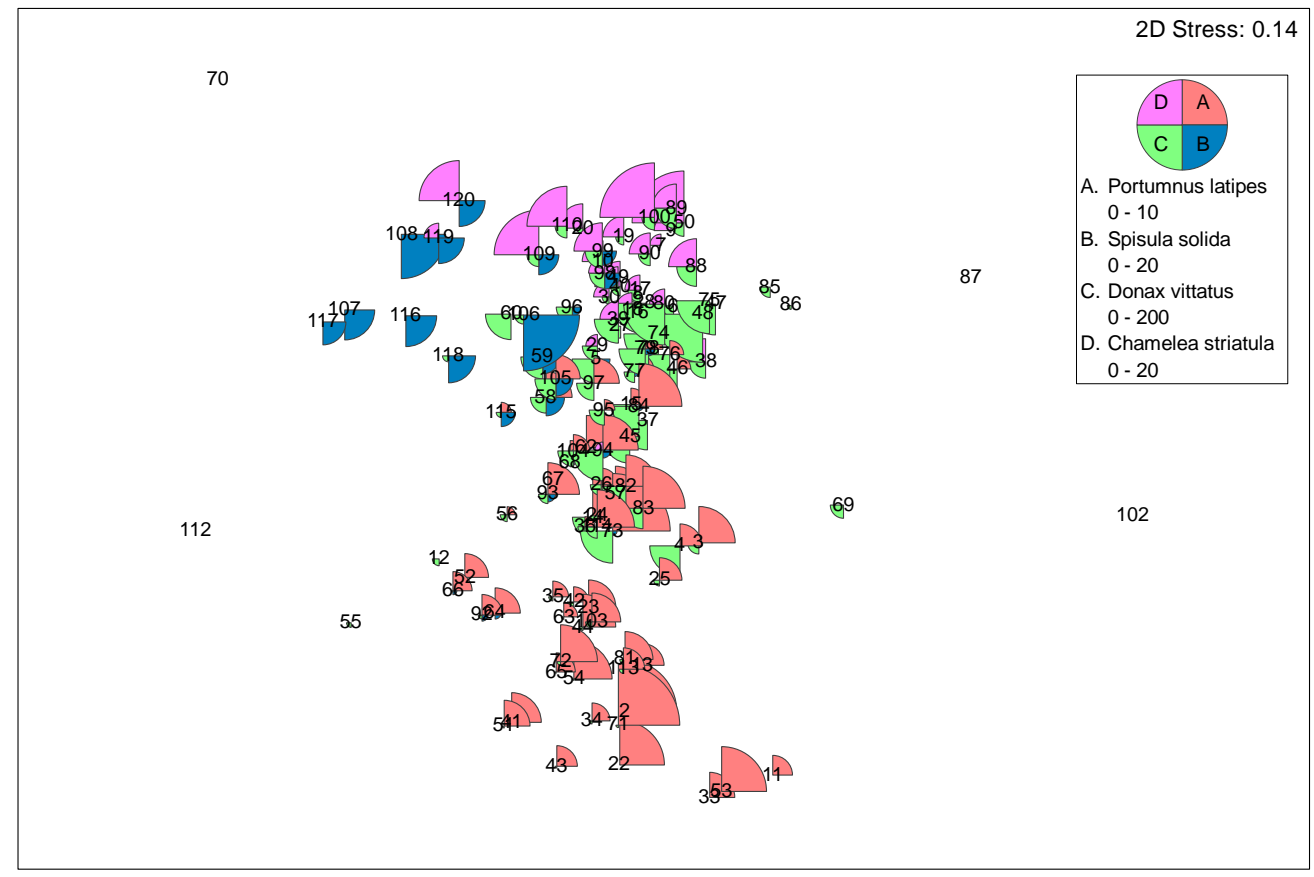

Figuur 35: nMDS plot van de gegevens van de bodemschaaf in 2019 (zie ook Figuur 34). De markers geven nu de relatieve dichtheid van een aantal karakteristieke soorten weer. De labels geven de nummers van de bemonsteringslocaties weer. 


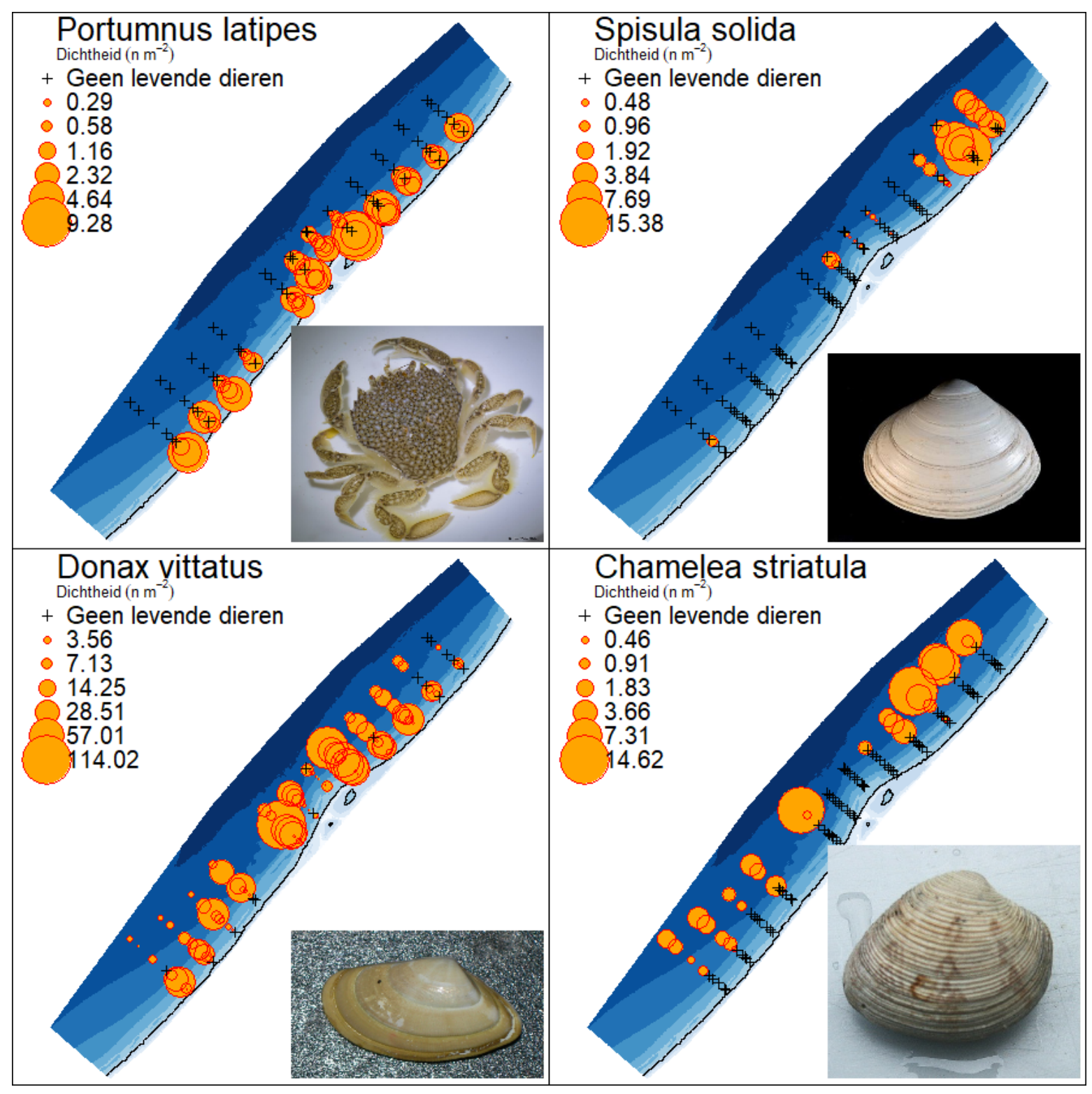

Figuur 36: Verspreiding van de dichtheden van de breedpootkrab (Portumnus latipes), halfgeknotte strandschelp (Spisula solida), zaagje (Donax vittatus) en de venusschelp (Chamelea striatula) uit de schaafbemonstering van 2019.

Om de ontwikkeling in de tijd te visualiseren zijn er niet-metrische MDS plots gemaakt op geaggregeerde data over alle jaren. De dichtheden zijn hiervoor gemiddeld per jaar en gebied (Zuid, Zandmotor, Noord, Figuur 37) en per jaar en dieptestratum (Figuur 38, Tabel 1). Voor alle gebieden is er een vergelijkbaar patroon over de tijd (2010 naar 2019). Het jaar 2010 wijkt hierbij het sterkst af van de overige jaren. Het jaar 2012 lijkt relatief uniform wat aangeeft dat er in dat jaar relatief weinig verschil is tussen de gebieden Zuid, Zandmotor en Noord. De verschillen tussen 2017 en 2019 zijn niet zo groot voor de deelgebieden Zandmotor en Zuid. In het deelgebied noord is de bodemdiergemeenschap in 2019 wel anders dan in 2017. Uit de figuur is af te leiden dat er een ontwikkeling in de bodemdiergemeenschap heeft plaatsgevonden in alle drie de deelgebieden en dat het de jaarlijkse verschillen groter zijn dan de verschillen tussen de drie deelgebieden. De bodemdiergemeenschap gaat steeds meer afwijken van de bodemdiergemeenschap die in 2010 is aangetroffen. Dit geldt voor alle drie de deelgebieden. Uit de figuur is duidelijk te zien dat de bodemdiergemeenschap in het onderzoeksgebied zich aan het ontwikkelen is na de aanleg van de Zandmotor. De gemeenschap heeft zich niet ontwikkeld naar de situatie van voor de aanleg (2010). 


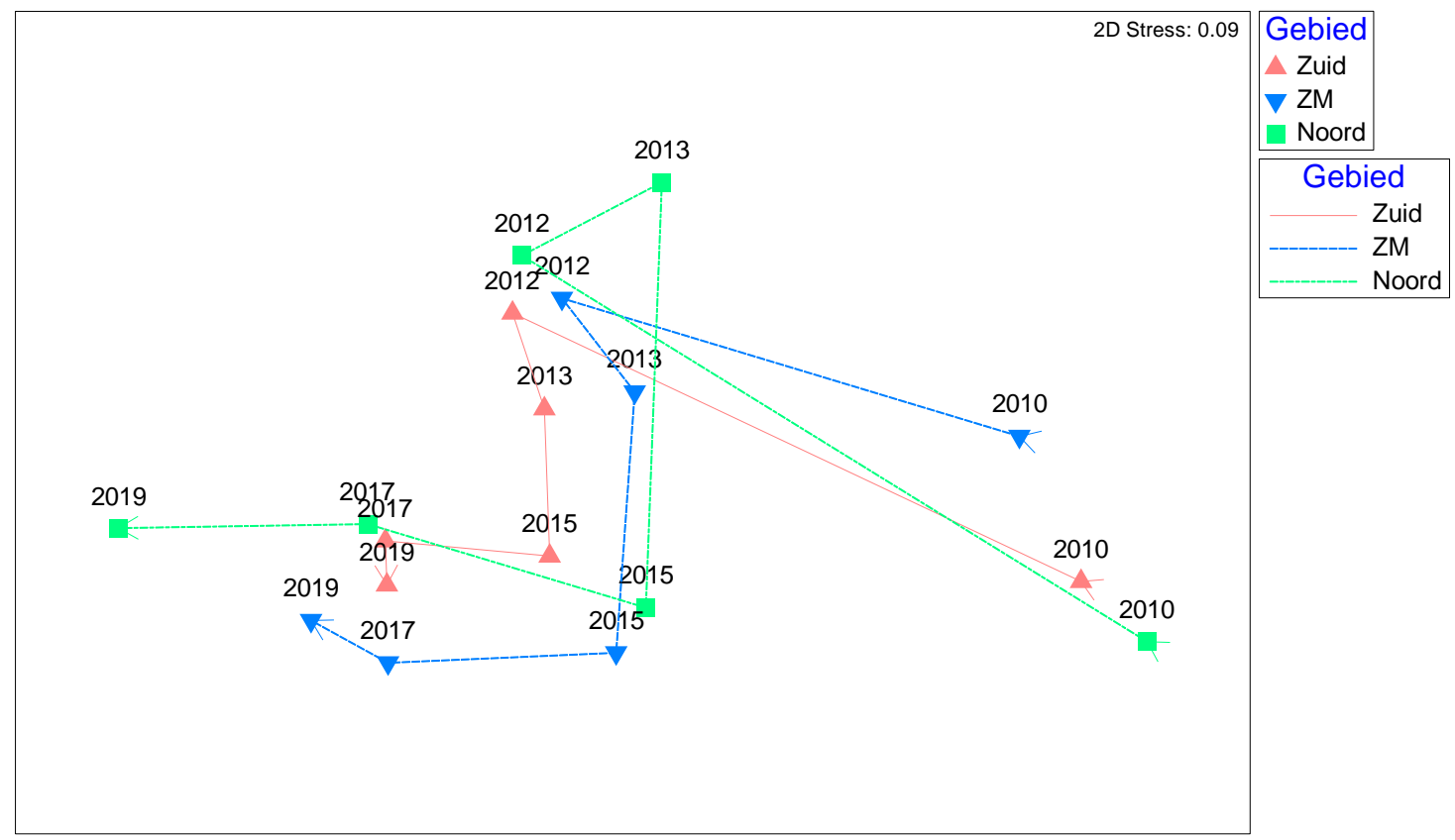

Figuur 37: nMDS plot van de ontwikkeling van de bodemdiergemeenschap over de tijd voor de drie verschillende deelgebieden (Zuid, Zandmotor en Noord). De afstand tussen de markers is een maat voor de dissimilariteit in de bodemdiersamenstelling.

In Figuur 38 is eenzelfde figuur gemaakt waarbij de data zijn geaggregeerd voor de factoren diepte en jaar. Met de kleuren zijn de jaren aangegeven en de getallen geven het dieptestratum aan (zie ook Tabel 1). Uit de figuur is duidelijk af te leiden dat er een diepte gradiënt zit in de bodemdiergemeenschap, waarbij de ondiepte stations een relatieve lage waarde op de horizontale as van het nMDS plot. Het jaareffect zit voornamelijk op de verticale as, waarbij er een duidelijke gradiënt is van 2010 naar 2019. Ook uit deze figuur blijkt dat de bodemdiergemeenschap zich nog steeds aan het ontwikkelen is en niet terug is in de situatie van 2010.

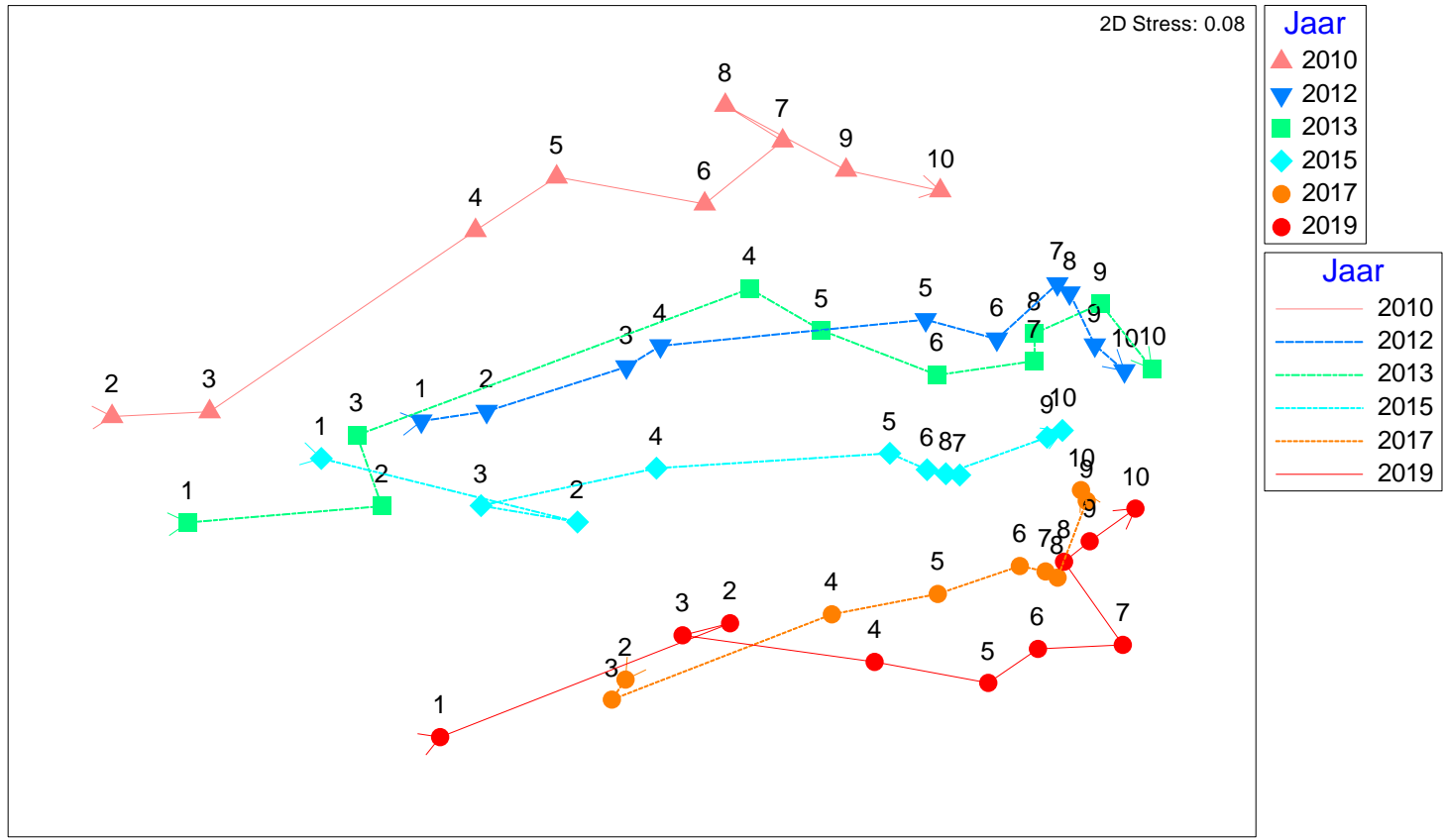

Figuur 38: nMDS plot van de ontwikkeling van de bodemdiergemeenschap als functie van de diepteklasse (zie Tabel 1) voor de verschillende jaren. De afstand tussen de markers is een maat voor de dissimilariteit in de bodemdiersamenstelling. 


\subsection{Van Veen bemonstering}

\subsubsection{Overzicht}

In totaal zijn er in 2019117 locaties bemonsterd met de Van Veen happer. De gemiddelde totale dichtheid aan bodemdieren in 2019 was 1711 individuen $\mathrm{m}^{-2}$ (st. dev. 6361 individuen $\mathrm{m}^{-2}$ ) en is op 2012 ( 2164 individuen $\mathrm{m}^{-2}$ ) na de hoogste gemiddelde dichtheid die is aangetroffen bij de monitoring op en rond de Zandmotor. In de jaren 2015 en 2017 was de gemiddelde dichtheid aan bodemdieren respectievelijk 870 en 1028 ind. $\mathrm{m}^{-2}$ (Figuur 39). De hoogste dichtheid (64 658 individuen $\mathrm{m}^{-2}$ ) is in 2019 aangetroffen op locatie 2019_087 (op dit station zijn ook de hoogste dichtheden met de schaaf aangetroffen) en bestaat voornamelijk uit Spisula subtruncata, maar ook Abra alba, Kurtiella bidentata en Mulinia lateralis kwamen op dit station voor in dichtheden van meer dan 5000 individuen $\mathrm{m}^{-2}$. De gemiddelde biomassa in 2019 was $8.71 \mathrm{~g} \mathrm{AFDW} \mathrm{m}^{-2}$ (st. dev. $20.49 \mathrm{~g} \mathrm{AFDW} \mathrm{m}^{-2}$ ). De taxa Ensis spp., Mya arenaria en Lutraria lutraria zijn daarbij niet meegerekend omdat vaak alleen de siphonen van deze soorten wordt aangetroffen in de monsters. De gemiddelde biomassa in 2019 was lager dan in 2017 (15.12 $\mathrm{g} \mathrm{AFDW} \mathrm{m}^{-2}$ ) maar hoger dan in de overige jaren. De maximale biomassa in 2019 is ook aangetroffen op locatie 2019_087 (195 g AFDW m²). Gemiddeld zijn er 15.5 taxa per station aangetroffen. Dit is iets minder dan in 2012 (15.9 taxa per station) maar meer dan in alle andere voorgaande jaren waar een bemonstering is uitgevoerd. Wat betreft gemiddelde dichtheid, biomassa en aantal taxa was 2010 het armste jaar (gemiddeld 9.6 taxa per station).
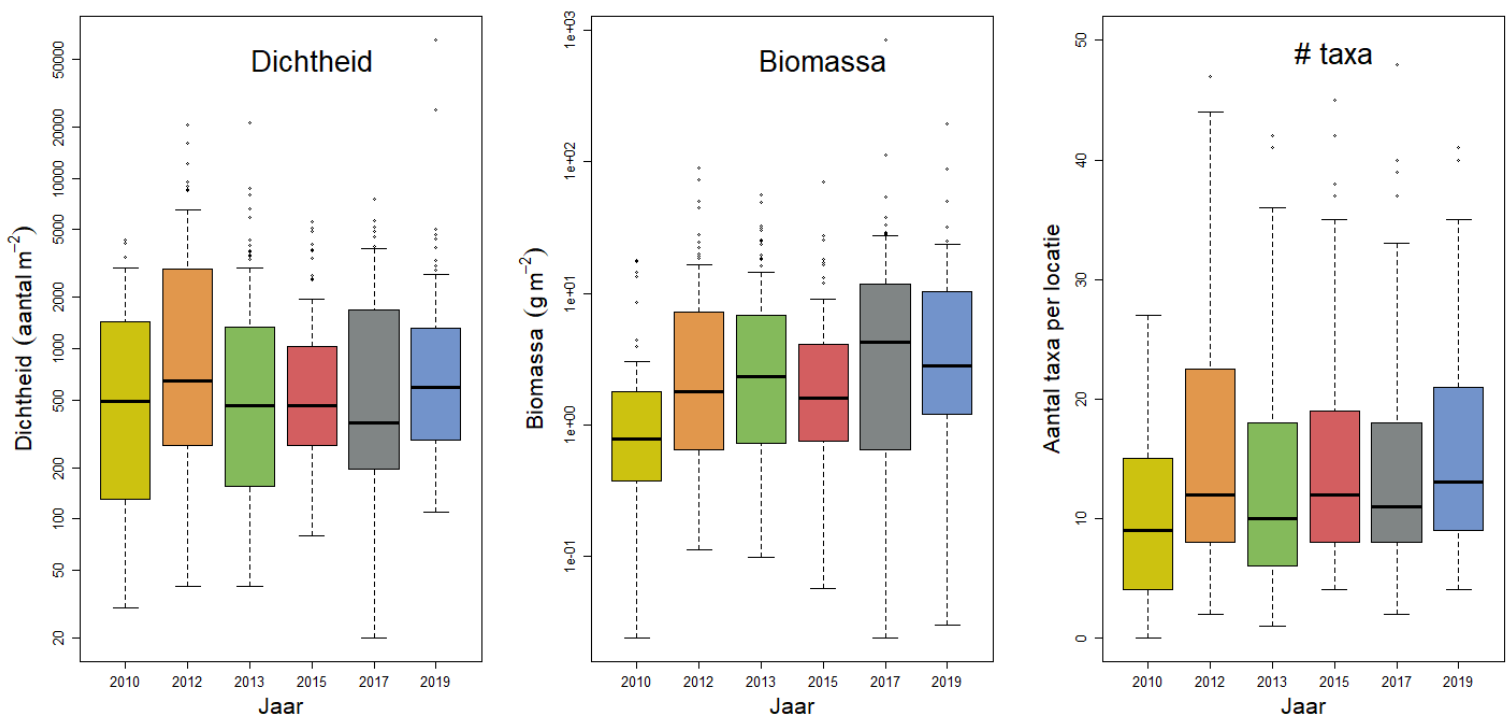

Figuur 39: Boxplots van dichtheid (aantal $\mathrm{m}^{-2}$ ), biomassa $\left(\mathrm{g} \mathrm{AFDW}^{-2}\right.$ ) en het aantal taxa per locatie over de jaren 2010 tot en met 2019 in de Van Veen bemonstering. Voor de biomassabepaling zijn Ensis, Mya arenaria en Lutraria lutraria niet meegenomen. Voor de overzichtelijkheid van de figuur zijn de $y$-assen voor dichtheid en biomassa op log-schaal weergegeven.

In totaal zijn er in 2019128 taxa aangetroffen in de Van Veen monsters. 17 van deze taxa zijn slechts op 1 station aangetroffen. 73 van de taxa zijn in 2019 op 5 of meer stations aangetroffen. In totaal zijn er over alle jaren 229 verschillende taxa aangetroffen in het onderzoeksgebied. Net als in 2017 zijn er in 2019 opvallend veel zaagjes (Donax vittatus) gevonden (43.6\% van de stations). Andere soorten die in 2019 veelvuldig zijn aangetroffen zijn de polychaeten Nephtys cirrosa, Nephtys hombergii en Spiophanes bombyx (Tabel 5). Soorten die in 2019 relatief weinig zijn aangetroffen zijn Ensis spp., Nephtys en Scoloplos armiger. 
Tabel 5: Percentage van de stations dat een taxon is aangetroffen in de Van Veen monsters. In de tabel zijn alleen de taxa aangegeven die in meer dan $25 \%$ van de monsters zijn aangetroffen.

\begin{tabular}{|c|c|c|c|c|c|c|c|}
\hline Taxon & 2010 & 2012 & 2013 & 2015 & 2017 & 2019 & Totaal \\
\hline Spiophanes bombyx & 38.7 & 64.2 & 54.6 & 55.8 & 46.7 & 65.8 & 55.7 \\
\hline Spio spp. & 53.2 & 61.7 & 40.2 & 65 & 44.2 & 48.7 & 52.5 \\
\hline Magelona johnstoni & 53.2 & 49.2 & 23.7 & 46.7 & 55 & 47.9 & 46.1 \\
\hline Capitella spp. & 50 & 45 & 22.7 & 29.2 & 34.2 & 47.9 & 37.6 \\
\hline Scolelepis (Scolelepis) squamata & 38.7 & 30.8 & 18.6 & 40.8 & 35.8 & 34.2 & 33.2 \\
\hline Fabulina fabula & 8.1 & 27.5 & 28.9 & 42.5 & 36.7 & 38.5 & 32.4 \\
\hline Spisula subtruncata & 14.5 & 29.2 & 30.9 & 31.7 & 39.2 & 39.3 & 32.2 \\
\hline Diogenes pugilator & 35.5 & 32.5 & 13.4 & 38.3 & 35 & 25.6 & 30.2 \\
\hline Scoloplos armiger & 25.8 & 37.5 & 42.3 & 32.5 & 25.8 & 15.4 & 29.9 \\
\hline Eteone spp. & 27.4 & 44.2 & 8.2 & 43.3 & 26.7 & 20.5 & 29.2 \\
\hline Nephtys spp. & 16.1 & 54.2 & 41.2 & 40.8 & 9.2 & 8.5 & 29.1 \\
\hline Limecola balthica & 1.6 & 28.3 & 15.5 & 37.5 & 30 & 43.6 & 28.6 \\
\hline Abra alba & 17.7 & 36.7 & 23.7 & 22.5 & 24.2 & 33.3 & 27.2 \\
\hline Magelona mirabilis & 33.9 & 20.8 & 26.8 & 44.2 & 25 & 12.8 & 26.7 \\
\hline Gastrosaccus spinifer & 1.6 & 21.7 & 5.2 & 54.2 & 30 & 27.4 & 25.9 \\
\hline
\end{tabular}

In Figuur 40 zijn de cumulatieve soortencurves weergegeven voor de verschillende jaren. In deze figuur is het totaal aantal taxa ( $y$-as) uitgezet tegen het aantal monsters ( $x$-as) en hiermee ven deze lijnen een indicatie voor het totaal aantal taxa dat kan worden aangetroffen binnen het onderzoeksgebied. In de figuur is duidelijk te zien dat er minder taxa aanwezig waren in 2010 (voor de aanleg van de Zandmotor) dan in de overige jaren. Het totaal aantal taxa in 2010 is geschat (eerste orde Jacknife) op 100. In 2019 is het totaal aantal taxa geschat op 150. De meeste taxa (186) zijn geschat voor het jaar 2017. De verhouding tussen het totaal aantal taxa en het gemiddeld aantal taxa per station en het is een maat voor de variatie tussen de stations en daarmee de ruimtelijke heterogeniteit in bodemdieren. Deze verhouding is het hoogst in de jaren 2013 en 2017 (respectievelijk 14.4 en 13.1) en het laagst in de jaren 2010 (10.4), 2012 (10.1) en 2019 (9.6).

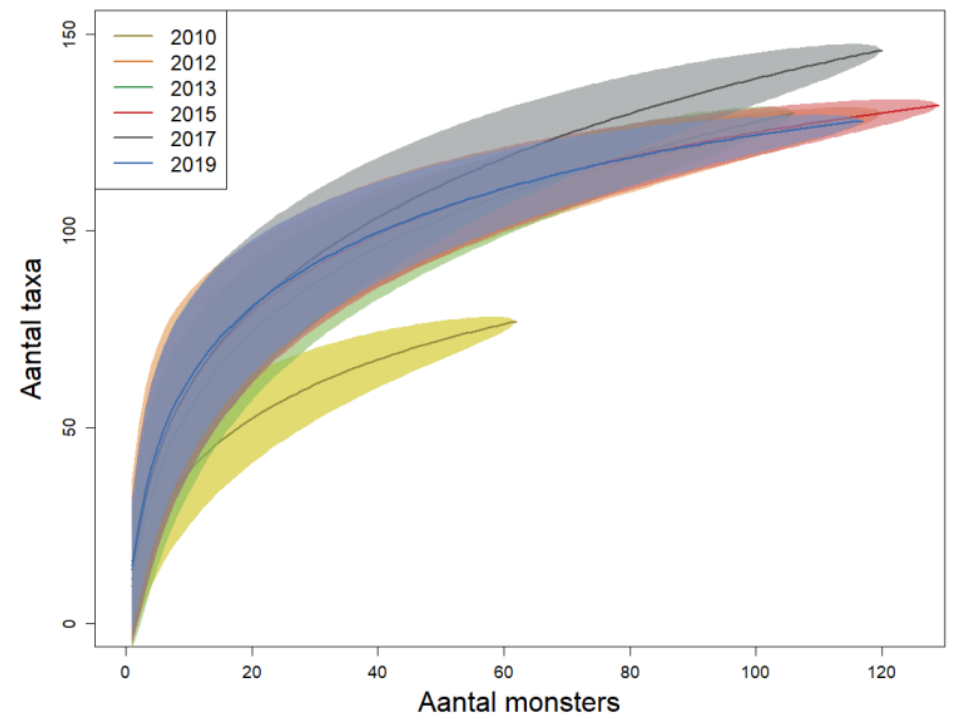

Figuur 40: Soorten-accumulatie plots voor de verschillende jaren. Op de y-as staan het aantal taxa weergegeven als functie van het aantal monsters ( $x$-as). De lijnen geven de gemiddelde waarde aan (eerste orde Jacknife), en de gekleurde band geeft de standaard deviatie aan. 
De halfgeknotte strandschelp (Spisula subtruncata) en het zaagje (Donax vittatus) waren in 2019 de meest dominante soorten op basis van de dichtheid (gemiddeld respectievelijk 228 en 230 individuen $\mathrm{m}^{-2}$ )(Figuur 41). Ook de schelpdieren witte dunschaal ( $A b r a$ alba) en tweetandsschelpje (Kurtiella bidentata) waren relatief dominant met gemiddelde dichtheden van meer dan 100 individuen $\mathrm{m}^{-2}$. Opvallende nieuwkomer is de Amerikaanse strandschelp (Mulinia lateralis). Deze nieuwe exoot (Craeymeersch et al., 2019) is in 2019 gevonden op 9.4\% van de stations bij de Zandmotor en had een gemiddelde dichtheid van 58 individuen $\mathrm{m}^{-2}$. De halfgeknotte strandschelp (Spisula subtruncata) was in 2019 de meest dominante soort op basis van biomassa (gemiddeld $2.17 \mathrm{~g} \mathrm{AFDW} \mathrm{m}^{-2}$ ), gevolgd door zaagje (Donax vittatus, $1.14 \mathrm{~g} \mathrm{AFDW} \mathrm{m}^{-2}$ ) en het nonnetje (Limecola balthica, $0.92 \mathrm{~g} \mathrm{AFDW} \mathrm{m}^{-2}$ ).

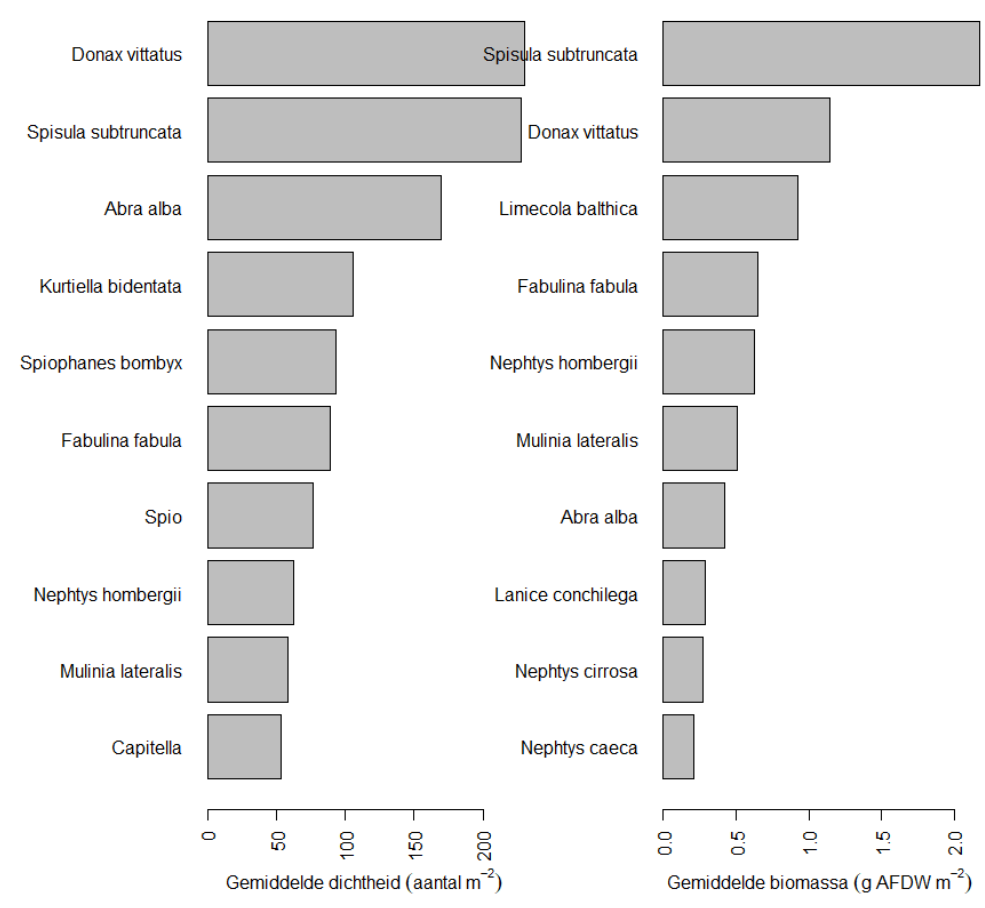

Figuur 41: Gemiddelde dichtheden en biomassa's van de 10 meest dominante soorten bij de bemonstering met de Van Veen happer in 2019.

In Figuur 42 is te zien dat in de 2010 twee soorten (Ensis spp. en de borstelworm Magelona johnstoni) verantwoordelijk waren voor meer van 50\% van de totale dichtheid die is aangetroffen. In 2015 was dit meer verspreidt en zijn er 7 soorten die samen $50 \%$ van de totale dichtheid bepalen. Wat betreft biomassa springt 2017 eruit en zijn er drie soorten schelpdieren, de halfgeknotte strandschelp, (Spisula subtruncata), zaagje (Donax vittatus) en rechtsgestreepte platschelp (Fabulina fabula) verantwoordelijk voor meer dan $75 \%$ van de totale biomassa. Let op dat in deze figuur de soorten Ensis spp., Mya arenaria en Lutraria lutraria niet zijn meegenomen omdat van deze soorten vaak alleen de siphonen worden aangetroffen in de monsters. 

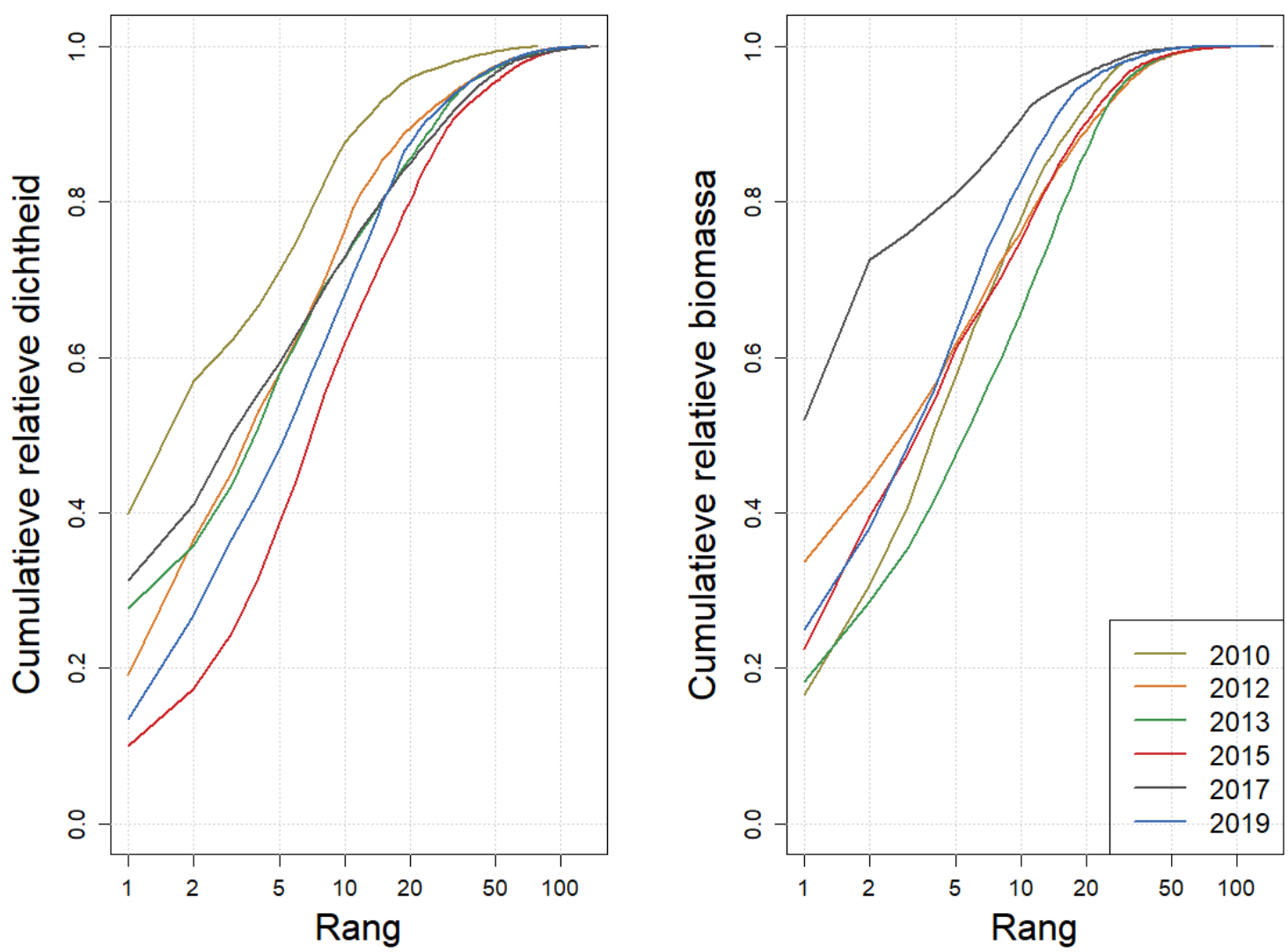

Figuur 42: Cumulatieve relatieve dichtheid (links) en de cumulatieve relatieve biomassa (rechts) als functie van de rangorde voor de jaren 2010 tot en met 2019. De soorten Ensis spp., Mya arenaria en Lutraria lutraria zijn niet meegenomen in de biomassa (rechter figuur).

In Figuur 43 is te zien dat vooral de dichtheden van de soorten zaagje (Donax vittatus), tweetandsschelpje (Kurtiella bidentata), halfgeknotte strandschelp (Spisula subtruncata), gewone zandzager (Nephtys hombergii), witte dunschaal (Abra alba) en rechtsgestreepte platschelp (Fabulina fabula) in 2019 hoger waren dan gemiddeld over de voorgaande jaren (periode 2010 - 2017). Soorten als Ensis spp. en de polychaeten Microphthalmus similis, Scoloplos armiger, Nephtys en Magelona johnstoni kwamen daarentegen in relatief lage dichtheden voor in 2019. In vergelijking met 2017 is vooral de toename van het tweetandsschelpje (Kurtiella bidentata), zaagje (Donax vittatus) en de halfgeknotte strandschelp (Spisula subtruncata) en de afname van de polychaeten Scoloplos armiger en Magelona johnstoni opvallend. De nieuwkomer, de Amerikaanse strandschelp (Mulinia lateralis) is in de figuur niet te zien omdat deze qua dichtheid niet behoort tot de 20 meest dominante soorten. 

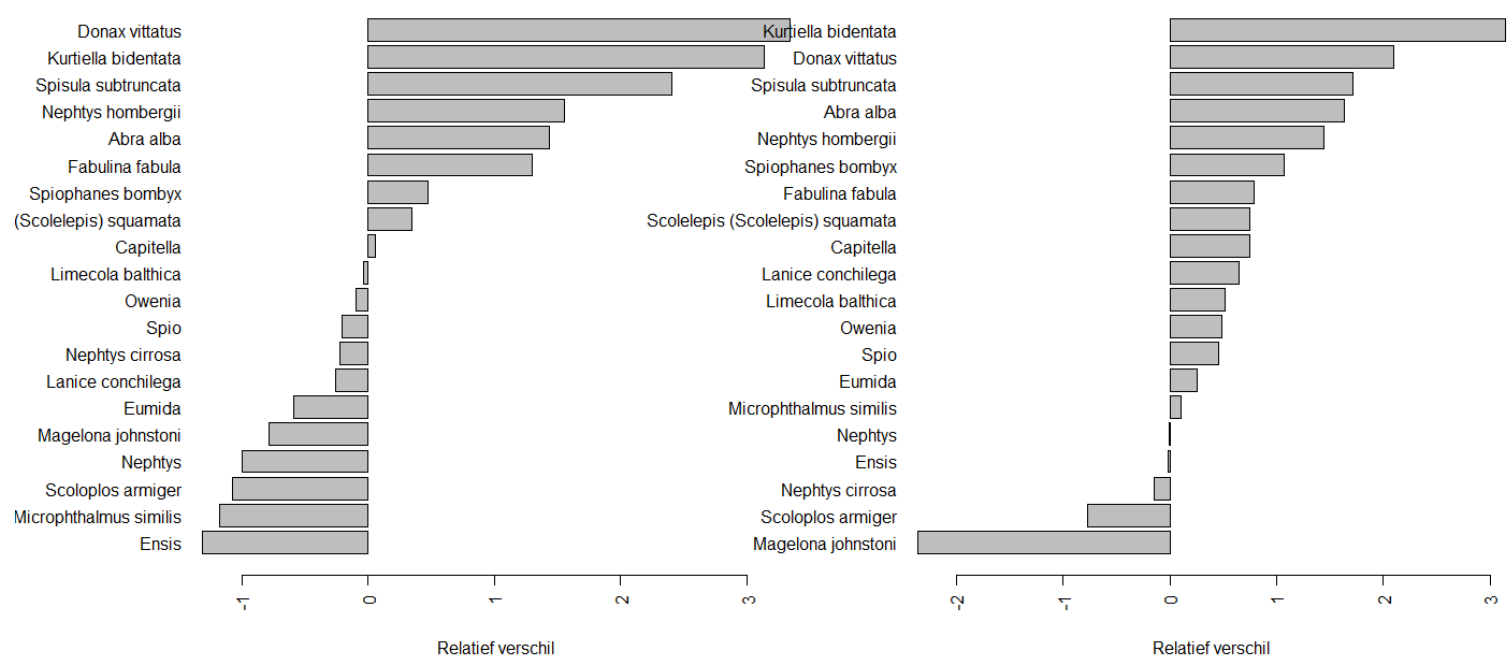

Figuur 43: Relatieve veranderingen in gemiddelde dichtheden van de 20 meest dominante soorten qua dichtheid in 2019. In de linker figuur is de gemiddelde dichtheid in 2019 vergleken met de gemiddelde dichtheid over de periode 2010 - 2017. Het verschil in gemiddelde dichtheid tussen 2019 en 2017 is in de rechter figuur weergegeven. De verschillen zijn gewogen naar de gemiddelde dichtheid per soort over alle jaren.

\subsubsection{Relatie met waterdiepte}

In Figuur 44 is te zien dat er een duidelijk effect is van diepte op zowel de dichtheid, biomassa als het aantal taxa aangetroffen in de Van Veen monsters. De dichtheid en biomassa neemt toe bij dieptes van meer dan 5 meter beneden NAP. Het aantal taxa per monster neemt toe vanaf den diepte van meer dan 5 meter beneden NAP.
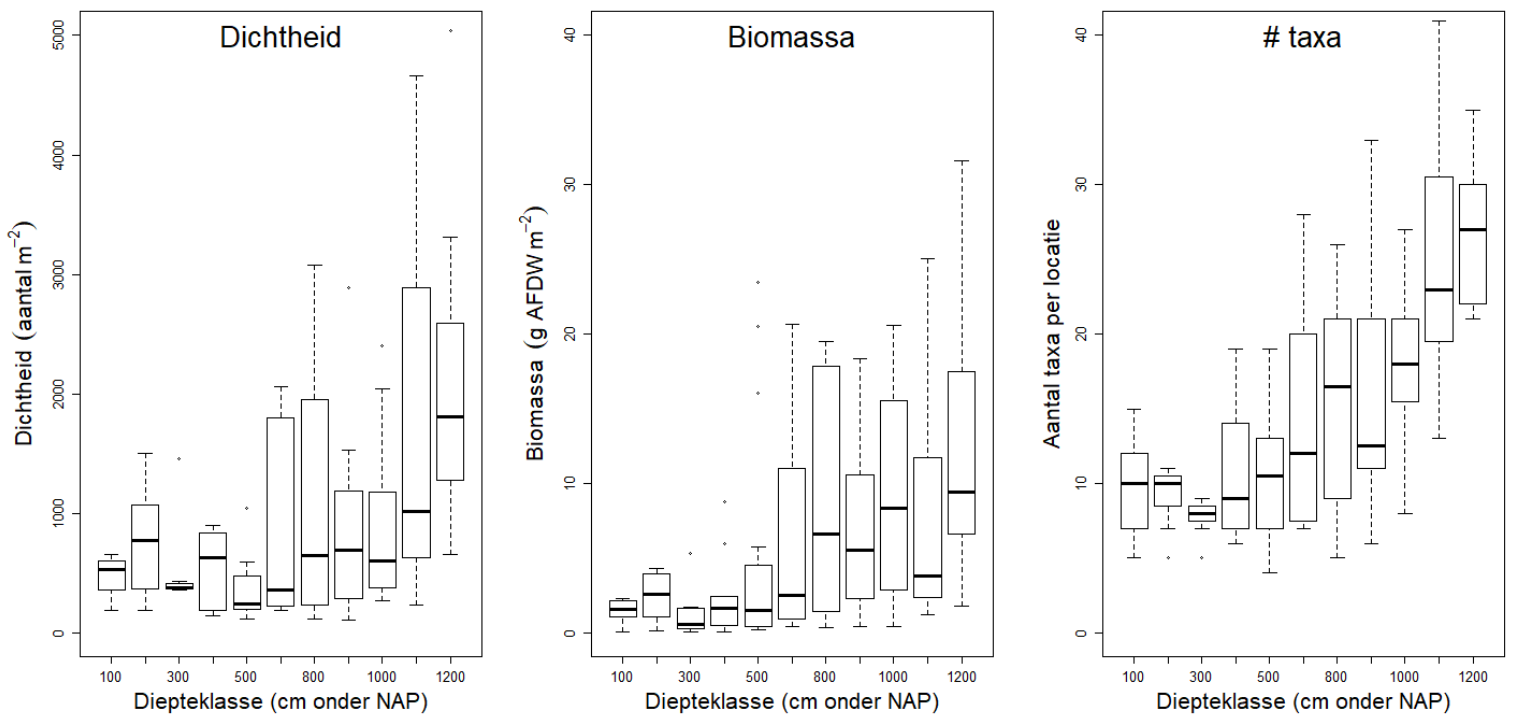

Figuur 44: Boxplots van dichtheid (aantal $\mathrm{m}^{-2}$ ), biomassa $\left(\mathrm{g} \mathrm{AFDW} \mathrm{m}^{-2}\right.$ ) en aantal taxa in de Van Veen monsters in 2019 als functie van de waterdiepte. De soorten Ensis spp., Mya arenaria en Lutraria lutraria zijn niet meegenomen in de biomassa. Uitschieters zijn in de figuur ziet zichtbaar.

Hetzelfde is ook te zien in het GAM-model van de dichtheid en biomassa als functie van de waterdiepte (Figuur 45). Voor de overzichtelijkheid zijn de punten die in de figuur zijn weergegeven zijn de gemiddelde waarden per diepteklasse. Vanzelfsprekend is het GAM model gebaseerd op de individuele metingen (117 locaties). De figuur laat zien dat zowel de gemiddelde dichtheid als de biomassa toeneemt vanaf waterdieptes dieper dan 6 meter beneden NAP. In Figuur 46 zijn de GAM modellen 
geplot voor de verschillende transecten. Deze analyse is alleen voor de dichtheid geplot omdat daarbij alle soorten zijn meegenomen. De plots voor de biomassa geven vergelijkbare resultaten. De relatie tussen de dichtheid en de waterdiepte is niet significant voor alle transecten. Alleen op de transecten 3,5 en 10 is het GAM model significant $(p<0.05)$. Op enkele van de overige transecten lijkt er wel een positieve trend te zijn met de waterdiepte, maar vanwege de variatie en het beperkt aantal monsters per transect $(\max 10)$ is het GAM-model hier niet significant.
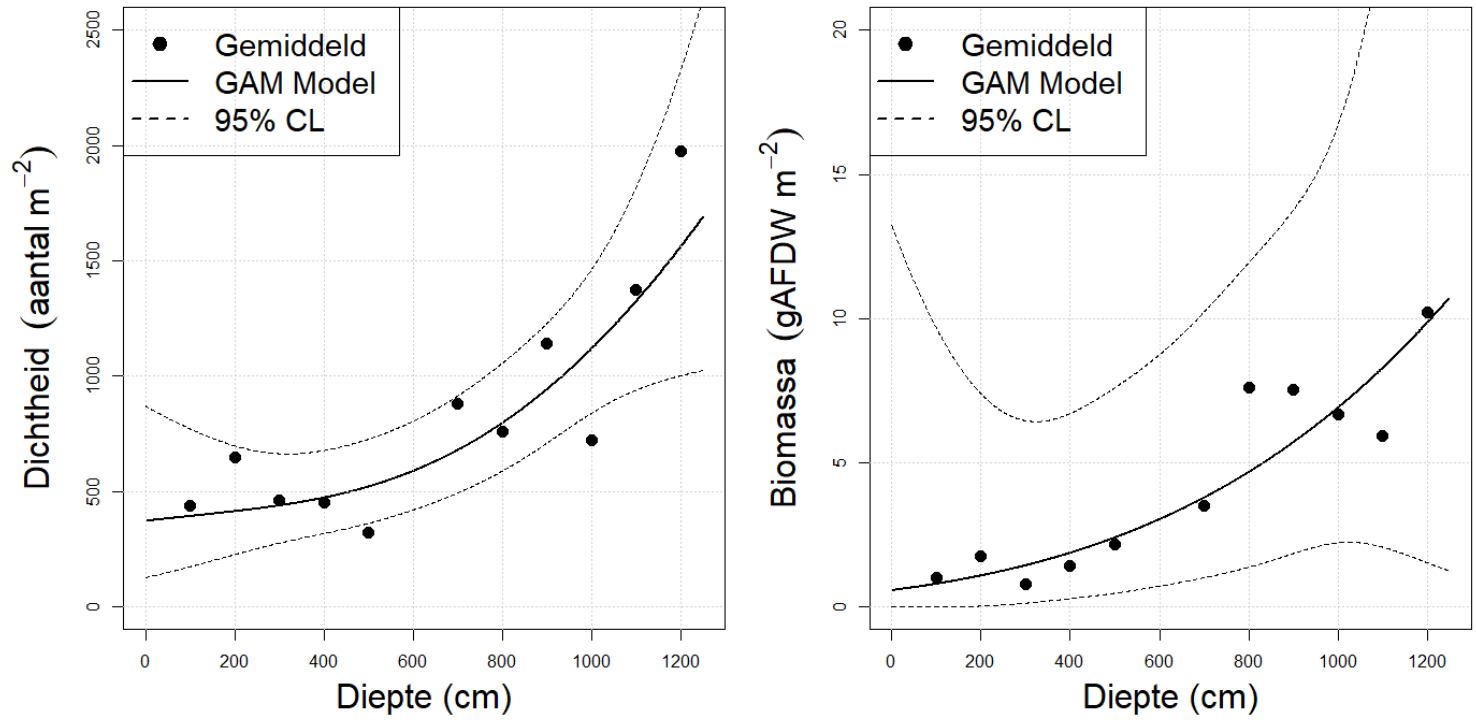

Figuur 45: Dichtheid (aantal $\mathrm{m}^{-2}$ ) als functie van de diepte (centimeter beneden NAP) van het benthos verzameld met de Van Veen happer in 2019. getrokken lijn geeft het resultaat van het GAM model als functie van de diepte en de stippellijnen geven de $95 \%$-betrouwbaarheid intervallen weer. Het model is gefit op individuele metingen, voor de overzichtelijkheid geven de punten de geaggregeerde data weer.
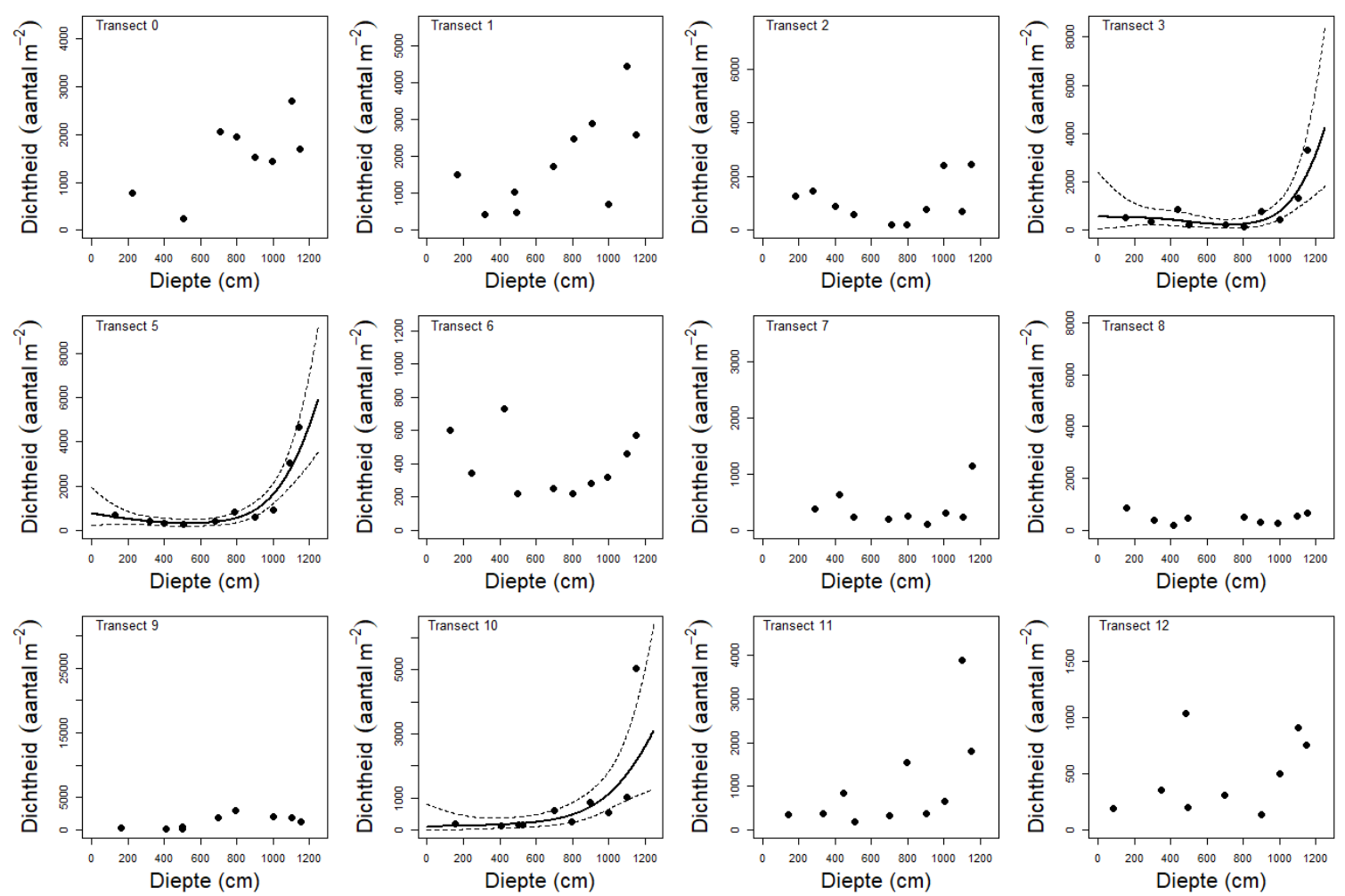

Figuur 46: GAM regressiemodellen voor de dichtheid van bodemdieren in de Van Veen bemonstering als functie van de waterdiepte ( $\mathrm{cm}$ beneden NAP) voor de 12 transecten. Alleen de significante GAM modellen zijn geplot. 
In Figuur 47 zijn de GAM modellen gepresenteerd voor alle jaren (2010 tot en met 2019) met jaar als co-variabele. Vooral in de meest zuidelijke transecten ( 0 tot en met 5 ) is er een duidelijk effect van de jaren, waarbij vooral 2012 afweek van de overige jaren op basis van hogere dichtheden over de hele diepterange. Op de overige transecten is er geen significant verschil tussen de jaren en op transect 7 is het GAM model niet significant.
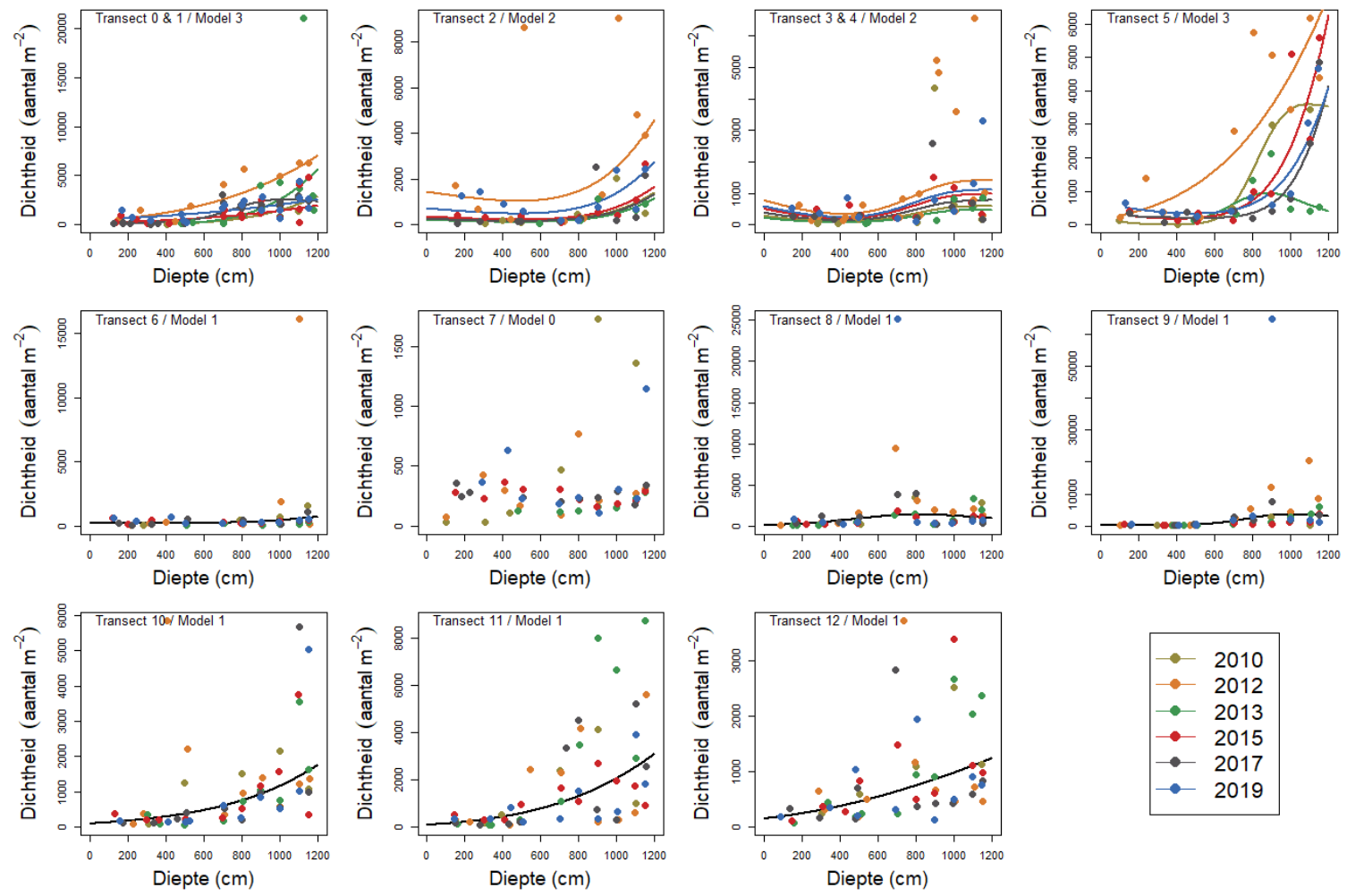

Figuur 47: GAM modellen van dichtheid bodemdieren (aantal $\mathrm{m}^{-2}$ ) als functie van de diepte ( $\mathrm{cm}$ beneden NAP) met jaar als factor voor de verschillende transecten. Bij Model 1 (getrokken zwarte lijnen) is er geen significant verschil tussen de jaren. Bij model 2 is er wel een significant verschil tussen de jaren, maar is er geen verschil in het patroon met de diepte. Bij model 3 is er ook een significant verschil in het patroon met de diepte tussen de verschillende jaren. Bij Model 0 is er geen significante relatie.

\subsubsection{Relatie met sedimentsamenstelling}

In Figuur 48 is de dichtheid biomassa en aantal taxa van de Van Veen bemonstering in 2019 uitgezet tegen de mediane korrelgrootte. Er is een duidelijke relatie tussen het voorkomen van de bodemdieren en de sedimentsamenstelling (mediane korrelgrootte). De hoogste biomassa's en dichtheden zijn aangetroffen bij een mediane korrelgrootte van minder van $300 \mu \mathrm{m}$. zoals eerder is aangetoond (Figuur 11) is de mediane korrelgrootte ook sterk gerelateerd met de waterdiepte en daarmee met andere co-variabelen zoals golfwerking en stroming. 

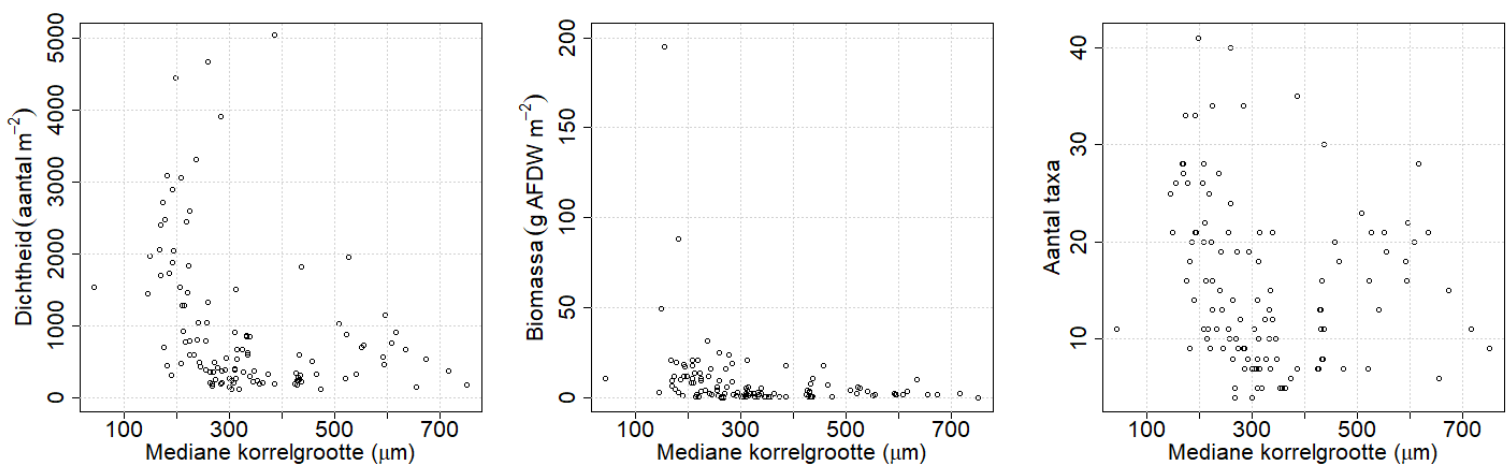

Figuur 48: Relatie tussen dichtheid, biomassa en aantal soorten per locatie op de verticale as en mediane korrelgrootte op de horizontale as voor de Van Veen bemonstering in 2019. De y-as van dichtheid is afgekapt bij 5000 individuen $\mathrm{m}^{-2}$. Twee waarden waren aanzienlijk hoger (65 000 en 25000 individuen per $\mathrm{m}^{-2}$ ). De soorten Ensis spp., Mya arenaria en Lutraria lutraria zijn niet meegenomen in de biomassa.

\subsubsection{Ruimtelijke verspreiding}

In Figuur 49 is ook weer duidelijk te zien dat er twee locaties uit springen met een zeer hoge dichtheid aan bodemdieren. De hoogste dichtheid is aangetroffen op locatie 2019_087 met 64658 individuen m 2 (biomassa $195 \mathrm{~g} \mathrm{AFDW} \mathrm{m}^{-2}$ ). De op een-na hoogste dichtheid is aangetroffen op locatie 2019_075 op de kop van de Zandmotor (25 140 individuen $\mathrm{m}^{-2}$ ) en bestaat voornamelijk uit jonge zaagjes (Donax vittatus, 24090 individuen $\mathrm{m}^{-2}$ ). Het station 2019_086 heeft na 2019_087 de hoogste biomassa aan bodemdieren ( $88 \mathrm{~g} \mathrm{AFDW} \mathrm{m}^{-2}$ ). De meeste stations op de kop van de Zandmotor (transecten 6, 7 en 8 ) bevatten een relatief lage dichtheid aan bodemdieren. In het aantal taxa per station lijkt er geen verschil tussen de transecten. Er is wel een trend met de waterdiepte (zie ook Figuur 44).

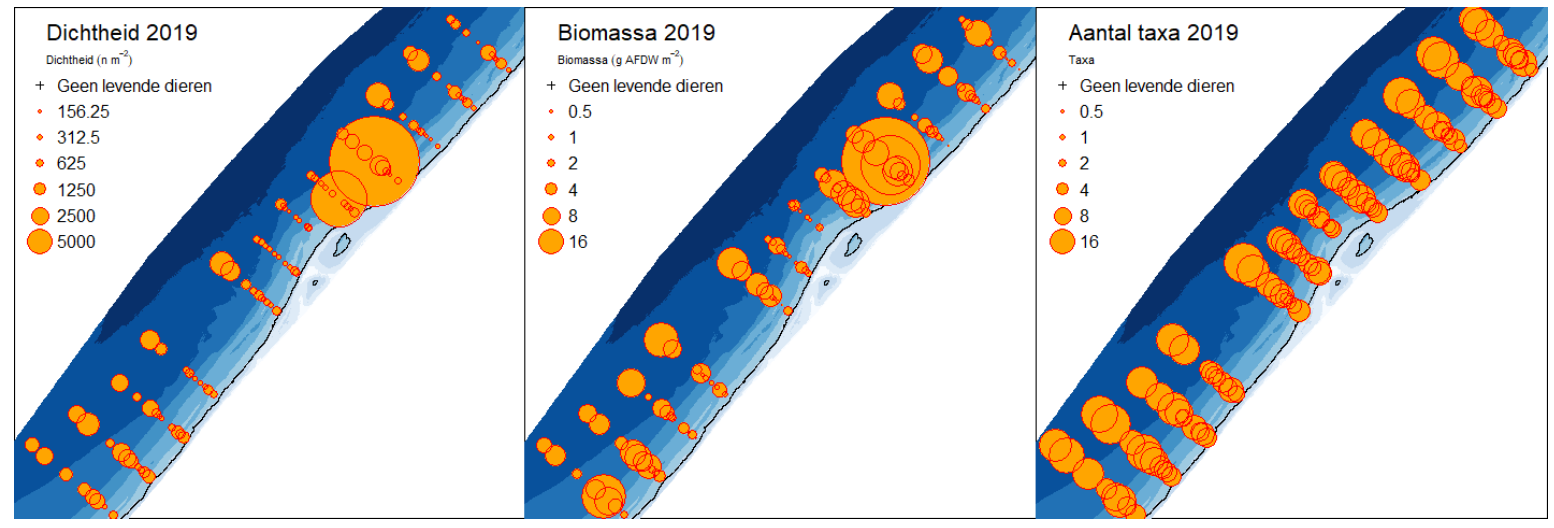

Figuur 49: Verspreidingskaart totale dichtheid (aantal $\mathrm{m}^{-2}$ ), bodemdierbiomassa $\left(\mathrm{g} \mathrm{AFDW} \mathrm{m}^{-2}\right.$ ) en het aantal taxa per monster in de Van Veen bemonstering 2019. De soorten Ensis spp., Mya arenaria en Lutraria lutraria zijn niet meegenomen in de biomassa.

In Figuur 50 zijn de dichtheden, biomassa's en het aantal taxa voor de Van Veen bemonstering in 2019 uitgezet voor de verschillende transecten. De transecten op de kop van de Zandmotor (5, 6, 7 en 8) zijn relatief laag in dichtheid en transecten 6 en 7 ook in biomassa, terwijl de transecten 0,1 en 9 een relatief hoge dichtheid en biomassa hebben. Ook het aantal taxa dat is aangetroffen, is relatief laag op de transecten op en net ten zuiden van de Zandmotor (transecten 3 tot en met 8). 

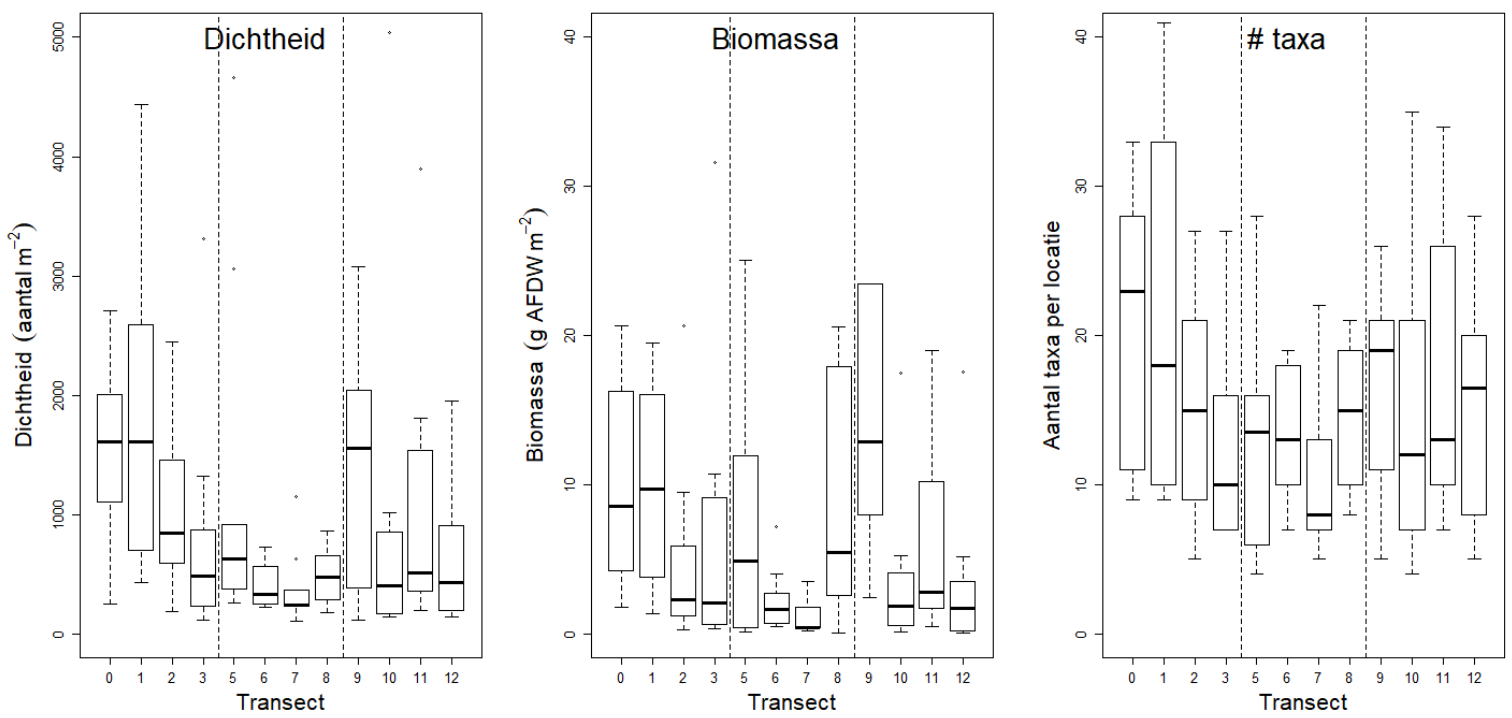

Figuur 50: Boxplots van dichtheid (aantal $\mathrm{m}^{-2}$ ), biomassa $\left(\mathrm{g} \mathrm{AFDW} \mathrm{m}^{-2}\right.$ ) en aantal soorten in 2019 over de verschillende transecten van het meest zuidelijke (transect 0 ) naar het meest noordelijke (transect 12). De verticale stippellijnen geven de scheiding tussen de verschillende deelgebieden. De soorten Ensis spp., Mya arenaria en Lutraria lutraria zijn niet meegenomen in de biomassa. Uitschieters (zie tekst) zijn in de figuur ziet zichtbaar.

In Figuur 51, Figuur 52 en Figuur 53 zijn respectievelijk de verspreiding van de totale dichtheid aan bodemdieren (aantal $\mathrm{m}^{-2}$ ), biomassa $\left(\mathrm{g} \mathrm{AFDW} \mathrm{m}^{-2}\right.$ ) en het aantal aangetroffen taxa in de Van Veen bemonstering uitgezet voor de verschillende jaren. Figuur 51 laat zien dat 2010 een relatief arm jaar is en 2012 juist een rijk jaar wat betreft de dichtheid aan bodemdieren. Over de tijd lijkt er een ruimtelijke ontwikkeling op te treden waarbij de dichtheden van bodemdieren op de transecten op en ten zuiden van de Zandmotor (transecten 3, 5, 6 en 7) afnemen na 2012. In vergelijking met de voorgaande jaren $(2013,2015$ en 2017) zijn de dichtheden aan bodemdieren die in de ondiepe zone zijn aangetroffen in 2019 relatief hoog, voornamelijk in de meest zuidelijke transecten ( 0 tot en met 3). In Figuur 53 is ook de toename in diversiteit, uitgedrukt in aantal soorten per locatie, met de diepte te zien. Ook is te zien dat de stations op de kop van de Zandmotor (transecten 6 en 7) relatief arm zijn qua aantal soorten dat er wordt aangetroffen.

In Bijlage 8 een aantal specifieke soorten. Zo is te zien dat het zaagje (Donax vittatus), dat in 2017 massaal is aangetroffen in 2010 helemaal niet is aangetroffen en in 2013 slechts op een 4-tal locaties (Figuur 80). Scolelepis (Scolelepis) squamata is een soort die voornamelijk in de dynamische ondiepe gebieden voorkomt (Figuur 85). Deze soort is ook een van de belangrijkste soorten (in voorkomen) op het strand. 


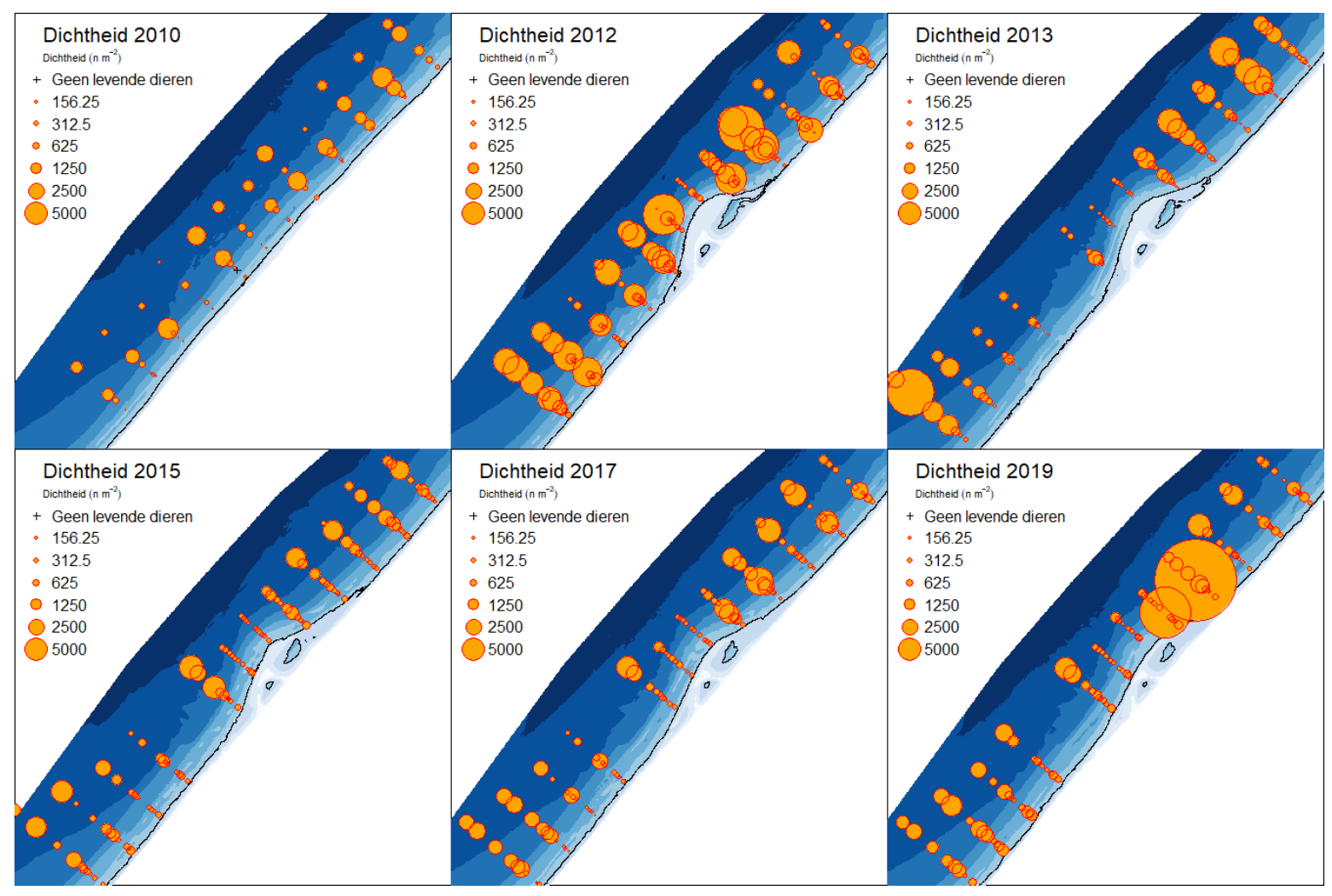

Figuur 51: Verspreidingskaart totale bodemdierdichtheid (aantal $\mathrm{m}^{-2}$ ) bemonsterd met de Van Veen happer in 2010, 2012, 2013, 2015, 2017 en 2019. 


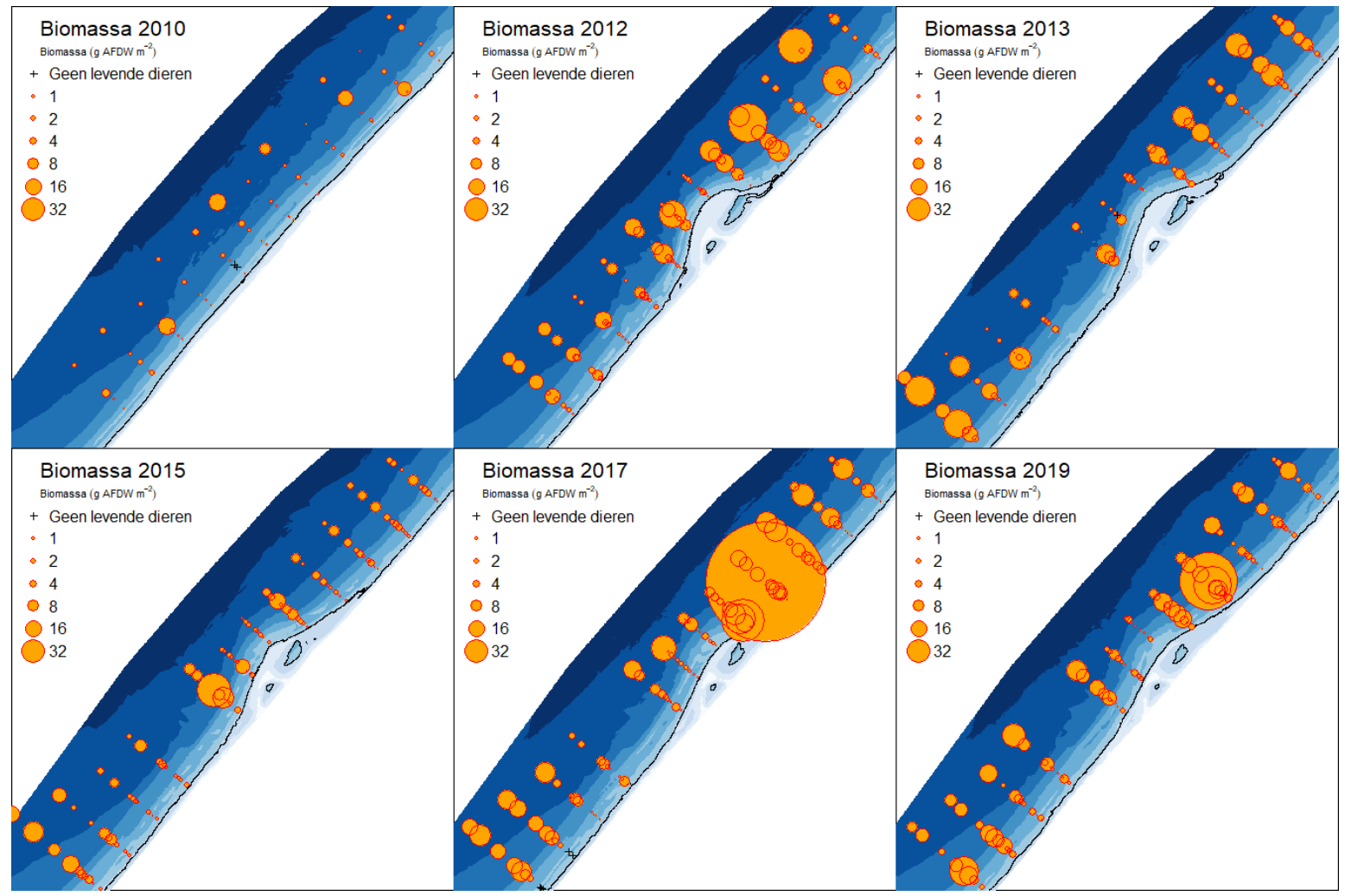

Figuur 52: Verspreidingskaart bodemdierbiomassa $\left(\mathrm{g} \mathrm{AFDW} \mathrm{m}^{-2}\right.$ ) bemonsterd met de Van Veen happer in 2010, 2012, 2013, 2015, 2017 en 2019.

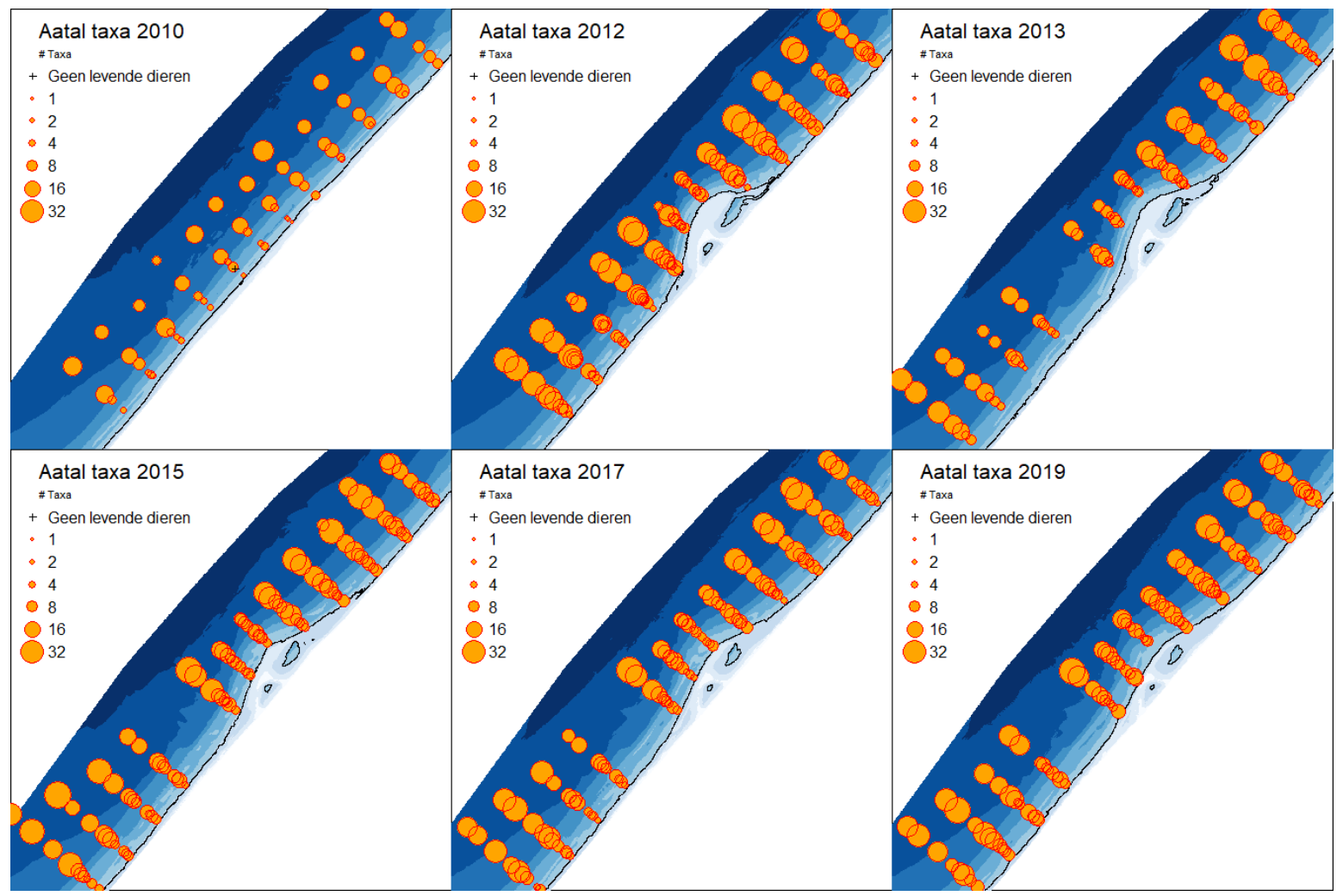

Figuur 53: Verspreidingskaart aantal taxa per monster bemonsterd met de Van Veen happer in 2010, 2012, 2013, 2015, 2017 en 2019. 


\subsubsection{Gemeenschapsanalyses}

De clusteranalyse op de vierdemachtswortel getransformeerde data (dichtheden) van 2019 resulteerde tot 16 significante clusters (Figuur 54), waarvan 6 clusters (a, b, f, g, i, j en I) bestonden uit slechts 1 locatie. Cluster $c$ is een groot cluster van 41 stations die voornamelijk in de geëxponeerde ondiepe stations liggen en op de kop van de Zandmotor. De bodemdiergemeenschap wordt gekenmerkt door de aanwezigheid van de Gemshorenworm (Scolelepis (Scolelepis) squamata) (Figuur 57) en Paraonis fulgens. Ruimtelijk vertoont cluster $\mathrm{c}$ overeenkomsten met clusters $\mathrm{m}$ en $\mathrm{n}$ uit de schaafbemonstering (Figuur 33). De 21 stations van cluster d liggen ook in de ondiepe zone, maar dan net iets dieper dan de stations van cluster $\mathrm{c}$ en op transect 8, aan de noordzijde van de Zandmotor. Dit cluster wordt gekenmerkt door soorten als Nephtys cirrosa en komen ook soorten als zaagje (Donax vittatus) voor die in cluster c vrijwel niet wordt aangetroffen. Ruimtelijk vertoont cluster d grote overeenkomsten met de verspreiding van cluster $h$ uit de schaafbemonstering (Figuur 33). De stations van clusters $\mathrm{k}$ en $\mathrm{n}$ bevinden zich op de middeldiepte tot diepe stations van de zuidelijke transecten (transect 0 tot en met 5) en worden gekenmerkt door soorten als de Noordelijke zandkokerworm (Spiophanes bombyx) en Rechtsgestreepte platschelp (Fabulina fabula). Op de nMDS plot (Figuur 56) liggen de stations van deze twee clusters bij elkaar in de buurt. De 15 stations van cluster $p$ liggen op de diepere delen van de drie noordelijkste transecten en in de diepe delen aan de kop van de Zandmotor. Dit cluster wordt gekenmerkt door soorten als Nephtys cirrosa en het nonnetje (Limecola balthica). Dit cluster vertoont ruimtelijke overeenkomsten met cluster d van de schaafbemonstering (Figuur 33). In de nMDS plot (Figuur 56) maar ook de ruimtelijke verspreiding van de clusters (Figuur 55 ) liggen de stations van cluster $k$ in de buurt van de stations van cluster $n$, voornamelijk in de diepere delen van transecten 0 tot en met 2.

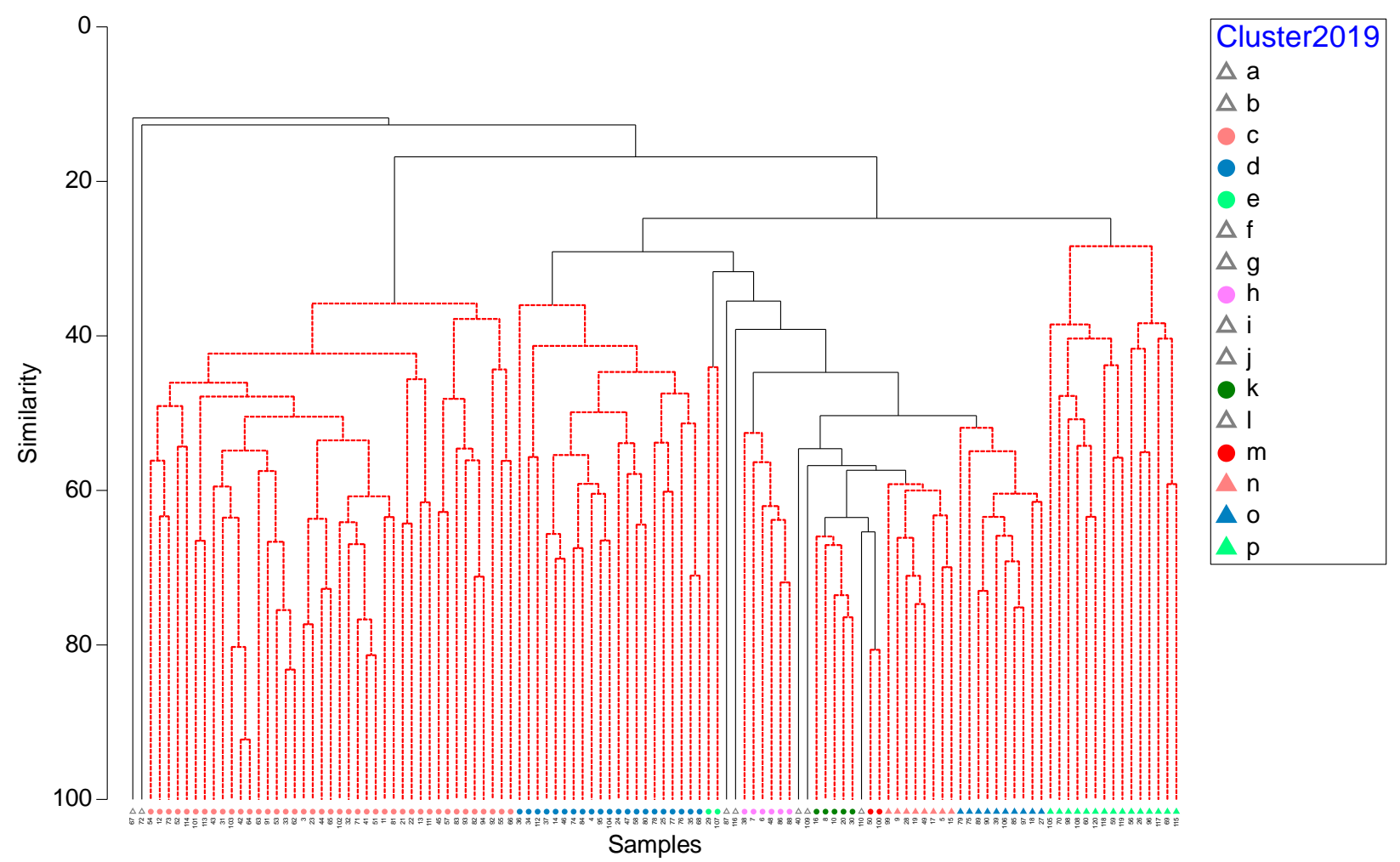

Figuur 54: Clusterdiagram van bodemdieren in de Van Veen bemonstering in 2019. De zwarte lijnen geven de significante clusters (Simprof test, $\mathrm{p}<0.05$ ). 


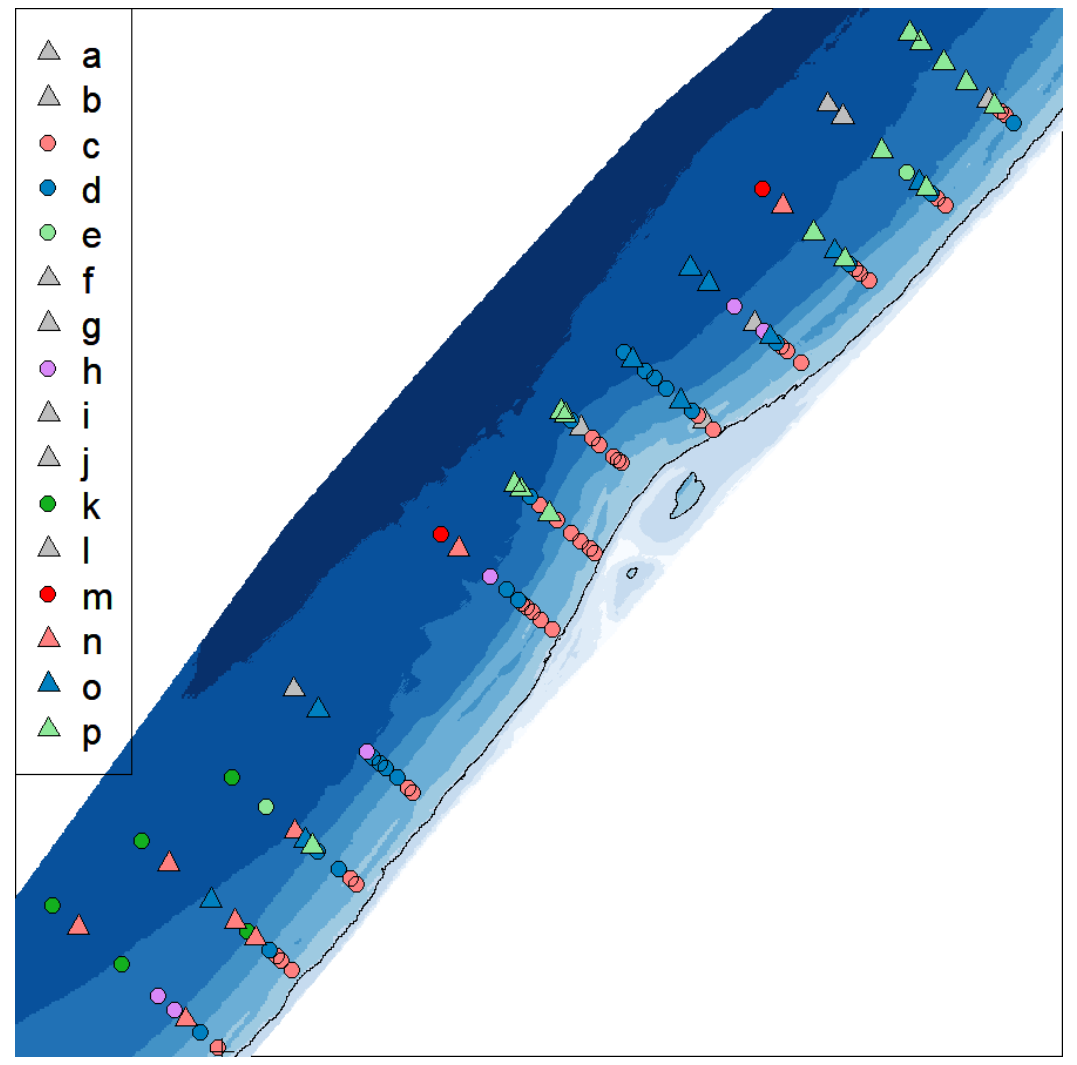

Figuur 55: Verspreidingskaart significante clusters bodemdiergemeenschappen Van Veen bemonstering 2019. De markers corresponderen met de markers uit de clusteranalyse (Figuur 54).

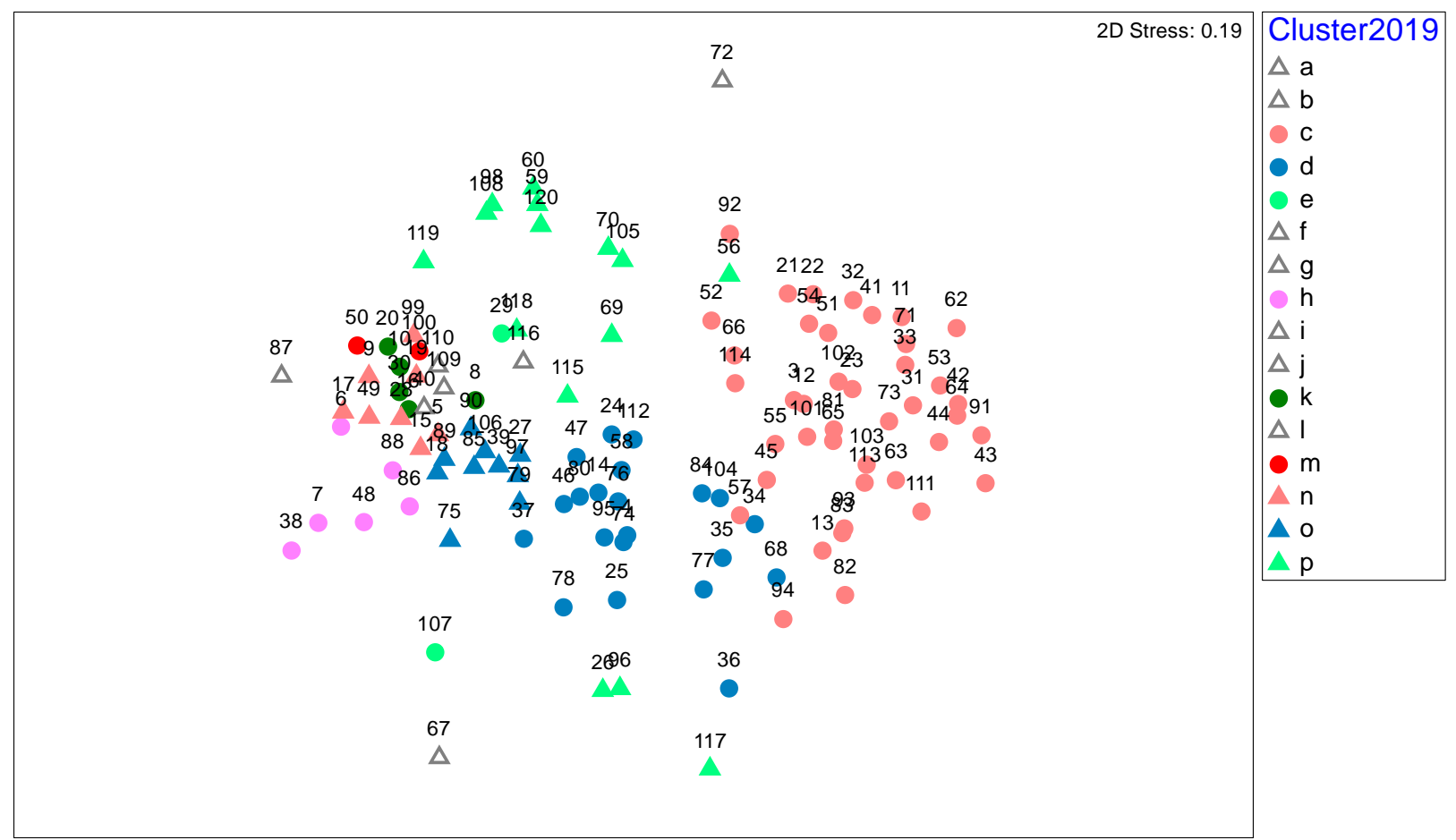

Figuur 56: nMDS plot Van Veen gegevens 2019. De labels geven de nummers van de bemonsteringslocaties weer. De kleur van de markers representeren de clusters uit de clusteranalyse. 


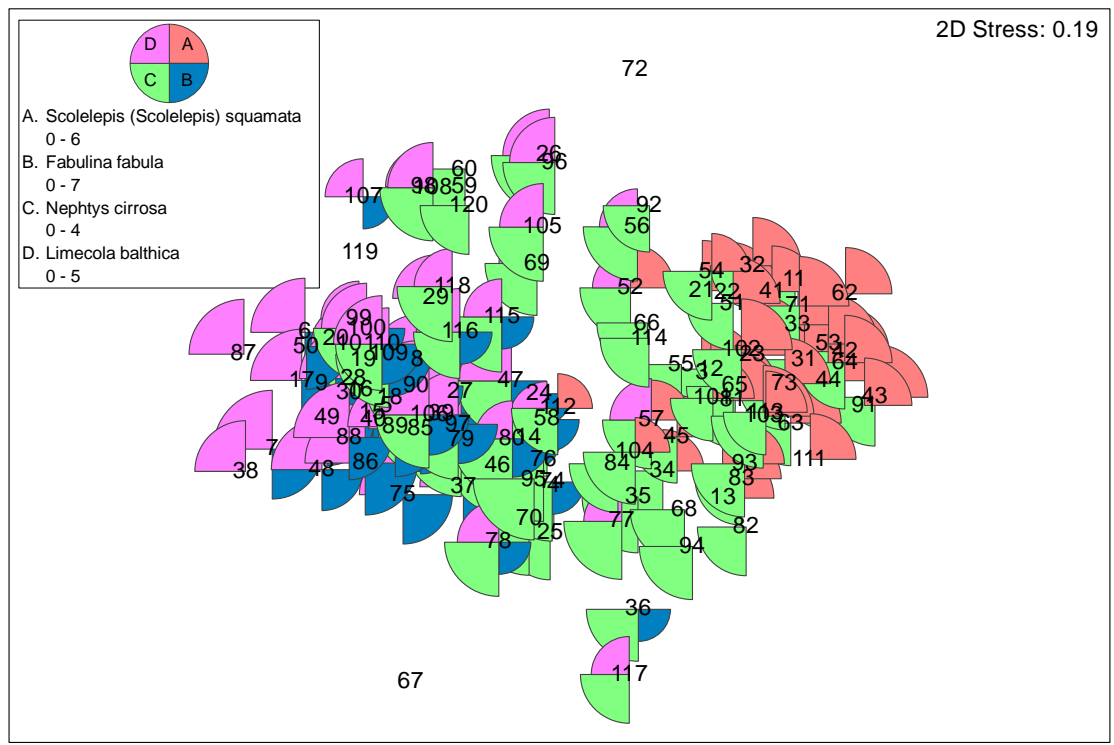

Figuur 57: nMDS plot Van Veen gegevens 2019, als in Figuur 56. De markers geven nu de relatieve dichtheid van een aantal karakteristieke soorten uit de clusteranalyse weer. De labels geven de nummers van de bemonsteringslocaties weer.

Om de ontwikkeling van de bodemdiergemeenschap in de tijd te visualiseren zijn er niet-metrische MDS plots gemaakt op de geaggregeerde data over alle jaren (2010 tot en met 2019). De dichtheden zijn hiervoor gemiddeld per jaar en gebied (Figuur 58) en per jaar en dieptestratum (Figuur 59). In de figuren is duidelijk te zien dat de bodemdiergemeenschap in alle drie de gebieden na de aanleg van de Zandmotor anders was dan voor de aanleg (2010). In 2013 is er een duidelijk verschil in bodemdiergemeenschap tussen de gebieden Zuid, Zandmotor en Noord, waarbij vooral het gebied Zandmotor afwijkt van de overige twee. In 2015 is het verschil tussen de gebieden minder, maar in 2017 en iets mindere mate in 2019 wijken ze weer van elkaar af. Op basis van deze figuur kan worden geconcludeerd dat de bodemdiergemeenschap zich aan het ontwikkelen is binnen het onderzoeksgebied en dat deze nog niet is teruggekeerd naar de situatie van voor de aanleg. Er is ook een verschil tussen de deelgebieden, maar de variatie als gevolg van de ontwikkeling over de tijd is groter. 


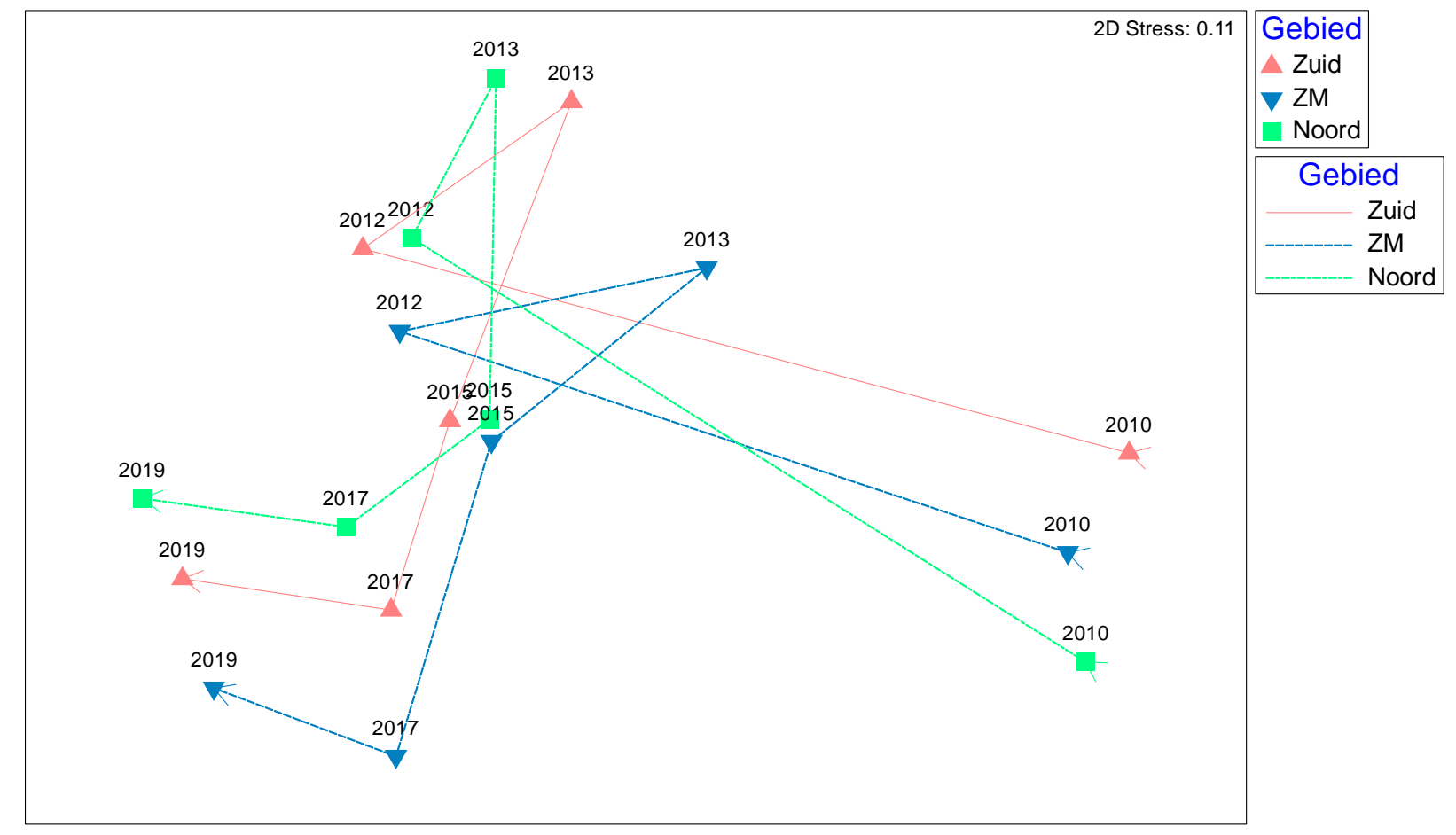

Figuur 58: nMDS plot van de ontwikkeling van de bodemdiergemeenschap (Van Veen gegevens) over de tijd voor de drie verschillende deelgebieden (Zuid, Zandmotor en Noord). De afstand tussen de punten is een mat voor de dissimilariteit in de bodemdiersamenstelling.

Ook in Figuur 59 is er een duidelijk effect van diepte te zien op de bodemdiergemeenschap over de horizontale as van de nMDS plot. De diepteklassen 1 tot en met 4 (tot een diepte van ongeveer -5 meter NAP, zie Tabel 1) onderscheiden zich duidelijk van de diepteklassen 5 tot en met 10 (vanaf -7 meter NAP). Dit is het meest duidelijk in de jaren 2010 en 2013. Ook is de ontwikkeling in de tijd te zien over de verticale as van nMDS plot van boven (2010) naar beneden (2019), al is deze minder duidelijk dan bij de data van de bodemschaaf (Figuur 38). De ontwikkeling is niet alleen beperkt tot de ondiepe gebieden, waar het effect van de Zandmotor op de morfologie het grootst is, maar is ook terug te vinden op de grotere dieptes. 


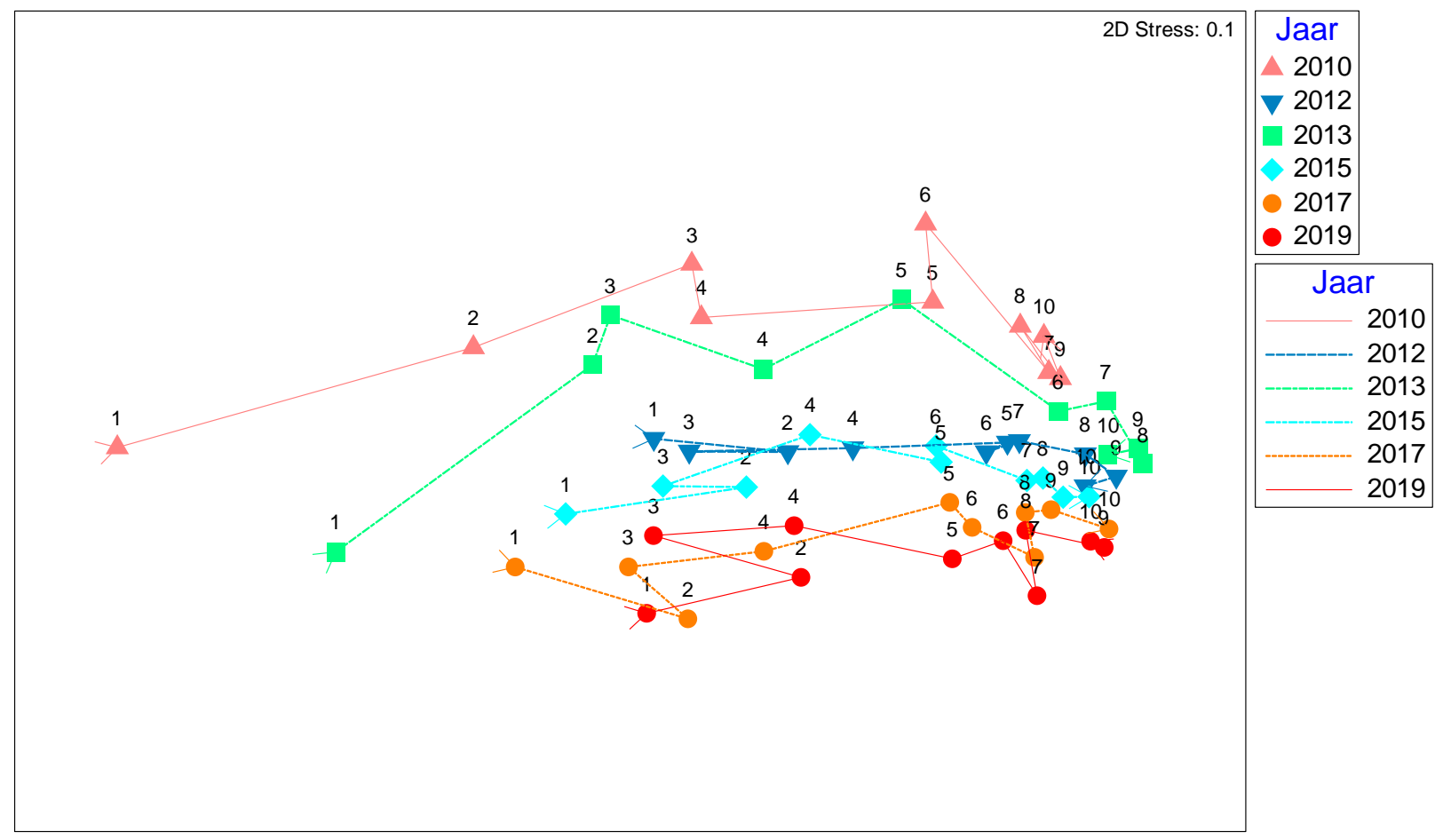

Figuur 59: nMDS plot van de ontwikkeling van de bodemdiergemeenschap (Van Veen gegevens) als functie van de diepte (diepteklasse, zie Tabel 1) over de verschillende jaren. De afstand tussen de punten is een maat voor de dissimilariteit in de bodemdiersamenstelling.

\subsection{Strandbemonstering}

\subsubsection{Overzicht}

In totaal zijn er in 201970 benthosmonsters genomen op het strand. Op 21 stations zijn geen levende bodemdieren aangetroffen. In totaal zijn er 21 taxa aangetroffen. Dit komt overeen met 2017 (20 taxa) maar is minder dan in de jaren 2013 en 2015 toen er nog zijn er nog respectievelijk 38 en 45 taxa in de strandmonsters aangetroffen. De gemiddelde dichtheid aan bodemdieren op het strand was in 2019119 individuen $\mathrm{m}^{-2}$ (st. dev. 248 individuen $\mathrm{m}^{-2}$ ) en de gemiddelde biomassa was $0.053 \mathrm{~g}$ AFDW m-2 (st. dev. $0.11 \mathrm{~g} \mathrm{AFDW} \mathrm{m}^{-2}$ ). Het gemiddeld aantal taxa per monster was in 20191.17 taxa (st. dev. 1.1 taxa). In Figuur 60 zijn de dichtheid, biomassa en aantal taxa in de strandmonsters over de verschillende jaren weergegeven. 

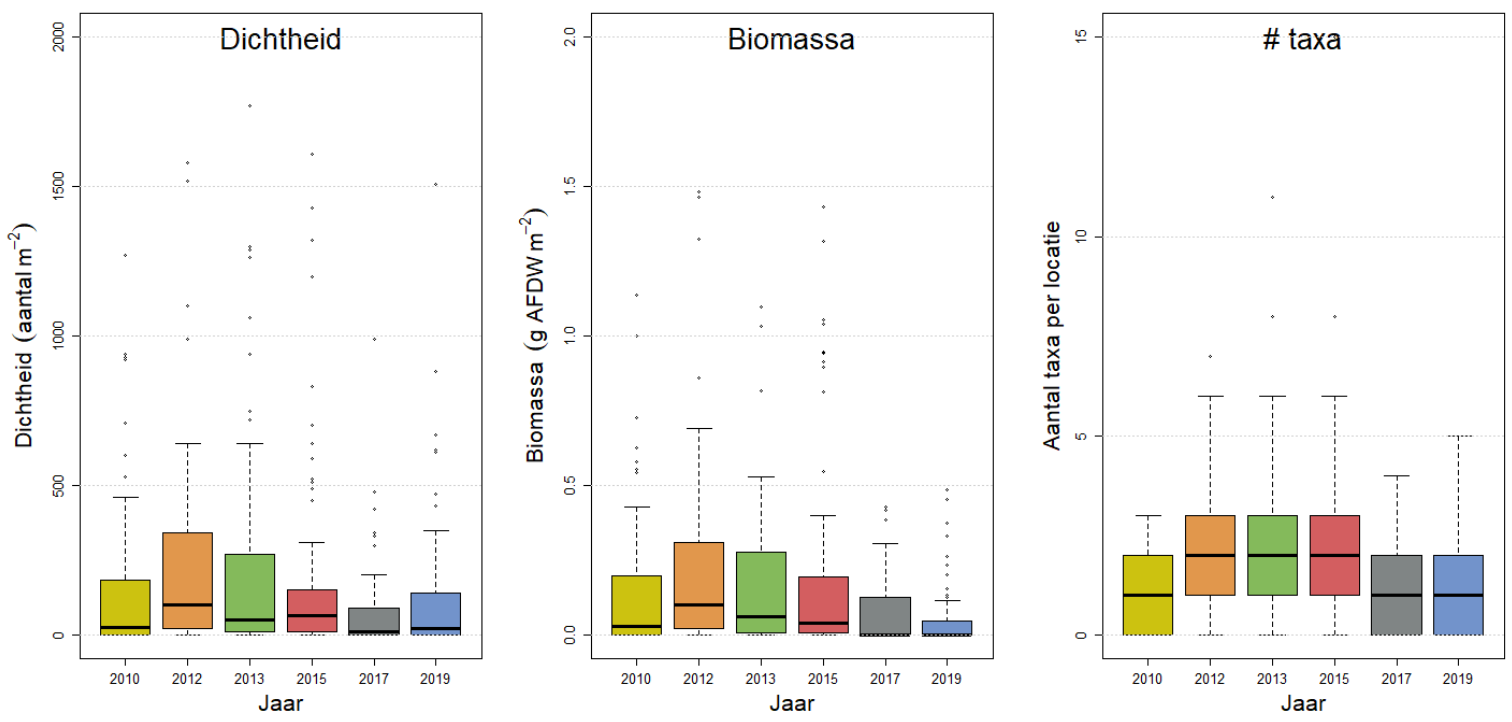

Figuur 60: Boxplots van dichtheid (aantal $\mathrm{m}^{-2}$ ), biomassa $\left(\mathrm{g} \mathrm{AFDW} \mathrm{m}^{-2}\right.$ ) en het aantal soorten per locatie voor de strandmonsters over de jaren 2010 tot en met 2019.

De meest voorkomende soorten in de strandmonsters zijn Scolelepis (Scolelepis) squamata, Haustorius arenarius, Eteone spp. en Pontocrates arenarius (Tabel 6). In 2019 was het relatieve voorkomen van deze soorten minder dan gemiddeld in andere jaren. De taxa Mytilus edulis, Nemertea indet. en Capitella spp. zijn in 2019 niet aangetroffen in de strandmonsters.

Tabel 6: $\quad$ Relatieve voorkomen (\% van de stations aangetroffen) van de 10 meest voorkomende taxa in de strandmonsters voor de jaren 2010, 2012, 2013, 2015, 2017 en 2019. In de laatste kolom het totaal over alle jaren.

\begin{tabular}{lcccccccc} 
Taxon & 2010 & 2012 & 2013 & 2015 & 2017 & 2019 & Totaal \\
Scolelepis (Scolelepis) squamata & 58.3 & 78.5 & 71.4 & 74.3 & 38.6 & 51.4 & 62 \\
\hline Haustorius arenarius & 31.7 & 36.9 & 32.9 & 42.9 & 17.1 & 14.3 & 29.1 \\
\hline Eteone spp. & 0 & 32.3 & 12.9 & 10 & 1.4 & 8.6 & 10.9 \\
\hline Pontocrates arenarius & 0 & 20 & 10 & 18.6 & 4.3 & 2.9 & 9.4 \\
\hline Eurydice pulchra & 6.7 & 10.8 & 4.3 & 4.3 & 10 & 2.9 & 6.4 \\
Mytilus edulis & 1.7 & 10.8 & 7.1 & 1.4 & 0 & 0 & 3.5 \\
Nemertea spp. & 0 & 4.6 & 7.1 & 8.6 & 0 & 0 & 3.5 \\
\hline Capitella spp. & 0 & 3.1 & 5.7 & 2.9 & 7.1 & 0 & 3.2 \\
Pygospio elegans & 0 & 4.6 & 4.3 & 5.7 & 1.4 & 1.4 & 3 \\
\hline Hydrozoa spp. & 0 & 0 & 7.1 & 0 & 1.4 & 5.7 & 2.5
\end{tabular}

Op basis van dichtheden zijn ook Scolelepis (Scolelepis) squamata en Haustorius arenarius de meest voorkomende soorten in de strandmonsters (Tabel 7). In 2019 kwamen de taxa Haustorius arenarius Capitella spp., Pontocrates arenarius, Nemertea spp., Pygospio elegans en Spiophanes bombyx in lagere dichtheden voor dan in de meeste andere jaren. zijn de dichtheden over het algemeen minder dan in voorgaande jaren, met uitzondering van de soorten Capitella spp., Eurydice pulchra en Heteromastus filiformis waarvan de dichtheden overeenkwamen met de gemiddelde dichtheid in voorgaande jaren en Polydora cornuta die alleen in 2013 in vergelijkbare dichtheden is aangetroffen. 
Tabel 7: $\quad$ Gemiddelde dichtheden van de meest dominante soorten (gemiddelde dichtheid in alle monsters $>1 \mathrm{~m}^{-2}$ ) die zijn verzameld op het strand over de jaren 2010, 2012, 2013, 2015, 2017 en 2019. In de laatste kolom het totaal over alle jaren.

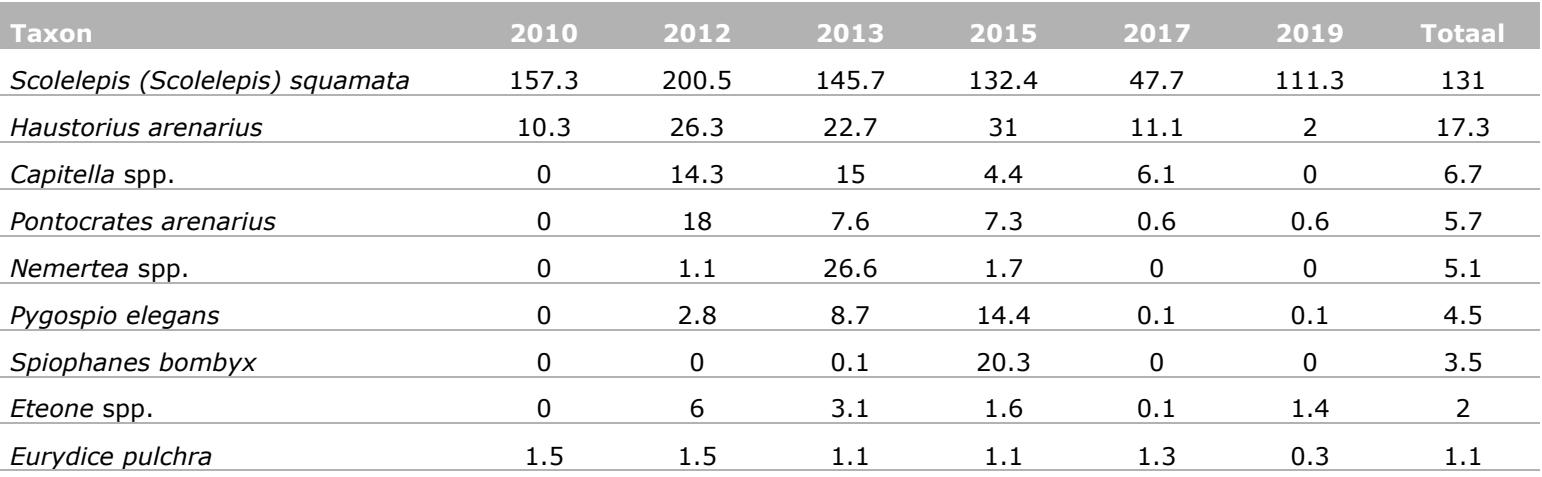

\subsubsection{Relatie met droogval}

Zowel de dichtheid, biomassa als het aantal aangetroffen taxa van de monsters op het strand heeft een relatie met de droogvalduur. In Figuur 61 zijn er 5 droogvalklassen gedefinieerd, overeenkomend met -5: monsterpunten op de hoogst gelegen delen van het strand (nabij de hoogwaterlijn) en -1 : monsterpunten die het kortste droogvallen (nabij de laagwaterlijn). De armste monsters zijn aangetroffen in droogvalklasse -5 en -4 , hoog in het intergetijdengebied. Deze locaties staan minder $20 \%$ van de tijd onder water. Op droogvalklassen -3 , -2 en -1 (meer dan $20 \%$ van de tijd onder water) is zowel de dichtheid als biomassa en het aantal aangetroffen taxa aanzienlijk hoger dan bij de hoogwaterlijn. Deze patronen komen overeen met de patronen die eerder zijn gevonden en kan worden toegeschreven aan de moeilijke omstandigheden hoog in het intergetijdengebied voor de mariene organismen (Van Egmond et al., 2018).
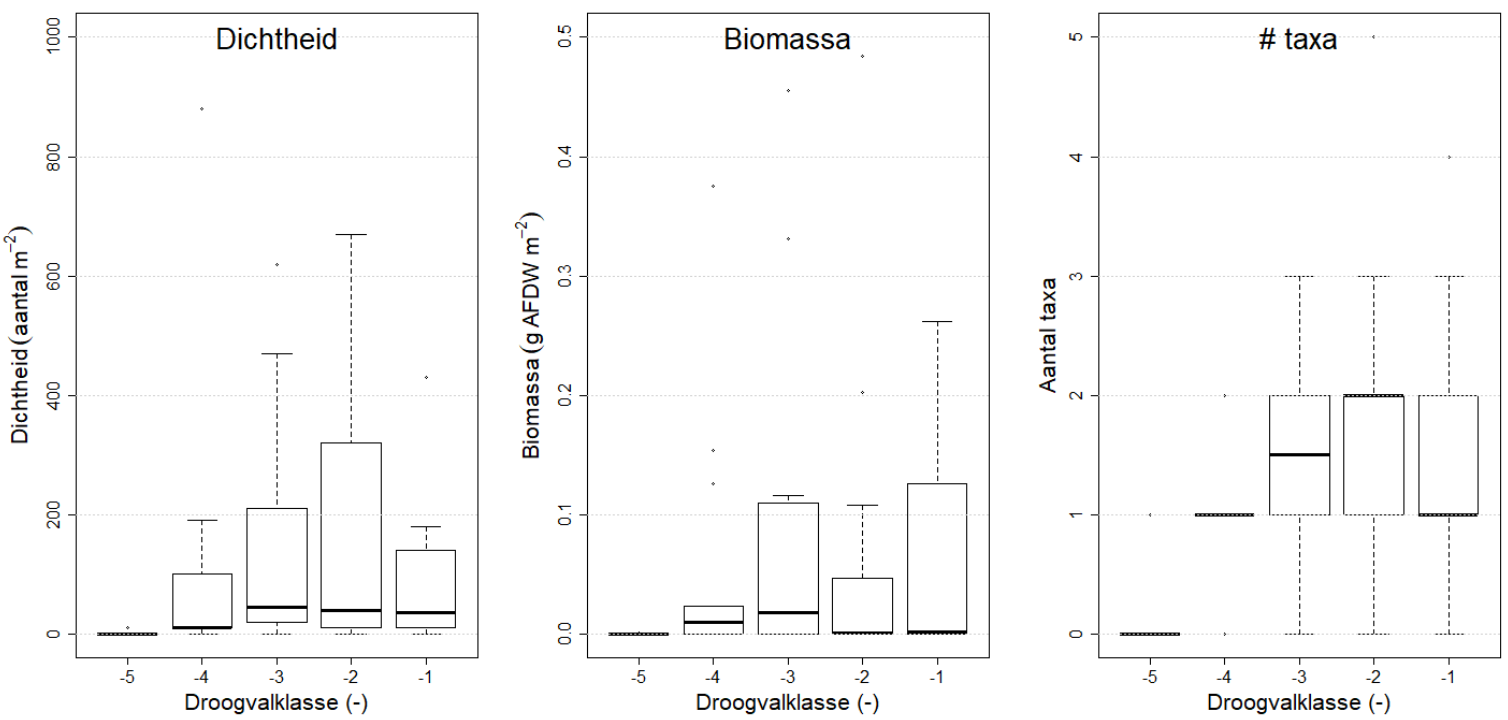

Figuur 61: Boxplots van dichtheid (aantal $\left.\mathrm{m}^{-2}\right)$, biomassa $\left(\mathrm{g} \mathrm{AFDW} \mathrm{m}^{-2}\right.$ ) en het aantal soorten per locatie voor de strandmonsters in 2019 als functie van de droogvalklasse. Klasse -5 is bij de hoogwaterlijn en klasse -1 is bij de laagwaterlijn. 


\subsubsection{Ruimtelijke verspreiding}

In 2019 zijn de hoogste totale dichtheden aan bodemdieren aangetroffen in de zuidelijkste transecten (transecten 0, 1, 2 en 3) en de transecten aan de zuidzijde van de Zandmotor (transecten 5 en 6) (Figuur 62). De transecten aan de noordzijde van de Zandmotor waren relatief arm. Aan de zuidzijde van de lagune waar in vorige jaren (2013, 2015 en 2017) redelijk wat bodendieren zijn aangetroffen, zijn in 2019 helemaal geen bodemdieren aangetroffen.

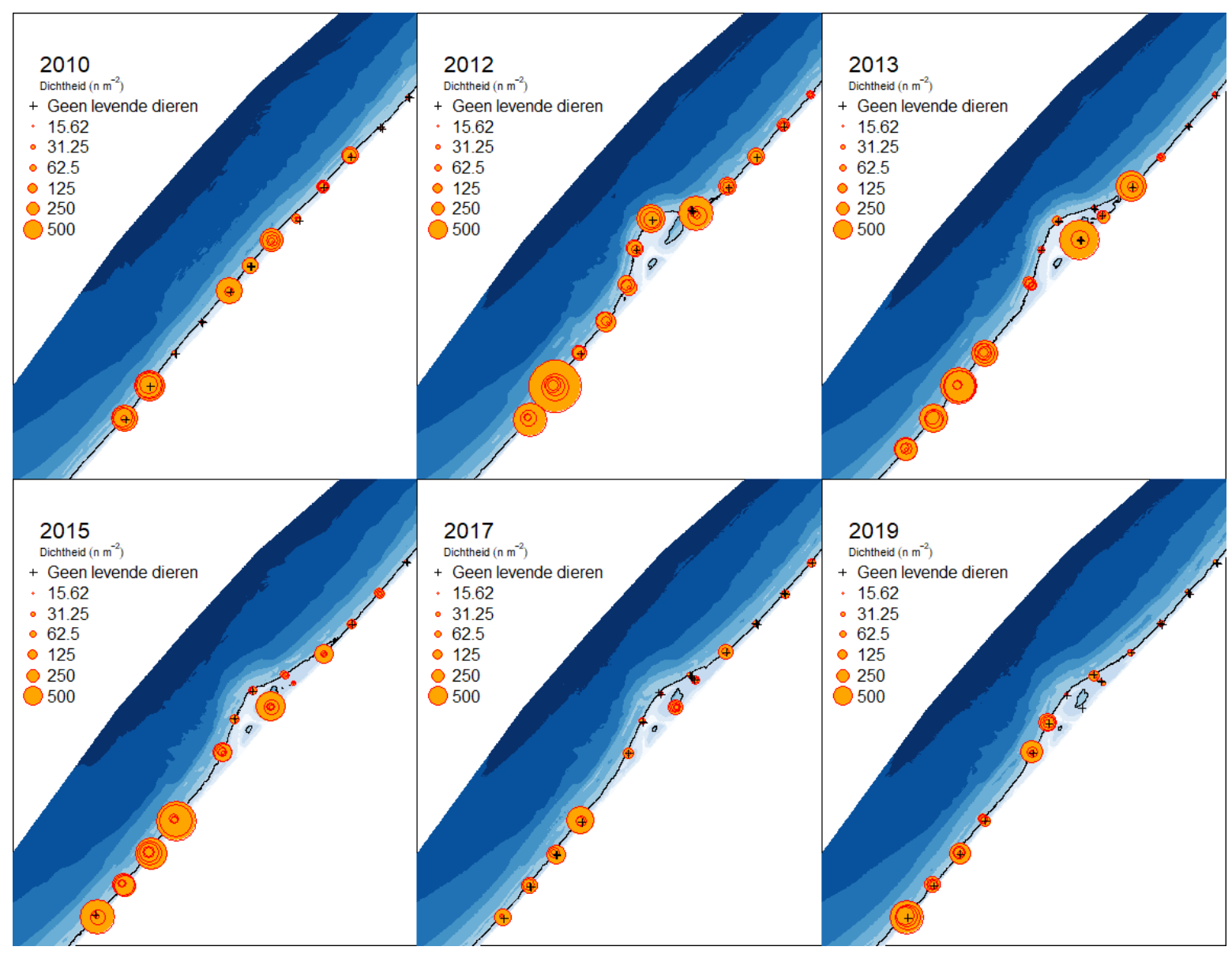

Figuur 62: Ruimtelijke verspreiding van dichtheid (aantal $\mathrm{m}^{-2}$ ) bodemdieren in de strandmonsters over de jaren 2010 tot en met 2019. 


\section{$4 \quad$ Conclusies en discussie}

Het doel van de bodemdierbemonstering binnen het project "monitoring en evaluatie pilot Zandmotor" is te onderzoeken wat het effect is van de aanleg van de Zandmotor op de ontwikkeling van de bodemdiergemeenschap. Een megasuppletie zoals de Zandmotor verschilt van reguliere strand- en vooroeversuppleties door zijn langere levensduur (ca 20 jaar in vergelijking tot de 3-5 jaar voor reguliere suppleties) en de schaal, waardoor een Zandmotor een groter effect heeft op de fysica en morfologie in het gebied op en rond de suppletie. Omdat de bodemdiergemeenschap in belangrijke mate afhankelijk is van de abiotiek (sedimentsamenstelling, getijstroming, golven) zal mogelijk ook de bodemdiergemeenschap zich aanpassen aan de verander(en)de situatie. Dit onderzoek richt zich op de temporele en ruimtelijke ontwikkeling van de bodemdiergemeenschap op en rond de Zandmotor om zo de invloed van de Zandmotor te onderzoeken.

In het najaar van 2019 is er door Wageningen Marine Research voor de $6^{\text {de }}$ keer, na de bemonsteringen van 2010, 2012, 2013, 2015 en 2017, een bodemdierbemonstering uitgevoerd op en rond de Zandmotor. In totaal zijn er in 2019113 stations bemonsterd in de vooroever met de bodemschaaf en 117 stations met de Van Veen happer. Tevens zijn er 70 stations bemonsterd op het strand tussen de hoog- en laagwaterlijn. Aanvullend zijn er 326 sedimentmonsters genomen, deels op de stations waar ook bodemdieren zijn bemonsterd (187 stations), en deels op tussenliggende transecten (139 stations).

Er is zijn duidelijke ruimtelijke patronen in de sedimentsamenstelling (mediane korrelgrootte) in het onderzoeksgebied op en rond de Zandmotor. Deels zijn deze patronen het directe gevolg van de Zandmotor. Zo is het sediment van de vooroever aan de kop van de Zandmotor relatief grof en zijn er gebieden met relatief fijn sediment ontstaan net ten noorden en ten zuiden van de Zandmotor. Het relatief grove zand aan de kop van de Zandmotor is waarschijnlijk het gevolg van de grote dynamiek (getijstroming en golven). Het fijnere materiaal net ten noorden en ten zuiden is mogelijk het gevolg van het bezinken van fijner materiaal in deze wat luwere zones (Huisman et al., 2016). Het ruimtelijk patroon dat is aangetroffen in 2019 komt in grote lijnen overeen met de ruimtelijke patronen die in voorgaande jaren (2013 tot en met 2017) zijn aangetroffen.

De gemiddelde biomassa aan de bodemdieren in de bodemschaaf in 2019 ( $75 \mathrm{~g} \mathrm{~m}^{-2}$, Ensis spp., otterschelpen en heremietkreeften niet meegenomen) was iets minder dan in $2017\left(84.5 \mathrm{~g} \mathrm{~m}^{-2}\right)$ maar aanzienlijk hoger dan in de 2010, 20122013 en 2015 (respectievelijk 1, 23, 14 en $24 \mathrm{gram} \mathrm{m}^{-2}$ ). De gemiddelde dichtheid aan bodemdieren in de bodemschaaf was 190 individuen $\mathrm{m}^{-2}$. De hoogste dichtheid aan bodemdieren was 11000 individuen $\mathrm{m}^{-2}$ op station 2019_087 (voornamelijk witte dunschaal en halfgeknotte strandschelp). Niet eerder was de gemiddelde dichtheid zo hoog. Het gemiddeld aantal taxa per monster ( 7.8 taxa per monster) is iets hoger dan in voorgaande jaren maar aanzienlijk hoger dan in 2010 toen er gemiddeld 2.7 taxa per monster is aangetroffen. In het najaar van 2019 zijn er relatief veel venusschelpen (Chamelea strialuta), rechtsgestreepte strandschelpen (Fabulina fabula) en halfgeknotte strandschelpen (Spisula subtruncata) in de monsters aangetroffen. Uit de WOT bestandopname in de kustzone (Perdon et al., 2019) blijkt dat 2019 een goed jaar was voor de halfgeknotte strandschelpen. Opvallende nieuwkomer in de bemonstering was de Amerikaanse strandschelp (Mulinia lateralis), een exoot die in 2017 voor het eerst aangetroffen in de Voordelta (Craeymeersch et al., 2019). Het totaal aantal soorten dat is geschat uit de bemonstering met de bodemschaaf is 36 , dit is meer dan in voorgaande jaren (27 tot 32 soorten).

Het aantal taxa dat is aangetroffen in de Van Veen bemonstering is mede vanwege de kleinere zeef die wordt gebruikt groter dan in de bodemschaaf. In totaal werden in 2019 er op basis van de Van Veen bemonstering 150 taxa geschat. Dit is iets lager dan in 2017 (186) maar komt overeen met de jaren 2012 tot 2015. In 2010 zijn er 100 taxa geschat op basis van de Van Veen bemonstering. In 2010 zijn slechts de helft van de monsters (60) uitgezocht. De gemiddelde totale dichtheid van bodemdieren in de Van Veen bemonstering was is 20191711 individuen $\mathrm{m}^{-2}$ en dit is de grootste 
gemiddelde dichtheid dit tot op heden is aangetroffen rond de Zandmotor. De gemiddelde biomassa in de Van Veen monsters in 2019 was $8.71 \mathrm{~g} \mathrm{AFDW} \mathrm{m}^{-2}$. Dit is zonder Ensis spp., Mya arenaria en Lutraria lutraria.

De dichtheid, biomassa en aantal soorten van de bodemdieren neemt toe met de waterdiepte. Vooral de ondiepe zone (tot en met -5 meter NAP) is arm en is gekenmerkt door specifieke soorten zoals de breedpootkrab (Portumnus latipes) en de gemshorenworm (Scolelepis (Scolelepis) squamata). Op grotere diepten (dieper dan -6 m NAP) neemt de dichtheid, biomassa en het aantal soorten per monster sterk toe, met de hoogste waarden op dieptes groter dan $11 \mathrm{~m}$.

De nMDS plots van zowel de bodemschaaf als van de Van Veen monsters laten, naast een dieptepatroon ook een sterk van jaar tot jaar effect zien. Na de aanleg in 2011 is de bodemdiergemeenschap sterk veranderd, zowel binnen het suppletiegebied als ten noorden en ten zuiden van de suppletie. Vanaf die tijd heeft het gebied zich verder ontwikkeld maar is niet teruggekeerd naar de situatie van voor de aanleg (2010). De Van Veen bemonstering laat wel een afwijking zien van de bodemdiergemeenschap in het suppletiegebied (transecten 5 tot en met 12) voor de jaren 2013, 2017 en 2019 ten opzichte van de gebieden noord en zuid van de suppletie. Dit is niet duidelijk te zien in de nMDS plot van de bodemschaaf.

De resultaten van de bodemschaaf en de Van Veen bemonstering zijn tot op zekere hoogte goed met elkaar te vergelijken. Dit terwijl beide methodieken een ander type bodemdieren wordt bemonsterd. De bodemschaaf heeft een grotere maaswijdte $(5 \mathrm{~mm})$ zodat wormen en kleinere kreeftachtigen niet worden meegenomen. De bodemschaaf is dan ook vooral een geschikt monstertuig voor schelpdieren. Omdat deze schelpdieren een belangrijke bron zijn voor vogels, zijn in dit rapport dan ook voornamelijk verspreidingskaartjes van de biomassa uit de bodemschaaf opgenomen. Met de Van Veen happer worden juist de zeldzame grotere en mobiele dieren minder goed bemonsterd (Ens et al., 2007). Met de bodemschaaf wordt een groter bodemoppervlak bemonsterd dan met de Van Veen happer en is daarom minder gevoelig voor toevalligheden. De Van Veen happer is een geschikter monstertuig om iets te kunnen zeggen over de biodiversiteit. De verspreidingskaartjes van bodemdieren uit de Van Veen happer in dit rapport zijn daarom voornamelijk gebaseerd op de dichtheden.

De bodemdiergemeenschap van het strand, tussen de hoog- en laagwaterlijn, is aanzienlijk armer (vooral hoog in het intergetijdengebied) dan de bodemgemeenschap in de vooroever en wordt voornamelijk gekenmerkt door Scolelepis (Scolelepis) squamata. Vooral de soortensamenstelling op het relatief beschutte strand langs de lagune wijkt af van de overige stations op het strand.

De aanleg van de Zandmotor heeft geleid tot meer diversiteit in abiotiek (bodemschuifspanning door getij en golven, sedimentsamenstelling, sedimentatie/erosie) in het onderzoeksgebied. De bodemdiergemeenschap lijkt zich hierop te hebben aangepast. Om het effect van de Zandmotor op de bodemdiergemeenschap goed te kunnen begrijpen, is het van belang de relatie met de abiotiek te analyseren en te begrijpen. Het zou daarom interessant zijn om de ruimtelijke en temporele patronen in de bodemdiergemeenschap te vergelijken met abiotische parameters die worden beïnvloed door de Zandmotor zoals sedimentsamenstelling, golfenergie getijdenstroming en sedimentatie/erosie. Om dit te kunnen doen zullen resultaten van modelberekeningen (bodemschuifspanning golven en stroming), bathymetrieopnames (sedimentatie/erosie) en sedimentsamenstelling moeten worden vergleken met de resultaten van de bodemdierbemonstering. Deze kennis kan nuttig zijn in het ontwerp van toekomstige mega-suppleties zoals de Zandmotor.

De bemonstering van de bodemdiergemeenschap ik 2019 was voorlopig de laatste bemonstering van bodemdieren bij de Zandmotor. Uit de gegevens blijkt dat de bodemdiergemeenschap zich niet heeft hersteld naar de situatie van voor de aanleg. Deels komt dit door de aanwezigheid van de Zandmotor en deels komt dit door autonome ontwikkelingen in het gebied. Het herstel van de bodemdiergemeenschap kan nog jaren duren, aangezien de verwachting is dat de Zandmotor pas 20 jaar na aanleg zal zijn verdwenen. Tot die tijd zal de Zandmotor de hydro- en morfodynamiek in het gebied en daarmee de bodemdiersamenstelling blijven beïnvloeden. 


\section{$5 \quad$ Kwaliteitsborging}

Wageningen Marine Research beschikt over een ISO 9001:2015 gecertificeerd kwaliteitsmanagementsysteem. Dit certificaat is geldig tot 15 december 2021. De organisatie is gecertificeerd sinds 27 februari 2001. De certificering is uitgevoerd door DNV GL. 


\section{Literatuur}

Baptist, M., J. E. Tamis, B. W. Borsje en J. J. Van der Werf (2009) Review of the geomorphological, benthic ecological and biogeomorphological effects of nourishments on the shoreface and surf zone of the Dutch coast. Wageningen IMARES / Deltares, Rapport nummer: Report IMARES C113/08, Deltares Z4582.50.

Birklund, J. en J. W. M. Wijsman (2005) Ecological effects of aggregate extraction, Pages J1-J11 in L. C. Van Rijn, R. L. Soulsby, P. Hoekstra, en A. G. Davies, eds. Sandpit. Sand transport and morphology of offshore sand mining pits. Process knowledge and guidelines for coastal management. Amersfoort, Aqua Publications.

Boon, A. R. en J. W. M. Wijsman (2012) Monitoring en Evaluatie Pilot Zandmotor Fase 2 - Meetrapportage monstername najaar 2011 van benthos, vis vooroever, lagune en strand. Deltares / IMARES, Rapport nummer: C049/12, 28 pagina's.

Clarke, K. R., R. N. Gorley, P. J. Somerfield en R. M. Warwick (2014a) Change in marine communities: An approach to statistical analysis and interpretation. 3rd Edition. Plymouth, PRIMER-E Ltd.

Clarke, K. R., J. R. Tweedley en F. J. Valesini (2014b) Simple shade plots aid better long-term choices of data pre-treatment in multivariate assemblage studies. Journal of the Marine Biological Association of the United Kingdom 94: 1-16.

Clarke, K. R. en R. N. Gorley (2015) PRIMER v7: User manual/Tutorial. Plymouth, PRIMER-E Ltd.

Craeymeersch, J. A., M. A. Faasse, H. Gheeradryn, K. Troost, R. Nijland, A. Engelberts, K. J. Perdon, D. Van den Ende en J. Van Zwol (2019) First records of the dwarf surf clam Mulinia lateralis (Say, 1822) in Europe. Marine Biodiversity Records 12: 11.

Ebbens, E. en J. Fiselier (2010) Monitoring- en evaluatieplan Zandmotor. DHV, Rapport, 38 pagina's.

Ens, B. J., J. A. Craeymeersch, F. E. Fey, H. J. L. Heessen, A. C. Smaal, A. G. Brinkman, R. Dekker, J. R. Van Der Meer en M. Van Stralen (2007) Sublitorale natuurwaarden in de Waddenzee. Een overzicht van bestaande kennis en een beschrijving van de onderzoeksopzet voor een studie naar het effect van mosselzaadvisserij en mosselkweek op sublitorale natuurwaarden. Wageningen IMARES, Rapport nummer: C077/07, 117 pagina's.

Fiselier, J. (2010) Projectnota/ MER. Aanleg en zandwinning Zandmotor Delflandse kust. DHV, Rapport nummer: C6158-01.001, 303 pagina's.

Goldsmit, J., K. L. Howland en P. Archambault (2014) Establishing a baseline for early detection of nonindigenous species in ports of the Canadian Arctic. Aquatic Invasions 9: 327-342.

Huisman, B. J. A., M. A. De Schipper en B. G. Ruessink (2016) Sediment sorting at the Sand Motor at storm and annual time scales. Marine Geology 381: 209-226.

Perdon, J., K. Troost, J. Van Zwol, M. Van Asch en J. Van der Pool (2019) Schelpdierbestanden in de Nederlandse kustzone in 2019. Wageningen Marine Research, Rapport nummer: 19.010, 50 pagina's.

Taal, M., B. Arens, K. Kuijper, P. K. Tonnon, B. Van Der Valk, C. T. M. Vertegaal en J. W. M. Wijsman (2017) Uitvoeringsprogramma Monitoring en Evaluatie Pilot Zandmotor. Fase 3: periode 2017 t/m 2021. Deltares, Rapport nummer: 11200028-000-ZKS-0003, 68 pagina's.

Taal, M. D., M. A. M. Löffler, C. T. M. Vertegaal, J. W. M. Wijsman, B. Van Der Valk en P. K. Tonnon (2016a) Ontwikkeling van de Zandmotor. Samenvattende rapportage over de eerste vier jaar van het Monitoringen Evaluatie Programma (MEP). Deltares, Rapport, 61 pagina's.

Taal, M. D., M. A. M. Löffler, C. T. M. Vertegaal, J. W. M. Wijsman, B. Van Der Valk en P. K. Tonnon (2016b) Development of the Sand Motor Concise report describing the first four years of the Monitoring and Evaluation Programme (MEP). Deltares, Rapport, 61 pagina's.

Tonnon, P. K. en M. J. Baptist (2011) To-rapportage Monitoring en Evaluatie Pilot Zandmotor. Deltares/IMARES, Rapport nummer: Deltares 1203519-000 / IMARES C016/11, 198 pagina's.

Tonnon, P. K., L. Van der Valk, H. Holzhauer, M. J. Baptist, J. W. M. Wijsman, C. T. M. Vertegaal en S. M. Arens (2011) Uitvoeringsprogramma Monitoring en Evaluatie pilot Zandmotor. Deltares/Wageningen IMARES, Rapport nummer: C172/10, 154 pagina's.

Van der Wal, J. T. en J. A. Van Dalfsen (2008) Monitoring kustsuppleties. Wageningen IMARES, Rapport, 114 pagina's.

Van Egmond, E., M., P. M. Van Bodegom, M. P. Berg, J. W. M. Wijsman, L. Leewis, G. M. Janssen en R. Aerts (2018) A mega-nourishment creates novel habitat for intertidal macrointervebrates by enhancing habitat relief on the sandy beach. Estuarine Coastal And Shelf Science 207: 232-241.

Wentworth, C. K. (1922) A scale of grade and class terms for clastic sediments. Journal of Geology 30: 377392. 
Wijsman, J. W. M. en E. Verduin (2011) To monitoring Zandmotor Delflandse kust: Benthos ondiepe kustzone en natte strand. Wageningen IMARES, Rapport nummer: C039/11, 75 pagina's.

Wijsman, J. W. M. (2014a) Monitoring en Evaluatie Pilot zandmotor Fase 2: Datarapport benthos bemonstering vooroever en natte strand najaar 2012. Deltares / IMARES, Rapport nummer: C149/14, 49 pagina's.

Wijsman, J. W. M. (2014b) Monitoring en Evaluatie Pilot zandmotor Fase 2: Datarapport benthos bemonstering vooroever en natte strand najaar 2013. Deltares / IMARES, Rapport nummer: C150/14, 57 pagina's.

Wijsman, J. W. M., P. C. Goudswaard, V. Escaravage en S. Wijnhoven (2014) De macrobenthosgemeenschap van de Zeeuwse Banken na zandwinning. Een overzicht van drie $T_{0}$ jaren en een eerste jaar van rekolonisatie. IMARES, Rapport nummer: C164/13, 95 pagina's.

Wijsman, J. W. M. (2016) Monitoring en Evaluatie Pilot Zandmotor Fase 2 Datarapport benthos bemonstering vooroever en strand najaar 2015. IMARES, Rapport nummer: C006/16, 67 pagina's.

Wijsman, J. W. M., D. Ende en E. Brummelhuis (2018) Bodemdiergemeenschap in de vooroever en op het natte strand van de zandmotor in het najaar 2017. Datarapport. Wageningen Marine Research, Rapport nummer: C073/18, 99 pagina's. 


\section{Verantwoording}

Rapport C084/20

Projectnummer: 4313100069

Dit rapport is met grote zorgvuldigheid tot stand gekomen. De wetenschappelijke kwaliteit is intern getoetst door een collega-onderzoeker en het verantwoordelijk lid van het managementteam van Wageningen Marine Research

Akkoord

Handtekening:

Datum:

Akkoord:

Handtekening:

Datum:
Dr. J.A. Craeymeersch

Senior onderzoeker

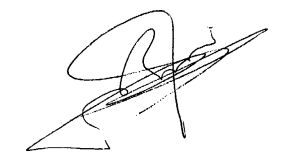

5 oktober 2020

Dr. T. Bult

Directeur Wageningen Marine Research

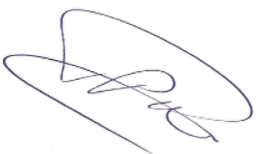

5 oktober 2020 


\section{Bijlage 1 Bemonsteringslocaties bodemschaaf}

\begin{tabular}{|c|c|c|c|c|c|}
\hline \multirow{2}{*}{$\begin{array}{l}\text { Tabel 8: } \\
\text { StationNr }\end{array}$} & \multicolumn{5}{|c|}{$\begin{array}{l}\text { Bemonsteringslocaties met de bodemschaaf in 2019. De cöordinaten van d } \\
\text { locaties zijn gegeven in decimale graden (WGS84). Tijdens de bemonsterin } \\
\text { schaaf over deze locatie te trekken. De diepte van de locatie is gebaseerd } \\
\text { augustus } 2019 .\end{array}$} \\
\hline & Datum & $\begin{array}{l}\text { Latitude } \\
\text { (WGS84) }\end{array}$ & $\begin{array}{l}\text { Longitude } \\
\text { (WGS84) }\end{array}$ & Transect & $\begin{array}{c}\text { Diepte } \\
\text { (cm NAP) }\end{array}$ \\
\hline 2019_002 & 23/9/2019 & 52.00828 & 4.130814 & 0 & -333 \\
\hline 2019_003 & $16 / 9 / 2019$ & 52.00852 & 4.130333 & 0 & -223 \\
\hline 2019_004 & $16 / 9 / 2019$ & 52.00983 & 4.1278 & 0 & -508 \\
\hline 2019_005 & $16 / 9 / 2019$ & 52.01087 & 4.125785 & 0 & -708 \\
\hline 2019_006 & $16 / 9 / 2019$ & 52.01158 & 4.12435 & 0 & -799 \\
\hline 2019_007 & $16 / 9 / 2019$ & 52.01283 & 4.121933 & 0 & -901 \\
\hline 2019_008 & $16 / 9 / 2019$ & 52.01537 & 4.116938 & 0 & -998 \\
\hline 2019_009 & $16 / 9 / 2019$ & 52.01845 & 4.11092 & 0 & -1105 \\
\hline 2019_010 & $16 / 9 / 2019$ & 52.02025 & 4.107396 & 0 & -1151 \\
\hline 2019_011 & $23 / 9 / 2019$ & 52.01518 & 4.140142 & 1 & -165 \\
\hline 2019_012 & $16 / 9 / 2019$ & 52.01596 & 4.138641 & 1 & -480 \\
\hline 2019_013 & $23 / 9 / 2019$ & 52.01628 & 4.138001 & 1 & -319 \\
\hline 2019_014 & $23 / 9 / 2019$ & 52.01678 & 4.137035 & 1 & -491 \\
\hline 2019_015 & $18 / 9 / 2019$ & 52.01778 & 4.135088 & 1 & -696 \\
\hline 2019_016 & $18 / 9 / 2019$ & 52.01832 & 4.134006 & 1 & -809 \\
\hline 2019_017 & $18 / 9 / 2019$ & 52.0192 & 4.132299 & 1 & -907 \\
\hline 2019_018 & $18 / 9 / 2019$ & 52.0209 & 4.128922 & 1 & -1000 \\
\hline 2019_019 & $18 / 9 / 2019$ & 52.02389 & 4.123075 & 1 & -1101 \\
\hline 2019_020 & $16 / 9 / 2019$ & 52.02575 & 4.119466 & 1 & -1151 \\
\hline 2019_022 & $23 / 9 / 2019$ & 52.02244 & 4.148829 & 2 & -401 \\
\hline 2019_023 & $16 / 9 / 2019$ & 52.02289 & 4.147899 & 2 & -278 \\
\hline 2019_024 & $18 / 9 / 2019$ & 52.02369 & 4.146367 & 2 & -504 \\
\hline 2019_025 & $18 / 9 / 2019$ & 52.02518 & 4.143413 & 2 & -708 \\
\hline 2019_026 & $18 / 9 / 2019$ & 52.02561 & 4.142582 & 2 & -796 \\
\hline 2019_027 & $18 / 9 / 2019$ & 52.02609 & 4.141643 & 2 & -901 \\
\hline 2019_028 & $18 / 9 / 2019$ & 52.02681 & 4.140237 & 2 & -998 \\
\hline 2019_029 & $18 / 9 / 2019$ & 52.0288 & 4.136324 & 2 & -1100 \\
\hline 2019_030 & $16 / 9 / 2019$ & 52.03126 & 4.131514 & 2 & -1151 \\
\hline 2019_032 & $16 / 9 / 2019$ & 52.03027 & 4.156301 & 3 & -436 \\
\hline 2019_033 & $23 / 9 / 2019$ & 52.03065 & 4.155572 & 3 & -290 \\
\hline 2019_034 & $18 / 9 / 2019$ & 52.03144 & 4.154029 & 3 & -500 \\
\hline 2019_035 & $18 / 9 / 2019$ & 52.03225 & 4.152423 & 3 & -702 \\
\hline 2019_036 & $18 / 9 / 2019$ & 52.03265 & 4.15164 & 3 & -802 \\
\hline 2019_037 & $18 / 9 / 2019$ & 52.03311 & 4.150768 & 3 & -897 \\
\hline 2019_038 & $18 / 9 / 2019$ & 52.03356 & 4.149884 & 3 & -999 \\
\hline 2019_039 & $18 / 9 / 2019$ & 52.03704 & 4.14307 & 3 & -1102 \\
\hline 2019_040 & $16 / 9 / 2019$ & 52.03875 & 4.139717 & 3 & -1153 \\
\hline 2019_041 & $23 / 9 / 2019$ & 52.04414 & 4.174872 & 5 & -128 \\
\hline 2019_042 & $23 / 9 / 2019$ & 52.04494 & 4.173298 & 5 & -399 \\
\hline 2019_043 & $23 / 9 / 2019$ & 52.04558 & 4.172039 & 5 & -321 \\
\hline 2019_044 & $23 / 9 / 2019$ & 52.04599 & 4.17124 & 5 & -505 \\
\hline 2019_045 & $17 / 9 / 2019$ & 52.0463 & 4.17064 & 5 & -683 \\
\hline
\end{tabular}




\begin{tabular}{|c|c|c|c|c|c|}
\hline StationNr & Datum & $\begin{array}{l}\text { Latitude } \\
\text { (WGS84) }\end{array}$ & $\begin{array}{l}\text { Longitude } \\
\text { (WGS84) }\end{array}$ & Transect & $\begin{array}{c}\text { Diepte } \\
\text { (cm NAP) }\end{array}$ \\
\hline 2019_046 & $17 / 9 / 2019$ & 52.04655 & 4.170126 & 5 & -788 \\
\hline 2019_047 & $17 / 9 / 2019$ & 52.0474 & 4.168486 & 5 & -900 \\
\hline 2019_048 & $17 / 9 / 2019$ & 52.04852 & 4.1663 & 5 & -1000 \\
\hline 2019_049 & $17 / 9 / 2019$ & 52.05079 & 4.16185 & 5 & -1090 \\
\hline 2019_050 & $17 / 9 / 2019$ & 52.052 & 4.159444 & 5 & -1143 \\
\hline 2019_051 & $23 / 9 / 2019$ & 52.05059 & 4.18051 & 6 & -125 \\
\hline 2019_052 & $23 / 9 / 2019$ & 52.05097 & 4.17976 & 6 & -424 \\
\hline 2019_053 & $24 / 9 / 2019$ & 52.05159 & 4.178558 & 6 & -245 \\
\hline 2019_054 & $24 / 9 / 2019$ & 52.05226 & 4.177227 & 6 & -500 \\
\hline 2019_055 & $24 / 9 / 2019$ & 52.0533 & 4.175206 & 6 & -696 \\
\hline 2019_056 & $24 / 9 / 2019$ & 52.05383 & 4.174114 & 6 & -804 \\
\hline 2019_057 & $18 / 9 / 2015$ & 52.05453 & 4.172772 & 6 & -903 \\
\hline 2019_058 & $17 / 9 / 2019$ & 52.05519 & 4.1715 & 6 & -996 \\
\hline 2019_059 & $17 / 9 / 2019$ & 52.05584 & 4.170252 & 6 & -1102 \\
\hline 2019_060 & $16 / 9 / 2019$ & 52.0563 & 4.169301 & 6 & -1149 \\
\hline 2019_062 & $23 / 9 / 2019$ & 52.05821 & 4.183864 & 7 & -288 \\
\hline 2019_063 & $23 / 9 / 2019$ & 52.05839 & 4.183494 & 7 & -425 \\
\hline 2019_064 & $23 / 9 / 2019$ & 52.05874 & 4.182828 & 7 & -502 \\
\hline 2019_065 & $23 / 9 / 2019$ & 52.0597 & 4.18092 & 7 & -695 \\
\hline 2019_066 & $23 / 9 / 2019$ & 52.06023 & 4.179925 & 7 & -799 \\
\hline 2019_067 & $18 / 9 / 2019$ & 52.06112 & 4.178182 & 7 & -906 \\
\hline 2019_068 & $17 / 9 / 2019$ & 52.06174 & 4.176959 & 7 & -1007 \\
\hline 2019_069 & $17 / 9 / 2019$ & 52.06219 & 4.176082 & 7 & -1105 \\
\hline 2019_070 & $16 / 8 / 2019$ & 52.06249 & 4.175507 & 7 & -1153 \\
\hline 2019_071 & $23 / 9 / 2019$ & 52.06114 & 4.196415 & 8 & -158 \\
\hline 2019_072 & $23 / 9 / 2019$ & 52.06186 & 4.195018 & 8 & -416 \\
\hline 2019_073 & $23 / 9 / 2019$ & 52.06225 & 4.194243 & 8 & -306 \\
\hline 2019_074 & $23 / 9 / 2019$ & 52.06269 & 4.193374 & 8 & -494 \\
\hline 2019_075 & $18 / 9 / 2019$ & 52.06353 & 4.191733 & 8 & -702 \\
\hline 2019_076 & $18 / 9 / 2019$ & 52.06448 & 4.189884 & 8 & -804 \\
\hline 2019_077 & $18 / 9 / 2019$ & 52.06534 & 4.188192 & 8 & -896 \\
\hline 2019_078 & $18 / 9 / 2019$ & 52.06597 & 4.186963 & 8 & -992 \\
\hline 2019_079 & $17 / 9 / 2019$ & 52.06691 & 4.1851 & 8 & -1098 \\
\hline 2019_080 & $17 / 9 / 2019$ & 52.0675 & 4.183955 & 8 & -1152 \\
\hline 2019_081 & $23 / 9 / 2019$ & 52.06682 & 4.208155 & 9 & -161 \\
\hline 2019_082 & $24 / 9 / 2019$ & 52.06781 & 4.206216 & 9 & -500 \\
\hline 2019_083 & $24 / 9 / 2019$ & 52.06821 & 4.205426 & 9 & -409 \\
\hline 2019_084 & $24 / 9 / 2019$ & 52.06849 & 4.204863 & 9 & -503 \\
\hline 2019_085 & $24 / 9 / 2019$ & 52.06902 & 4.203858 & 9 & -696 \\
\hline 2019_086 & $24 / 9 / 2019$ & 52.06942 & 4.203066 & 9 & -796 \\
\hline 2019_087 & $24 / 9 / 2019$ & 52.07013 & 4.20167 & 9 & -900 \\
\hline 2019_088 & $18 / 9 / 2019$ & 52.07153 & 4.198935 & 9 & -1000 \\
\hline 2019_089 & $17 / 9 / 2019$ & 52.07337 & 4.195319 & 9 & -1101 \\
\hline 2019_090 & $17 / 9 / 2019$ & 52.07465 & 4.192798 & 9 & -1152 \\
\hline 2019_092 & $23 / 9 / 2019$ & 52.07387 & 4.217226 & 10 & -525 \\
\hline 2019_093 & $24 / 9 / 2019$ & 52.07446 & 4.216057 & 10 & -408 \\
\hline 2019_094 & $24 / 9 / 2019$ & 52.07481 & 4.215386 & 10 & -505 \\
\hline 2019_095 & $24 / 9 / 2019$ & 52.07523 & 4.214555 & 10 & -701 \\
\hline 2019_096 & $24 / 9 / 2019$ & 52.07561 & 4.213824 & 10 & -797 \\
\hline 2019_097 & $24 / 9 / 2019$ & 52.07628 & 4.212469 & 10 & -899 \\
\hline 2019_098 & $18 / 9 / 2019$ & 52.07781 & 4.209495 & 10 & -1001 \\
\hline 2019_099 & $17 / 9 / 2019$ & 52.07999 & 4.205227 & 10 & -1100 \\
\hline 2019_100 & $17 / 9 / 2019$ & 52.08136 & 4.202557 & 10 & -1153 \\
\hline
\end{tabular}




\begin{tabular}{|c|c|c|c|c|c|}
\hline StationNr & Datum & $\begin{array}{l}\text { Latitude } \\
\text { (WGS84) }\end{array}$ & $\begin{array}{l}\text { Longitude } \\
\text { (WGS84) }\end{array}$ & Transect & $\begin{array}{l}\text { Diepte } \\
\text { (cm NAP) }\end{array}$ \\
\hline 2019_102 & 23/9/2019 & 52.08027 & 4.227538 & 11 & -443 \\
\hline 2019_103 & 24/9/2019 & 52.08087 & 4.226364 & 11 & -332 \\
\hline 2019_104 & 24/9/2019 & 52.08125 & 4.225601 & 11 & -505 \\
\hline 2019_105 & 24/9/2019 & 52.08165 & 4.224819 & 11 & -699 \\
\hline 2019_106 & 24/9/2019 & 52.08215 & 4.223841 & 11 & -797 \\
\hline 2019_107 & 24/9/2019 & 52.083 & 4.222191 & 11 & -901 \\
\hline 2019_108 & $18 / 9 / 2019$ & 52.08481 & 4.218657 & 11 & -1002 \\
\hline 2019_109 & $17 / 9 / 2019$ & 52.08756 & 4.213261 & 11 & -1100 \\
\hline 2019_110 & $17 / 9 / 2019$ & 52.0886 & 4.211211 & 11 & -1150 \\
\hline 2019_112 & 23/9/2019 & 52.0873 & 4.236611 & 12 & -481 \\
\hline 2019_113 & $24 / 9 / 2019$ & 52.0879 & 4.235444 & 12 & -345 \\
\hline 2019_114 & 24/9/2019 & 52.08823 & 4.234817 & 12 & -492 \\
\hline 2019_115 & $24 / 9 / 2019$ & 52.08866 & 4.233941 & 12 & -695 \\
\hline 2019_116 & 24/9/2019 & 52.08914 & 4.233019 & 12 & -804 \\
\hline 2019_117 & $24 / 9 / 2019$ & 52.09066 & 4.230061 & 12 & -899 \\
\hline 2019_118 & $18 / 9 / 2019$ & 52.09227 & 4.226909 & 12 & -1002 \\
\hline 2019_119 & $17 / 9 / 2019$ & 52.09388 & 4.223731 & 12 & -1100 \\
\hline 2019_120 & $17 / 9 / 2019$ & 52.09466 & 4.222226 & 12 & -1146 \\
\hline
\end{tabular}




\section{Bijlage 2 Bemonsteringslocaties Van Veen monsters}

\begin{tabular}{|c|c|c|c|c|c|c|}
\hline Tabel 9: & $\begin{array}{l}\text { Locaties bemo } \\
\text { gegeven in de } \\
\text { De diepte (cm } \\
\text { dieptekaart va } \\
\text { Research (WM } \\
\text { uitgezocht. }\end{array}$ & $\begin{array}{l}\text { met de V } \\
\text { graden (V } \\
\text { NAP) is be } \\
\text { ustus } 2019 \\
\text { Eurofins Ac }\end{array}$ & $\begin{array}{l}\text { (een happer } \\
\text { 84). Op dez } \\
\text { ld aan de ha } \\
\text { de laatste } \\
\text { Sense / Bure }\end{array}$ & $\begin{array}{l}\text { 2019. De } \\
\text { caties zijn } \\
\text { van de lig } \\
\text { W is aang } \\
\text { Waardenb }\end{array}$ & $\begin{array}{l}\text { rdinaten } \\
\text { vens sedi } \\
\text { hg van de } \\
\text { even welk } \\
\text { g (Eurofin }\end{array}$ & $\begin{array}{l}\text { de locaties } \\
\text { tmonsters } \\
\text { ties op de } \\
\text { Wagenin } \\
\text { t benthos }\end{array}$ \\
\hline Station $\mathrm{Nr}$ & Datum & $\begin{array}{l}\text { Latitude } \\
\text { (WGS84) }\end{array}$ & $\begin{array}{l}\text { Longitude } \\
\text { (WGS84) }\end{array}$ & Transect & $\begin{array}{l}\text { Diepte } \\
\text { (cm NAP) }\end{array}$ & Lab \\
\hline 2019_003 & 19/9/2019 & 52.00852 & 4.130333 & 0 & -223 & Eurofins \\
\hline 2019_004 & 19/9/2019 & 52.00983 & 4.1278 & 0 & -508 & WMR \\
\hline 2019_005 & 19/9/2019 & 52.01087 & 4.125785 & 0 & -708 & Eurofins \\
\hline 2019_006 & 19/9/2019 & 52.01158 & 4.12435 & 0 & -799 & WMR \\
\hline 2019_007 & 19/9/2019 & 52.01283 & 4.121933 & 0 & -901 & Eurofins \\
\hline 2019_008 & 19/9/2019 & 52.01537 & 4.116938 & 0 & -998 & WMR \\
\hline 2019_009 & 19/9/2019 & 52.01845 & 4.11092 & 0 & -1105 & Eurofins \\
\hline 2019_010 & 19/9/2019 & 52.02025 & 4.107396 & 0 & -1151 & WMR \\
\hline 2019_011 & 19/9/2019 & 52.01518 & 4.140142 & 1 & -165 & Eurofins \\
\hline 2019_012 & $19 / 9 / 2019$ & 52.01596 & 4.138641 & 1 & -480 & WMR \\
\hline 2019_013 & $19 / 9 / 2019$ & 52.01628 & 4.138001 & 1 & -319 & Eurofins \\
\hline 2019_014 & $19 / 9 / 2019$ & 52.01678 & 4.137035 & 1 & -491 & WMR \\
\hline 2019_015 & 19/9/2019 & 52.01778 & 4.135088 & 1 & -696 & Eurofins \\
\hline 2019_016 & 19/9/2019 & 52.01832 & 4.134006 & 1 & -809 & WMR \\
\hline 2019_017 & 19/9/2019 & 52.0192 & 4.132299 & 1 & -907 & Eurofins \\
\hline 2019_018 & $19 / 9 / 2019$ & 52.0209 & 4.128922 & 1 & -1000 & WMR \\
\hline 2019_019 & 19/9/2019 & 52.02389 & 4.123075 & 1 & -1101 & Eurofins \\
\hline 2019_020 & $19 / 9 / 2019$ & 52.02575 & 4.119466 & 1 & -1151 & WMR \\
\hline 2019_021 & $19 / 9 / 2019$ & 52.02203 & 4.149606 & 2 & -183 & Eurofins \\
\hline 2019_022 & 19/9/2019 & 52.02244 & 4.148829 & 2 & -401 & WMR \\
\hline 2019_023 & 19/9/2019 & 52.02289 & 4.147899 & 2 & -278 & Eurofins \\
\hline 2019_024 & 19/9/2019 & 52.02369 & 4.146367 & 2 & -504 & WMR \\
\hline 2019_025 & 19/9/2019 & 52.02518 & 4.143413 & 2 & -708 & Eurofins \\
\hline 2019_026 & $19 / 9 / 2019$ & 52.02561 & 4.142582 & 2 & -796 & WMR \\
\hline 2019_027 & 19/9/2019 & 52.02609 & 4.141643 & 2 & -901 & Eurofins \\
\hline 2019_028 & $19 / 9 / 2019$ & 52.02681 & 4.140237 & 2 & -998 & WMR \\
\hline 2019_029 & $19 / 9 / 2019$ & 52.0288 & 4.136324 & 2 & -1100 & Eurofins \\
\hline 2019_030 & $19 / 9 / 2019$ & 52.03126 & 4.131514 & 2 & -1151 & WMR \\
\hline 2019_031 & 19/9/2019 & 52.02941 & 4.158008 & 3 & -149 & Eurofins \\
\hline 2019_032 & 19/9/2019 & 52.03027 & 4.156301 & 3 & -436 & WMR \\
\hline 2019_033 & 19/9/2019 & 52.03065 & 4.155572 & 3 & -290 & Eurofins \\
\hline 2019_034 & 19/9/2019 & 52.03144 & 4.154029 & 3 & -500 & WMR \\
\hline 2019_035 & 19/9/2019 & 52.03225 & 4.152423 & 3 & -702 & Eurofins \\
\hline 2019_036 & 19/9/2019 & 52.03265 & 4.15164 & 3 & -802 & WMR \\
\hline 2019_037 & 19/9/2019 & 52.03311 & 4.150768 & 3 & -897 & Eurofins \\
\hline 2019_038 & 19/9/2019 & 52.03356 & 4.149884 & 3 & -999 & WMR \\
\hline 2019_039 & 19/9/2019 & 52.03704 & 4.14307 & 3 & -1102 & Eurofins \\
\hline 2019_040 & 19/9/2019 & 52.03875 & 4.139717 & 3 & -1153 & WMR \\
\hline 2019_041 & 19/9/2019 & 52.04414 & 4.174872 & 5 & -128 & Eurofins \\
\hline 2019_042 & $19 / 9 / 2019$ & 52.04494 & 4.173298 & 5 & -399 & WMR \\
\hline
\end{tabular}




\begin{tabular}{|c|c|c|c|c|c|c|}
\hline StationNr & Datum & $\begin{array}{l}\text { Latitude } \\
\text { (WGS84) }\end{array}$ & $\begin{array}{l}\text { Longitude } \\
\text { (WGS84) }\end{array}$ & Transect & $\begin{array}{c}\text { Diepte } \\
\text { (cm NAP) }\end{array}$ & Lab \\
\hline 2019_043 & 19/9/2019 & 52.04558 & 4.172039 & 5 & -321 & Eurofins \\
\hline 2019_044 & 19/9/2019 & 52.04599 & 4.17124 & 5 & -505 & WMR \\
\hline 2019_045 & 19/9/2019 & 52.0463 & 4.17064 & 5 & -683 & Eurofins \\
\hline 2019_046 & 19/9/2019 & 52.04655 & 4.170126 & 5 & -788 & WMR \\
\hline 2019_047 & 19/9/2019 & 52.0474 & 4.168486 & 5 & -900 & Eurofins \\
\hline 2019_048 & 19/9/2019 & 52.04852 & 4.1663 & 5 & -1000 & WMR \\
\hline 2019_049 & 19/9/2019 & 52.05079 & 4.16185 & 5 & -1090 & Eurofins \\
\hline 2019_050 & 19/9/2019 & 52.052 & 4.159444 & 5 & -1143 & WMR \\
\hline 2019_051 & 19/9/2019 & 52.05059 & 4.18051 & 6 & -125 & Eurofins \\
\hline 2019_052 & 19/9/2019 & 52.05097 & 4.17976 & 6 & -424 & WMR \\
\hline 2019_053 & 19/9/2019 & 52.05159 & 4.178558 & 6 & -245 & Eurofins \\
\hline 2019_054 & 19/9/2019 & 52.05226 & 4.177227 & 6 & -500 & WMR \\
\hline 2019_055 & 19/9/2019 & 52.0533 & 4.175206 & 6 & -696 & Eurofins \\
\hline 2019_056 & 19/9/2019 & 52.05383 & 4.174114 & 6 & -804 & WMR \\
\hline 2019_057 & 19/9/2019 & 52.05453 & 4.172772 & 6 & -903 & Eurofins \\
\hline 2019_058 & 19/9/2019 & 52.05519 & 4.1715 & 6 & -996 & WMR \\
\hline 2019_059 & 19/9/2019 & 52.05584 & 4.170252 & 6 & -1102 & Eurofins \\
\hline 2019_060 & 19/9/2019 & 52.0563 & 4.169301 & 6 & -1149 & WMR \\
\hline 2019_062 & 19/9/2019 & 52.05821 & 4.183864 & 7 & -288 & WMR \\
\hline 2019_063 & 19/9/2019 & 52.05839 & 4.183494 & 7 & -425 & Eurofins \\
\hline 2019_064 & 19/9/2019 & 52.05874 & 4.182828 & 7 & -502 & WMR \\
\hline 2019_065 & 19/9/2019 & 52.0597 & 4.18092 & 7 & -695 & Eurofins \\
\hline 2019_066 & 19/9/2019 & 52.06023 & 4.179925 & 7 & -799 & WMR \\
\hline 2019_067 & 19/9/2019 & 52.06112 & 4.178182 & 7 & -906 & Eurofins \\
\hline 2019_068 & 19/9/2019 & 52.06174 & 4.176959 & 7 & -1007 & WMR \\
\hline 2019_069 & 19/9/2019 & 52.06219 & 4.176082 & 7 & -1105 & Eurofins \\
\hline 2019_070 & 19/9/2019 & 52.06249 & 4.175507 & 7 & -1153 & WMR \\
\hline 2019_071 & 19/9/2019 & 52.06114 & 4.196415 & 8 & -158 & Eurofins \\
\hline 2019_072 & 19/9/2019 & 52.06186 & 4.195018 & 8 & -416 & WMR \\
\hline 2019_073 & 19/9/2019 & 52.06225 & 4.194243 & 8 & -306 & Eurofins \\
\hline 2019_074 & 19/9/2019 & 52.06269 & 4.193374 & 8 & -494 & WMR \\
\hline 2019_075 & 19/9/2019 & 52.06353 & 4.191733 & 8 & -702 & Eurofins \\
\hline 2019_076 & 19/9/2019 & 52.06448 & 4.189884 & 8 & -804 & WMR \\
\hline 2019_077 & 19/9/2019 & 52.06534 & 4.188192 & 8 & -896 & Eurofins \\
\hline 2019_078 & 19/9/2019 & 52.06597 & 4.186963 & 8 & -992 & WMR \\
\hline 2019_079 & 19/9/2019 & 52.06691 & 4.1851 & 8 & -1098 & Eurofins \\
\hline 2019_080 & 19/9/2019 & 52.0675 & 4.183955 & 8 & -1152 & WMR \\
\hline 2019_081 & 19/9/2019 & 52.06682 & 4.208155 & 9 & -161 & Eurofins \\
\hline 2019_082 & 19/9/2019 & 52.06781 & 4.206216 & 9 & -500 & WMR \\
\hline 2019_083 & 19/9/2019 & 52.06821 & 4.205426 & 9 & -409 & Eurofins \\
\hline 2019_084 & 19/9/2019 & 52.06849 & 4.204863 & 9 & -503 & WMR \\
\hline 2019_085 & 19/9/2019 & 52.06902 & 4.203858 & 9 & -696 & Eurofins \\
\hline 2019_086 & 19/9/2019 & 52.06942 & 4.203066 & 9 & -796 & WMR \\
\hline 2019_087 & 19/9/2019 & 52.07013 & 4.20167 & 9 & -900 & Eurofins \\
\hline 2019_088 & 19/9/2019 & 52.07153 & 4.198935 & 9 & -1000 & WMR \\
\hline 2019_089 & 19/9/2019 & 52.07337 & 4.195319 & 9 & -1101 & Eurofins \\
\hline 2019_090 & 19/9/2019 & 52.07465 & 4.192798 & 9 & -1152 & WMR \\
\hline 2019_091 & 19/9/2019 & 52.0728 & 4.219289 & 10 & -154 & Eurofins \\
\hline 2019_092 & 19/9/2019 & 52.07387 & 4.217226 & 10 & -525 & WMR \\
\hline 2019_093 & 19/9/2019 & 52.07446 & 4.216057 & 10 & -408 & Eurofins \\
\hline 2019_094 & 19/9/2019 & 52.07481 & 4.215386 & 10 & -505 & WMR \\
\hline 2019_095 & 19/9/2019 & 52.07523 & 4.214555 & 10 & -701 & Eurofins \\
\hline 2019_096 & 19/9/2019 & 52.07561 & 4.213824 & 10 & -797 & WMR \\
\hline
\end{tabular}




\begin{tabular}{|c|c|c|c|c|c|c|}
\hline StationNr & Datum & $\begin{array}{l}\text { Latitude } \\
\text { (WGS84) }\end{array}$ & $\begin{array}{l}\text { Longitude } \\
\text { (WGS84) }\end{array}$ & Transect & $\begin{array}{c}\text { Diepte } \\
\text { (cm NAP) }\end{array}$ & Lab \\
\hline 2019_097 & $19 / 9 / 2019$ & 52.07628 & 4.212469 & 10 & -899 & Eurofins \\
\hline 2019_098 & $19 / 9 / 2019$ & 52.07781 & 4.209495 & 10 & -1001 & WMR \\
\hline 2019_099 & $19 / 9 / 2019$ & 52.07999 & 4.205227 & 10 & -1100 & Eurofins \\
\hline 2019_100 & $19 / 9 / 2019$ & 52.08136 & 4.202557 & 10 & -1153 & WMR \\
\hline 2019_101 & $19 / 9 / 2019$ & 52.07948 & 4.229072 & 11 & -142 & Eurofins \\
\hline 2019_102 & $19 / 9 / 2019$ & 52.08027 & 4.227538 & 11 & -443 & WMR \\
\hline 2019_103 & $19 / 9 / 2019$ & 52.08087 & 4.226364 & 11 & -332 & Eurofins \\
\hline 2019_104 & $19 / 9 / 2019$ & 52.08125 & 4.225601 & 11 & -505 & WMR \\
\hline 2019_105 & $19 / 9 / 2019$ & 52.08165 & 4.224819 & 11 & -699 & Eurofins \\
\hline 2019_106 & $19 / 9 / 2019$ & 52.08215 & 4.223841 & 11 & -797 & WMR \\
\hline 2019_107 & $19 / 9 / 2019$ & 52.083 & 4.222191 & 11 & -901 & Eurofins \\
\hline 2019_108 & $19 / 9 / 2019$ & 52.08481 & 4.218657 & 11 & -1002 & WMR \\
\hline 2019_109 & $19 / 9 / 2019$ & 52.08756 & 4.213261 & 11 & -1100 & Eurofins \\
\hline 2019_110 & $19 / 9 / 2019$ & 52.0886 & 4.211211 & 11 & -1150 & WMR \\
\hline 2019_111 & $19 / 9 / 2019$ & 52.08625 & 4.238671 & 12 & -85 & Eurofins \\
\hline 2019_112 & $19 / 9 / 2019$ & 52.0873 & 4.236611 & 12 & -481 & WMR \\
\hline 2019_113 & $19 / 9 / 2019$ & 52.0879 & 4.235444 & 12 & -345 & Eurofins \\
\hline 2019_114 & $19 / 9 / 2019$ & 52.08823 & 4.234817 & 12 & -492 & WMR \\
\hline 2019_115 & $19 / 9 / 2019$ & 52.08866 & 4.233941 & 12 & -695 & Eurofins \\
\hline 2019_116 & $19 / 9 / 2019$ & 52.08914 & 4.233019 & 12 & -804 & WMR \\
\hline 2019_117 & $19 / 9 / 2019$ & 52.09066 & 4.230061 & 12 & -899 & Eurofins \\
\hline 2019_118 & $19 / 9 / 2019$ & 52.09227 & 4.226909 & 12 & -1002 & WMR \\
\hline 2019_119 & $19 / 9 / 2019$ & 52.09388 & 4.223731 & 12 & -1100 & Eurofins \\
\hline 2019_120 & $19 / 9 / 2019$ & 52.09466 & 4.222226 & 12 & -1146 & WMR \\
\hline
\end{tabular}




\section{Bijlage 3 Bemonsteringslocaties Strand}

Tabel 10: Locaties bemonsterd op het strand in 2019. De cöordinaten van de locaties zijn gegeven in decimale graden (WGS84). Op deze locaties zijn tevens sedimentmonsters genomen. In de laatste kolom is aangegeven welk lab, Wageningen Marine Research (WMR) of Eurofins AquaSense / Bureau Waardenburg (Eurofins) het benthos heeft uitgezocht.

\begin{tabular}{|c|c|c|c|c|c|}
\hline StationNr & Datum & $\begin{array}{l}\text { Latitude } \\
\text { (WGS84) }\end{array}$ & $\begin{array}{l}\text { Longitude } \\
\text { (WGS84) }\end{array}$ & Transect & Lab \\
\hline 2019_121 & $4 / 10 / 2019$ & 52.00757 & 4.132227 & 0 & Eurofins \\
\hline 2019_122 & $4 / 10 / 2019$ & 52.00747 & 4.13242 & 0 & WMR \\
\hline 2019_123 & $4 / 10 / 2019$ & 52.00734 & 4.132674 & 0 & Eurofins \\
\hline 2019_124 & $4 / 10 / 2019$ & 52.00725 & 4.132856 & 0 & WMR \\
\hline 2019_125 & $4 / 10 / 2019$ & 52.00715 & 4.133045 & 0 & Eurofins \\
\hline 2019_126 & $4 / 10 / 2019$ & 52.01451 & 4.141484 & 1 & WMR \\
\hline 2019_127 & $4 / 10 / 2019$ & 52.01448 & 4.141533 & 1 & Eurofins \\
\hline 2019_128 & $4 / 10 / 2019$ & 52.0144 & 4.141702 & 1 & WMR \\
\hline 2019_129 & $4 / 10 / 2019$ & 52.01433 & 4.141837 & 1 & Eurofins \\
\hline 2019_130 & $4 / 10 / 2019$ & 52.01422 & 4.142042 & 1 & WMR \\
\hline 2019_131 & $4 / 10 / 2019$ & 52.02157 & 4.150498 & 2 & Eurofins \\
\hline 2019_132 & $4 / 10 / 2019$ & 52.02154 & 4.150569 & 2 & WMR \\
\hline 2019_133 & $4 / 10 / 2019$ & 52.0214 & 4.150845 & 2 & Eurofins \\
\hline 2019_134 & $4 / 10 / 2019$ & 52.0213 & 4.151033 & 2 & WMR \\
\hline 2019_135 & $4 / 10 / 2019$ & 52.02124 & 4.151153 & 2 & Eurofins \\
\hline 2019_136 & $4 / 10 / 2019$ & 52.0289 & 4.158994 & 3 & WMR \\
\hline 2019_137 & $4 / 10 / 2019$ & 52.02887 & 4.159056 & 3 & Eurofins \\
\hline 2019_138 & $4 / 10 / 2019$ & 52.0287 & 4.159399 & 3 & WMR \\
\hline 2019_139 & $4 / 10 / 2019$ & 52.0286 & 4.159592 & 3 & Eurofins \\
\hline 2019_140 & $4 / 10 / 2019$ & 52.02851 & 4.159757 & 3 & WMR \\
\hline 2019_141 & $4 / 10 / 2019$ & 52.04363 & 4.175851 & 5 & Eurofins \\
\hline 2019_142 & $4 / 10 / 2019$ & 52.04361 & 4.175887 & 5 & WMR \\
\hline 2019_143 & $4 / 10 / 2019$ & 52.04356 & 4.175985 & 5 & Eurofins \\
\hline 2019_144 & $4 / 10 / 2019$ & 52.04354 & 4.176038 & 5 & WMR \\
\hline 2019_145 & $4 / 10 / 2019$ & 52.04347 & 4.176166 & 5 & Eurofins \\
\hline 2019_146 & $4 / 10 / 2019$ & 52.05032 & 4.181033 & 6 & WMR \\
\hline 2019_147 & $4 / 10 / 2019$ & 52.05023 & 4.181207 & 6 & Eurofins \\
\hline 2019_148 & $4 / 10 / 2019$ & 52.05015 & 4.181366 & 6 & WMR \\
\hline 2019_149 & $4 / 10 / 2019$ & 52.05006 & 4.18154 & 6 & Eurofins \\
\hline 2019_150 & $4 / 10 / 2019$ & 52.05001 & 4.181637 & 6 & WMR \\
\hline 2019_151 & $4 / 10 / 2019$ & 52.05642 & 4.187386 & 7 & Eurofins \\
\hline 2019_152 & $4 / 10 / 2019$ & 52.05638 & 4.187457 & 7 & WMR \\
\hline 2019_153 & $4 / 10 / 2019$ & 52.05632 & 4.187572 & 7 & Eurofins \\
\hline 2019_154 & $4 / 10 / 2019$ & 52.0563 & 4.187613 & 7 & WMR \\
\hline 2019_155 & $4 / 10 / 2019$ & 52.0562 & 4.187813 & 7 & Eurofins \\
\hline 2019_156 & $3 / 10 / 2019$ & 52.06091 & 4.196862 & 8 & WMR \\
\hline 2019_157 & $3 / 10 / 2019$ & 52.06078 & 4.197128 & 8 & Eurofins \\
\hline 2019_158 & $3 / 10 / 2019$ & 52.06067 & 4.197336 & 8 & WMR \\
\hline 2019_159 & $3 / 10 / 2019$ & 52.06045 & 4.197762 & 8 & Eurofins \\
\hline 2019_160 & $3 / 10 / 2019$ & 52.06015 & 4.198349 & 8 & WMR \\
\hline 2019_161 & $3 / 10 / 2019$ & 52.06598 & 4.209782 & 9 & Eurofins \\
\hline 2019_162 & $3 / 10 / 2019$ & 52.06594 & 4.209865 & 9 & WMR \\
\hline 2019_163 & $3 / 10 / 2019$ & 52.06581 & 4.210131 & 9 & Eurofins \\
\hline
\end{tabular}




\begin{tabular}{|c|c|c|c|c|c|}
\hline StationNr & Datum & $\begin{array}{l}\text { Latitude } \\
\text { (WGS84) }\end{array}$ & $\begin{array}{l}\text { Longitude } \\
\text { (WGS84) }\end{array}$ & Transect & Lab \\
\hline 2019_164 & $3 / 10 / 2019$ & 52.06569 & 4.210358 & 9 & WMR \\
\hline 2019_165 & $3 / 10 / 2019$ & 52.06565 & 4.210438 & 9 & Eurofins \\
\hline 2019_166 & $3 / 10 / 2019$ & 52.07225 & 4.220377 & 10 & WMR \\
\hline 2019_167 & $3 / 10 / 2019$ & 52.0722 & 4.220468 & 10 & Eurofins \\
\hline 2019_168 & $3 / 10 / 2019$ & 52.07204 & 4.220787 & 10 & WMR \\
\hline 2019_169 & $3 / 10 / 2019$ & 52.07195 & 4.220951 & 10 & Eurofins \\
\hline 2019_170 & $3 / 10 / 2019$ & 52.07191 & 4.22104 & 10 & WMR \\
\hline 2019_171 & $3 / 10 / 2019$ & 52.07908 & 4.229849 & 11 & Eurofins \\
\hline 2019_172 & $3 / 10 / 2019$ & 52.07902 & 4.229968 & 11 & WMR \\
\hline 2019_173 & $3 / 10 / 2019$ & 52.07883 & 4.230335 & 11 & Eurofins \\
\hline 2019_174 & $3 / 10 / 2019$ & 52.07872 & 4.23055 & 11 & WMR \\
\hline 2019_175 & $3 / 10 / 2019$ & 52.07868 & 4.230634 & 11 & Eurofins \\
\hline 2019_176 & $3 / 10 / 2019$ & 52.08587 & 4.239425 & 12 & WMR \\
\hline 2019_177 & $3 / 10 / 2019$ & 52.0858 & 4.239557 & 12 & Eurofins \\
\hline 2019_178 & $3 / 10 / 2019$ & 52.0856 & 4.239948 & 12 & WMR \\
\hline 2019_179 & $3 / 10 / 2019$ & 52.08545 & 4.240233 & 12 & Eurofins \\
\hline 2019_180 & $3 / 10 / 2019$ & 52.08538 & 4.240375 & 12 & WMR \\
\hline 2019_196 & $3 / 10 / 2019$ & 52.0591 & 4.200413 & 8 & WMR \\
\hline 2019_197 & $3 / 10 / 2019$ & 52.05923 & 4.200162 & 8 & Eurofins \\
\hline 2019_198 & $3 / 10 / 2019$ & 52.05933 & 4.199965 & 8 & WMR \\
\hline 2019_199 & $3 / 10 / 2019$ & 52.05945 & 4.199728 & 8 & Eurofins \\
\hline 2019_200 & $3 / 10 / 2019$ & 52.05957 & 4.199483 & 8 & WMR \\
\hline 2019_201 & $3 / 10 / 2019$ & 52.05346 & 4.193178 & 7 & Eurofins \\
\hline 2019_202 & $3 / 10 / 2019$ & 52.05342 & 4.193241 & 7 & WMR \\
\hline 2019_203 & $3 / 10 / 2019$ & 52.05339 & 4.193316 & 7 & Eurofins \\
\hline 2019_204 & $3 / 10 / 2019$ & 52.05338 & 4.19333 & 7 & WMR \\
\hline 2019_205 & $3 / 10 / 2019$ & 52.05337 & 4.193355 & 7 & Eurofins \\
\hline
\end{tabular}




\section{Bijlage 4 Correcties taxa Van Veen en strand}

In Tabel 11 is een overzicht gegeven van de correcties die zijn uitgevoerd op de Van Veen en strand data alvorens deze zijn geanalyseerd.

Tabel 11: Correcties taxa van Veen bemonsering voor de analyse. In de eerste kolom de oorspronkelijke naamgeving. In de tweede kolom het aantal records met deze naam. De derde kolom geeft de aangepaste naam en de vierde kolom geeft het oorspronkelijk aantal records met deze aangepaste naam.

\begin{tabular}{|c|c|c|c|}
\hline Taxon & \#Records & Aangepast naar & \#Records \\
\hline Dendrobrachiata/Caridea & 1 & Caridea & 10 \\
\hline Abra & 3 & Abra alba & 703 \\
\hline Mya & 1 & Mya arenaria & 11 \\
\hline Aphelochaeta marioni & 4 & Cirratulidae & 23 \\
\hline Capitella capitata & 152 & Capitella & 110 \\
\hline Capitellidae & 10 & Capitella & 110 \\
\hline Echinocardium & 1 & Echinocardium cordatum & 54 \\
\hline Ensis leei & 33 & Ensis & 1891 \\
\hline Eteone longa & 91 & Eteone & 83 \\
\hline Eteone flava & 59 & Eteone & 83 \\
\hline Eteoninae & 29 & Eteone & 83 \\
\hline Euspira & 7 & Euspira nitida & 63 \\
\hline Fabulina & 1 & Fabulina fabula & 1200 \\
\hline Grania & 2 & Grania postclitellochaeta & 10 \\
\hline Harmothoe imbricata & 1 & Harmothoe & 14 \\
\hline Harmothoe impar & 1 & Harmothoe & 14 \\
\hline Jaera & 1 & Jaera (Jaera) albifrons & 3 \\
\hline Lanice & 7 & Lanice conchilega & 214 \\
\hline Liocarcinus & 21 & Liocarcinus holsatus & 49 \\
\hline Lutraria & 1 & Lutraria lutraria & 9 \\
\hline Malmgreniella & 29 & Malmgrenia & 17 \\
\hline Marenzelleria & 1 & Marenzelleria viridis & 1 \\
\hline Melita & 3 & Melitidae & 3 \\
\hline Microprotopus & 1 & Microprotopus maculatus & 39 \\
\hline Owenia fusiformis & 89 & Owenia & 22 \\
\hline Pectinaria & 1 & Pectinariidae & 5 \\
\hline Polynoinae & 1 & Polynoidae & 33 \\
\hline Processa parva & 2 & Processa modica modica & 12 \\
\hline Scolelepis & 41 & Scolelepis (Scolelepis) squamat & 510 \\
\hline Scoloplos & 19 & Scoloplos armiger & 184 \\
\hline Stenothoe & 1 & Stenothoe marina & 1 \\
\hline Streblospio & 9 & Streblospio benedicti & 8 \\
\hline Streblospio shrubsolii & 6 & Streblospio benedicti & 8 \\
\hline Tellina & 6 & Tellinidae & 3 \\
\hline Tharyx & 8 & Cirratulidae & 27 \\
\hline Urothoe & 4 & Urothoe poseidonis & 80 \\
\hline Venerupis & 1 & Venerupis corrugata & 2 \\
\hline Spisula & 63 & Spisula subtruncata & 951 \\
\hline Diastylis & 13 & Diastylis bradyi & \\
\hline
\end{tabular}




\begin{tabular}{|c|c|c|c|}
\hline Taxon & \#Records & Aangepast naar & \#Records \\
\hline Harmothoe & 16 & Malmgrenia & 150 \\
\hline Malmgrenia lunulata & 7 & Malmgrenia darbouxi & 46 \\
\hline Nephtys kersivalensis & 36 & Nephtys cirrosa & 83 \\
\hline Pariambus typicus & 63 & Caprellidae & 440 \\
\hline Eumida bahusiensis & 21 & Eumida & 33 \\
\hline Eumida sanguinea & 23 & Eumida & 33 \\
\hline Glycera tridactyla & 28 & Glycera & 37 \\
\hline Glycera alba & 2 & Glycera & 37 \\
\hline Spio filicornis & 2 & Spio & 12 \\
\hline Spio goniocephala & 6 & Spio & 12 \\
\hline Spio decorata & 9 & Spio & 12 \\
\hline Spio symphyta & 2 & Spio & 12 \\
\hline Spio martinensis & 336 & Spio & 12 \\
\hline Spionida & 4 & Spio & 12 \\
\hline Spionidae & 7 & Spio & 12 \\
\hline Phyllodoce & 3 & Phyllodocidae & 10 \\
\hline Ophiura & 41 & Ophiuroidea & 12 \\
\hline Ophiuridae & 9 & Ophiuroidea & 53 \\
\hline Nereidinae & 1 & Nereididae & 7 \\
\hline Mytilidae & 5 & Mytilus edulis & 46 \\
\hline Mysidae & 4 & Mysida & 18 \\
\hline Mactridae & 1 & Mactra stultorum & 2 \\
\hline Crangonidae & 7 & Crangon crangon & 104 \\
\hline Corophiidae & 7 & Corophium & 2 \\
\hline Balanidae & 2 & Cirripedia & 1 \\
\hline Grania postclitellochaeta & 12 & Oligochaeta & 56 \\
\hline Naididae & 1 & Oligochaeta & 56 \\
\hline Tubificoides benedii & 5 & Oligochaeta & 56 \\
\hline Tubificoides brownae & 1 & Oligochaeta & 56 \\
\hline Tubificoides diazi & 16 & Oligochaeta & 56 \\
\hline Alcyonidium parasiticum & 1 & Bryozoa & 11 \\
\hline Conopeum reticulum & 2 & Bryozoa & 11 \\
\hline Electra pilosa & 3 & Bryozoa & 11 \\
\hline Anthoathecata & 1 & Hydrozoa & 103 \\
\hline Campanulariidae & 17 & Hydrozoa & 103 \\
\hline Clytia hemisphaeric & 2 & Hydrozoa & 103 \\
\hline Leptothecata & 49 & Hydrozoa & 103 \\
\hline Obelia bidentata & 9 & Hydrozoa & 103 \\
\hline Obelia longissima & 1 & Hydrozoa & 103 \\
\hline Tubulariidae & 1 & Hydrozoa & 103 \\
\hline Tubulanus polymorphus & 12 & Nemertea & 223 \\
\hline
\end{tabular}




\section{Bijlage 5 Sedimentsamenstelling}

Tabel 12: Overzicht resultaten sedimentsamenstelling 2019. Aangegeven zijn de parameters mediane korrelgrootte $(\mu \mathrm{m})$, percentage silt $(<63 \mu \mathrm{m})$, percentage zeer fijn zand $(63-125 \mu \mathrm{m})$, percentage fijn zand $(125-250 \mu \mathrm{m})$, percentage medium zand $(250-500 \mu \mathrm{m})$ en percentage grof zand $(500-1000 \mu \mathrm{m})$.

\begin{tabular}{|c|c|c|c|c|c|c|c|c|}
\hline StationNr & $\begin{array}{l}\text { Latitude } \\
\text { (WGS84) }\end{array}$ & $\begin{array}{l}\text { Longitude } \\
\text { (WGS84) }\end{array}$ & $\begin{array}{l}\text { Mediaan } \\
\text { ( } \mu \mathrm{m})\end{array}$ & Silt (\%) & $\begin{array}{c}\text { Zeer fijn } \\
\text { zand }(\%)\end{array}$ & $\begin{array}{c}\text { Fijn zand } \\
(\%)\end{array}$ & $\begin{array}{l}\text { Medium } \\
\text { zand }(\%)\end{array}$ & $\begin{array}{c}\text { Grof zand } \\
(\%)\end{array}$ \\
\hline 2019_003 & 52.00852 & 4.13033 & 216.8 & 0.00 & 3.55 & 63.27 & 33.06 & 0.12 \\
\hline 2019_004 & 52.00983 & 4.12780 & 273.0 & 0.00 & 4.75 & 38.74 & 41.64 & 14.86 \\
\hline 2019_005 & 52.01087 & 4.12579 & 167.4 & 0.03 & 24.53 & 57.55 & 17.66 & 0.23 \\
\hline 2019_006 & 52.01158 & 4.12435 & 148.2 & 3.24 & 31.34 & 55.22 & 10.26 & 0.00 \\
\hline 2019_007 & 52.01283 & 4.12193 & 43.7 & 64.27 & 23.32 & 9.47 & 2.87 & 0.38 \\
\hline 2019_008 & 52.01537 & 4.11694 & 144.4 & 21.50 & 21.44 & 34.08 & 18.37 & 4.73 \\
\hline 2019_009 & 52.01845 & 4.11092 & 174.1 & 0.02 & 21.56 & 58.17 & 19.93 & 0.33 \\
\hline 2019_010 & 52.02025 & 4.10740 & 168.9 & 0.07 & 23.38 & 59.15 & 17.40 & 0.01 \\
\hline 2019_011 & 52.01518 & 4.14014 & 313.0 & 0.00 & 0.78 & 30.21 & 53.97 & 15.04 \\
\hline 2019_012 & 52.01596 & 4.13864 & 258.2 & 0.00 & 1.46 & 45.16 & 49.55 & 3.82 \\
\hline 2019_013 & 52.01628 & 4.13800 & 244.6 & 0.00 & 2.66 & 49.57 & 44.81 & 2.96 \\
\hline 2019_014 & 52.01678 & 4.13703 & 243.1 & 0.00 & 4.63 & 47.94 & 43.40 & 4.03 \\
\hline 2019_015 & 52.01778 & 4.13509 & 185.0 & 0.01 & 16.94 & 58.96 & 23.55 & 0.55 \\
\hline 2019_016 & 52.01832 & 4.13401 & 178.2 & 0.00 & 19.37 & 59.53 & 20.93 & 0.17 \\
\hline 2019_017 & 52.01920 & 4.13230 & 191.8 & 0.01 & 15.40 & 57.43 & 26.51 & 0.66 \\
\hline 2019_018 & 52.02090 & 4.12892 & 174.8 & 9.61 & 19.10 & 45.37 & 24.21 & 1.77 \\
\hline 2019_019 & 52.02389 & 4.12308 & 198.0 & 0.00 & 13.05 & 57.70 & 28.48 & 0.77 \\
\hline 2019_020 & 52.02575 & 4.11947 & 225.2 & 0.00 & 11.15 & 46.75 & 35.93 & 6.18 \\
\hline 2019_021 & 52.02203 & 4.14961 & 214.7 & 0.00 & 2.23 & 67.88 & 29.88 & 0.00 \\
\hline 2019_022 & 52.02244 & 4.14883 & 311.2 & 0.00 & 0.12 & 27.79 & 62.65 & 9.44 \\
\hline 2019_023 & 52.02289 & 4.14790 & 221.4 & 0.00 & 4.81 & 57.99 & 36.40 & 0.80 \\
\hline 2019_024 & 52.02369 & 4.14637 & 223.8 & 0.00 & 5.30 & 55.83 & 37.44 & 1.43 \\
\hline 2019_025 & 52.02518 & 4.14341 & 424.4 & 0.00 & 0.00 & 8.47 & 57.79 & 33.74 \\
\hline 2019_026 & 52.02561 & 4.14258 & 362.8 & 0.00 & 0.44 & 20.83 & 54.78 & 23.94 \\
\hline 2019_027 & 52.02609 & 4.14164 & 254.9 & 0.00 & 4.58 & 43.74 & 45.28 & 6.42 \\
\hline 2019_028 & 52.02681 & 4.14024 & 168.8 & 0.02 & 23.53 & 58.26 & 17.30 & 0.90 \\
\hline 2019_029 & 52.02880 & 4.13632 & 551.9 & 0.00 & 0.00 & 1.18 & 39.08 & 59.73 \\
\hline 2019_030 & 52.03126 & 4.13151 & 219.5 & 0.00 & 10.13 & 50.81 & 35.85 & 3.22 \\
\hline 2019_031 & 52.02941 & 4.15801 & 314.3 & 0.00 & 0.14 & 27.12 & 62.63 & 10.11 \\
\hline 2019_032 & 52.03027 & 4.15630 & 522.9 & 0.00 & 0.00 & 0.84 & 44.07 & 55.09 \\
\hline 2019_033 & 52.03065 & 4.15557 & 327.2 & 0.00 & 0.28 & 26.06 & 58.61 & 15.05 \\
\hline 2019_034 & 52.03144 & 4.15403 & 304.6 & 0.00 & 0.71 & 31.36 & 56.75 & 11.18 \\
\hline 2019_035 & 52.03225 & 4.15242 & 307.7 & 0.00 & 0.90 & 30.59 & 56.63 & 11.88 \\
\hline 2019_036 & 52.03265 & 4.15164 & 304.4 & 0.00 & 0.76 & 31.26 & 57.09 & 10.89 \\
\hline 2019_037 & 52.03311 & 4.15077 & 224.2 & 0.00 & 4.71 & 56.70 & 37.74 & 0.85 \\
\hline 2019_038 & 52.03356 & 4.14988 & 181.8 & 14.42 & 14.01 & 43.11 & 26.61 & 1.89 \\
\hline 2019_039 & 52.03704 & 4.14307 & 260.1 & 0.00 & 1.60 & 44.23 & 51.05 & 3.11 \\
\hline 2019_040 & 52.03875 & 4.13972 & 236.8 & 0.00 & 5.75 & 49.22 & 41.79 & 3.23 \\
\hline 2019_041 & 52.04414 & 4.17487 & 324.1 & 0.00 & 0.62 & 26.82 & 58.11 & 14.45 \\
\hline 2019_042 & 52.04494 & 4.17330 & 373.2 & 0.00 & 0.55 & 19.65 & 53.68 & 26.11 \\
\hline 2019_043 & 52.04558 & 4.17204 & 310.3 & 0.00 & 0.06 & 26.48 & 65.83 & 7.63 \\
\hline 2019_044 & 52.04599 & 4.17124 & 301.1 & 0.00 & 0.35 & 30.98 & 60.46 & 8.21 \\
\hline 2019_045 & 52.04630 & 4.17064 & 291.3 & 0.00 & 0.43 & 33.77 & 59.44 & 6.36 \\
\hline
\end{tabular}




\begin{tabular}{|c|c|c|c|c|c|c|c|c|}
\hline StationNr & $\begin{array}{l}\text { Latitude } \\
\text { (WGS84) }\end{array}$ & $\begin{array}{l}\text { Longitude } \\
\text { (WGS84) }\end{array}$ & $\begin{array}{l}\text { Mediaan } \\
\text { ( } \mu \mathrm{m})\end{array}$ & Silt ( $\%)$ & $\begin{array}{l}\text { Zeer fijn } \\
\text { zand }(\%)\end{array}$ & $\begin{array}{c}\text { Fijn zand } \\
(\%)\end{array}$ & $\begin{array}{l}\text { Medium } \\
\text { zand }(\%)\end{array}$ & $\begin{array}{c}\text { Grof zand } \\
(\%)\end{array}$ \\
\hline 2019_046 & 52.04655 & 4.17013 & 238.9 & 0.00 & 3.38 & 51.28 & 43.38 & 1.96 \\
\hline 2019_047 & 52.04740 & 4.16849 & 432.8 & 0.00 & 0.00 & 9.81 & 53.07 & 37.11 \\
\hline 2019_048 & 52.04852 & 4.16630 & 213.0 & 9.35 & 9.57 & 42.98 & 33.56 & 4.57 \\
\hline 2019_049 & 52.05079 & 4.16185 & 208.5 & 0.00 & 6.58 & 62.74 & 30.50 & 0.17 \\
\hline 2019_050 & 52.05200 & 4.15944 & 260.3 & 0.00 & 5.84 & 41.24 & 37.28 & 15.63 \\
\hline 2019_051 & 52.05059 & 4.18051 & 335.3 & 0.00 & 0.00 & 21.18 & 65.25 & 13.58 \\
\hline 2019_052 & 52.05097 & 4.17976 & 556.7 & 0.00 & 0.00 & 1.43 & 38.52 & 60.04 \\
\hline 2019_053 & 52.05159 & 4.17856 & 426.9 & 0.00 & 0.00 & 2.52 & 68.14 & 29.35 \\
\hline 2019_054 & 52.05226 & 4.17723 & 344.5 & 0.00 & 0.10 & 21.89 & 60.07 & 17.95 \\
\hline 2019_055 & 52.05330 & 4.17521 & 433.2 & 0.00 & 0.00 & 5.06 & 60.80 & 34.14 \\
\hline 2019_056 & 52.05383 & 4.17411 & 437.5 & 0.00 & 0.00 & 3.26 & 62.79 & 33.95 \\
\hline 2019_057 & 52.05453 & 4.17277 & 430.3 & 0.00 & 0.00 & 6.56 & 58.92 & 34.52 \\
\hline 2019_058 & 52.05519 & 4.17150 & 466.1 & 0.00 & 0.00 & 5.91 & 50.68 & 43.41 \\
\hline 2019_059 & 52.05584 & 4.17025 & 594.5 & 0.00 & 1.02 & 6.36 & 30.08 & 62.55 \\
\hline 2019_060 & 52.05630 & 4.16930 & 592.9 & 2.92 & 1.25 & 9.91 & 26.66 & 59.27 \\
\hline 2019_062 & 52.05821 & 4.18386 & 347.0 & 0.00 & 0.00 & 17.78 & 67.26 & 14.96 \\
\hline 2019_063 & 52.05839 & 4.18349 & 335.7 & 0.00 & 0.02 & 21.31 & 65.01 & 13.65 \\
\hline 2019_064 & 52.05874 & 4.18283 & 353.6 & 0.00 & 0.04 & 19.99 & 60.08 & 19.90 \\
\hline 2019_065 & 52.05970 & 4.18092 & 386.0 & 0.00 & 0.00 & 8.54 & 70.19 & 21.27 \\
\hline 2019_066 & 52.06023 & 4.17992 & 429.7 & 0.00 & 0.00 & 3.29 & 65.43 & 31.28 \\
\hline 2019_067 & 52.06112 & 4.17818 & 474.0 & 0.00 & 0.00 & 1.55 & 54.89 & 43.55 \\
\hline 2019_068 & 52.06174 & 4.17696 & 434.9 & 0.00 & 0.00 & 3.38 & 63.37 & 33.24 \\
\hline 2019_069 & 52.06219 & 4.17608 & 431.0 & 0.00 & 0.00 & 8.11 & 56.03 & 35.86 \\
\hline 2019_070 & 52.06249 & 4.17551 & 597.4 & 0.64 & 0.35 & 4.59 & 31.72 & 62.71 \\
\hline 2019_071 & 52.06114 & 4.19641 & 332.1 & 0.00 & 0.07 & 22.38 & 64.47 & 13.07 \\
\hline 2019_072 & 52.06186 & 4.19502 & 752.4 & 2.45 & 1.05 & 0.42 & 17.84 & 78.26 \\
\hline 2019_073 & 52.06225 & 4.19424 & 310.6 & 0.00 & 0.11 & 27.67 & 63.42 & 8.80 \\
\hline 2019_074 & 52.06269 & 4.19337 & 207.9 & 0.00 & 7.97 & 60.47 & 31.03 & 0.54 \\
\hline 2019_075 & 52.06353 & 4.19173 & 208.8 & 0.00 & 4.98 & 65.82 & 29.17 & 0.03 \\
\hline 2019_076 & 52.06448 & 4.18988 & 271.8 & 0.00 & 0.20 & 39.57 & 58.25 & 1.97 \\
\hline 2019_077 & 52.06534 & 4.18819 & 338.9 & 0.00 & 0.00 & 17.48 & 71.15 & 11.37 \\
\hline 2019_078 & 52.06597 & 4.18696 & 312.6 & 0.00 & 0.00 & 22.03 & 73.32 & 4.65 \\
\hline 2019_079 & 52.06691 & 4.18510 & 293.8 & 0.00 & 0.06 & 30.97 & 64.50 & 4.47 \\
\hline 2019_080 & 52.06750 & 4.18396 & 315.4 & 0.00 & 0.11 & 27.00 & 61.84 & 11.05 \\
\hline 2019_081 & 52.06682 & 4.20816 & 255.2 & 0.00 & 1.51 & 46.27 & 49.55 & 2.66 \\
\hline 2019_082 & 52.06781 & 4.20622 & 318.1 & 0.00 & 0.40 & 28.52 & 56.38 & 14.70 \\
\hline 2019_083 & 52.06821 & 4.20543 & 284.3 & 0.00 & 0.61 & 36.20 & 57.16 & 6.03 \\
\hline 2019_084 & 52.06849 & 4.20486 & 277.6 & 0.00 & 0.92 & 38.38 & 55.10 & 5.60 \\
\hline 2019_085 & 52.06902 & 4.20386 & 191.2 & 0.00 & 9.09 & 70.24 & 20.66 & 0.01 \\
\hline 2019_086 & 52.06942 & 4.20307 & 180.8 & 0.00 & 12.67 & 71.18 & 16.16 & 0.00 \\
\hline 2019_087 & 52.07013 & 4.20167 & 155.0 & 11.96 & 22.67 & 49.50 & 15.92 & 0.00 \\
\hline 2019_088 & 52.07153 & 4.19893 & 194.4 & 0.00 & 10.29 & 65.19 & 24.44 & 0.08 \\
\hline 2019_089 & 52.07337 & 4.19532 & 222.8 & 0.00 & 7.03 & 53.72 & 37.32 & 1.94 \\
\hline 2019_090 & 52.07465 & 4.19280 & 211.4 & 0.00 & 9.23 & 56.35 & 33.33 & 1.09 \\
\hline 2019_091 & 52.07280 & 4.21929 & 357.9 & 0.00 & 0.20 & 20.96 & 56.27 & 22.57 \\
\hline 2019_092 & 52.07387 & 4.21723 & 428.2 & 0.00 & 0.00 & 9.99 & 54.38 & 35.63 \\
\hline 2019_093 & 52.07446 & 4.21606 & 301.3 & 0.00 & 0.85 & 32.60 & 54.66 & 11.89 \\
\hline 2019_094 & 52.07481 & 4.21539 & 268.5 & 0.00 & 1.85 & 41.38 & 50.15 & 6.63 \\
\hline 2019_095 & 52.07523 & 4.21455 & 233.7 & 0.00 & 5.29 & 51.01 & 40.52 & 3.19 \\
\hline 2019_096 & 52.07561 & 4.21382 & 520.0 & 0.00 & 0.00 & 1.96 & 44.09 & 53.95 \\
\hline 2019_097 & 52.07628 & 4.21247 & 339.8 & 0.00 & 1.94 & 25.51 & 51.22 & 21.33 \\
\hline 2019_098 & 52.07781 & 4.20950 & 675.1 & 0.00 & 0.00 & 0.33 & 25.34 & 74.33 \\
\hline 2019_099 & 52.07999 & 4.20523 & 508.0 & 0.14 & 1.14 & 6.36 & 41.04 & 51.32 \\
\hline
\end{tabular}




\begin{tabular}{|c|c|c|c|c|c|c|c|c|}
\hline StationNr & $\begin{array}{l}\text { Latitude } \\
\text { (WGS84) }\end{array}$ & $\begin{array}{l}\text { Longitude } \\
\text { (WGS84) }\end{array}$ & $\begin{array}{l}\text { Mediaan } \\
\text { ( } \mu \mathrm{m})\end{array}$ & Silt ( $\%)$ & $\begin{array}{l}\text { Zeer fijn } \\
\text { zand }(\%)\end{array}$ & $\begin{array}{c}\text { Fijn zand } \\
(\%)\end{array}$ & $\begin{array}{l}\text { Medium } \\
\text { zand }(\%)\end{array}$ & $\begin{array}{c}\text { Grof zand } \\
(\%)\end{array}$ \\
\hline 2019_100 & 52.08136 & 4.20256 & 386.1 & 0.93 & 0.25 & 16.47 & 53.80 & 28.57 \\
\hline 2019_101 & 52.07948 & 4.22907 & 270.4 & 0.00 & 1.36 & 40.93 & 52.53 & 5.19 \\
\hline 2019_102 & 52.08027 & 4.22754 & 334.0 & 0.00 & 0.01 & 21.64 & 64.88 & 13.47 \\
\hline 2019_103 & 52.08087 & 4.22636 & 286.2 & 0.00 & 0.44 & 35.68 & 57.26 & 6.62 \\
\hline 2019_104 & 52.08125 & 4.22560 & 285.8 & 0.00 & 1.39 & 36.38 & 53.09 & 9.15 \\
\hline 2019_105 & 52.08165 & 4.22482 & 542.4 & 0.00 & 0.00 & 0.24 & 39.97 & 59.79 \\
\hline 2019_106 & 52.08215 & 4.22384 & 205.8 & 0.00 & 9.73 & 58.33 & 29.19 & 2.75 \\
\hline 2019_107 & 52.08300 & 4.22219 & 717.1 & 0.00 & 0.00 & 0.00 & 17.84 & 82.16 \\
\hline 2019_108 & 52.08481 & 4.21866 & 636.3 & 0.00 & 0.00 & 0.26 & 27.86 & 71.88 \\
\hline 2019_109 & 52.08756 & 4.21326 & 284.8 & 0.00 & 2.74 & 36.78 & 47.71 & 12.77 \\
\hline 2019_110 & 52.08860 & 4.21121 & 437.7 & 0.28 & 0.60 & 11.99 & 48.22 & 38.90 \\
\hline 2019_111 & 52.08625 & 4.23867 & 268.2 & 0.00 & 0.99 & 41.65 & 52.81 & 4.55 \\
\hline 2019_112 & 52.08730 & 4.23661 & 241.3 & 0.00 & 2.59 & 51.18 & 44.20 & 2.03 \\
\hline 2019_113 & 52.08790 & 4.23544 & 263.3 & 0.00 & 1.35 & 43.29 & 51.38 & 3.99 \\
\hline 2019_114 & 52.08823 & 4.23482 & 264.3 & 0.00 & 1.36 & 42.87 & 51.88 & 3.89 \\
\hline 2019_115 & 52.08866 & 4.23394 & 190.8 & 0.00 & 10.67 & 67.10 & 22.23 & 0.01 \\
\hline 2019_116 & 52.08914 & 4.23302 & 526.7 & 0.00 & 0.00 & 4.04 & 41.30 & 54.66 \\
\hline 2019_117 & 52.09066 & 4.23006 & 655.6 & 0.07 & 1.11 & 0.11 & 24.65 & 74.07 \\
\hline 2019_118 & 52.09227 & 4.22691 & 456.8 & 0.00 & 0.00 & 8.11 & 50.08 & 41.81 \\
\hline 2019_119 & 52.09388 & 4.22373 & 617.2 & 3.23 & 2.34 & 0.43 & 26.03 & 68.00 \\
\hline 2019_120 & 52.09466 & 4.22223 & 608.4 & 0.00 & 0.00 & 0.17 & 30.87 & 68.97 \\
\hline 2019_121 & 52.00757 & 4.13223 & 279.6 & 0.00 & 0.11 & 36.43 & 60.62 & 2.84 \\
\hline 2019_122 & 52.00747 & 4.13242 & 284.1 & 0.00 & 0.12 & 35.03 & 60.86 & 3.98 \\
\hline 2019_123 & 52.00734 & 4.13267 & 349.1 & 0.00 & 0.00 & 18.59 & 64.98 & 16.42 \\
\hline 2019_124 & 52.00725 & 4.13286 & 349.2 & 0.00 & 0.00 & 15.20 & 71.46 & 13.34 \\
\hline 2019_125 & 52.00715 & 4.13305 & 320.0 & 0.00 & 0.00 & 21.89 & 70.78 & 7.33 \\
\hline 2019_126 & 52.01451 & 4.14148 & 309.2 & 0.00 & 0.10 & 28.57 & 61.43 & 9.90 \\
\hline 2019_127 & 52.01448 & 4.14153 & 347.8 & 0.00 & 0.01 & 19.75 & 62.75 & 17.48 \\
\hline 2019_128 & 52.01440 & 4.14170 & 417.9 & 0.00 & 0.00 & 7.53 & 61.48 & 30.99 \\
\hline 2019_129 & 52.01433 & 4.14184 & 393.3 & 0.00 & 0.00 & 8.78 & 67.41 & 23.82 \\
\hline 2019_130 & 52.01422 & 4.14204 & 323.1 & 0.00 & 0.00 & 21.23 & 70.90 & 7.87 \\
\hline 2019_131 & 52.02157 & 4.15050 & 276.3 & 0.00 & 0.06 & 36.60 & 61.84 & 1.49 \\
\hline 2019_132 & 52.02154 & 4.15057 & 324.8 & 0.00 & 0.00 & 21.11 & 70.05 & 8.85 \\
\hline 2019_133 & 52.02140 & 4.15084 & 324.1 & 0.00 & 0.00 & 21.49 & 69.55 & 8.96 \\
\hline 2019_134 & 52.02130 & 4.15103 & 438.9 & 0.00 & 0.00 & 2.89 & 63.23 & 33.88 \\
\hline 2019_135 & 52.02124 & 4.15115 & 366.0 & 0.00 & 0.00 & 11.57 & 72.14 & 16.28 \\
\hline 2019_136 & 52.02890 & 4.15899 & 326.5 & 0.00 & 0.00 & 20.46 & 70.65 & 8.90 \\
\hline 2019_137 & 52.02887 & 4.15906 & 317.4 & 0.00 & 0.00 & 23.29 & 69.00 & 7.72 \\
\hline 2019_138 & 52.02870 & 4.15940 & 339.9 & 0.00 & 0.00 & 20.50 & 64.67 & 14.83 \\
\hline 2019_139 & 52.02860 & 4.15959 & 328.5 & 0.00 & 0.00 & 19.90 & 71.18 & 8.93 \\
\hline 2019_140 & 52.02851 & 4.15976 & 327.2 & 0.00 & 0.00 & 17.50 & 76.02 & 6.49 \\
\hline 2019_141 & 52.04363 & 4.17585 & 504.7 & 0.00 & 0.00 & 2.21 & 46.84 & 50.95 \\
\hline 2019_142 & 52.04361 & 4.17589 & 524.4 & 0.00 & 0.00 & 0.73 & 43.79 & 55.48 \\
\hline 2019_143 & 52.04356 & 4.17599 & 452.1 & 0.00 & 0.00 & 2.52 & 59.61 & 37.87 \\
\hline 2019_144 & 52.04354 & 4.17604 & 554.4 & 0.00 & 0.00 & 0.67 & 38.50 & 60.83 \\
\hline 2019_145 & 52.04347 & 4.17617 & 535.3 & 0.00 & 0.00 & 0.74 & 41.65 & 57.61 \\
\hline 2019_146 & 52.05032 & 4.18103 & 350.8 & 0.00 & 0.00 & 11.48 & 78.12 & 10.39 \\
\hline 2019_147 & 52.05023 & 4.18121 & 377.1 & 0.00 & 0.00 & 9.77 & 71.32 & 18.91 \\
\hline 2019_148 & 52.05015 & 4.18137 & 377.9 & 0.00 & 0.00 & 9.08 & 72.44 & 18.49 \\
\hline 2019_149 & 52.05006 & 4.18154 & 403.1 & 0.00 & 0.00 & 6.38 & 68.25 & 25.37 \\
\hline 2019_150 & 52.05001 & 4.18164 & 374.8 & 0.00 & 0.00 & 6.99 & 78.03 & 14.97 \\
\hline 2019_151 & 52.05642 & 4.18739 & 341.1 & 0.00 & 0.00 & 11.23 & 82.20 & 6.57 \\
\hline 2019_152 & 52.05638 & 4.18746 & 391.2 & 0.00 & 0.00 & 5.13 & 75.63 & 19.24 \\
\hline
\end{tabular}




\begin{tabular}{|c|c|c|c|c|c|c|c|c|}
\hline StationNr & $\begin{array}{l}\text { Latitude } \\
\text { (WGS84) }\end{array}$ & $\begin{array}{l}\text { Longitude } \\
\text { (WGS84) }\end{array}$ & $\begin{array}{l}\text { Mediaan } \\
\text { ( } \mu \mathrm{m})\end{array}$ & Silt ( $\%)$ & $\begin{array}{l}\text { Zeer fijn } \\
\text { zand }(\%)\end{array}$ & $\begin{array}{c}\text { Fijn zand } \\
(\%)\end{array}$ & $\begin{array}{l}\text { Medium } \\
\text { zand }(\%)\end{array}$ & $\begin{array}{c}\text { Grof zand } \\
(\%)\end{array}$ \\
\hline 2019_153 & 52.05632 & 4.18757 & 421.8 & 0.00 & 0.00 & 7.16 & 60.58 & 32.26 \\
\hline 2019_154 & 52.05630 & 4.18761 & 441.5 & 0.00 & 0.00 & 4.47 & 59.26 & 36.27 \\
\hline 2019_155 & 52.05620 & 4.18781 & 484.3 & 0.00 & 0.00 & 0.88 & 53.20 & 45.91 \\
\hline 2019_156 & 52.06091 & 4.19686 & 389.1 & 0.00 & 0.00 & 7.76 & 70.77 & 21.46 \\
\hline 2019_157 & 52.06078 & 4.19713 & 416.1 & 0.00 & 0.00 & 5.00 & 66.66 & 28.34 \\
\hline 2019_158 & 52.06067 & 4.19734 & 414.3 & 0.00 & 0.00 & 3.17 & 71.39 & 25.45 \\
\hline 2019_159 & 52.06045 & 4.19776 & 333.6 & 0.00 & 0.00 & 15.64 & 76.78 & 7.59 \\
\hline 2019_160 & 52.06015 & 4.19835 & 360.5 & 0.00 & 0.00 & 11.75 & 73.70 & 14.55 \\
\hline 2019_161 & 52.06598 & 4.20978 & 497.2 & 0.00 & 0.00 & 0.66 & 50.05 & 49.29 \\
\hline 2019_162 & 52.06594 & 4.20986 & 479.5 & 0.00 & 0.00 & 1.03 & 54.34 & 44.63 \\
\hline 2019_163 & 52.06581 & 4.21013 & 445.2 & 0.00 & 0.00 & 1.44 & 64.50 & 34.06 \\
\hline 2019_164 & 52.06569 & 4.21036 & 395.1 & 0.00 & 0.00 & 2.78 & 80.02 & 17.21 \\
\hline 2019_165 & 52.06565 & 4.21044 & 368.2 & 0.00 & 0.00 & 8.06 & 78.41 & 13.53 \\
\hline 2019_166 & 52.07225 & 4.22038 & 410.7 & 0.00 & 0.00 & 4.81 & 69.05 & 26.14 \\
\hline 2019_167 & 52.07220 & 4.22047 & 425.3 & 0.00 & 0.00 & 3.63 & 66.29 & 30.09 \\
\hline 2019_168 & 52.07204 & 4.22079 & 404.0 & 0.00 & 0.00 & 3.60 & 74.17 & 22.22 \\
\hline 2019_169 & 52.07195 & 4.22095 & 385.1 & 0.00 & 0.00 & 4.25 & 80.73 & 15.03 \\
\hline 2019_170 & 52.07191 & 4.22104 & 344.8 & 0.00 & 0.00 & 12.62 & 78.23 & 9.15 \\
\hline 2019_171 & 52.07908 & 4.22985 & 333.6 & 0.00 & 0.00 & 15.23 & 77.59 & 7.18 \\
\hline 2019_172 & 52.07902 & 4.22997 & 400.6 & 0.00 & 0.00 & 5.42 & 71.33 & 23.25 \\
\hline 2019_173 & 52.07883 & 4.23034 & 406.1 & 0.00 & 0.00 & 5.54 & 69.15 & 25.31 \\
\hline 2019_174 & 52.07872 & 4.23055 & 372.5 & 0.00 & 0.00 & 7.15 & 78.49 & 14.37 \\
\hline 2019_175 & 52.07868 & 4.23063 & 319.7 & 0.00 & 0.00 & 19.41 & 75.42 & 5.17 \\
\hline 2019_176 & 52.08587 & 4.23943 & 427.0 & 0.00 & 0.00 & 5.50 & 61.90 & 32.60 \\
\hline 2019_177 & 52.08580 & 4.23956 & 369.9 & 0.00 & 0.00 & 8.07 & 77.48 & 14.45 \\
\hline 2019_178 & 52.08560 & 4.23995 & 369.8 & 0.00 & 0.00 & 7.58 & 78.58 & 13.84 \\
\hline 2019_179 & 52.08545 & 4.24023 & 324.2 & 0.00 & 0.00 & 15.06 & 80.79 & 4.14 \\
\hline 2019_180 & 52.08538 & 4.24037 & 319.6 & 0.00 & 0.00 & 16.59 & 79.73 & 3.68 \\
\hline 2019_181 & 52.00690 & 4.13354 & 262.6 & 0.00 & 0.12 & 43.20 & 55.93 & 0.75 \\
\hline 2019_182 & 52.01362 & 4.14323 & 305.2 & 0.00 & 0.06 & 28.14 & 64.78 & 7.02 \\
\hline 2019_183 & 52.02094 & 4.15173 & 298.2 & 0.00 & 0.00 & 27.44 & 69.34 & 3.21 \\
\hline 2019_184 & 52.02814 & 4.16048 & 296.5 & 0.00 & 0.00 & 29.54 & 66.22 & 4.23 \\
\hline 2019_185 & 52.04170 & 4.17963 & 375.9 & 0.00 & 0.00 & 9.78 & 71.60 & 18.62 \\
\hline 2019_186 & 52.04713 & 4.18728 & 379.7 & 0.00 & 0.00 & 14.51 & 61.42 & 24.07 \\
\hline 2019_187 & 52.05281 & 4.19444 & 385.0 & 0.00 & 0.00 & 15.49 & 58.03 & 26.48 \\
\hline 2019_188 & 52.05825 & 4.20207 & 322.0 & 0.00 & 2.52 & 29.07 & 49.02 & 19.38 \\
\hline 2019_189 & 52.06479 & 4.21213 & 407.8 & 0.00 & 0.00 & 4.51 & 70.63 & 24.85 \\
\hline 2019_190 & 52.07148 & 4.22187 & 332.0 & 0.00 & 0.00 & 18.61 & 72.03 & 9.35 \\
\hline 2019_191 & 52.07812 & 4.23173 & 373.8 & 0.00 & 0.00 & 9.33 & 73.32 & 17.35 \\
\hline 2019_192 & 52.08495 & 4.24121 & 318.4 & 0.00 & 0.00 & 20.07 & 74.67 & 5.26 \\
\hline 2019_196 & 52.05910 & 4.20041 & 356.9 & 0.00 & 0.00 & 13.22 & 72.21 & 14.57 \\
\hline 2019_197 & 52.05923 & 4.20016 & 358.6 & 0.00 & 0.00 & 14.55 & 68.84 & 16.61 \\
\hline 2019_198 & 52.05933 & 4.19996 & 361.4 & 0.00 & 0.00 & 13.94 & 69.01 & 17.05 \\
\hline 2019_199 & 52.05945 & 4.19973 & 378.0 & 0.00 & 0.00 & 14.38 & 62.15 & 23.47 \\
\hline 2019_200 & 52.05957 & 4.19948 & 344.0 & 0.00 & 0.00 & 15.83 & 72.34 & 11.83 \\
\hline 2019_201 & 52.05346 & 4.19318 & 292.6 & 3.90 & 4.85 & 29.97 & 47.57 & 13.73 \\
\hline 2019_202 & 52.05342 & 4.19324 & 236.7 & 3.46 & 9.15 & 41.58 & 40.21 & 5.63 \\
\hline 2019_203 & 52.05339 & 4.19332 & 287.1 & 0.01 & 5.73 & 34.23 & 45.95 & 14.07 \\
\hline 2019_204 & 52.05338 & 4.19333 & 401.6 & 0.00 & 0.00 & 13.70 & 55.80 & 30.50 \\
\hline 2019_205 & 52.05337 & 4.19336 & 336.9 & 0.00 & 1.23 & 25.78 & 53.06 & 19.93 \\
\hline 2019_216 & 52.01174 & 4.13546 & 227.5 & 0.00 & 4.50 & 55.22 & 39.15 & 1.13 \\
\hline 2019_217 & 52.01197 & 4.13502 & 210.8 & 0.00 & 4.32 & 65.74 & 29.90 & 0.04 \\
\hline 2019_218 & 52.01325 & 4.13252 & 230.9 & 0.00 & 6.76 & 50.35 & 39.02 & 3.87 \\
\hline
\end{tabular}




\begin{tabular}{|c|c|c|c|c|c|c|c|c|}
\hline StationNr & $\begin{array}{l}\text { Latitude } \\
\text { (WGS84) }\end{array}$ & $\begin{array}{l}\text { Longitude } \\
\text { (WGS84) }\end{array}$ & $\begin{array}{l}\text { Mediaan } \\
\text { ( } \mu \mathrm{m})\end{array}$ & Silt ( $\%)$ & $\begin{array}{l}\text { Zeer fijn } \\
\text { zand }(\%)\end{array}$ & $\begin{array}{c}\text { Fijn zand } \\
(\%)\end{array}$ & $\begin{array}{l}\text { Medium } \\
\text { zand }(\%)\end{array}$ & $\begin{array}{c}\text { Grof zand } \\
(\%)\end{array}$ \\
\hline 2019_219 & 52.01432 & 4.13042 & 193.8 & 0.01 & 15.92 & 54.90 & 27.43 & 1.75 \\
\hline 2019_220 & 52.01492 & 4.12926 & 154.1 & 0.22 & 29.88 & 58.90 & 11.03 & 0.00 \\
\hline 2019_221 & 52.01592 & 4.12730 & 153.1 & 18.69 & 20.96 & 36.95 & 20.86 & 2.65 \\
\hline 2019_222 & 52.01824 & 4.12276 & 187.6 & 0.04 & 20.54 & 49.91 & 25.55 & 3.97 \\
\hline 2019_223 & 52.02103 & 4.11728 & 195.1 & 0.02 & 17.61 & 50.99 & 28.04 & 3.36 \\
\hline 2019_224 & 52.02312 & 4.11318 & 181.5 & 4.08 & 16.27 & 56.45 & 22.85 & 0.35 \\
\hline 2019_225 & 52.01850 & 4.14509 & 334.7 & 2.95 & 1.21 & 25.30 & 48.48 & 22.06 \\
\hline 2019_226 & 52.01922 & 4.14366 & 45.3 & 59.56 & 21.03 & 14.75 & 4.17 & 0.72 \\
\hline 2019_227 & 52.01974 & 4.14267 & 233.5 & 0.00 & 2.00 & 56.04 & 41.36 & 0.60 \\
\hline 2019_228 & 52.02020 & 4.14175 & 212.4 & 0.00 & 6.30 & 60.70 & 32.58 & 0.43 \\
\hline 2019_229 & 52.02151 & 4.13918 & 288.1 & 0.00 & 2.04 & 35.51 & 52.96 & 9.50 \\
\hline 2019_230 & 52.02208 & 4.13805 & 256.6 & 0.00 & 4.37 & 43.32 & 46.74 & 5.57 \\
\hline 2019_231 & 52.02272 & 4.13683 & 214.8 & 0.00 & 11.22 & 51.35 & 34.45 & 2.98 \\
\hline 2019_232 & 52.02392 & 4.13449 & 226.3 & 6.93 & 11.72 & 37.62 & 34.65 & 9.10 \\
\hline 2019_233 & 52.02652 & 4.12942 & 274.7 & 0.02 & 8.30 & 35.44 & 41.99 & 14.26 \\
\hline 2019_234 & 52.02828 & 4.12596 & 395.2 & 0.15 & 6.10 & 19.30 & 40.46 & 34.00 \\
\hline 2019_236 & 52.02616 & 4.15297 & 233.8 & 0.00 & 1.87 & 56.07 & 41.45 & 0.61 \\
\hline 2019_237 & 52.02641 & 4.15246 & 233.0 & 0.00 & 1.89 & 56.51 & 41.09 & 0.51 \\
\hline 2019_238 & 52.02766 & 4.15002 & 219.3 & 0.00 & 5.69 & 57.70 & 35.60 & 1.01 \\
\hline 2019_239 & 52.02871 & 4.14795 & 303.3 & 0.00 & 1.24 & 31.62 & 56.08 & 11.07 \\
\hline 2019_240 & 52.02908 & 4.14724 & 325.9 & 0.00 & 1.23 & 27.35 & 54.80 & 16.62 \\
\hline 2019_241 & 52.02958 & 4.14630 & 565.0 & 0.00 & 0.00 & 2.20 & 36.73 & 61.07 \\
\hline 2019_242 & 52.03032 & 4.14480 & 465.5 & 0.00 & 0.00 & 6.85 & 49.82 & 43.34 \\
\hline 2019_243 & 52.03215 & 4.14119 & 238.4 & 0.00 & 5.06 & 49.43 & 42.67 & 2.82 \\
\hline 2019_244 & 52.03488 & 4.13588 & 315.8 & 0.00 & 1.55 & 29.28 & 54.29 & 14.88 \\
\hline 2019_245 & 52.03276 & 4.16286 & 311.9 & 0.00 & 0.00 & 24.98 & 68.15 & 6.87 \\
\hline 2019_246 & 52.03404 & 4.16036 & 595.1 & 0.00 & 0.00 & 1.01 & 33.10 & 65.89 \\
\hline 2019_247 & 52.03457 & 4.15933 & 285.2 & 0.00 & 0.57 & 35.98 & 57.08 & 6.37 \\
\hline 2019_248 & 52.03499 & 4.15848 & 247.7 & 0.00 & 2.10 & 48.91 & 47.10 & 1.89 \\
\hline 2019_249 & 52.03568 & 4.15715 & 287.2 & 0.00 & 0.56 & 35.21 & 57.96 & 6.26 \\
\hline 2019_250 & 52.03621 & 4.15610 & 350.0 & 0.00 & 0.09 & 20.73 & 60.23 & 18.95 \\
\hline 2019_251 & 52.03673 & 4.15510 & 318.5 & 0.00 & 0.52 & 28.06 & 57.69 & 13.72 \\
\hline 2019_252 & 52.03747 & 4.15366 & 583.7 & 0.00 & 0.00 & 0.10 & 33.77 & 66.13 \\
\hline 2019_253 & 52.04040 & 4.14793 & 305.5 & 0.00 & 2.00 & 32.50 & 48.99 & 16.51 \\
\hline 2019_254 & 52.04160 & 4.14559 & 277.6 & 0.00 & 1.99 & 38.40 & 52.00 & 7.62 \\
\hline 2019_255 & 52.03655 & 4.16688 & 234.9 & 0.00 & 1.74 & 55.75 & 42.01 & 0.49 \\
\hline 2019_256 & 52.03773 & 4.16457 & 534.9 & 0.00 & 0.00 & 1.56 & 41.60 & 56.84 \\
\hline 2019_257 & 52.03822 & 4.16360 & 288.0 & 0.00 & 1.40 & 35.80 & 53.54 & 9.27 \\
\hline 2019_258 & 52.03853 & 4.16301 & 301.7 & 0.00 & 1.07 & 32.41 & 54.80 & 11.73 \\
\hline 2019_259 & 52.03891 & 4.16224 & 213.0 & 0.00 & 8.33 & 56.71 & 33.63 & 1.34 \\
\hline 2019_260 & 52.03911 & 4.16186 & 196.4 & 0.00 & 12.41 & 59.76 & 27.38 & 0.45 \\
\hline 2019_261 & 52.03952 & 4.16107 & 550.2 & 0.09 & 0.51 & 2.53 & 38.20 & 58.67 \\
\hline 2019_262 & 52.04146 & 4.15726 & 429.6 & 0.00 & 0.00 & 10.61 & 52.93 & 36.46 \\
\hline 2019_263 & 52.04416 & 4.15199 & 261.7 & 0.00 & 2.81 & 42.91 & 48.92 & 5.36 \\
\hline 2019_264 & 52.04601 & 4.14839 & 244.8 & 0.00 & 6.99 & 44.68 & 39.99 & 8.34 \\
\hline 2019_265 & 52.04021 & 4.17114 & 250.2 & 0.00 & 1.89 & 48.01 & 47.65 & 2.44 \\
\hline 2019_266 & 52.04116 & 4.16927 & 215.4 & 6.96 & 4.68 & 53.09 & 34.73 & 0.54 \\
\hline 2019_267 & 52.04166 & 4.16829 & 321.1 & 0.00 & 0.09 & 25.31 & 63.19 & 11.41 \\
\hline 2019_268 & 52.04206 & 4.16747 & 288.0 & 0.00 & 0.48 & 34.96 & 58.24 & 6.32 \\
\hline 2019_269 & 52.04247 & 4.16670 & 203.4 & 0.00 & 11.17 & 57.47 & 30.32 & 1.03 \\
\hline 2019_270 & 52.04284 & 4.16598 & 542.0 & 0.00 & 0.00 & 1.73 & 40.53 & 57.74 \\
\hline 2019_271 & 52.04363 & 4.16442 & 318.3 & 3.88 & 0.28 & 24.23 & 59.07 & 12.56 \\
\hline 2019_272 & 52.04507 & 4.16162 & 229.4 & 0.00 & 5.09 & 53.41 & 39.86 & 1.64 \\
\hline
\end{tabular}




\begin{tabular}{|c|c|c|c|c|c|c|c|c|}
\hline StationNr & $\begin{array}{l}\text { Latitude } \\
\text { (WGS84) }\end{array}$ & $\begin{array}{l}\text { Longitude } \\
\text { (WGS84) }\end{array}$ & $\begin{array}{l}\text { Mediaan } \\
\text { ( } \mu \mathrm{m})\end{array}$ & Silt ( $\%)$ & $\begin{array}{l}\text { Zeer fijn } \\
\text { zand }(\%)\end{array}$ & $\begin{array}{c}\text { Fijn zand } \\
(\%)\end{array}$ & $\begin{array}{l}\text { Medium } \\
\text { zand }(\%)\end{array}$ & $\begin{array}{c}\text { Grof zand } \\
(\%)\end{array}$ \\
\hline 2019_273 & 52.04736 & 4.15713 & 214.0 & 0.00 & 8.03 & 56.92 & 34.24 & 0.81 \\
\hline 2019_274 & 52.04859 & 4.15471 & 201.9 & 0.00 & 11.80 & 57.67 & 29.95 & 0.59 \\
\hline 2019_275 & 52.04732 & 4.17779 & 252.1 & 0.00 & 0.89 & 48.09 & 49.78 & 1.24 \\
\hline 2019_276 & 52.04822 & 4.17600 & 331.8 & 0.00 & 0.16 & 24.64 & 59.58 & 15.62 \\
\hline 2019_277 & 52.04881 & 4.17486 & 332.9 & 0.00 & 0.00 & 21.22 & 66.63 & 12.14 \\
\hline 2019_278 & 52.04918 & 4.17413 & 328.2 & 0.00 & 0.23 & 25.54 & 59.27 & 14.96 \\
\hline 2019_279 & 52.04947 & 4.17358 & 259.6 & 0.00 & 1.30 & 44.65 & 51.34 & 2.71 \\
\hline 2019_280 & 52.04978 & 4.17295 & 254.8 & 0.00 & 3.58 & 44.69 & 46.74 & 4.99 \\
\hline 2019_281 & 52.05050 & 4.17155 & 200.3 & 5.36 & 9.76 & 54.67 & 29.66 & 0.56 \\
\hline 2019_282 & 52.05156 & 4.16949 & 416.2 & 0.00 & 0.84 & 17.12 & 45.38 & 36.65 \\
\hline 2019_283 & 52.05277 & 4.16711 & 212.2 & 0.00 & 5.92 & 61.62 & 32.11 & 0.36 \\
\hline 2019_284 & 52.05411 & 4.16447 & 259.4 & 0.00 & 3.76 & 43.09 & 44.73 & 8.43 \\
\hline 2019_285 & 52.05370 & 4.18357 & 422.5 & 0.00 & 0.00 & 5.73 & 63.01 & 31.26 \\
\hline 2019_286 & 52.05456 & 4.18188 & 535.4 & 0.00 & 0.00 & 1.64 & 41.52 & 56.85 \\
\hline 2019_287 & 52.05492 & 4.18119 & 403.6 & 0.00 & 0.00 & 4.01 & 73.33 & 22.67 \\
\hline 2019_288 & 52.05602 & 4.17908 & 389.3 & 0.00 & 0.00 & 10.23 & 65.89 & 23.89 \\
\hline 2019_289 & 52.05693 & 4.17724 & 438.3 & 0.00 & 0.00 & 4.50 & 60.14 & 35.36 \\
\hline 2019_290 & 52.05739 & 4.17636 & 435.9 & 0.00 & 0.00 & 3.39 & 63.17 & 33.44 \\
\hline 2019_291 & 52.05777 & 4.17559 & 385.4 & 0.00 & 0.00 & 9.95 & 67.75 & 22.30 \\
\hline 2019_292 & 52.05821 & 4.17477 & 410.1 & 0.00 & 0.00 & 10.38 & 58.68 & 30.93 \\
\hline 2019_293 & 52.05896 & 4.17326 & 558.0 & 1.20 & 1.79 & 5.35 & 32.92 & 58.75 \\
\hline 2019_294 & 52.05934 & 4.17251 & 605.3 & 0.00 & 0.00 & 0.41 & 31.95 & 67.64 \\
\hline 2019_296 & 52.06029 & 4.18895 & 303.9 & 0.00 & 0.19 & 30.18 & 60.59 & 9.04 \\
\hline 2019_297 & 52.06060 & 4.18831 & 227.9 & 0.00 & 2.12 & 59.13 & 38.55 & 0.20 \\
\hline 2019_298 & 52.06093 & 4.18768 & 267.4 & 0.00 & 0.88 & 41.91 & 53.68 & 3.53 \\
\hline 2019_299 & 52.06200 & 4.18563 & 326.0 & 0.00 & 0.00 & 22.93 & 66.23 & 10.85 \\
\hline 2019_300 & 52.06281 & 4.18400 & 385.6 & 0.00 & 0.00 & 7.94 & 71.72 & 20.34 \\
\hline 2019_301 & 52.06344 & 4.18277 & 386.7 & 0.00 & 0.00 & 8.11 & 70.89 & 21.00 \\
\hline 2019_302 & 52.06399 & 4.18170 & 393.3 & 0.00 & 0.00 & 8.59 & 67.39 & 24.02 \\
\hline 2019_303 & 52.06460 & 4.18050 & 327.8 & 0.00 & 0.00 & 20.01 & 70.91 & 9.08 \\
\hline 2019_304 & 52.06495 & 4.17984 & 368.4 & 0.00 & 0.17 & 20.86 & 52.39 & 26.57 \\
\hline 2019_305 & 52.06393 & 4.20238 & 310.2 & 0.00 & 0.22 & 28.82 & 60.46 & 10.51 \\
\hline 2019_306 & 52.06461 & 4.20104 & 54.8 & 54.27 & 19.73 & 13.32 & 10.46 & 2.46 \\
\hline 2019_307 & 52.06499 & 4.20030 & 256.1 & 0.00 & 1.54 & 45.87 & 50.05 & 2.53 \\
\hline 2019_308 & 52.06542 & 4.19946 & 213.7 & 0.00 & 8.38 & 56.52 & 34.21 & 0.89 \\
\hline 2019_309 & 52.06603 & 4.19827 & 175.8 & 0.00 & 16.83 & 66.91 & 16.25 & 0.00 \\
\hline 2019_310 & 52.06651 & 4.19734 & 170.4 & 5.89 & 16.31 & 62.62 & 15.18 & 0.00 \\
\hline 2019_311 & 52.06725 & 4.19589 & 171.3 & 13.46 & 15.65 & 49.32 & 21.58 & 0.02 \\
\hline 2019_312 & 52.06840 & 4.19364 & 210.5 & 3.55 & 5.71 & 58.45 & 31.94 & 0.35 \\
\hline 2019_313 & 52.07009 & 4.19031 & 214.9 & 0.00 & 7.81 & 56.69 & 34.40 & 1.11 \\
\hline 2019_314 & 52.07109 & 4.18837 & 224.4 & 9.10 & 4.67 & 45.65 & 38.28 & 2.30 \\
\hline 2019_315 & 52.06967 & 4.21402 & 255.5 & 0.00 & 1.73 & 45.96 & 49.39 & 2.92 \\
\hline 2019_316 & 52.07060 & 4.21216 & 560.2 & 6.66 & 3.35 & 0.60 & 29.39 & 60.05 \\
\hline 2019_317 & 52.07117 & 4.21104 & 288.6 & 0.00 & 0.90 & 35.44 & 55.35 & 8.30 \\
\hline 2019_318 & 52.07159 & 4.21025 & 295.3 & 0.00 & 0.85 & 33.89 & 55.33 & 9.93 \\
\hline 2019_319 & 52.07203 & 4.20936 & 196.5 & 0.00 & 9.50 & 65.29 & 25.19 & 0.03 \\
\hline 2019_320 & 52.07245 & 4.20856 & 169.6 & 7.66 & 18.17 & 55.24 & 18.79 & 0.15 \\
\hline 2019_321 & 52.07309 & 4.20729 & 192.7 & 3.39 & 17.69 & 46.57 & 27.28 & 5.08 \\
\hline 2019_322 & 52.07460 & 4.20435 & 209.3 & 0.00 & 13.43 & 50.57 & 32.91 & 3.10 \\
\hline 2019_323 & 52.07650 & 4.20063 & 210.4 & 0.00 & 10.76 & 54.30 & 33.13 & 1.81 \\
\hline 2019_324 & 52.07800 & 4.19770 & 256.6 & 0.01 & 7.77 & 40.28 & 43.08 & 8.88 \\
\hline 2019_325 & 52.07597 & 4.22452 & 312.8 & 0.00 & 0.00 & 24.63 & 68.37 & 7.01 \\
\hline 2019_326 & 52.07675 & 4.22301 & 273.3 & 0.00 & 0.17 & 39.01 & 58.49 & 2.34 \\
\hline
\end{tabular}




\begin{tabular}{|c|c|c|c|c|c|c|c|c|}
\hline StationNr & $\begin{array}{l}\text { Latitude } \\
\text { (WGS84) }\end{array}$ & $\begin{array}{l}\text { Longitude } \\
\text { (wGS84) }\end{array}$ & $\begin{array}{c}\text { Mediaan } \\
\text { ( } \mu \mathrm{m})\end{array}$ & Silt (\%) & $\begin{array}{l}\text { Zeer fijn } \\
\text { zand }(\%)\end{array}$ & $\begin{array}{c}\text { Fijn zand } \\
(\%)\end{array}$ & $\begin{array}{l}\text { Medium } \\
\text { zand }(\%)\end{array}$ & $\begin{array}{c}\text { Grof zand } \\
(\%)\end{array}$ \\
\hline 2019_327 & 52.07721 & 4.22207 & 284.5 & 0.00 & 0.55 & 36.16 & 57.16 & 6.14 \\
\hline 2019_328 & 52.07785 & 4.22083 & 215.5 & 0.00 & 4.07 & 63.15 & 32.65 & 0.13 \\
\hline 2019_329 & 52.07830 & 4.21997 & 197.4 & 0.00 & 7.82 & 68.00 & 24.17 & 0.01 \\
\hline 2019_331 & 52.07978 & 4.21707 & 425.5 & 0.00 & 0.06 & 11.67 & 52.49 & 35.77 \\
\hline 2019_332 & 52.08161 & 4.21343 & 279.1 & 0.00 & 1.93 & 37.98 & 52.17 & 7.92 \\
\hline 2019_333 & 52.08412 & 4.20857 & 409.0 & 0.56 & 2.03 & 17.51 & 44.26 & 35.65 \\
\hline 2019_334 & 52.08555 & 4.20577 & 261.0 & 0.00 & 2.73 & 43.22 & 48.77 & 5.28 \\
\hline 2019_338 & 52.08473 & 4.23022 & 243.9 & 0.00 & 2.43 & 50.16 & 45.27 & 2.13 \\
\hline 2019_339 & 52.08509 & 4.22953 & 188.4 & 0.00 & 11.20 & 68.17 & 20.62 & 0.01 \\
\hline 2019_340 & 52.08546 & 4.22879 & 184.1 & 0.00 & 13.07 & 67.68 & 19.25 & 0.00 \\
\hline 2019_341 & 52.08667 & 4.22642 & 608.8 & 0.00 & 0.00 & 0.08 & 30.10 & 69.83 \\
\hline 2019_342 & 52.08845 & 4.22292 & 546.8 & 0.15 & 1.39 & 3.49 & 37.14 & 57.85 \\
\hline 2019_343 & 52.09073 & 4.21848 & 271.2 & 2.62 & 2.60 & 37.83 & 48.26 & 8.69 \\
\hline 2019_344 & 52.09130 & 4.21739 & 283.7 & 4.11 & 5.47 & 32.21 & 41.87 & 16.34 \\
\hline 2019_003 & 52.00852 & 4.13033 & 216.8 & 0.00 & 3.55 & 63.27 & 33.06 & 0.12 \\
\hline
\end{tabular}




\section{Bijlage 6 Verspreiding van enkele bodemdiersoorten uit de schaaf}

In onderstaande figuren zijn de verspreidingskaarten gepresenteerd van een aantal kenmerkende bodemdiersoorten uit de bodemschaaf over de jaren 2010, 2012, 2013, 2015, 2017 en 2019. De figuren geven een beeld van de ruimtelijke en temporele ontwikkeling van de betreffende soorten.

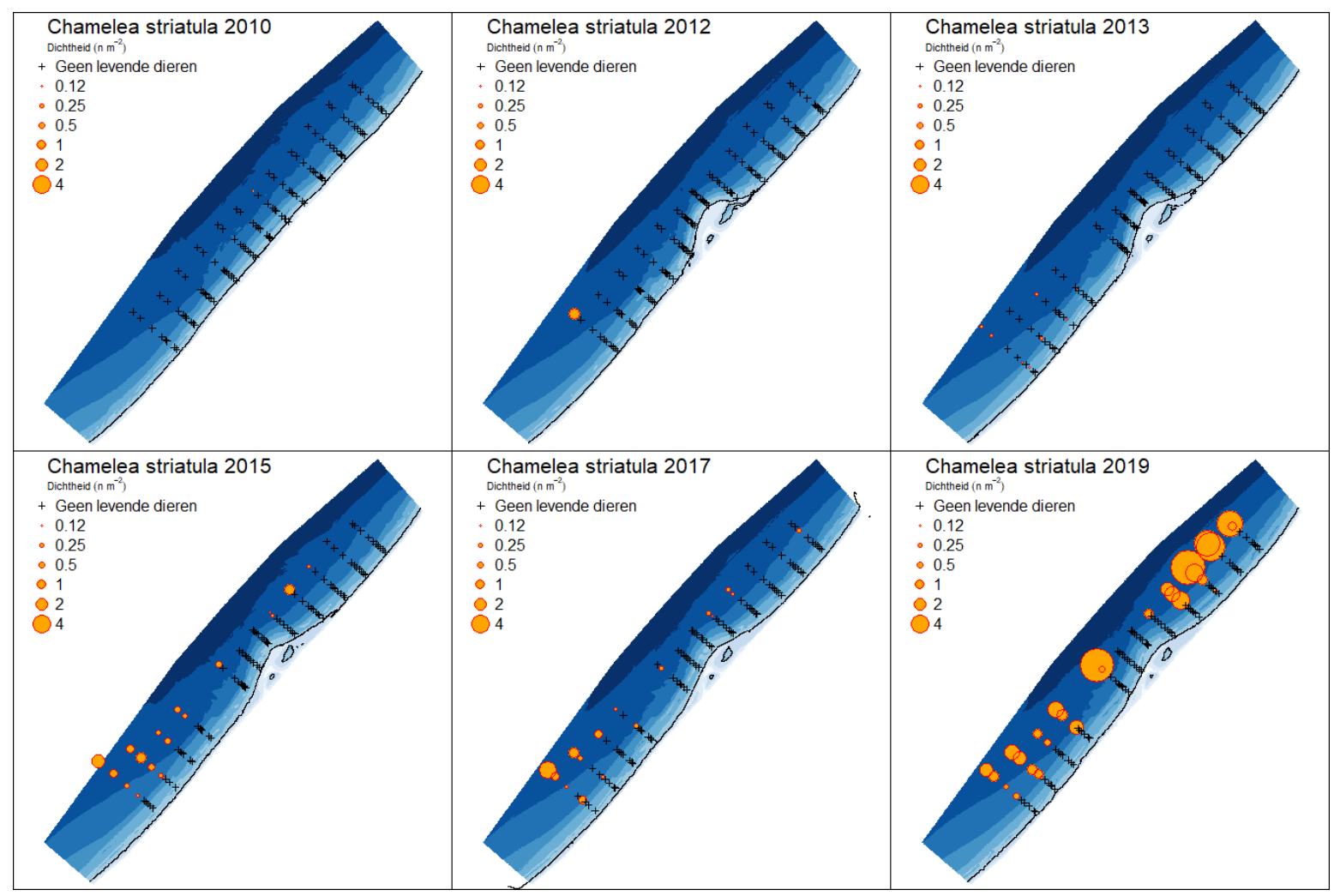

Figuur 63: Verspreidingskaarten Chamelea striulata in de bodemschaaf over de jaren 2010 tot en met 2019. 


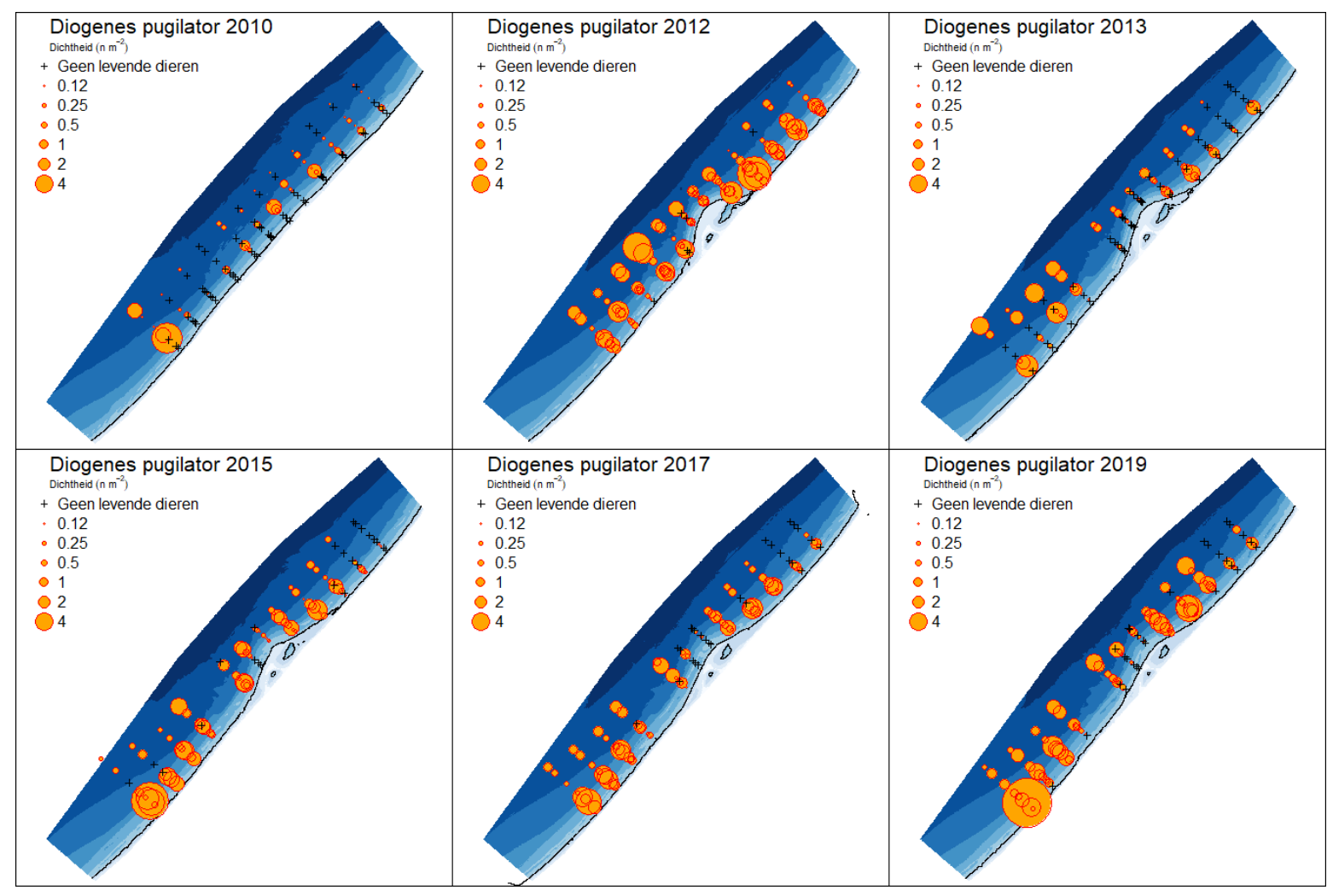

Figuur 64: Verspreidingskaarten Diogenes pugulator in de bodemschaaf over de jaren 2010 tot en met 2019.

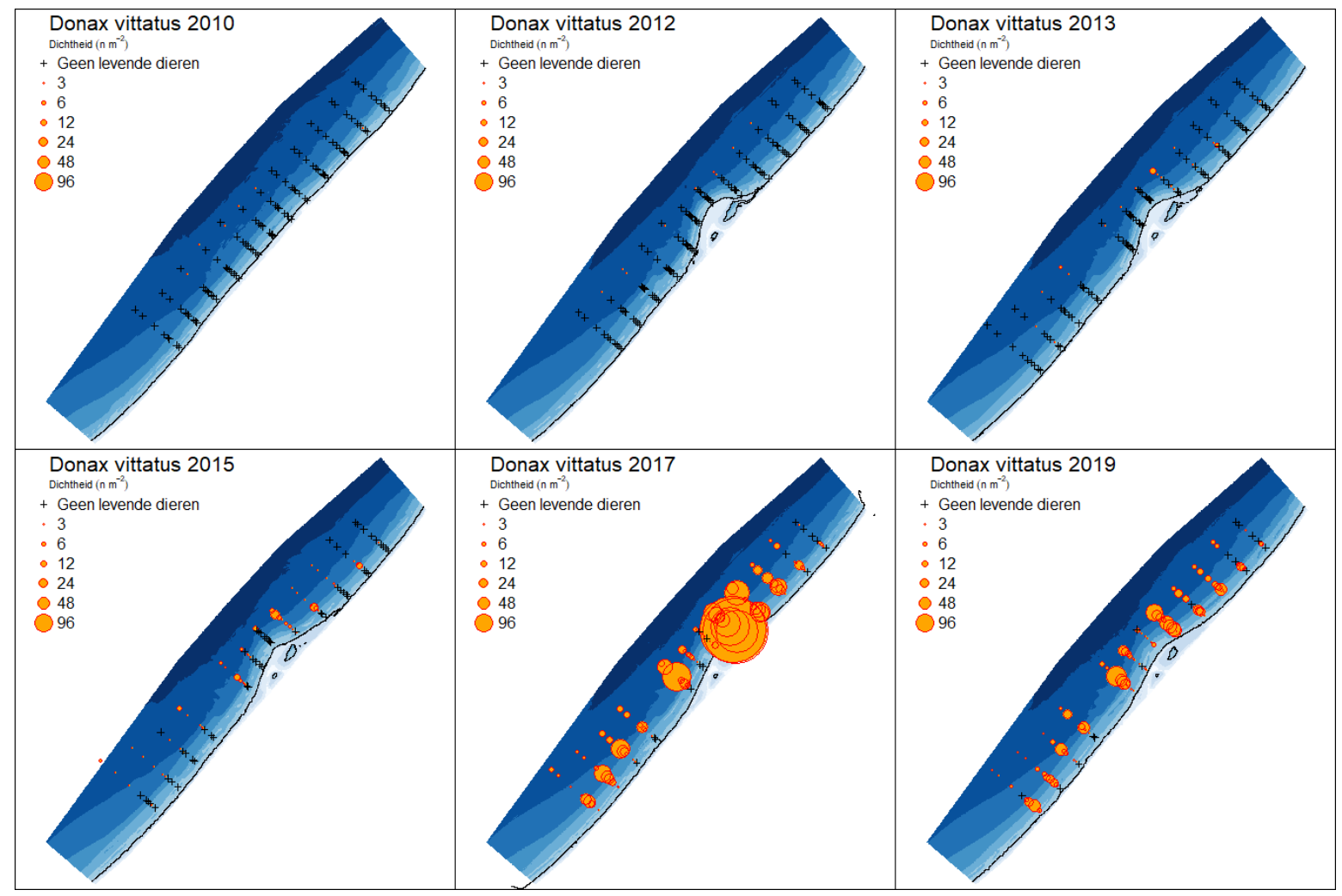

Figuur 65: Verspreidingskaarten Donax vittatus in de bodemschaaf over de jaren 2010 tot en met 2019. 


$$
\begin{aligned}
& \text { Iin } \\
& \text { sis }
\end{aligned}
$$




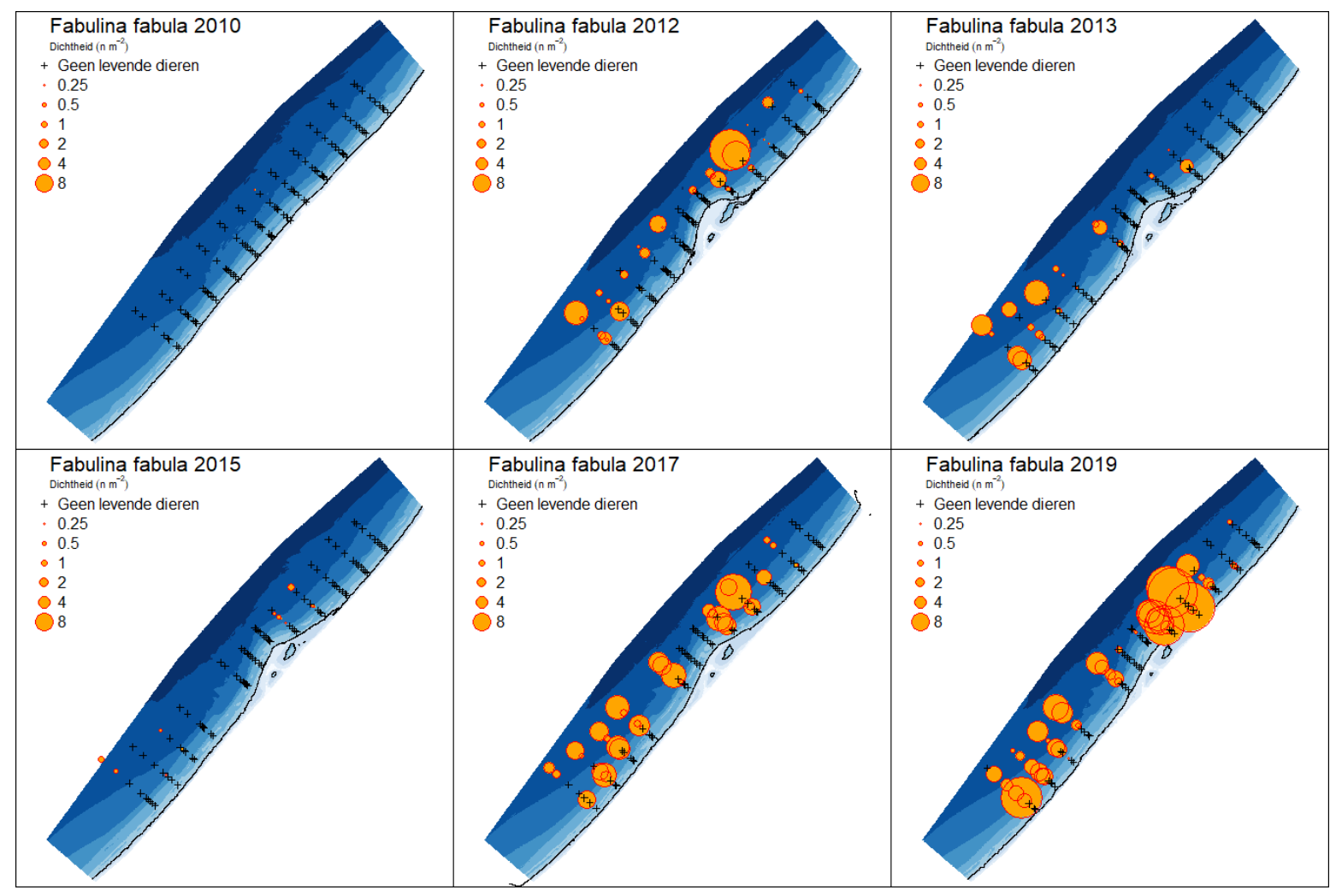

Figuur 68: Verspreidingskaarten Fabulina fabula in de bodemschaaf over de jaren 2010 tot en met 2019.

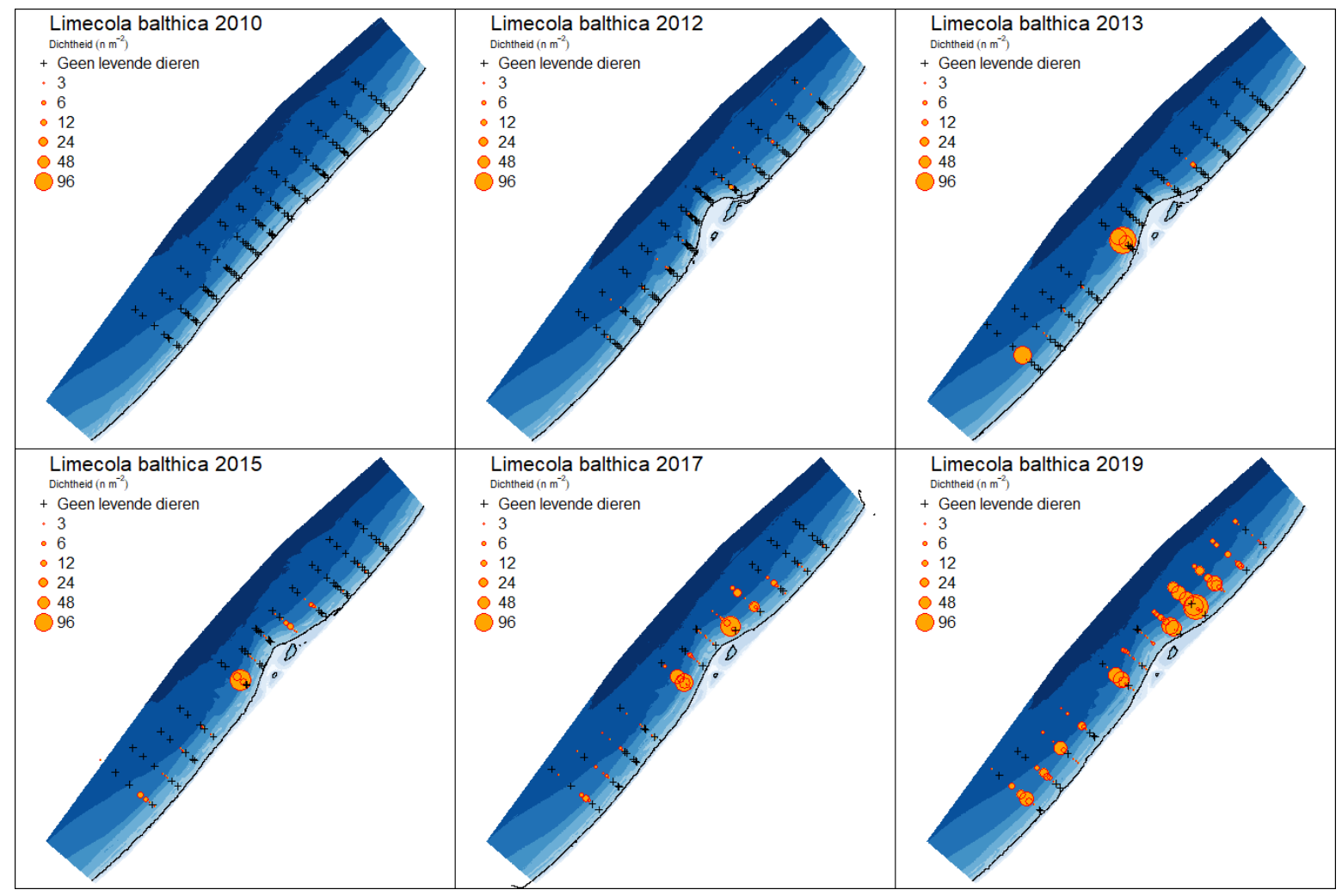

Figuur 69: Verspreidingskaarten Limecola balthica in de bodemschaaf over de jaren 2010 tot en met 2019. 


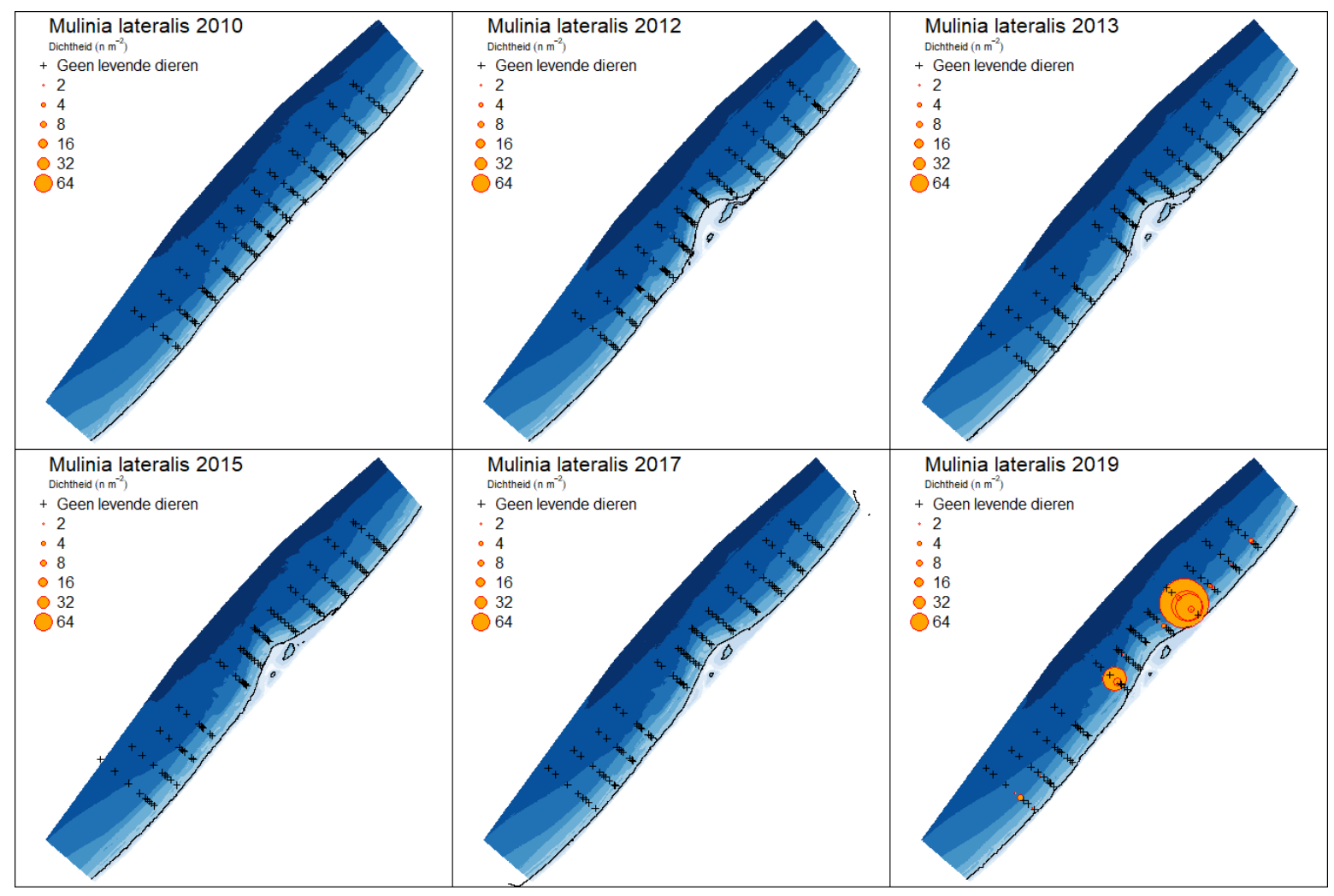

Figuur 70: Verspreidingskaarten Mulinia lateralis in de bodemschaaf over de jaren 2010 tot en met 2019.

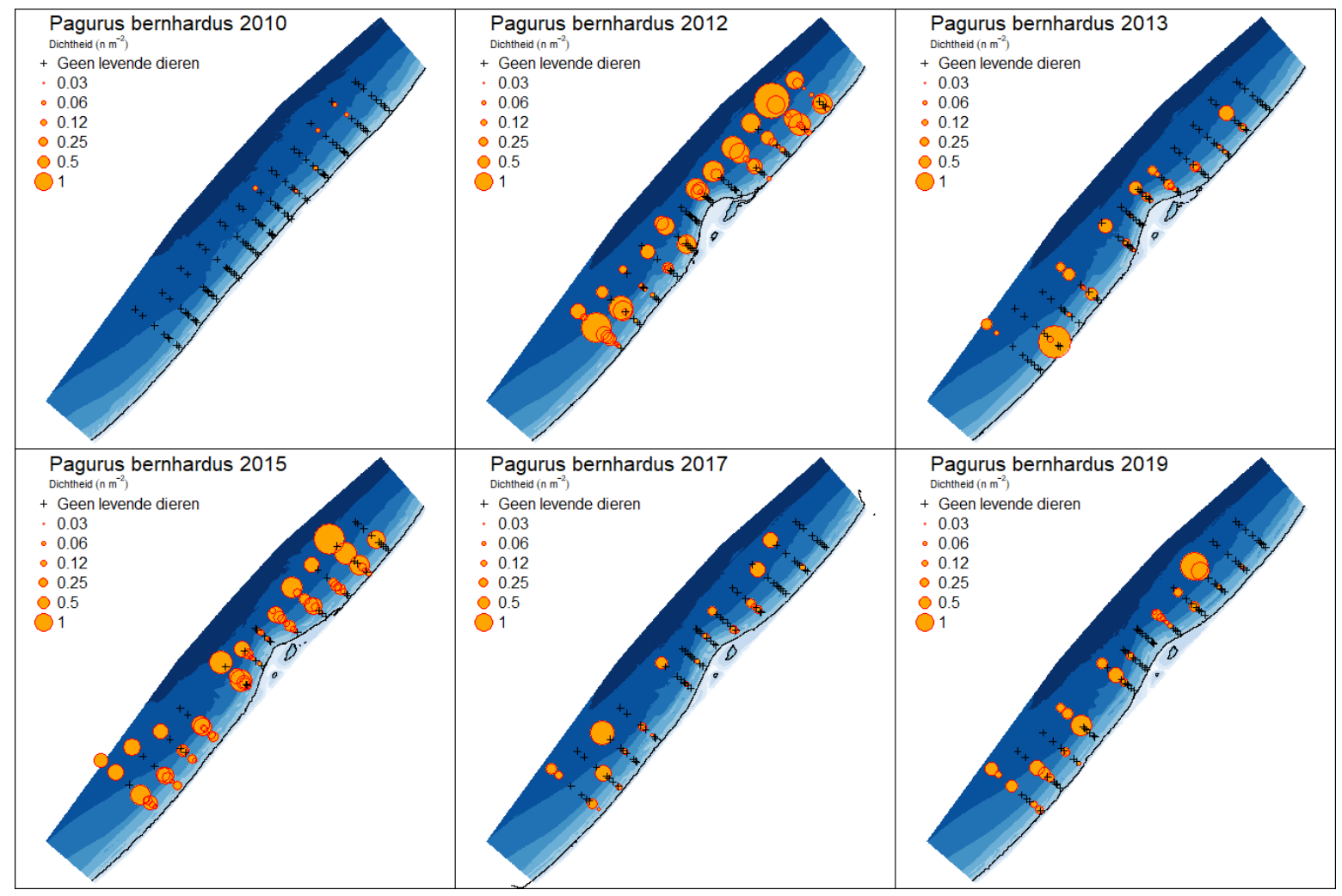

Figuur 71: Verspreidingskaarten Pagurus bernhardus in de bodemschaaf over de jaren 2010 tot en met 2019. 


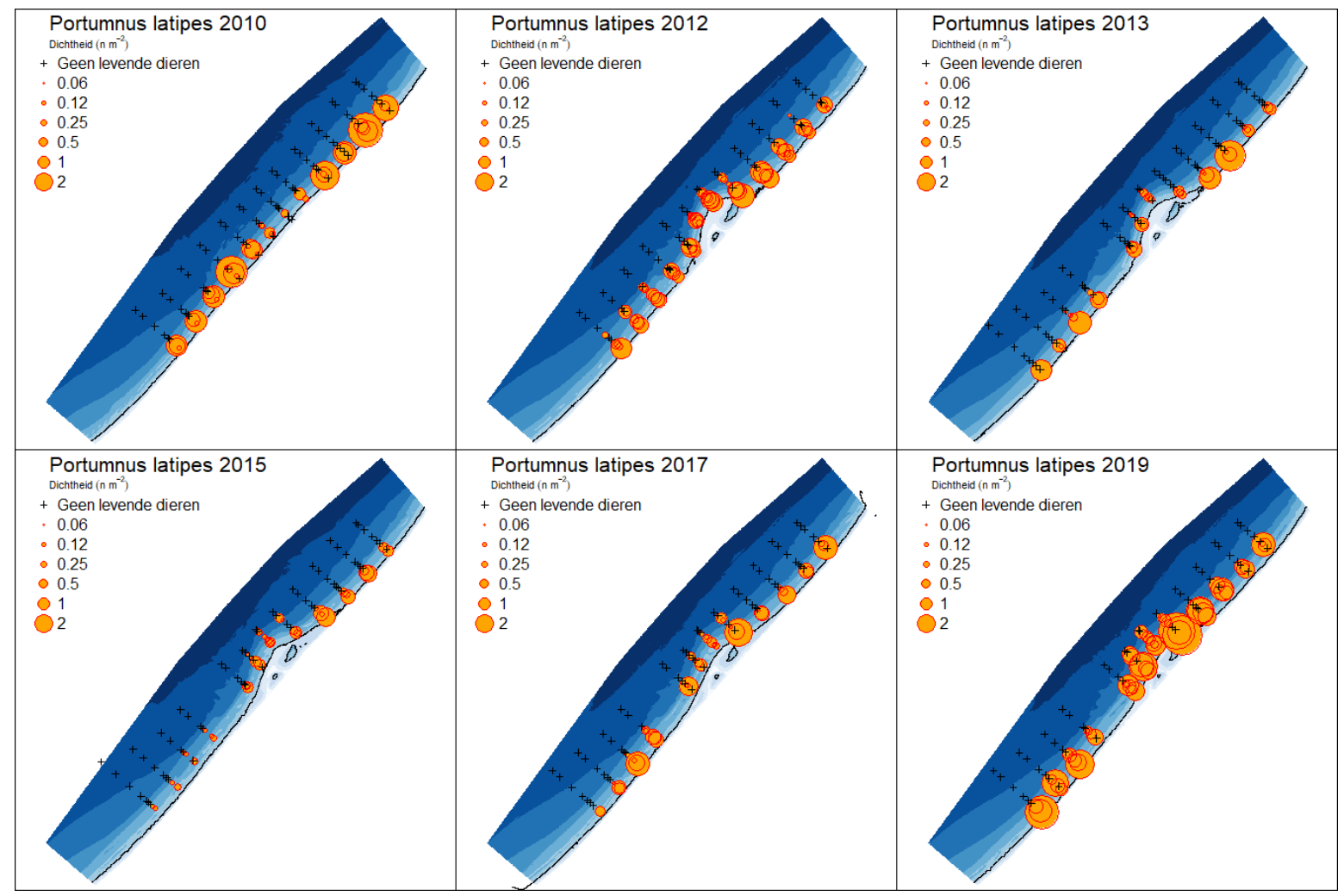

Figuur 72: Verspreidingskaarten Portumnus latipes in de bodemschaaf over de jaren 2010 tot en met 2019.

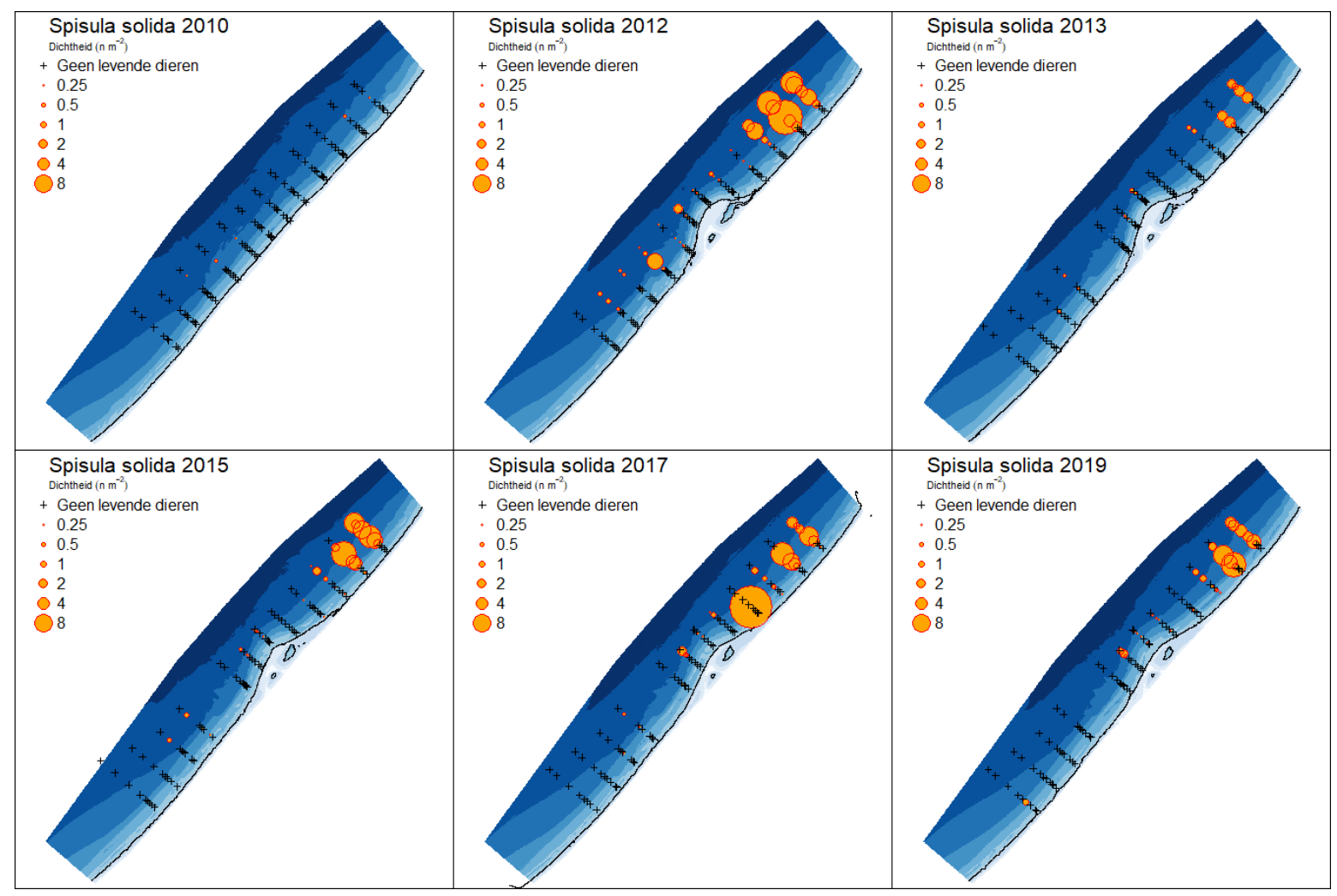

Figuur 73: Verspreidingskaarten Spisula solida in de bodemschaaf over de jaren 2010 tot en met 2019. 


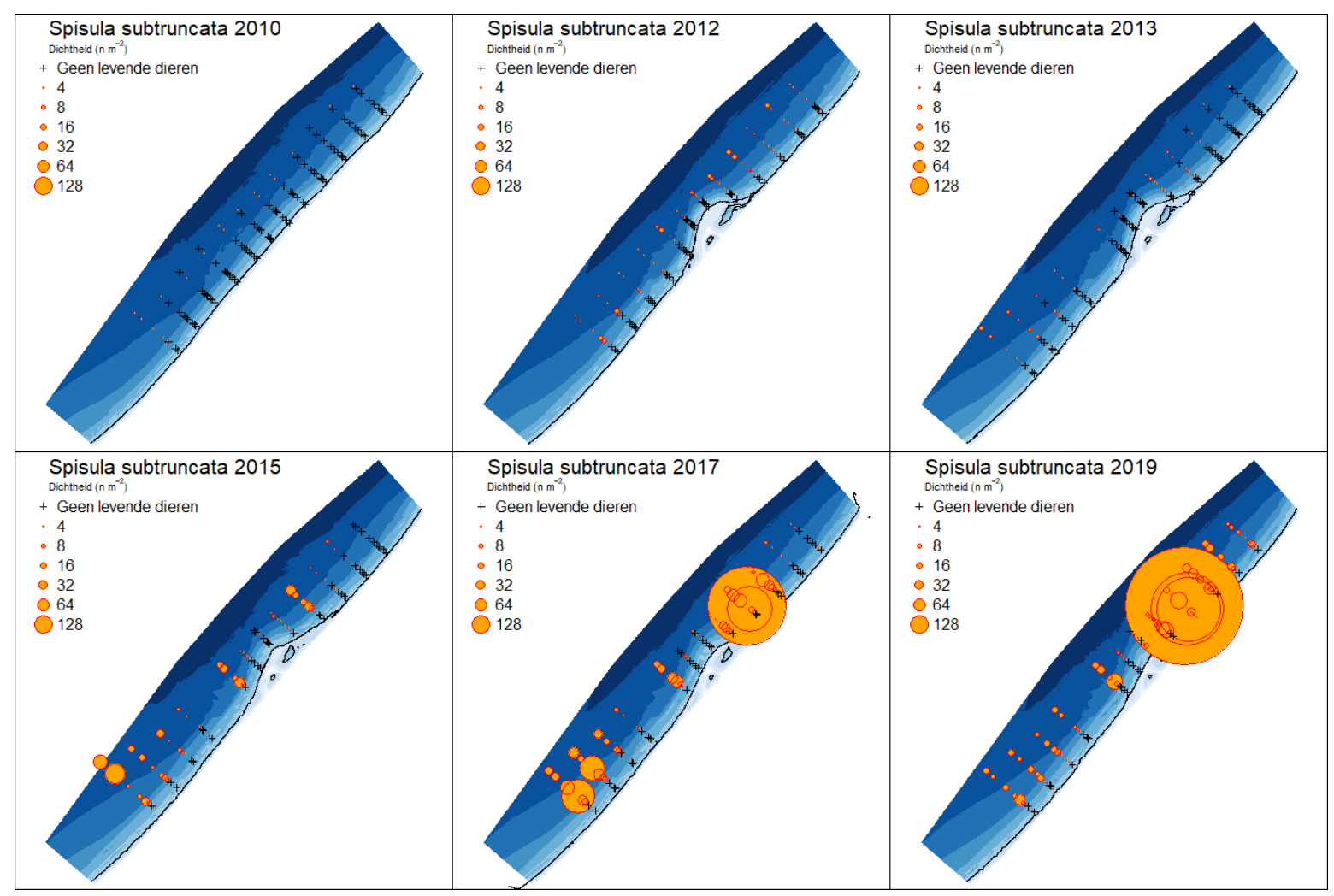

Figuur 74: Verspreidingskaarten Spisula subtruncata in de bodemschaaf over de jaren 2010 tot en met 2019. 


\section{Bijlage 7 Clusteranalyse bodemschaaf voorgaande jaren}
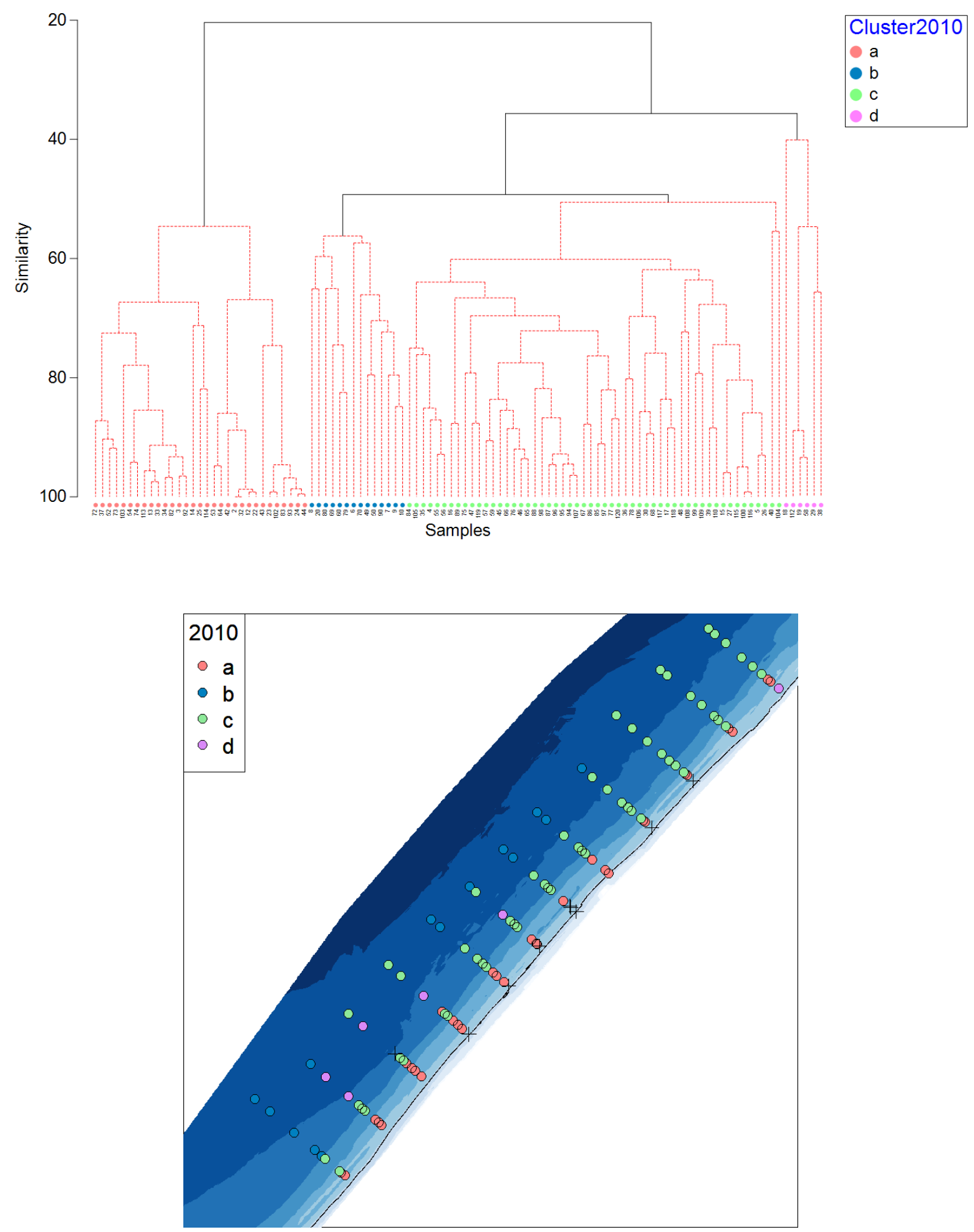

Figuur 75: Clusteranalyse data bodemschaaf 2010. Bovenste figuur het dendrogram. Zwarte lijnen van het dendrogram geven de significante $(p<0.05)$ clusters weer. De markers geven de verschillende clusters. Onderste plot: de ruimtelijke verdeling van de clusters over het gebied. 

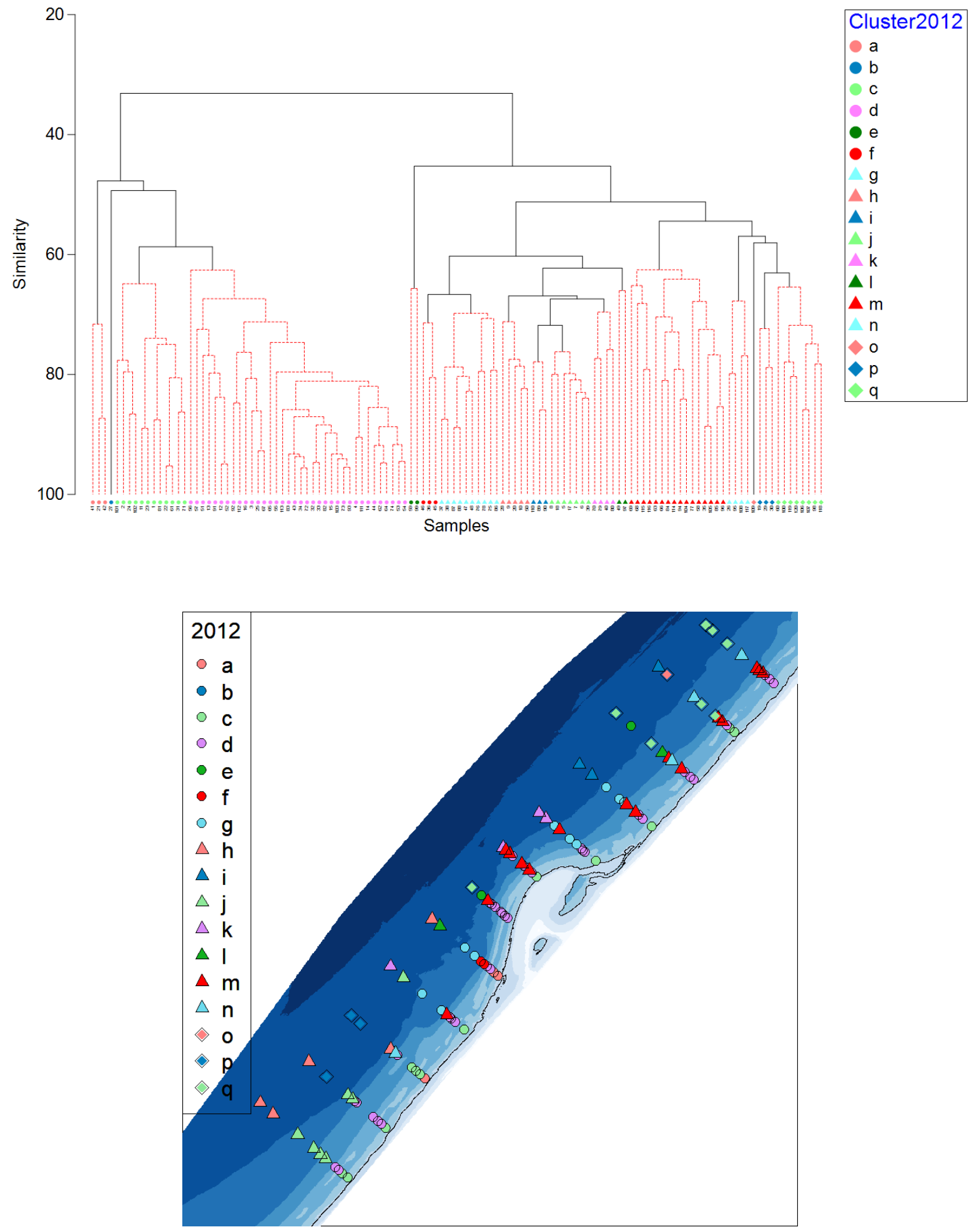

Figuur 76: Clusteranalyse data bodemschaaf 2012. Bovenste figuur het dendrogram. Zwarte lijnen van het dendrogram geven de significante $(p<0.05)$ clusters weer. De markers geven de verschillende clusters. Onderste plot: de ruimtelijke verdeling van de clusters over het gebied. 

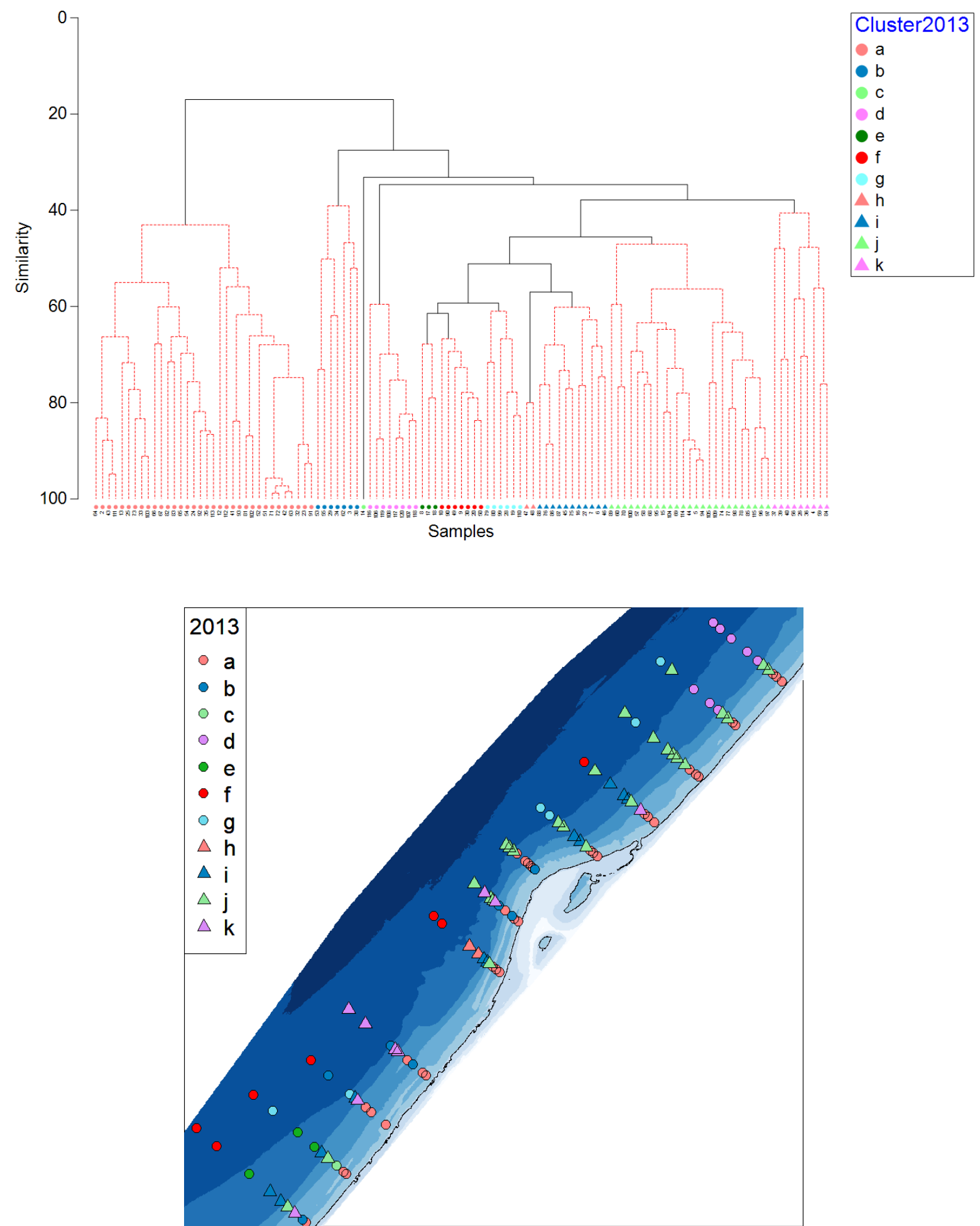

Figuur 77: Clusteranalyse data bodemschaaf 2013. Bovenste figuur het dendrogram. Zwarte lijnen van het dendrogram geven de significante $(p<0.05)$ clusters weer. De markers geven de verschillende clusters. Onderste plot: de ruimtelijke verdeling van de clusters over het gebied. 

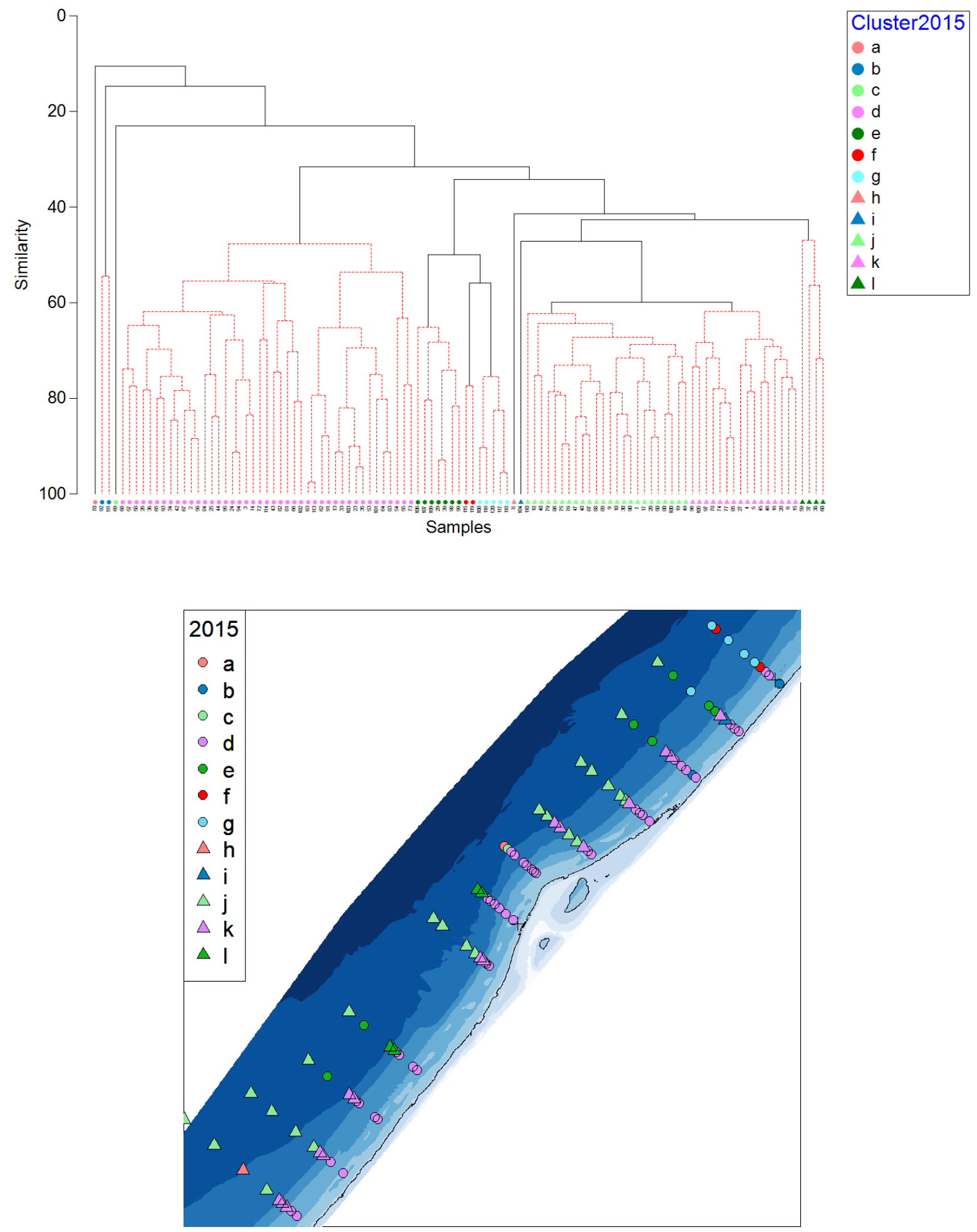

Figuur 78: Clusteranalyse data bodemschaaf 2015. Bovenste figuur het dendrogram. Zwarte lijnen van het dendrogram geven de significante $(p<0.05)$ clusters weer. De markers geven de verschillende clusters. Onderste plot: de ruimtelijke verdeling van de clusters over het gebied. 

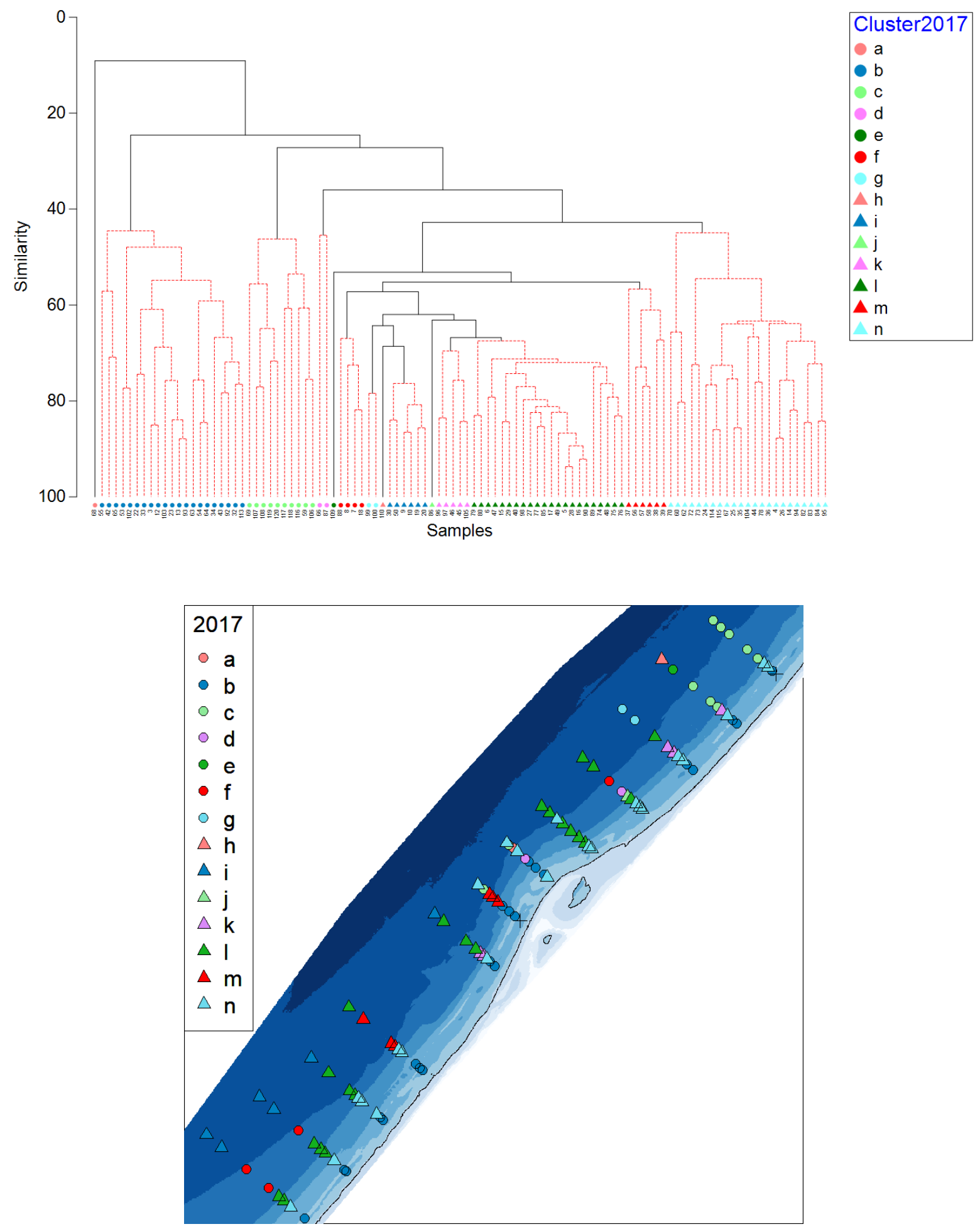

Figuur 79: Clusteranalyse data bodemschaaf 2017. Bovenste figuur het dendrogram. Zwarte lijnen van het dendrogram geven de significante $(p<0.05)$ clusters weer. De markers geven de verschillende clusters. Onderste plot: de ruimtelijke verdeling van de clusters over het gebied. 


\section{Bijlage 8 Verspreiding van enkele bodemdiersoorten uit de Van Veen}

In onderstaande figuren zijn de verspreidingskaarten gepresenteerd van een aantal kenmerkende bodemdiersoorten uit de Van Veen monsters over de jaren 2010, 2012, 2013, 2015, 2017 en 2019. De figuren geven een beeld van de ruimtelijke en temporele ontwikkeling van de betreffende soorten.

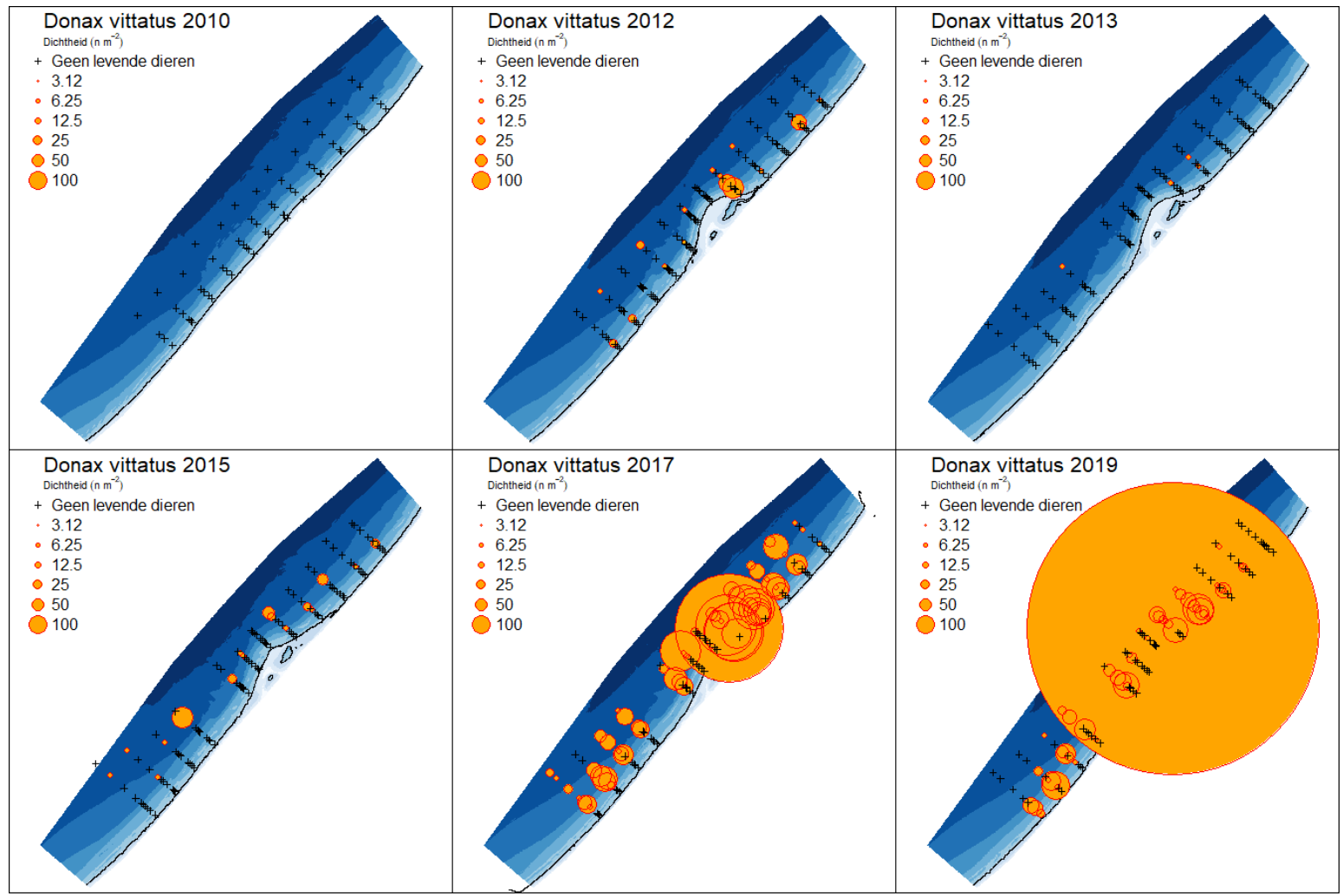

Figuur 80: Verspreidingskaarten Donax vittatus in de Van Veen bemonstering over de jaren 2010 tot en met 2019. 


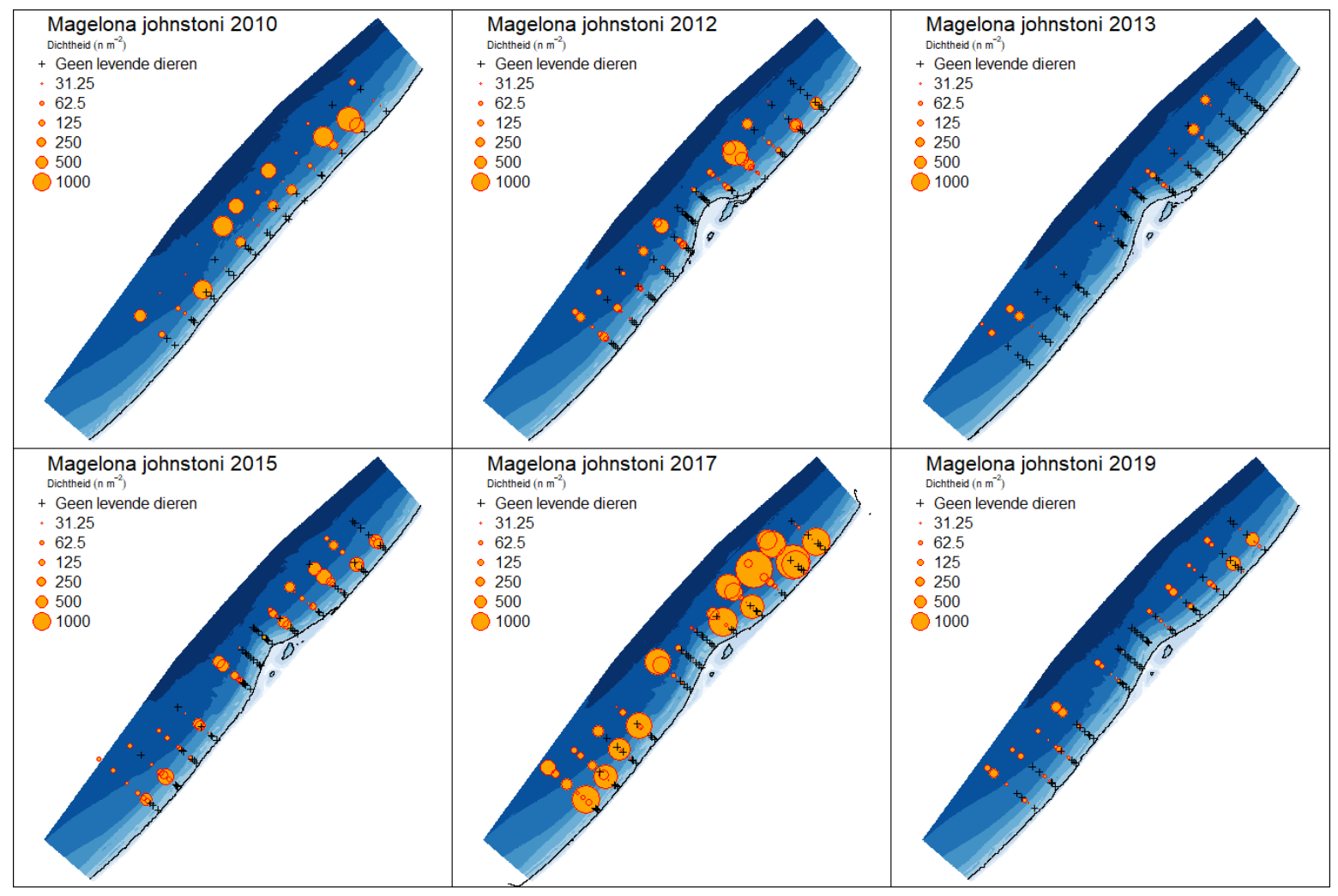

Figuur 81: Verspreidingskaarten Magelona johnstoni in de Van Veen bemonstering over de jaren 2010 tot en met 2019.

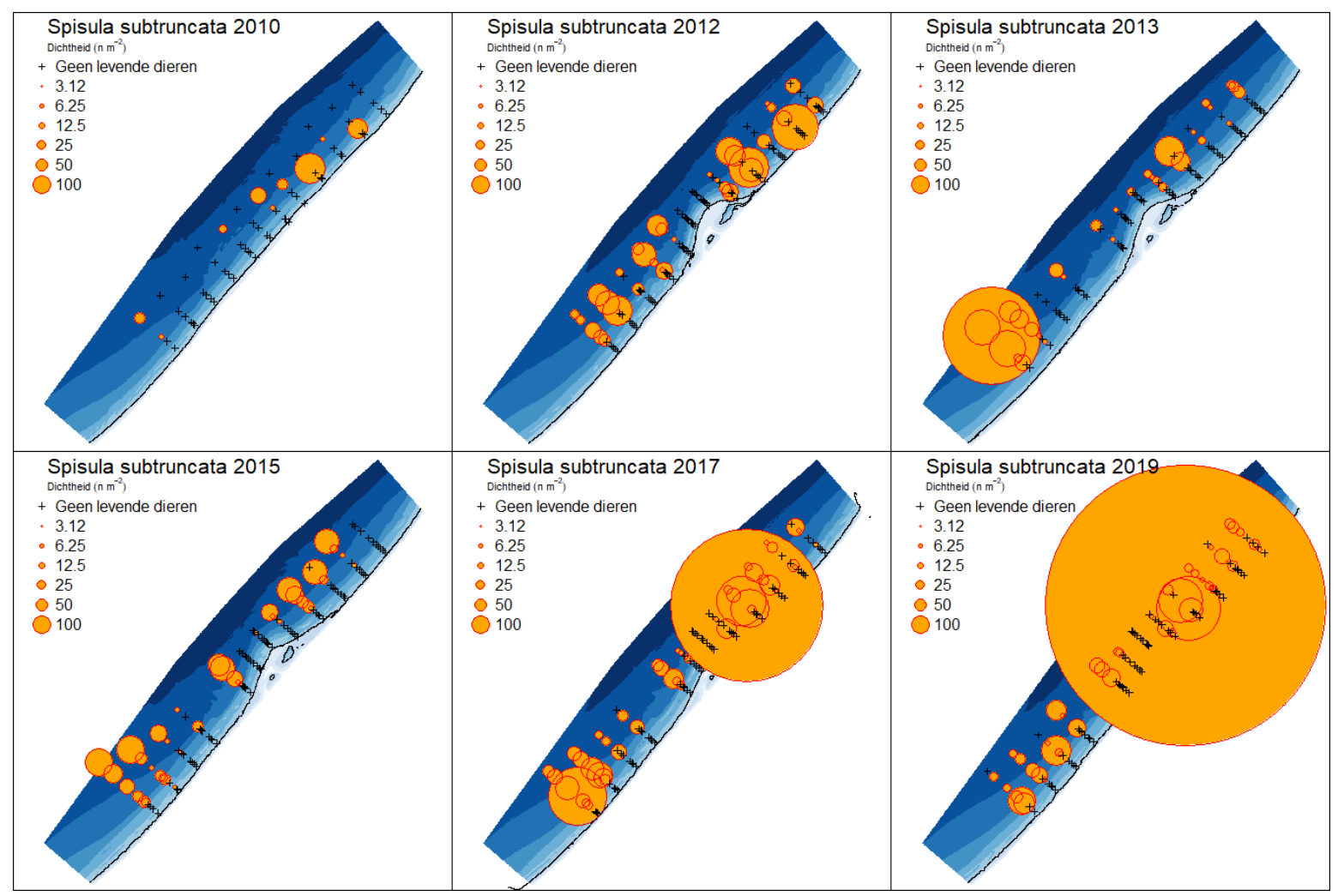

Figuur 82: Verspreidingskaarten Spisula subtruncata in de Van Veen bemonstering over de jaren 2010 tot en met 2019. 


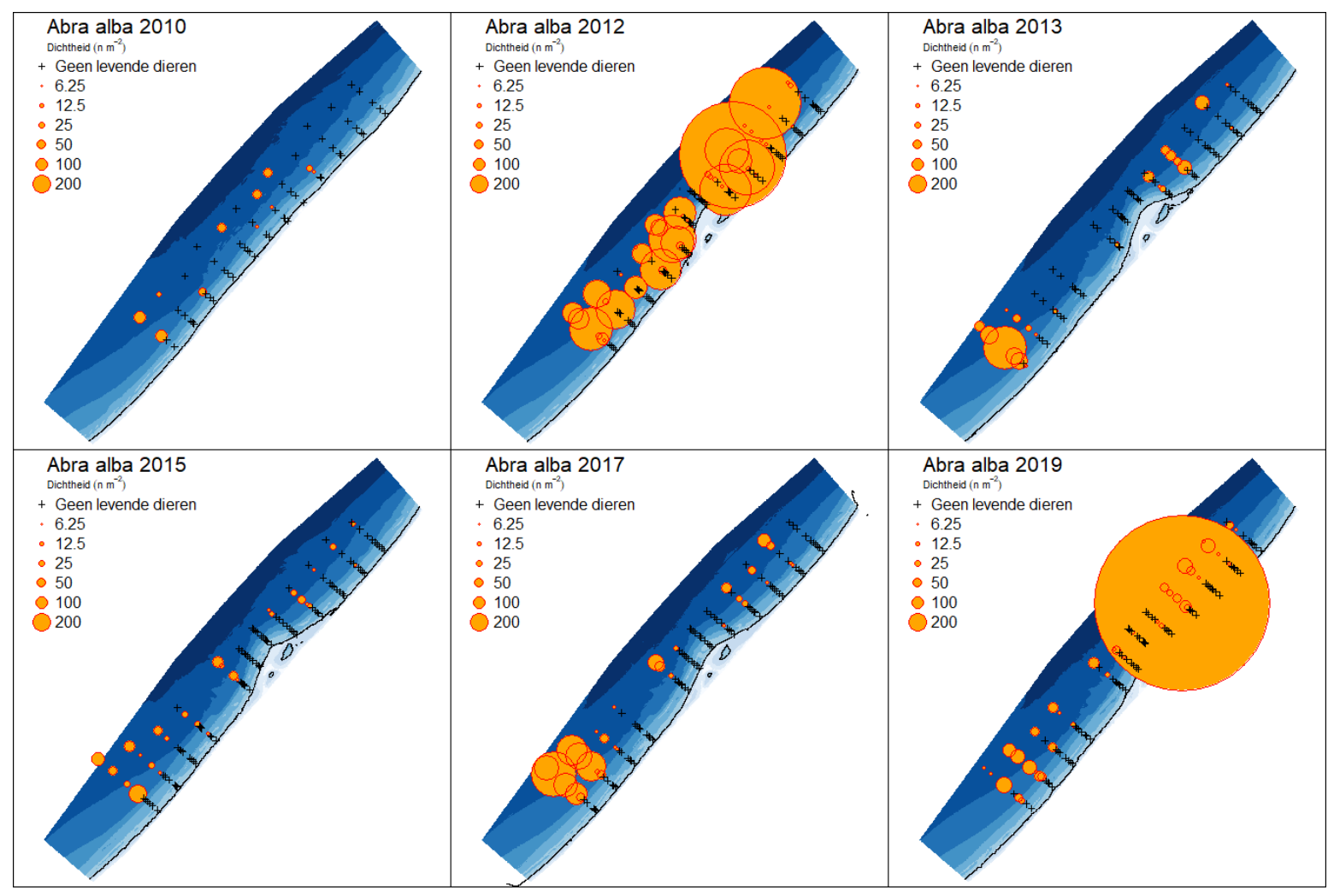

Figuur 83: Verspreidingskaarten Abra alba in de Van Veen bemonstering over de jaren 2010 tot en met 2019.

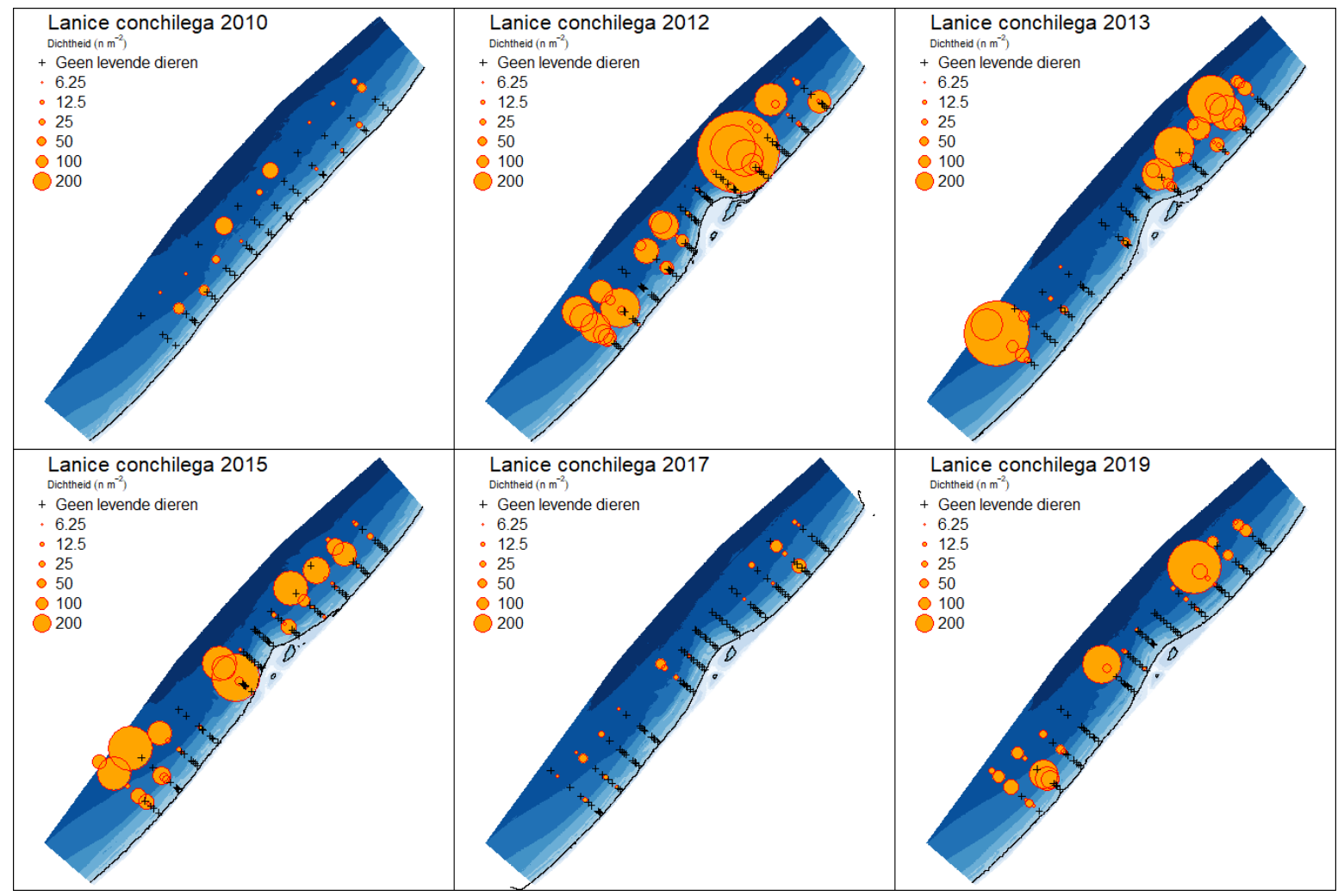

Figuur 84: Verspreidingskaarten Lanice conchilega in de Van Veen bemonstering over de jaren 2010 tot en met 2019. 


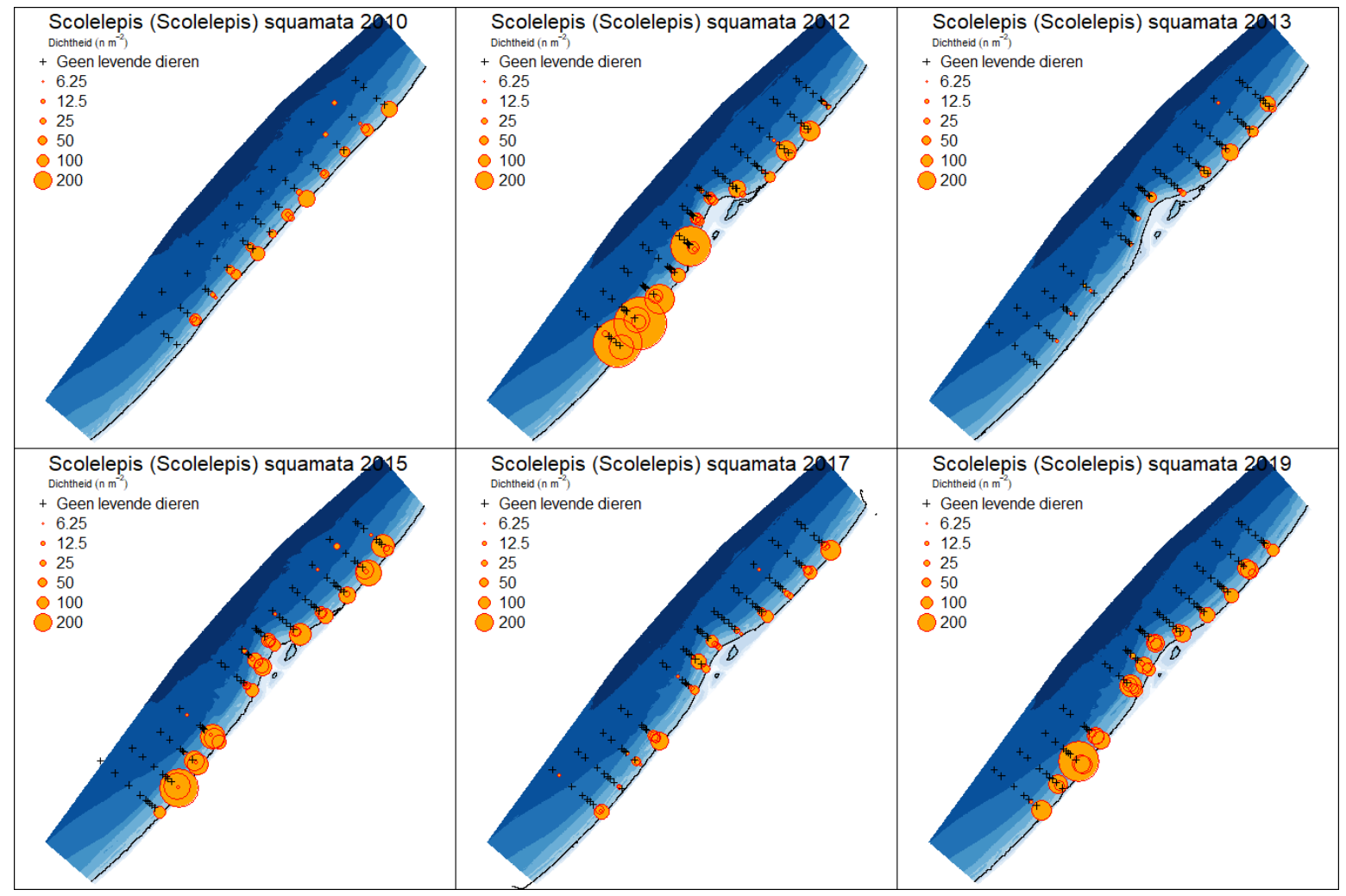

Figuur 85: Verspreidingskaarten Scolelepis (Scolelepis) squamata in de Van Veen bemonstering over de jaren 2010 tot en met 2019.

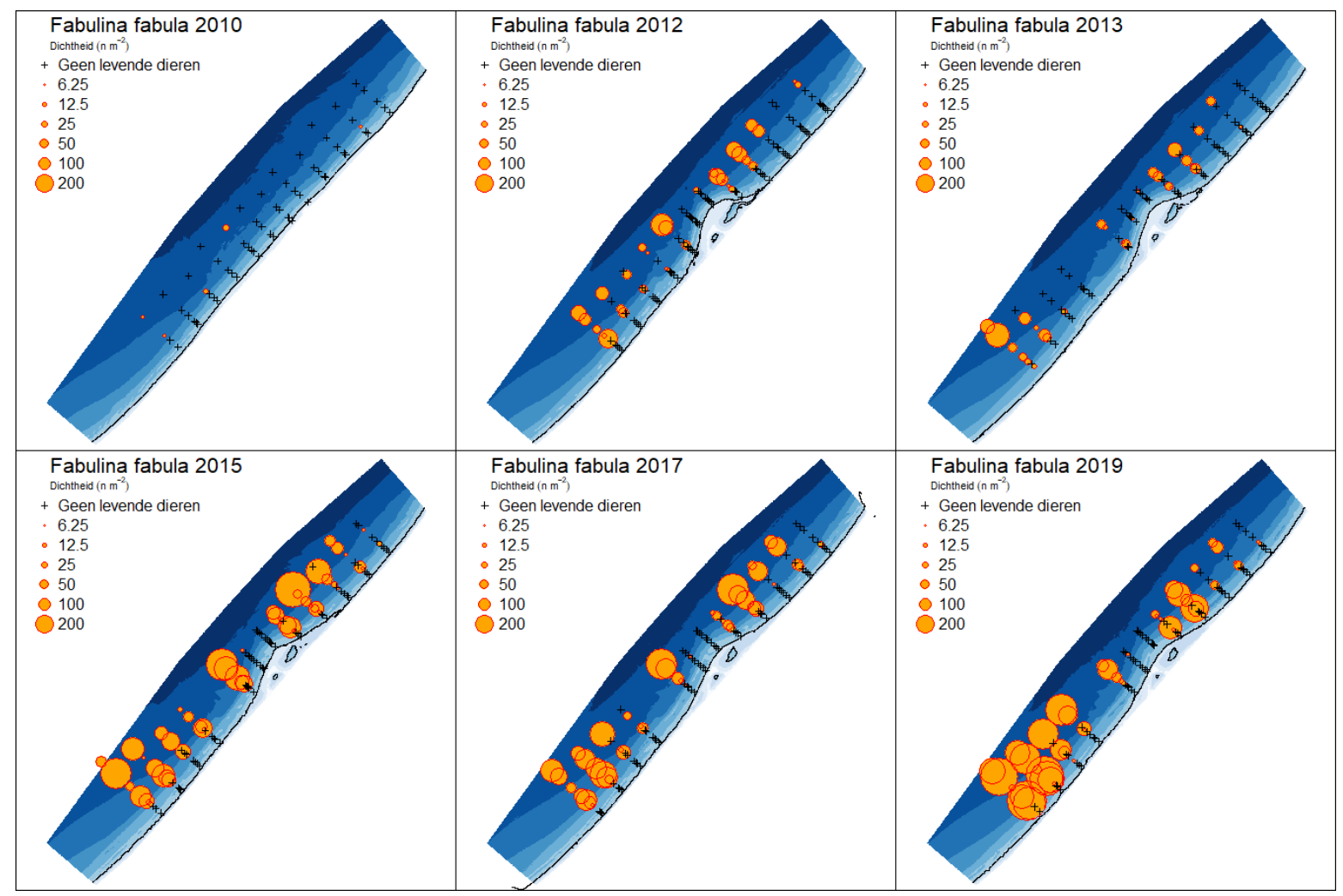

Figuur 86: Verspreidingskaarten Fabulina fabula in de Van Veen bemonstering over de jaren 2010 tot en met 2019. 


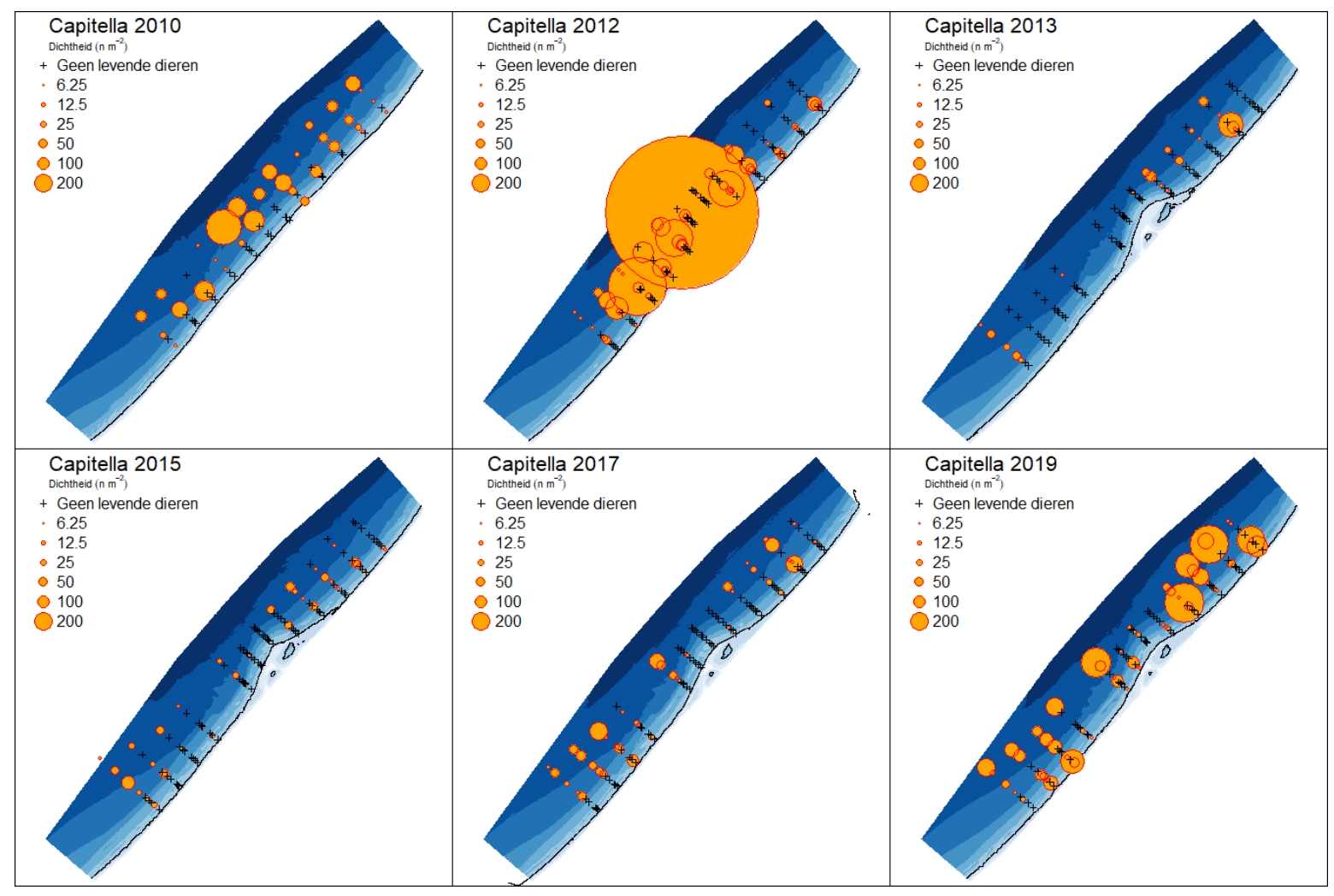

Figuur 87: Verspreidingskaarten Capitella spp. in de Van Veen bemonstering over de jaren 2010 tot en met 2019.

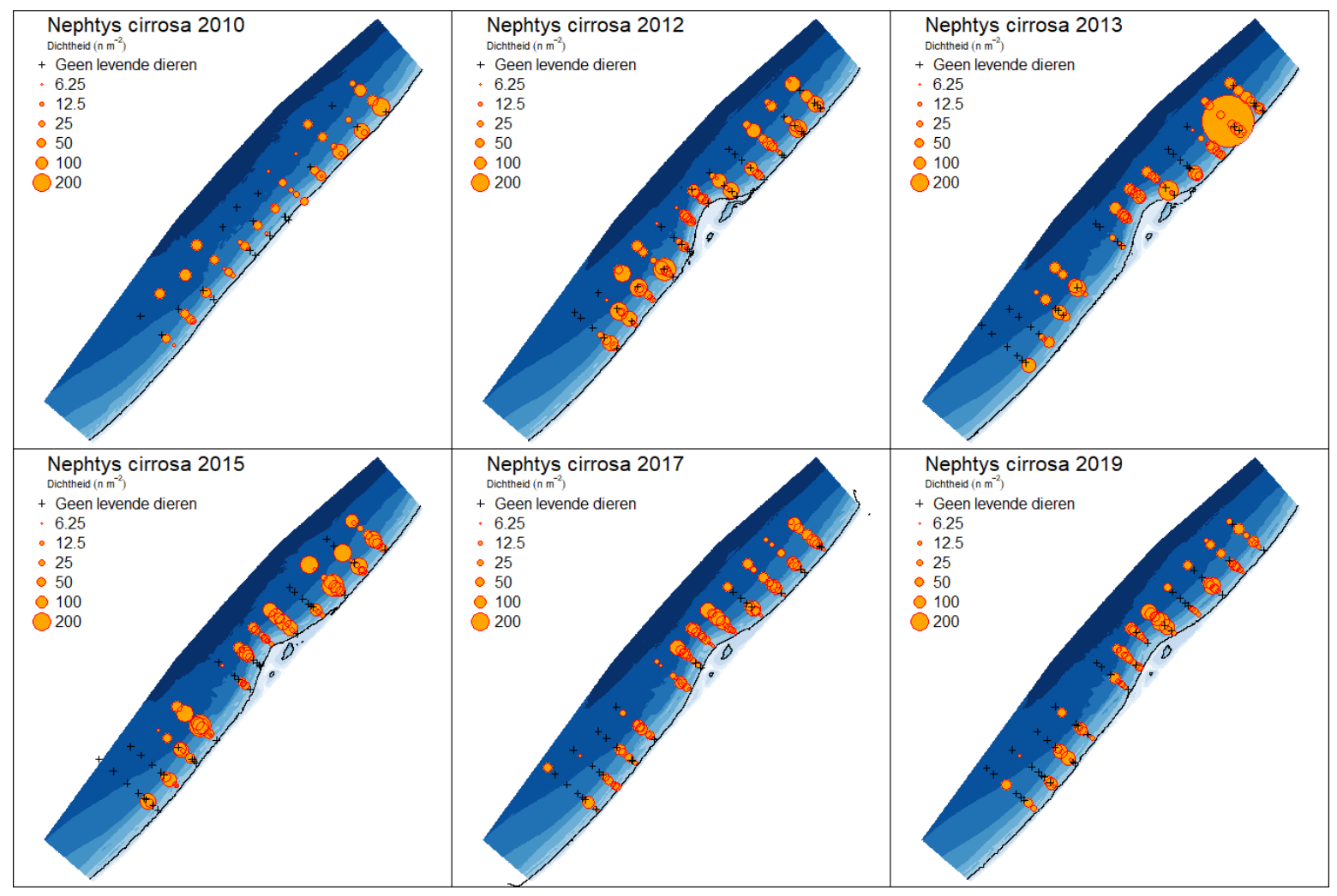

Figuur 88: Verspreidingskaarten Nephtys cirrosa in de Van Veen bemonstering over de jaren 2010 tot en met 2019. 


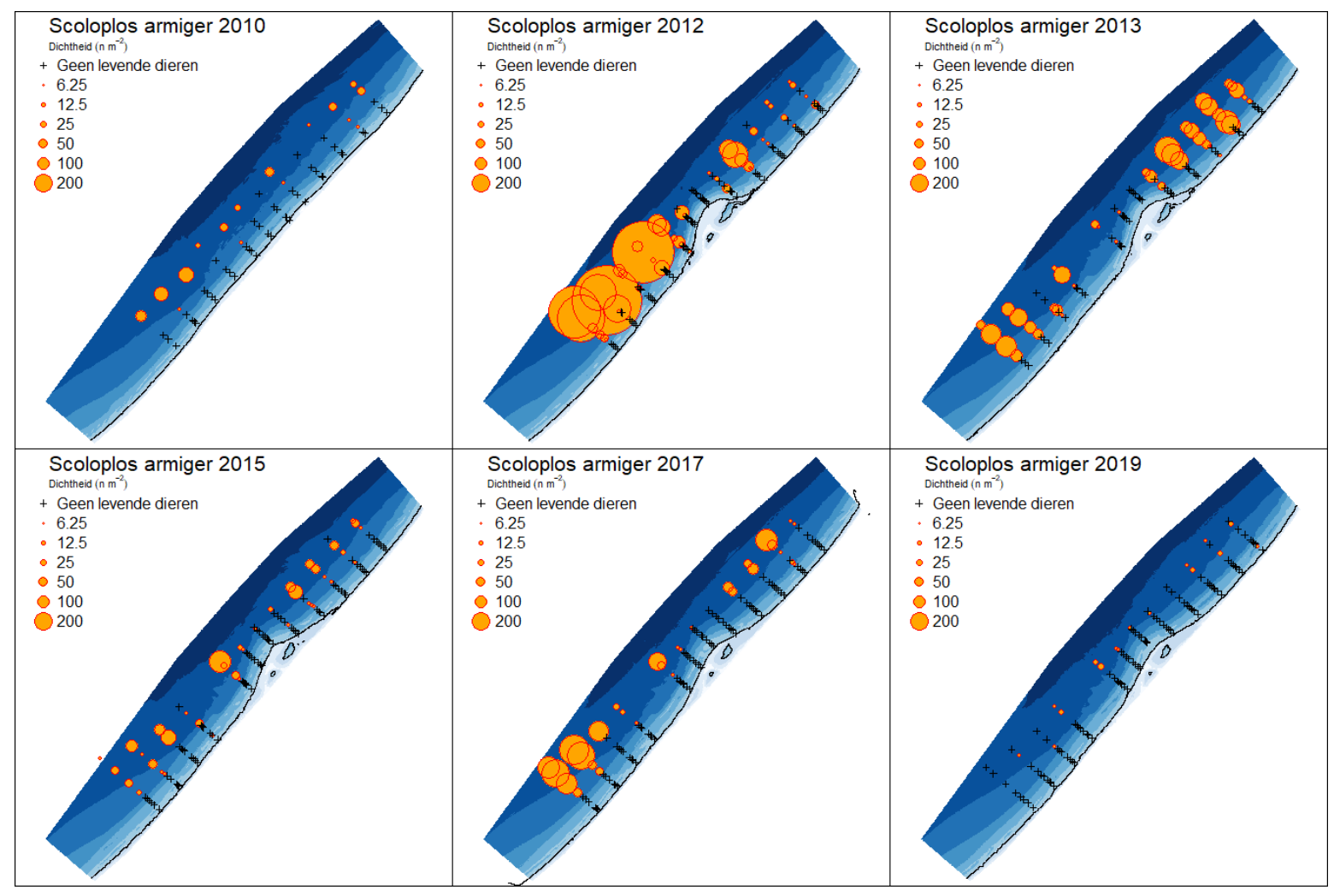

Figuur 89: Verspreidingskaarten Scoloplos armiger in de Van Veen bemonstering over de jaren 2010 tot en met 2019.

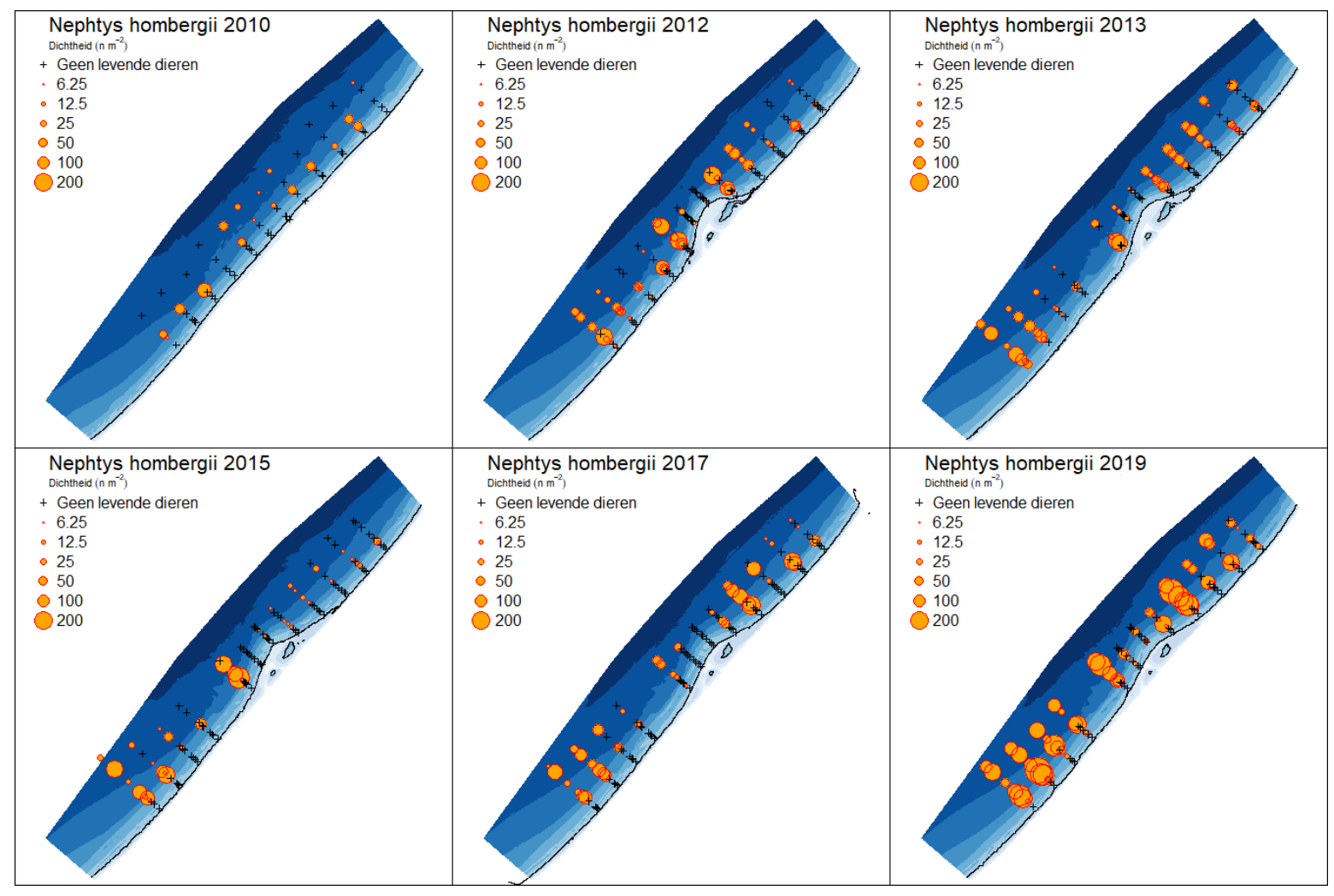

Figuur 90: Verspreidingskaarten Nephtys hombergii in de Van Veen bemonstering over de jaren 2010 tot en met 2019. 


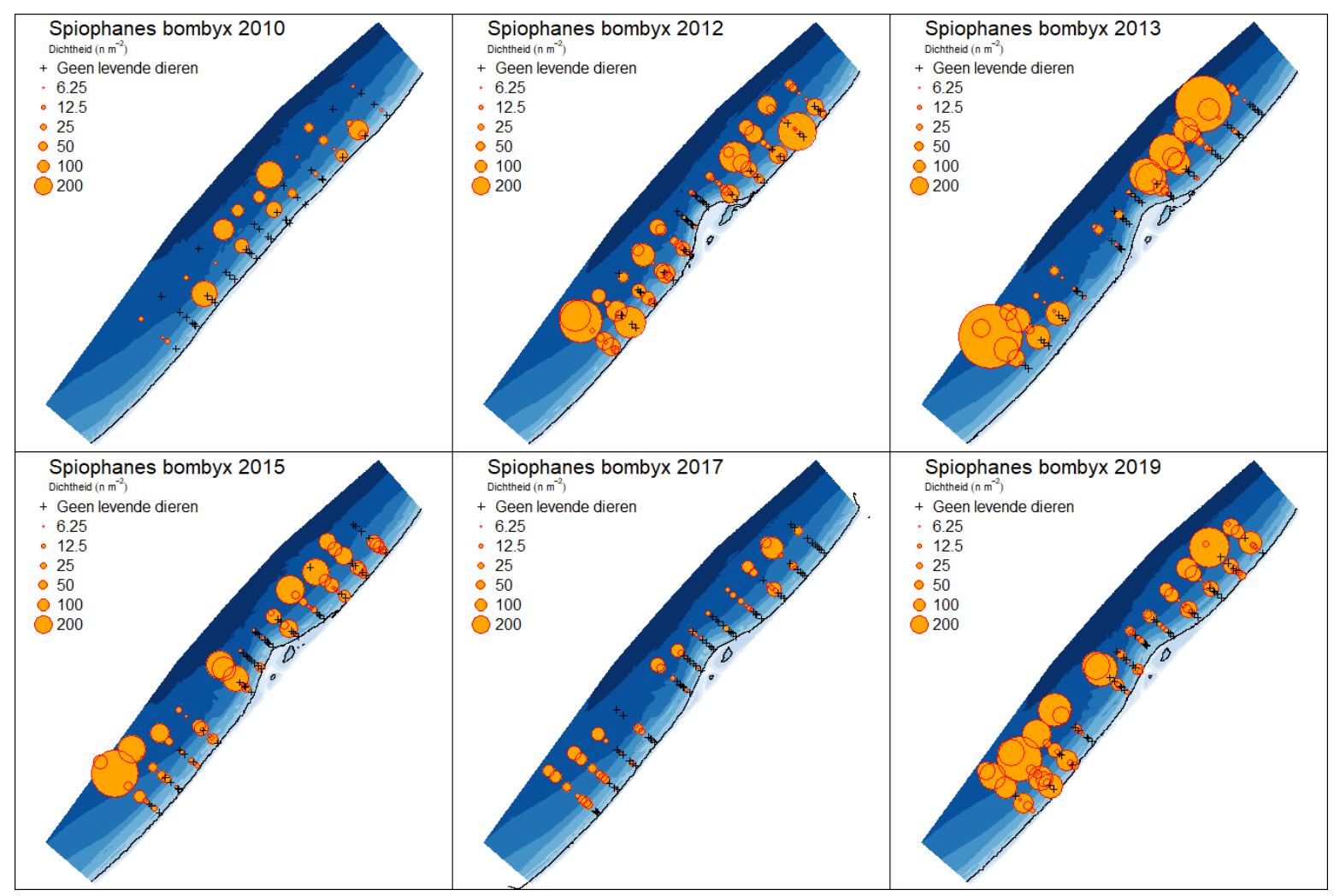

Figuur 91: Verspreidingskaarten Spiophanes bombyx in de Van Veen bemonstering over de jaren 2010 tot en met 2019.

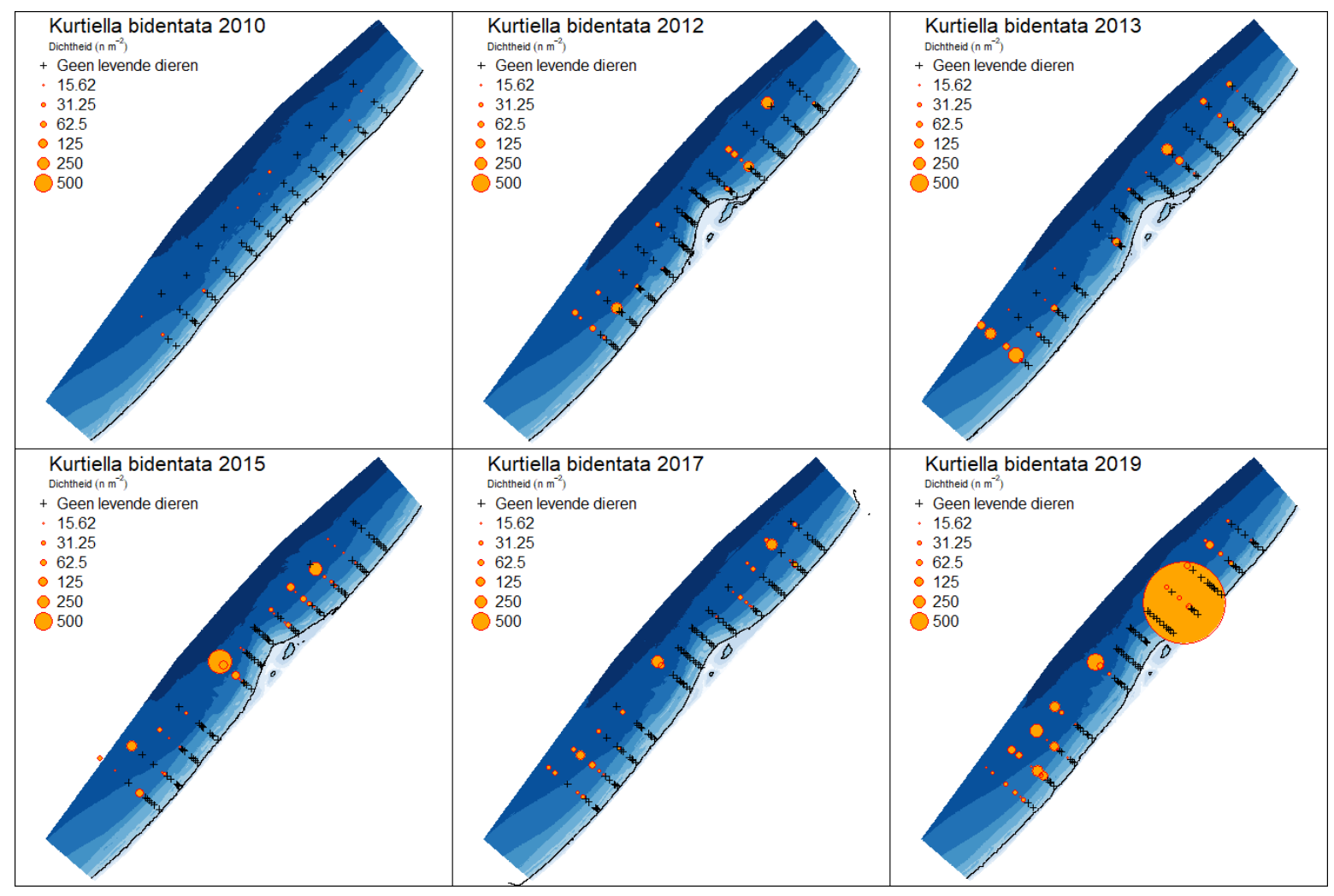

Figuur 92: Verspreidingskaarten Kurtiella bidentata in de Van Veen bemonstering over de jaren 2010 tot en met 2019. 


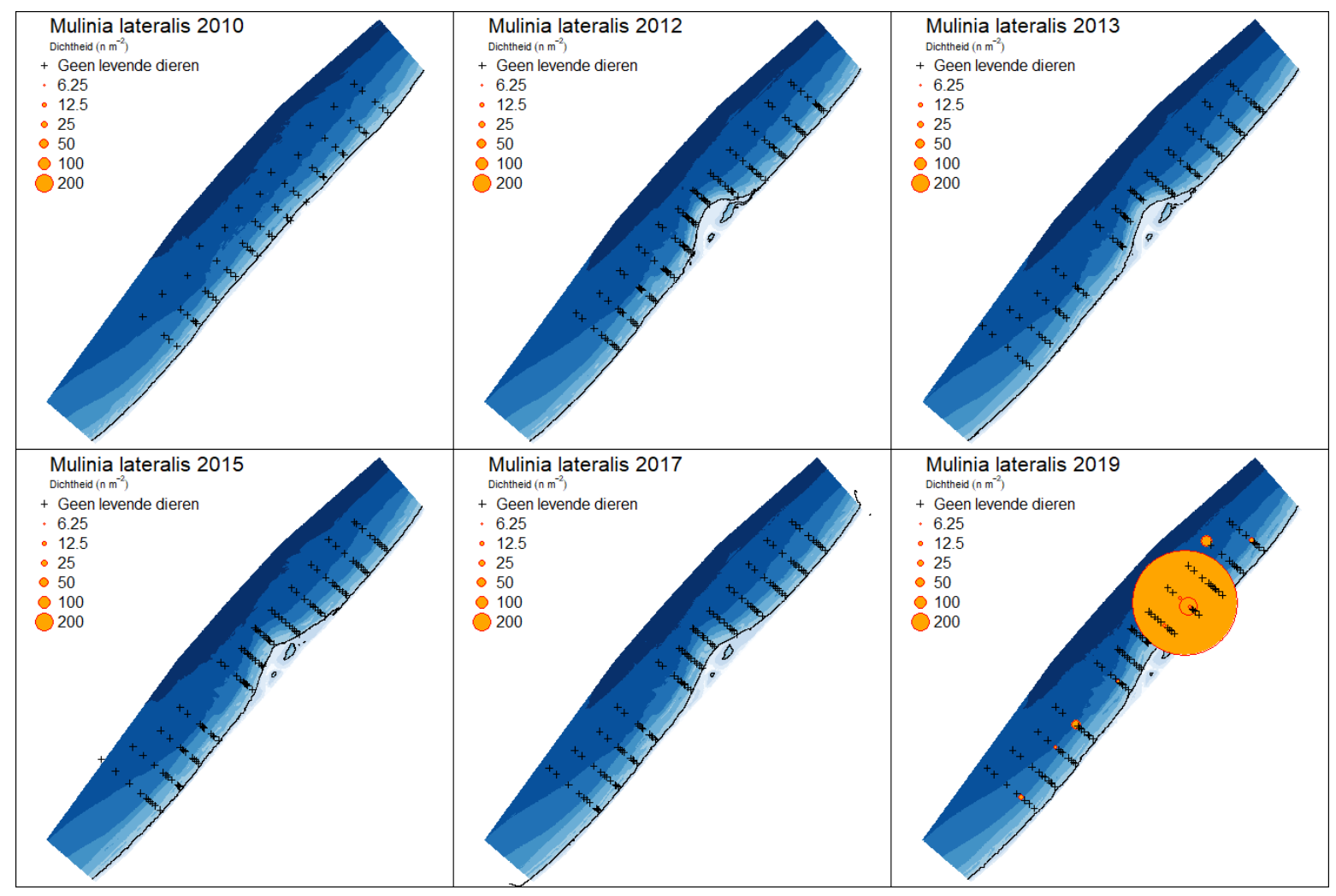

Figuur 93: Verspreidingskaarten Mulinia lateralis in de Van Veen bemonstering over de jaren 2010 tot en met 2019.

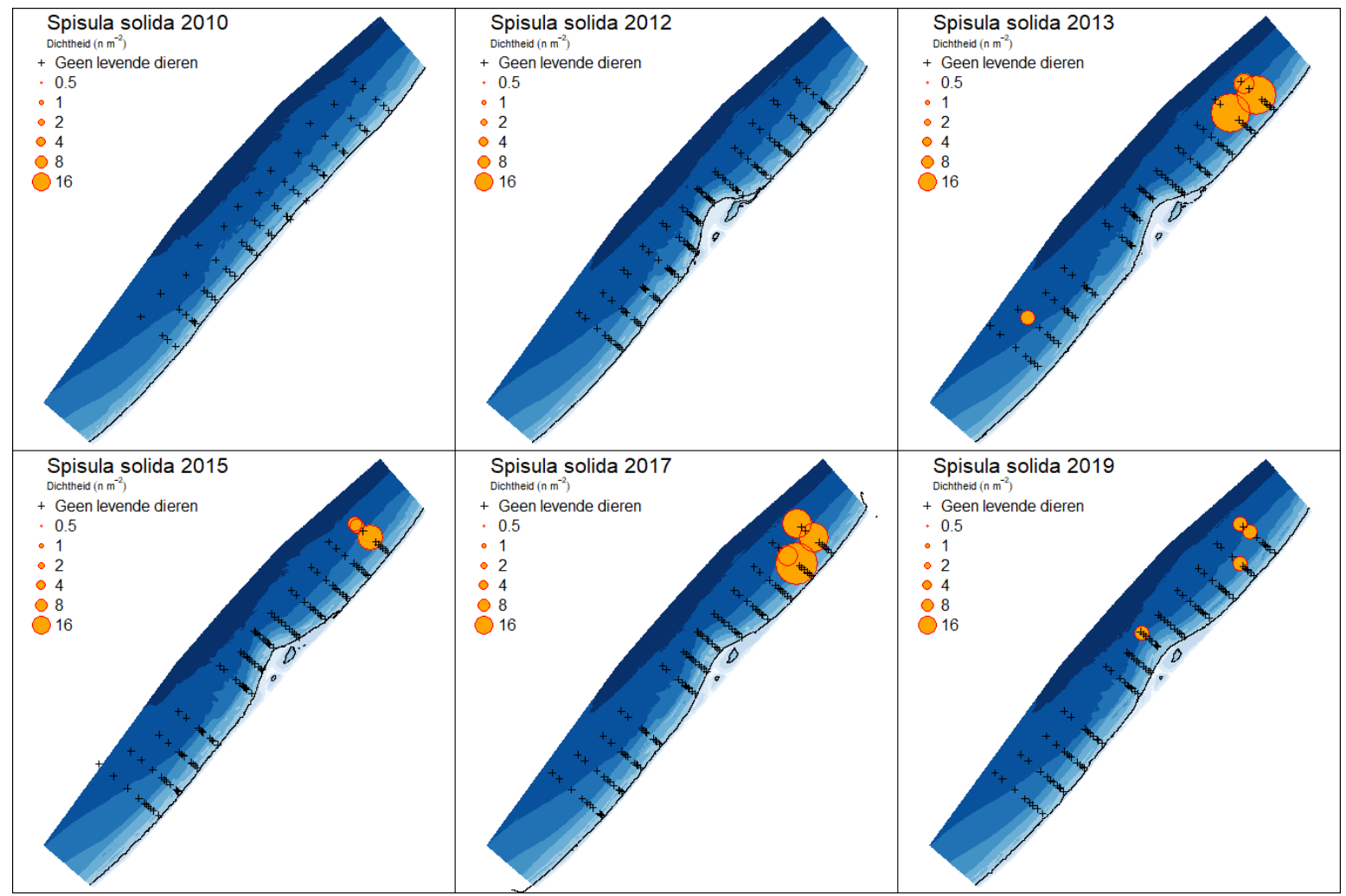

Figuur 94: Verspreidingskaarten Spisula solida in de Van Veen bemonstering over de jaren 2010 tot en met 2019. 
Wageningen Marine Research

T: $+31(0) 317480900$

E: marine-research@wur.nl

www.wur. $\mathrm{nl} /$ marine-research

Bezoekers adres:

- Ankerpark 271781 AG Den Helder

- Korringaweg 7, 4401 NT Yerseke

- Haringkade 1, 1976 CP IJmuiden
Wageningen Marine Research levert met kennis, onafhankelijk wetenschappelijk onderzoek en advies een wezenlijke bijdrage aan een duurzamer, zorgvuldiger beheer, gebruik en bescherming van de natuurlijke rijkdommen in zee-, kust- en zoetwatergebieden. 